S. IDSunomental

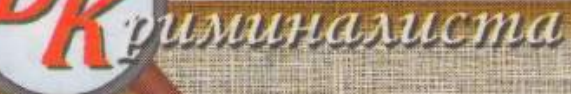

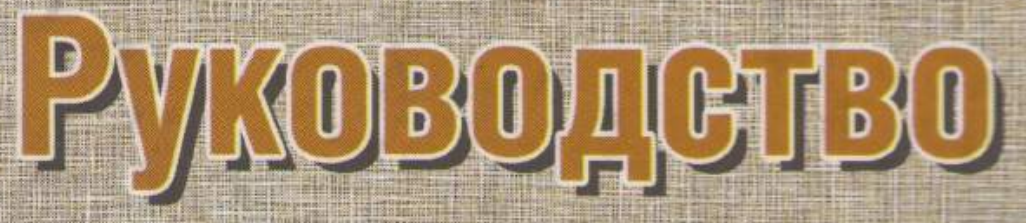

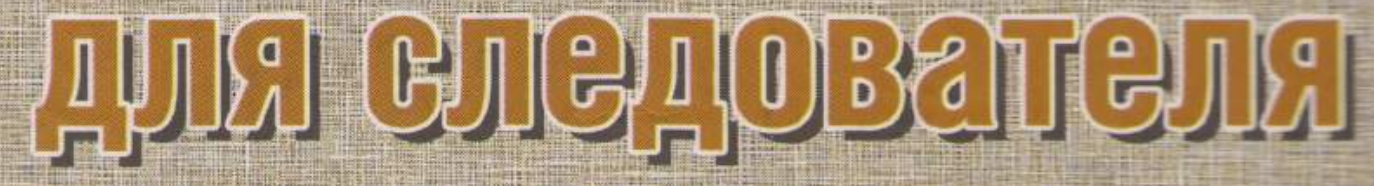

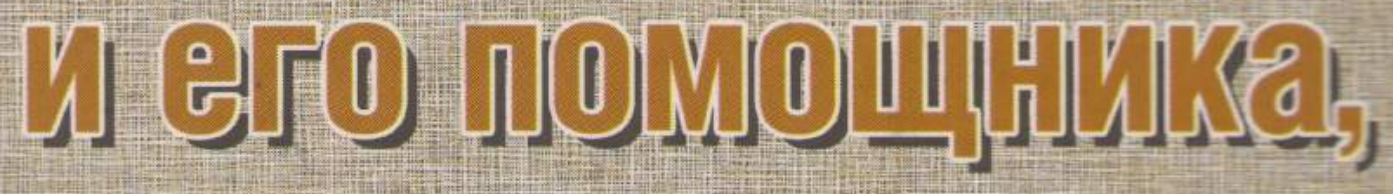

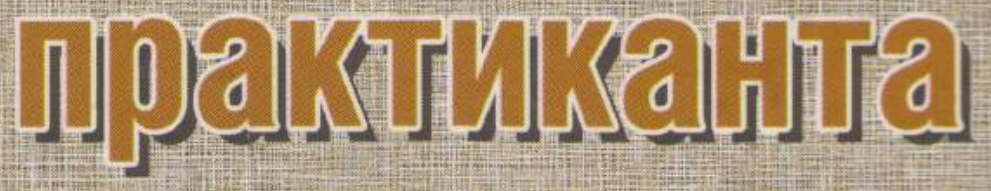$$
\text { - = TR }
$$ 


\section{РУКОВОДСТВО ДЛЯ СЛЕДОВАТЕЛЯ И ЕГО ПОМОЩНИКА, ПРАКТИКАНТА}

\section{Учебно-практическое пособие}

\section{Руководитель авторского коллектива и ответственный редактор - доктор юридических наук Ю.П. Гармаев}

Издательство «Юрлитинформ»

Москва

2009 


\section{Предисловие}

\section{Рецензенты:}

Егоров H.H. - профессор кафедры криминалистики Московской государственной юридической академии имени О.Е. Кутафина, доктор юридических наук;

Лубин А.Ф. - профессор кафедры криминалистики Нижегородской академии МВД России, доктор юридических наук, профессор.

Руководство для следователя и его помощника, практиканта: Учебнопрактическое пособие / Коллектив авторов под общ. ред. Ю.П. Гармаева. М.: Юрлитинформ, 2009. - 208 с.

\section{ISBN 978-5-93295-589-5}

С каждым годом в правоохранительные органы приходит все больше студентов-практикантов и постоянных общественных помощников. Но практические работники часто не знают, как эффективно использовать их труд, передавая при этом свое профессиональное мастерство.

Настоящее Руководство подготовлено коллективом ученых и практиков в рамках инновационного проекта «Прикладные методы обучения юристов», подлержанного грантом Президента РФ. Издание имеет тройное назначение: 1) это памятка для следователя; 2) это совокупность рекомендаций о том, как он может эффективно использовать работу своего общественного помощника и студентов-практикантов; 3) это пособие для самих общественных помощников и практикантов. Например, следователи могут использовать отдельные главы для постановки задач и контроля их исполнения, не тратя лишнее время на обучение и инструктаж.

Адресуется следователям, дознавателям, другим работникам правоохранительных органов, их общественным помощникам, студентам, всем, кто интересуется криминалистикой и уголовным процессом, а так же инновационными методами обучения юристов.

УДК 343.162.1

ББК 67.411

ISBN 978-5-93295-589-5

(C) Коллектив авторов, 2009 (C) Издательство «Юрлитинформ», 2009
В настоящее время и руководство нашей страны, и общественность постоянно обращают внимание на низкое качество обучения в большинстве юридических вузов. Результаты очевидны и чрезвычайно вредны. В частности, невысокий уровень квалификации кадрового состава органов предварительного расследования, куда устремляется значительная часть выпускников-юристов, уже стал притчей во языцех. Профессиональная некомпетентность следователей становиться особенно очевидной в ходе судебного разбирательства по уголовным делам. Вот почему своевременной и необходимой представляется инициатива Президента Российской Федерации, который в своем указе, специально посвященном юридическому образованию, упомянул о необходимости увеличения объема практической части основной образовательной программы высшего профессионального образования ${ }^{1}$.

В этих условиях работодатели нашей страны, в том числе органы предварительного расследования и суда, вправе рассчитывать на то, что со студенческой скамьи будут выходить хорошо подготовленные юристы, знакомые не только с теорией и законодательством, но и с реальной практикой его применения, способные составить любой правоприменительный акт, помочь гражданам подготовить необходимые им документы, защищая их права.

Чтобы повысить качество практической составляющей обучения юристов, необходимы адаптированные к практике учебники и пособия. Именно к таковым относится книга, которую читатель держит в своих руках.

«Руководство для следователей и их помощников, практикантов» является первым в своем роде изданием, содержащим прикладные рекомендации как для следователей, так и студентов в период прохождения ими практик и работы общественными помощниками. Книга подготовлена коллективом опытных практических работников и ученых в рамках инновационного проекта «Прикладные методы обучения юристов», поддержанного грантом Президента РФ. Руководитель авторского коллектива и ответственный редактор - доктор юридических наук, профессор Ю.П. Гармаев 14 лет отдал службе в органах и учреждениях прокуратуры Российской Федерации, в том числе 5 лет трудился в

${ }^{1}$ Пункт 1 б Указа Президента Российской Федерации от 26.05.2009 № 599 «О мерах по совершенствованию высшего юридического образования в Российской Федерации» // Российская газета. 2009. 29 мая. № 97 (4921). С. 13. 
Иркутском институте повышения квалификации прокурорских работников Генеральной прокуратуры РФ. Опыт обучения и практических работников, и студентов, проведение выездных занятий в правоохранительных органах в 22 субъектах Российской Федерации - все это в совокупности позволило организовать разработку и успешно апробировать прикладные и притом не имеющие аналогов в России средства обучения.

В частности, авторы сделали в «Руководстве...» соответствующие ссылки, подготовили и разместили в Интернете для открытого пользования электронные документы - образцы и примеры процессуальных и иных документов для обучения начинающих следователей, общественных помощников и практикантов. Такой подход, безусловно, повысит практическую значимость и эффективность предлагаемых в книге рекомендаций.

Есть основания полагать, что при условии широкого внедрения настоящего «Руководства...», качество и эффективность расследования уголовных дел может улучшиться и в то же время будет повышен уровень прикладных знаний и навыков выпускников юридических вузов, больше квалифицированных молодых специалистов успешно трудоустроятся и с полной отдачей будут работать в правоохранительных и судебных органах нашей страны.

A.О. Хориноев, заслуженный юрист РФ председатель Верховного суда Республики Бурятия, кандидат юридических наук

\section{Глава 1}

\section{КОМУ И КАК ПОЛЬЗОВАТЬСЯ ЭТИМ РУКОВОДСТВОМ}

\section{1. Обращение к следователям и руководителям следственных органов}

Уважаемые следователи²! Перед вами пособие, призванное существенно сократить затраты времени и сил в профессиональной деятельности. Прежде всего оно адресовано следователям, имеющим небольшой опыт работы. Это памятка о том, как, начиная свою трудовую деятельность, не допустить ошибок и нарушений закона в самых, казалось бы, простых, но весьма насущных вопросах предварительного расследования: систематизация материалов дела и электронных баз данных, организация осмотра места происшествия, других следственных действий, составление процессуальных документов и т.п.

Есть у пособия и другие задачи, и речь уже не только о начинающих следователях

Уважаемые коллеги! Всю свою работу в уголовном судопроизводстве вы привыкли делать самостоятельно, не надеясь, а порой и не доверяя посторонней помощи. И это, конечно же, неплохо. Но... Всегда ли это эффективно?

Между тем в системе органов прокуратуры РФ произошло не самое заметное, но весьма знаменательное событие. Приказом первого заместителя Генерального прокурора Российской Федерации - председателя Следственного комитета при прокуратуре Российской Федераиии № 50 от 15.05.2008 было утверждено «Положение об общественном помощнике следователя Следственного комитета при прокуратуре Российской Федерации» ${ }^{3}$. Как гласит положение, институт общественного помощника следователя призван содействовать привлечению граждан к работе по противодействию преступности, созданию условий для формирования кадрового резерва (п. 2). Итак, сделано главное - впервые начато формирование правовых основ деятельности общественного помощника

2 Здесь и далее под термином «следователь» подразумеваются следующие должностные лица: следователь, дознаватель, следователь-криминалист, руководитель следственного органа, начальник органа дознания.

${ }^{3}$ См. Приложение 1. Далее - «Положение» или «Положение об общественном помощнике следователя». 
следователя, определены его права и обязанности, сделан важный шаг в плане мотивации его работы - он может попасть в кадровый резерв следственных органов.

Теперь каждый или почти каждый следователь следственного органа Следственного комитета при прокуратуре РФ в порядке, установленном Положением, может быть обеспечен общественным помощником. Только какую же работу ему доверить, какие поручения дать, что собственно с ним делать - неумелым да и не всегда знающим, а потому неуверенным в себе молодым человеком?!

Пункт 18 названного Положения определяет лишь самые общие направления деятельности общественного помощника:

1) техническая, информационная и организационная помощь следователю в его работе;

2) подготовка проектов документов по поручению следователя.

Вряд ли этот перечень вносит полную ясность. Обозначенные направления деятельности требуют конкретизации, но уже не на уровне ведомственного нормативного акта, а на уровне методических рекомендаций

Вероятно первое, что приходит в голову следователю - поручить помощнику разнести повестки, использовать его в качестве понятого 4 и т.п. Чтобы доверить им что-то более серьезное и квалифицированное, например, составить проект обвинения ${ }^{5}$, следователю недостаточно быть просто профессионалом, нужно иметь еще и опыт наставника. Но не у всех он есть, как собственно и время для работы с молодежью.

Но проблема обеспечения работой общественного помощника - это еще полбеды. Ведь почти постоянно в следственный отдел (отделение) приходит большое количество студентов-практикантов. С ними еще сложнее - занимают много места в тесном помешение, «путаются под ногами», задают наивные вопросы... в общем, создают дополнительные хлопоты. А у вас их и так... Многие следователи просто не знают, чем занять практикантов. Да и приходят студенты чаще всего только на 2-4 недели. Чему их можно научить за это время, - скажете вы?! Только чемуто научишь, а они уже назад - в аудитории. Какой же от них толк?!

Как показал практический и дидактический опыт коллектива авторов этого руководства, не только постоянно действующие обще-

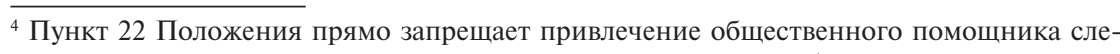
дователя в качестве участника уголовного судопроизводства (эксперта, специалиста, переводчика, понятого). См. гл. 5 .

${ }^{5}$ См. гл. 14. ственные помощники, но даже и студенты-практиканты могут оказать ощутимую помощь следствию даже за короткий промежуток времени. Нужно только правильно направить и организовать их работу, пустить их творческую энергию в нужное русло и, наконец, с облегчением ощутить, как много времени сэкономлено, как много полезных дел сделано руками пусть неопытными, но старательными.

Изучив данное руководство, вы можете просто и без лишних затрат на инструктаж распределить работу между общественными помощниками и практикантами, выбрав из текста те главы-задачи, которые более всего вам нужно выполнить на текущий момент досудебного производства по уголовному делу. Мы уверены, что большинство общественных помощников и практикантов, получив эти задания, наконец-то почувствуют, что они реально востребованы и полезны своим старшим товарищам. Вы сами увидите, как радость творчества, энтузиазм, чувство собственной значимости зажжет огонь в глазах молодежи, и вместо равнодушного статиста вы получите настоящего Помощника, а далее, быть может, и своего коллегу.

Перед тем, как приступить к конкретным рекомендациям, просим вас изучить и учесть некоторые особенности личности типичных практикантов-юристов и общественных помощников.

1. Добросовестный практикант - студент-практикант, имеющий хороший первичный образовательный уровень и пришедший на практику с твердым намерением научиться чему-либо новому, не считаясь с личным временем и объемом усилий.

Добросовестного практиканта желательно поднять до уровня общественного помошника (см. ниже). Рекомендуется для начала поручать задачи невысокого уровня сложности, например, изложенные в главах $2-9$, но готовить к выполнению задач (см. главы 10-15).

2. Общественный помощник - это элита, «гвардия» молодых юристов. Как правило, это в прошлом добросовестный практикант (п. 1), который по зову сердца, а не ради простого любопытства, доходов, престижа и т.п. желает быть для начала общественным помощником, поскольку в будущем собирается претендовать на должность следователя. Ясно, что такой молодой человек или девушка хорошо мотивированы, поскольку правомерно надеятся, что работа общественного помощника, во-первых, позволит им ближе познать практику уголовного судопроизводства, во-вторых, даст серьезные конкурентные преимущества при трудоустройстве ${ }^{6}$. Трудится такой человек добровольно и безвозмездно,

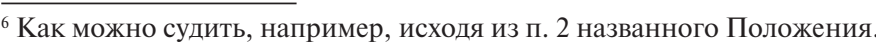


не считается с личным временем, отличается творческим мышлением, высокой работоспособностью, вежливостью и предупредительностью по отношению к руководителю и коллективу органа.

Рекомендуется поручать задачи любого уровня сложности, например, изложенные в главах 10-15. Разумеется советуем присмотреться к нему как к будущему коллеге, сослуживцу. Быть может, в дальнейшем стоит ходатайствовать перед руководством о принятии его на должность следователя.

3. Недобросовестный практикант - студент-практикант, имеющий любой образовательный уровень, но проходящий практику исключительно по необходимости, «для галочки», например для того, чтобы только подписать дневник и другие отчетные документы. Опаздывает, плохо выполняет поручения, часто отпрашивается, «спит на ходу».

Недобросовестным практикантам рекомендуем не поручать ничего. Практика такого лица по вашему усмотрению может быть прекращена досрочно с направлением письма руководству факультета, вуза, на основании которого он может быть отчислен как не прошедший практику. Проект письма и другие материалы к книге размещены на сайте labatr.bsu.ru, электронные приложения к настоящему пособию, папка «Методические материалы».

В основу «Руководства...» положены результаты изучения материалов свыше 3000 уголовных дел различных категорий и свыше 1000 материалов об отказе в возбуждении уголовного дела. Авторами было опрошено и анкетировано более 200 респондентов (следователи, прокуроры, их заместители и помощники из 36 субъектов РФ со стажем работы от трех лет и более), имеющих следственный опыт, опыт поддержания государственного обвинения. Кроме того, респондентам задавались следующие вопросы:

- по каким конкретно задачам привлечение обшественных помошников и практикантов было бы наиболее рациональным, эффективным и при этом законным;

- какие советы наиболее полезны для практических работников и их помощников - практикантов;

- каким языком, каким стилем излагать те или иные рекомендации;

- какого придерживаться объема изложения по отдельным вопросам с тем, чтобы книга не пылилась на полке, а оказывала бы реальную помощь.

Именно на результаты этого опроса, прежде всего, ориентировался авторский коллектив настоящего издания.
$* * *$

Авторы выражают глубокую признательность руководству и коллективам следственных управлений Следственного комитета при прокуратуре РФ, следственных управлений Следственного комитета при МВД России, а также прокуратур следующих субъектов РФ: республик Бурятия и Кабардино-Балкария, Алтайского, Забайкальского, Краснодарского, Красноярского, Приморского, Хабаровского краев, Иркутской, Новосибирской, Омской, Сахалинской, Свердловской, Тюменской, Челябинской областей за апробирование рекомендаций, активную помощь в сборе и обобщении данных практики.

\section{2. Вопросы предупреждения противодействия и сохранения тайны предварительного расследования}

Уважаемые следователи и прокуроры! Искренне полагаем, что большинство общественных помощников и практикантов - это честные и порядочные молодые люди. Однако, как и все прочие граждане, они бывают разными. К сожалению, ни вуз, ни родители не могут гарантировать, что вы не столкнетесь с отдельными проявлениями нечестности, недобросовестности, непорядочности или заинтересованности в исходе конкретного дела.

Следует иметь в виду, что некоторые ограничения устанавливает Положение об общественном помощнике следователя. В частности, таковым может стать только лицо:

- в отношении которого не осуществляется (не осуществлялось) уголовное преследование (за исключением случаев прекращения уголовного дела (уголовного преследования) по реабилитирующим основаниям;

- которое не привлекается (не привлекалось) к административной ответственности (в зависимости от конкретных обстоятельств административного правонарушения данный факт может быть признан не являющемся препятствием для назначения лица общественным помощником следователя или основанием для прекращения его полномочий);

- годное не только по состоянию здоровья, но и по моральным, деловым качествам к осуществлению деятельности в качестве общественного помощника следователя, имеющее склонность к следственной работе (п. 4 Положения). 
Кроме того, общественный помощник следователя обязан оперативно информировать следователя и руководителя следственного органа о проблемах, возникающих при осуществлении им своих полномочий, в том числе о привлечении к уголовной или административной ответственности либо иных обстоятельствах, препятствующих исполнению полномочий общественного помощника следователя (п. 19 Положения).

Общественный помощник несет ответственность за достоверность предоставленной информации, качество и своевременность выполнения обязанностей, возложенных на него настоящим Положением, а также ущерб, причиненный в результате его неправомерных действий следственному органу либо правам и законным интересам граждан и организаций (п. 20 Положения).

Общественный помощник следователя не может быть допущен к работе с документами, содержащими государственную тайну и служебную информацию ограниченного пользования, ему запрещается разглашать сведения, ставшие известными в процессе выполнения поручений следователя по уголовному делу (п. 23 Положения).

Общественному помощнику следователя запрещаемся лично или через других лиц получать от физических и юридических лиц какоелибо вознаграждение (денежные средства, подарки, услуги, оплата развлечений, отдыха, транспортных расходов и прочее) в связи с исполнением обязанностей общественного помощника следователя, а также использовать полномочия общественного помощника следователя в личных целях (п. 24 Положения).

Полагаем, что все эти требования можно и нужно распространять и на практикантов. Следует внимательно относиться к выбору поручаемых задач. Тщательно проверяйте все результаты работы, которую поручаете общественному помощнику или практиканту. Например, то же самое Положение (п. 21) требует от обшественного помошника следователя ежеквартально к 10 числу месяца, следуюшего за истекшим кварталом, готовить письменную информацию о проделанной работе, которая согласовывается со следователем и утверждается руководителем следственного органа, в котором осуществляется деятельность обшественного помошника следователя.

В соответствии с п. 8 Положения кадровое подразделение следственного управления проводит дополнительную проверку сведений о кандидате в общественные помощники следователя, а при необходимости о его ближайших родственниках, в том числе сведений о судимости и привлечении лица к административной ответственности.
Вместе с этим с учетом ситуации по конкретным делам и материалам рекомендуем в пределах ваших служебных полномочий проверить, чем, помимо учебы и поручаемой работы (практики), занимается молодой человек; каков круг его знакомств; возможно ли оказание на него нежелательного воздействия от представителей стороны зашиты, например, исключено ли совершение им действий, направленных на уничтожение либо фальсификацию доказательств и т. д. Хоть и очень редко, но, к сожалению, негативные примеры в следственной практике имеются.

Как правильно отмечено в п. 23 Положения, далеко не всегда необходимо давать практиканту всю информацию по конкретному делу, находящемуся в производстве. Следует строго и тщательно разъяснить помощнику (практиканту) недопустимость разглашения сведений, ставших ему известными в процессе выполнения поручений следователя по уголовному делу, напомнить ему об уголовной ответственности за воспрепятствование осуществлению правосудия и производству предварительного расследования (ст. 294 УК РФ).

Убедившись в порядочности, добросовестности общественного помощника (практиканта), установив оптимальный уровень контроля за его деятельностью, можно приступить к конкретным поручениям, изложенным ниже.

\section{3. Обращение к общественным помощникам и практикантам}

Уважаемые общественные помощники и практиканты! Вы порой просто не представляете себе, как бывает загружен работой следователь, дознаватель и другие наши коллеги - правоприменители!

В существующем режиме работы, порой почти нечеловеческом по своему напряжению, даже высококлассному специалисту очень трудно избежать отдельных упушений: допустить ошибку при составлении сложного процессуального документа (см. гл. 9, 14), забыть приобщить к делу важный материал (см. гл. 15), не взять на место происшествия нужный бланк или предмет (см. гл. 3) и т.п.

Согласитесь, все это по-человечески понятно и не означает, что специалист не компетентен. Как известно, не ошибается тот, кто не работает. При этом в уголовном судопроизводстве существует масса задач и процедур, не сложных по своему содержанию, но затратных по времени выполнения. Например, любому следователю необходимо регулярно систематизировать и подшивать все дела и материалы, нахо- 
дящиеся у него в производстве (см. гл. 2). Но времени не хватает да и жалко. И тут на помощь можете прийти вы - наши добросовестные и умелые молодые коллеги!

А теперь представьте, насколько приятно будет практическому работнику, если вы вдумчиво, со знанием дела и корректно поможете старшему товарищу. Вы точно заслужите, быть может, не очень явную, но весьма глубокую благодарность профессионала, с удовольствием обнаружившего, что рядом с ним не просто «статист», «разносчик повесток», а подающий большие надежды молодой специалист, внимательный, знающий, работоспособный и доброжелательный, в общем как раз тот, кого он хотел бы видеть рядом как коллегу, соседа по кабинету. И кто знает, быть может, именно его вовремя «замолвленное словечко» или мотивированный рапорт будет решающим при вашем трудоустройстве. Хотите научиться оказывать квалифицированную помощь практическому работнику читайте это пособие

\section{Внимание!}

Перед дальнейшим изучением «Руководства...» обязательно прочитайте предыдущий параграф «Вопросы предупреждения противодействия и сохранения тайны предварительного расследования». Согласуйте с курирующим следователем и руководителем следственного органа все обозначенные вопросы.

Книга, которую вы держите в руках, не подменяет собой другую учебную литературу. Выходя на практику или работу в должности общественного помощника, следует, прежде всего, ориентироваться на учебные издания по криминалистике, уголовному процессу, уголовному праву и другим предметам «криминального цикла», постоянно обращаться к ним в своей работе.

\section{4. Где скачать и как работать с электронными приложениями}

В процессе работы над данным руководством перед авторами стояла задача сделать его максимально прикладным. А для этого мало только давать советы. Нужно предоставить возможность начинающим следователям, их помощникам и практикантам здесь же применить совет на практике. А это, как правило, означает составить процессуальный или иной документ. С тех пор как в правоохранительных органах появилась компьютерная техника, это делается на основе разнообразных элект- ронных шаблонов, которые тысячами оседают в персональных компьютерах и локальных сетях каждого следственного подразделения. Есть у таких подходов и свои минусы (см. 6.7). Но и совсем отходить от сложившейся практики тоже не выход.

Поэтому авторы решили подготовить и разместить в Интернете для открытого пользования электронные документы - образцы и примеры процессуальных и иных документов для обучения начинающих следователей, обшественных помощников и практикантов. Для этого после специальной выборки материалов уголовных дел некоторые процессуальные и оперативно-розыскные документы были отсканированы, отредактированы и обезличены.

Указанные электронные документы с высокой долей условности обозначены тремя наименованиями:

- «образцы» - документы, которые, по мнению авторов, составлены правильно, без ошибок и нарушений закона и потому могут служить в качестве ориентиров для обучаемых. Однако не следует забывать, что, во-первых, автор-составитель документа может ошибаться, вовторых, в каждом регионе, населенном пункте, имеются оригинальные подходы к содержанию тех или иных документов, отступление от которых отдельными правоприменителями признается ошибкой, нарушением закона. Поэтому даже образец документа, не говоря уже о примерах, следует согласовывать, прежде всего, с руководителем следственного органа, судьями региона;

- «nримеры»- документы, оставленные в авторской редакции их составителей - практических работников. Они не свободны от недостатков, ошибок и даже, вероятно, нарушений закона. Однако такова реальная правоприменительная практика и ее необходимо знать и изучать. К тому же соответствующие уголовные дела, как правило, завершались успехом стороны обвинения. Это означает, что либо вероятные ошибки и нарушения были устранены позднее, либо сторона защиты, суд не обратили на них внимание;

- «антиобразиы» - специально подобранные авторами документы из практики, которые содержат существенные нарушения закона. Соответствуюшие дела завершались поражением стороны обвинения. Антиобразцы снабжены специальными заданиями с тем, чтобы научить, как не допускать такие нарушения или устранять их вредные последствия

Лишь один образец приведен в Приложение 2 (постановление о привлечении в качестве обвиняемого). Однако работники правоохранительных органов, общественные помощники, преподаватели и 
студенты вузов, кто пожелает использовать весь объем электронных приложений, могут обратиться на сайт labatr.bsu.ru, где есть ссылка «Электронные приложения к Руководству для следователя и его помощника, практиканта».

Скачав этот архив, пользователи увидят в нем следующие разделы:

1. «Приложения 1-16» - содержат электронные документы - peальные акты правоприменения, а иногда и задания к ним для глав пособия согласно их нумерации.

2. «Дела реальные» - содержат образцы и примеры, которые собраны в отдельные учебные уголовные дела. Они включают не все, но основные акты по исходному (реальному) делу, а потому отвечают требованиям наглядности и практичности этого специфического учебного материала.

3. «Методические материалы» - содержат различные документы по вопросам организации учебного процесса в юридических вузах и учреждениях повышения квалификации, вопросам прохождения практик и т.П.

4. «Публикации авторов» - содержат некоторые из авторских публикаций, которые авторы вправе распространять в электронном виде.

Работники правоохранительных органов, использующие данное «Руководство...» в работе, а также все желающие, прежде всего студенты, могут составлять свои проекты документов на компьютере, взяв за основу соответствующий электронный документ из электронных приложений.

Однако предупреждаем: подавляющая часть предложенных документов правоприменительной практики изложена в редакиии авторов - практических работников. Составители не гарантируют отсутствия в них ошибок и нарушений закона, а иногда и намеренно их оставляют. Таким образом, ошибка, скопированная из образцов, примеров и антиобразиов, ничем не лучше собственных и любых других. Каждому из пользователей по каждому реальному документу советуем дать оценку по наличию/отсутствию в нем нарушений закона или ошибок.

Авторский коллектив постарается регулярно обновлять все названные разделы электронных приложений, улучшать качество представленных документов. Все желающие могут направлять авторскому коллективу свои примеры и образцы электронных документов по адресу: garmaeff@yandex.ru.

Убедительно просим, чтобы эти документы соответствовали следующим требованиям:
- они должны быть получены законным путем, в необходимых случаях с согласия их составителей;

- их источником должны быть уголовные дела и материалы, по которым правовые решения вступили в законную силу;

- они не должны содержать сведения, составляющие государственную или иную охраняемую законом тайну, относиться к объектам авторского права;

- по возможности в них не должно быть ошибок и нарушений закона. Если таковые имеются, необходимо сопроводить текст соответствующими сносками или примечаниями о том, в чем заключается ошибка (нарушение закона), как ее следует исправить.

Искренне надеемся, что данное руководство и электронные приложения к нему принесут реальную пользу как практическим работникам, так и обучающимся. 
Глава 2

\section{КАК ПОМОЧЬ ПРАВИЛЬНО СИСТЕМАТИЗИРОВАТЬ И «ПОДШИТЬ» ДЕЛО}

\section{1. Систематизация несложного уголовного дела в отношении одного обвиняемого}

Насколько нам известно, практически ни в одном классическом юридическом вузе страны почему-то не учат тому, как «подшивать» дело, систематизировать его материалы. Иногда по своей инициативе, но помимо учебного плана, этим занимаются отдельные преподаватели - процессуалисты, криминалисты и другие - бывшие практические работники, каковых в вузах традиционно меньшинство ${ }^{7}$.

Между тем с этой непростой задачей каждый молодой специалист, прежде всего следователь, дознаватель, сталкивается буквально в первый же день своей работы. Причем в период расследования дела «подшивать» приходится два, три и более раза. Кроме того, умение следователя грамотно, аккуратно и даже красиво «подшить» дело считается несомненным атрибутом его профессионального мастерства. Научился «подшивать» грамотно - уже не новичок, причем алгоритм первой «подшивки» и, например, последней (по окончании расследования) существенно отличается. Мы рассмотрим алгоритм заключительной, на стадии предварительного расследования, систематизации ${ }^{8}$.

Следует руководствоваться общими принципами размещения материалов дела: хронологическая последовательность (от более поздних к менее поздним), логическая связанность; необходимость группировки документов по конкретному вопросу или лицу в одном месте, исключая нахождение аналогичных документов в разных местах. Однако эти принципы в конкретном приложении иногда противоречат друг другу. Посмотрим, как преодолеть эти противоречия.

${ }^{7}$ Примеры описей по уголовному делу, материалу размешены на сайте labatr.bsu.ru, ссылка на данное руководство, электронное приложение № 2.

${ }_{8}^{8}$ Необходимо отметить, что в некоторых прокуратурах и следственных управлениях Следственного комитета при прокуратуре РФ по субъектам РФ, например, по Свердловской области, действуют приказы о правилах систематизации материалов дел. Изложенные в них рекомендации могут отличаться от приведенных в настоящем пособии.
В следственных подразделениях России сложился следующий примерный алгоритм систематизации материалов несложного уголовного дела, когда речь идет об одном обвиняемом при небольшом количестве эпизодов/составов преступлений 9

1. Все документы уголовного дела должны быть пронумерованы, аккуратно подшиты, по возможности в твердых обложках; желательный объем 1-го тома примерно 250 листов. При необходимости можно и больше, но не желательно.

2. Указания руководителя следственного органа о направлении расследования, производстве отдельных следственных действий, планы расследования по делу подшиваются перед постановлением о возбуждении уголовного дела (черновые подшивки). При подготовке уголовного дела для передачи обвиняемому и его защитнику в порядке ст. 217 УПК РФ (для ознакомления) упомянутые указания оставляются в материалах, в случае, если они носят процессуальный характер, например, обязывают следователя провести следственные действия. Если же указания касаются непроцессуальных вопросов: тактики расследования, необходимости устранения допущенных ошибок и т.п., то они изымаются из дела и приобщаются к надзорному производству (НП). Это касается и планов расследования. Это также непроцессуальные документы.

3. При направлении уголовного дела в суд сразу после передней обложки подшивается бланк справки о результатах судебного рассмотрения, а также опись.

4. Далее за описью в начале дела располагаются: постановление о возбуждении уголовного дела (постановление о принятии дела к производству), рапорты (заявления) и материал проверки (объяснения, справки), послужившие основанием для возбуждения уголовного дела. Чаще всего именно здесь размещается блок материалов доследственной проверки или результатов оперативно-розыской деятельности.

5. Постановления об изъятии и передаче уголовного дела, постановления о принятии дела к производству, постановления о продлении сроков следствия и содержания под стражей (с постановлением о возбуждении ходатайств перед судом о продлении стражи $\left.{ }^{10}\right)$, постановле-

${ }_{9}^{9}$ В различных ведомствах, на различных территориях, у отдельных следователей наблюдаются разные подходы к «подшивке» дела. Предлагаемый порядок есть некоторое усредненное представление о систематизации материалов, которая, как известно, на нормативном уровне нигде не закреплена.

${ }^{10}$ В ряде регионов неписанные правила систематизации в этой части существенно отличаются. Так, в Республике Бурятия постановления об избрании мер пресечения, ходатайства об их избрании, ходатайства и решения «о продлении...», изменении мер пресечения под- 
ния о приостановлении и возобновлении предварительного расследования, уведомления об этом соответствующих участников процесса.

6. Протоколы осмотра места происшествия, осмотра трупа, постановления о назначении судебных экспертиз, протоколы ознакомления обвиняемых и потерпевших с постановлениями о назначении экспертиз, заключения экспертов, протоколы ознакомления с заключениями экспертов, протоколы допросов экспертов

7. Постановления и протоколы о производстве выемок, обысков, осмотров вещественных доказательств, постановления о признании и приобщении вещественных доказательств, расписки о возврате, расписки о передаче на ответственное хранение.

8. Постановления о признании потерпевщим, протоколы допросов потерпевшего, постановления о признании представителем или законным представителем. За протоколами допроса потерпевшего идет весь характеризующий его материал, в том числе документы, удостоверяющие его личность.

9. Протоколы допросов свидетелей. При допросе одного и того же лица несколько раз протоколы подшиваются вместе, по хронологии (по датам).

10. Материалы, собранные в связи с привлечением лица в качестве обвиняемого: протоколы задержания в порядке ст.ст. 91-92 УПК РФ постановления о применении и изменении меры пресечения; ордер адвоката-защитника, показания, данные им в качестве свидетеля, подозреваемого, постановление о привлечении в качестве обвиняемого, протокол допроса обвиняемого, протоколы последующих следственных действий (допросы, очные ставки, следственные эксперименты, проверки показаний на месте) с его участием (подшивать по хронологии). После протоколов следственных действий по каждому обвиняемому сразу следует подшивать характеризующий его материал.

11. Иногда далее подшивают блок документов - результатов оперативно-розыской деятельности: отдельные поручения следователя в порядке ст. 38 УПК РФ, справки оперативников о проделанной работе, протоколы, акты применения служебно-розыскной собаки, постановления о рассекречивании сведений и др.

12. Материалы, устанавливающие и характеризующие личность обвиняемого: копия паспорта (свидетельство о рождении, карточка формы № 1), справки о судимостях, состоянии здоровья, составе семьи, награ-

шиваются в «блок обвиняемых», после протокола задержания в порядке ст. 91 УПК РФ, перед протоколами допросов подозреваемого, обвинением, допросом обвиняемого. дах, характеристики, требование о судимостях, копии приговоров. При этом ответ на запрос следует подшивать сразу после соответствующего запроса. После каждого запроса должен быть ответ. Кроме того, следует подшить все ответы по судимостям за требованием о судимостях. При этом запросы с приговорами нужно расположить по хронологии (от более ранних к более поздним). Запросы и характеристики также следует подшивать не в разброс, а «блоком». Если направляются напоминания, подшивать за запросом, по которому направлено напоминание.

13. Иное: исковые заявления, постановления о наложении ареста на имущество, вклады, протоколы наложения ареста; постановления о передаче ценностей на хранение.

14. Постановления о прекращении уголовного дела (уголовного преследования), о выделении материалов.

14. Представления в порядке ч. 2 ст. 158 УПК РФ.

15. Протокол об объявлении обвиняемому и его защитнику об окончании следствия.

16. Протокол ознакомления потерпевшего с материалами дела (уведомления).

17. Протокол ознакомления обвиняемого с материалами дела, графики ознакомления, ходатайства и постановления о разрешении ходатайств. По некоторым уголовным делам, например, по обвинению в совершении преступления, предусмотренного соответствующим пунктом ч. 2 ст. 105 УК РФ, здесь же подшиваются отдельные протоколы ознакомления обвиняемых с их правами по ч. 5 ст. 217 УПК РФ (вопросы суда присяжных и прочее).

18. Обвинительное заключение со списком лиц и справкой (ст. 220 УПК РФ)

19. Уведомление потерпевшему, а также обвиняемому и его защитникам о направлении дела в суд.

20. Расписка в получении обвинительного заключения.

Если материалов больше, чем 1 том, целесообразно разделять документы не произвольно, а так: во 2-й (отдельный) том выделить только «блок» (следственные действия и за ними характеризующий материал) потерпевшего и «блоки» (следственные действия и за ними характеризующий материал) на обвиняемого.

При составлении документов следует обязательно оставлять поля для подшивки. Как подшить протокол следственного действия, если там не соблюдены поля? Надо вырезать полосу белой бумаги шириной 2,5 см по высоте протокола. Приложить этот вырезанный листок вплотную к левому краю протокола и склеить скотчем (вертикально од- 
ной полосой) с обеих сторон. Скотч ровнее ложится, если его держать за оба конца над местом склеивания и начинать опускать на листки с центральной части скотча. Затем на ту же ширину $(2,5$ см) загнуть по вертикали правую часть протокола и оставить в таком положении. Теперь можно подшивать. И текст в протоколе будет читаться, и протокол не будет торчать из дела.

\section{2. Систематизация многотомных и многоэпизодных групповых дел}

Для таких дел наиболее приемлемо размешение материалов по эпизодам и лицам, участвовавшим в преступной деятельности, а именно:

1. Первый том (группа томов):

1.1. Постановление о возбуждении уголовного дела (дел), о принятии его к производству, о создании следственной группы, об изменении в ее составе.

1.2. Протоколы ознакомления обвиняемых с составом следственной группы ${ }^{11}$.

1.3. Постановления о продлении сроков следствия и содержания обвиняемых под стражей

1.4. Постановления о соединении, выделении дел, указания о проведении дополнительного расследования.

1.5. Материалы, полученные следователями до возбуждения дела (результаты проверочных, оперативно-розыскных мероприятий). Чаше всего подшивается в начало материалов по каждому из эпизодов преступлений.

2. Второй том (группа томов) - материалы, касающиеся отдельных эпизодов и причастных к ним лиц:

2.1. Постановления о назначении экспертиз и ревизий; заключения и акты; протоколы ознакомления с последними.

2.2. Постановления и протоколы производства выемки документов, а также различные материалы, полученные из учреждений, организаций и предприятий (с запросами о них).

2.3. Представления в порядке ч. 2 ст. 158 УПК РФ

3. Третий том (группа томов):

3.1. Материалы по конкретным эпизодам преступной деятельности в хронологическом порядке. По каждому эпизоду - показания

${ }^{11}$ Бланка такого протокола нет, и не было в ст. 476 УПК РФ (в редакции до 11.08.2007). Во многих регионах обвиняемые расписываются об ознакомлении прямо в постановлении о создании следственной группы. свидетелей и потерпевших, бухгалтерские и прочие документы. Здесь же материалы, касающиеся всех или нескольких эпизодов и лиц. Размещение документов о мероприятиях, относящихся к нескольким обвинениям, следует описывать в справочном листке к этому тому, группе томов (неофициальный документ).

3.2. Здесь же могут быть размешены данные, характеризующие потерпевших.

4. Четвертый том (группа томов): материалы по поводу привлечения в качестве обвиняемых. По каждому обвиняемому группируются в определенной последовательности:

4.1. Его показания, будучи свидетелем, подозреваемым;

4.2. Само обвинение и показания по предъявленному обвинению.

4.3. Постановления о применении или изменении мер пресечения.

4.4. Протоколы последующих допросов обвиняемого. Собственноручные заявления, ходатайства.

4.5. Документы, характеризующие личность: справки о судимости, состоянии здоровья, составе семьи, наградах, характеристики (работа, место жительства и др.), копии приговоров по предыдущим судимостям и т. Д.

4.6. Постановления и протоколы производства выемок и обысков.

4.7. Постановления и иные документы по поводу ареста на имушество.

5. Пятый том (группа томов):

5.1. Постановления о прекращении дела в отношении отдельных лиц, в части отдельных эпизодов и др.

5.2. Постановления о выделении материалов (дел) в отдельные производства и описи этих материалов.

5.3. Документы по поводу окончания следствия и ознакомления обвиняемых и их защитников с материалами дела.

5.4. Ходатайства стороны защиты и решения следователя по ним, включая материалы проведения дополнительных следственных действий.

5.5. Обвинительное заключение со всеми приложениями. Документы о направлении дела в суд.

\section{3. Дополнительные рекомендации по систематизации и подшивке материалов уголовных дел}

Все документы уголовных дел должны быть надежно и аккуратно подшиты в тома, в обложки, установленной формы. Желательный объем 
одного тома - примерно 250 листов. Для того чтобы правильно организовать ознакомление с делом, тома должны быть небольшими по объему, что позволит читать их нескольким обвиняемым и их защитникам.

К обвинительному заключению по делу, состоящему из нескольких томов, прилагается справка с указанием порядка расположения основных материалов дела.

Логически связанные между собой документы должны располагаться рядом. Например, постановление о назначении экспертизы и заключение экспертизы, постановление о производстве обыска и протокол обыска.

Приложения к протоколу в виде схем, таблиц, рисунков должны приобщаться вслед за соответствующим протоколом и иметь необходимые пояснения о том, кем, когда и по поводу чего составлено то или иное приложение, дату и наименование протокола. На приложениях должна иметься подпись следователя.

В описи следует указывать не просто название документа, но и конкретные сведения о нем, то есть фамилию свидетеля, наименование и дату судебной экспертизы. Для аккуратной и быстрой подшивки томов дела рекомендуется пользоваться специальными станками различной конструкции, укладывая листы дела лицевой стороной вниз, ровняя их по краям и равномерно укладывая листы дела, чтобы толщина тома была одинаковой. После зажима корешков тома планкой необходимо просверлить не менее пяти отверстий при помощи дрели или шила. Отверстия прошиваются суровой ниткой, после чего том извлекается из станка и к нему пришивается обложка. Существуют конструкции станков, в которых возможно пришить обложку сразу (рис. 1, 2)

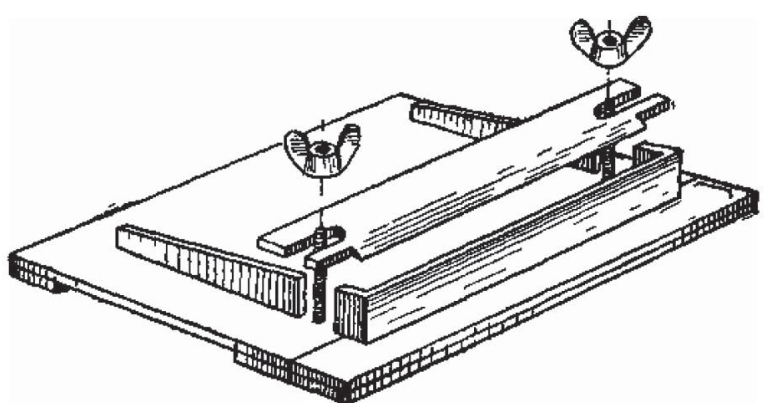

Рис. 1. Общий вид одного из типовых станков для подшивки
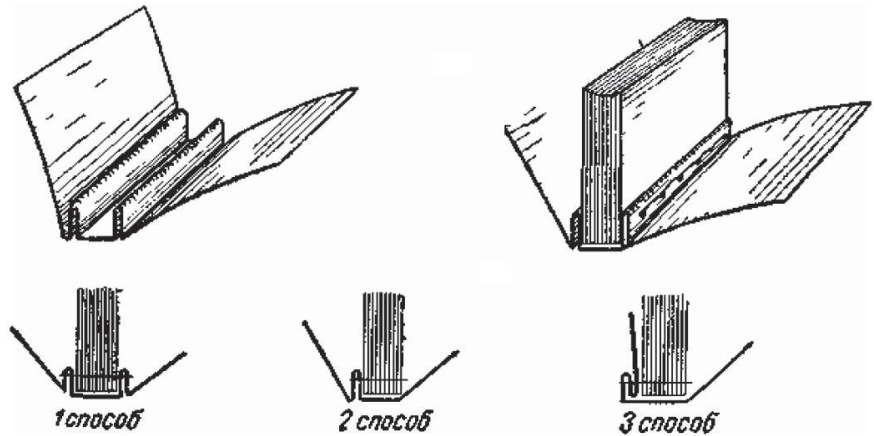

Рис. 2. Способы подшивки обложки к тому 


\section{Глава 3}

\section{ПАПКА ДЛЯ БУМАГ «ВЫЕЗДНАЯ» И ПРОЧИЕ ДЕТАЛИ}

Необходимо исходить из того, что большинство следователей и дознавателей в нашей стране - это настоящие профессионалы своего дела или подающие такие надежды. Но все же очень уж большой процент среди них - молодые специалисты. Да и всем нам, как и каждому человеку вообще, свойственны порой забывчивость, рассеянность. Особенно когда в производстве следователя совершенно невообразимое количество уголовных дел, материалов и т.п.

Уважаемые коллеги - начинающие следователи! Если порой некоторая рассеянность присуща и вам, а дел в производстве действительно много - эти рекомендации для вас.

Уважаемые общественные помощники, практиканты! Давайте поможем курирующему следователю, дознавателю в том, что должно быть у него под рукой всегда, в чем он нуждается чаще всего и больше всего - в бланках процессуальных документов.

На самом деле следственные чемоданчики, поступающие в следственные подразделения, нуждаются в существенном пополнении. Кроме прочих недоработок, следует констатировать отсутствие приспособлений для хранения следственных документов. А может оно и не нужно? Может каждый следователь должен сделать это приспособление себе сам? Может быть, но делает это, к сожалению, не каждый.

Уважаемый помощник, практикант! Сходите в магазин канцтоваров и купите 44 пластиковых файла. Далее нужно сделать следующее:

- по углам файлов в местах крепления прозрачным скотчем приклеить номера;

- согласно прилагаемой описи документов распределить бланки по файлам;

- саму опись поместить в файл без номера и положить в дипломат перед файлом № 1;

- при выезде на место происшествия первоначально необходимо извлечь файл с описью документов;

- найдя в описи нужные бланки, достаем из дипломата по номеру нужные файлы (документы). Если бланки в файлах закончились, пустой файл обратно класть не следует, иначе можно забыть пополнить дипломат нужными документами;
- пустой файл желательно положить отдельно, где копятся материалы проверки или уголовного дела по дежурным суткам. При возвращении в прокуратуру сразу будет заметен пустой файл;

- после распечатки нужного количества бланков, файл, согласно его нумерации, возвращается в следственную папку.

Нецелесообразно применять различные подшивки файлов. Это, во-первых, неудобно. При необходимости применить один бланк (под одним номером) придется из следственной папки извлекать всю объемную подшивку. Во-вторых, пластиковые подшивки файлов быстро приходят в негодность, особенно на морозе.

\section{ОбраЗец ОПИСИ ПАПКИ ДЛЯ БУМАГ СЛЕДОВАТЕЛЯ:}

1. Рапорт об обнаружении признаков преступления; протокол принятия устного заявления о преступлении.

2. Протокол явки с повинной.

3. Повестки; бланки с угловым штампом.

4. Протокол осмотра места происшествия.

5. Протокол осмотра трупа.

6. Обязательные вопросы различных экспертиз.

7. СМЭ - труп.

8. СМЭ - телесные повреждения.

9. СМЭ - изнасилование.

10. Постановление о возбуждении уголовного дела и принятии к производству.

11. Протокол задержания подозреваемого.

Сообщение о задержании подозреваем_ 12.

Уведомление адвокату.

12. Постановление о производстве освидетельствования; протокол освидетельствования.

13. Поручение о производстве отдельных следственных действий (оперативно-розыскных, розыскных мероприятий).

14. Объяснение.

15. Протокол допроса подозреваем _ ; у уведомление для адвоката о явке в суд для избрания меры пресечения.

16. Протокол допроса несовершеннолетнего подозреваем

17. Протокол допроса обвиняем

${ }^{12}$ Обычно на место происшествия этот бланк не берется, поскольку, чаше всего, составляется позже в кабинете и вместе с постановлением о возбуждении уголовного дела передается прокурору. При этом решение о задержании подозреваемого, как правило, согласовывается с прокурором либо с его заместителем. 
18. Протокол дополнительного допроса обвиняем

19. Протокол допроса несовершеннолетнего обвиняем

20. Постановление о допуске заключенного ПРЕДСТ. Несовершеннолетнего обвиняемого (подозреваем_).

21. Протокол проверки показаний на месте (для подсудимого и обвиняемого).

22. Постановление о признании потерпевш_.

23. Протокол допроса потерпевш_.

24. Протокол допроса несовершеннолетн__ потерпевш_(свидетеля).

25. Протокол допроса свидетеля (потерпевш_) с участием переводчика.

26. Протокол допроса свидетеля.

27. Протокол проверки показаний на месте (для свидетеля и потерпевшего, подозреваемого (обвиняемого).

28. Протокол очной ставки.

29. Постановление о назначении переводчика.

Подписка о предупреждении переводчика об уголовной ответствен-

ности за заведомо неправильный перевод.

30. Протокол Пред. лица для опознания

31. Протокол Пред. лица для опознания в условиях, исключающих визуальное наблюдение им опознающего.

32. Протокол предъявления предмета для опознания.

33. Протокол опознания трупа.

34. Постановление о возбуждении перед судом ходатайства о производстве обыска (выемки) в жилище.

35. Постановление о производстве обыска (выемки) в случаях, не терпящих отлагательств.

36. Уведомление о производстве осмотра жилища, обыска (выемки) в жилище.

37. Постановление о производстве обыска (выемки)

38. Протокол обыска (выемки).

39. Протокол следственного эксперимента.

40. Постановление о получении образцов для сравнительного исследования.

41. Протокол получения образцов для сравнительного исследования.

42. Постановление о производстве осмотра жилища в случаях, не терпящих отлагательств.

Протокол осмотра жилища (помещения)

43. Бланки бытовых характеристик ${ }^{13}$.

3 Электронная папка с подборкой указанных ниже бланков размещена на сайте labatr.bsu. $\mathrm{ru}$, ссылка на данное руководство, электронное приложение № 3. Подробнее см. 1.4. Будь-
Преимущества такого формирования папки для бумаг очевидны. Это, прежде всего, оперативность работы с документами. Приведем пример по конкретному делу. Выехав на убийство, где подозреваемый (или потерпевший) является несовершеннолетним, при наличии соответствующих бланков сразу на месте происшествия можно объявить постановление о признании законным представителем несовершеннолетнего, дать заранее подготовленные (бланки) уведомления о приглашении на допрос в качестве подозреваемого, предъявления обвинения и избрания меры пресечения. При отсутствии указанных документов в большинстве случаев возникают существенные проблемы при выполнении следственных действий в последующем. Так, вернувшись в прокуратуру, следователь пытается допросить задержанного, а законные представители подозреваемого своего обещания прибыть в прокуратуру не выполнили. Если постановление о признании законным представителем подозреваемого или близкими родственниками подписано на месте и они получили уведомления о дате выполнения следственного действия, следователь спокойно может провести необходимые мероприятия с несовершеннолетним подозреваемым (обвиняемым) и без участия законного представителя. Но если упомянутые документы своевременно составлены не были? Тогда начинается «беготня» за родственниками задержанного. Подобных примеров можно привести множество.

Не менее важное значение имеют различные мелочи в следственном дипломате. Будьте уверены, почти каждый следователь, как бы он ни был организован, нет-нет да что-нибудь забудет. А тут вы, уважаемый общественный помощник (практикант), со всем необходимым! Как приятно будет старшему товарищу! Итак:

- многие следователи держат в своем чемоданчике твердый планшет с зажимом - креплением сверху для листа формата А 4. Такой продается в любом магазине канцтоваров. На нем в полевых условиях удобно разместить документ и писать в отсутствие иной твердой поверхности, на нем же можно перекусить в походных условиях и т.п. ${ }^{14}$;

- зимой на выезде нужно иметь незамерзающую ручку. В настоящее время их множество (капиллярные, гелевые, в виде тонких фломастеров и т. д.). Без такой детали невозможно будет вести записи на месте происшествия при минусовой температуре. Правда, в сильные моро-

те внимательны, проверяйте бланки! В связи с изменениями уголовно-процессуального законодательства их содержание может устареть.

14 В те годы, когда магазины канцтоваров не были так богаты, как сейчас, автор этих рекомендаций держал в чемоданчике алюминиевый лист формата А 4 и толщиной 1,5 мм. Удобно и очень долговечно. 
зы замерзают практически любые ручки (да и руки), поэтому лучше делать заметки обычным мягким карандашом, а потом в машине (в теплом помещении) по своим заметкам составить протокол;

- кстати, не забудьте тепло одеться и обуться на выезде зимой. Сколько нашего народа слегло с болезнями из-за неподходящей одежды осенью и зимой на выезде;

- летом в Сибири не обойтись без противокомариных средств. Недорогое и вполне сносное - «Комарекс». Но есть более современные и эффективные;

- ночью выручит небольшой аккумуляторный фонарь. Стоит он недорого. В эксплуатации никаких дополнительных затрат не требует. Фонарь с батарейками дорог в эксплуатации. После каждого выезда на место происшествия приходится закупать батарейки. Аккумуляторные фонари при необходимости заряжаются через электрические розетки. Еще более эффективным может стать мобильный телефон с функцией фонарика. Его же можно использовать для фотоснимков, но все же настоящий фотоаппарат, как правило, лучше;

- в настоящее время в магазинах продаются фонари со встроенным ультрафиолетовым светом. Они также могут очень пригодиться следователю по делам о взяточничестве, изнасиловании и др. Так, по делам о преступлениях, предусмотренных ст. 131 УК РФ, свет такой лампы поможет определить, какую именно одежду потерпевшей либо подозреваемого нужно изъять для проведения биологической экспертизы;

- следует иметь с собой копировальную бумагу, рулетку, скальпель, пинцет, компас, упаковочный материал (пакеты, скотч, клей и т.п.) бирки с печатями для опечатывания вешественных доказательств, помещений, ножницы и пр. При этом канцелярские ножницы не подходят. Кроме бумаги, они ничего не режут. Необходимо приобрести специальные металлические ножницы. Они позволят без особого труда разрезать материю, веревки и т. д.;

- рекомендуется иметь выдвижной канцелярский нож с широким лезвием. Кроме того, в следственных чемоданчиках иногда есть перочинный нож (необходимо для срезывания фрагментов обоев, соскобов краски, въевшейся в пол крови и т. д.), прочная тонкая веревка - трос (например, для извлечения трупа из колодца), линейка и обязательно марля (для изъятия смывов и соскобов ${ }^{15}$

\footnotetext{
$\overline{15}$ Подробнее о предметах, необходимых для осмотра места происшествия, см. гл. 3; 7.1.
}

Глава 4

\section{ПРОВЕДЕНИЕ ДОСЛЕДСТВЕННОЙ ПРОВЕРКИ, СИСТЕМАТИЗАЦИЯ МАТЕРИАЛОВ}

Всем, кому адресована эта книга, хорошо известно, что в соответствии со ст.ст. 144, 145 УПК РФ следователь после принятия сообщения о преступлении проверяет его и в пределах своей компетенции принимает по нему в установленный законом срок одно из следующих решений:

- о возбуждении уголовного дела;

- об отказе в возбуждении уголовного дела;

- о передаче сообщения по подследственности

Проверка сообщений существенно ограничена по срокам, а реализовать необходимо довольно большой объем работы: отобрание многочисленных объяснений, получение заявлений, документов и их копий, проведение проверок, ревизий и др. Только по результатам полной и всесторонней проверки следователь вправе принять правовое решение в порядке ст. 145 УПК РФ

Здесь помощь общественного помощника (практиканта) может оказаться незаменимой. Ему может быть поручено составление проектов запросов об истребовании документов и даже проект процессуального решения по результатам проверки ${ }^{16}$. Не исключено, что следователь может поручить общественному помощнику даже отобрание некоторых объяснений. При этом он может либо предложить опрашиваемому лищу написать их собственноручно, либо сам составить текст ${ }^{17}$.

Уважаемый общественный помощник, практикант! Прежде всего попросите курирующего следователя показать вам составленный им самим аналогичный документ. Именно он будет основным шаблоном. Кроме того, не стоит забывать, что в объяснении должно быть указано следующее:

${ }^{16}$ Так, обязанность готовить в соответствии с поручением следователя проекты документов прямо предусмотрена п. 18 Положения, утвержденного Приказом председателя СК при прокуратуре РФ № 50 от 15.05.2008 (см. Приложение 1).

${ }_{17}^{17}$ Однако есть мнение, что практиканту вообще нельзя доверять отобрание объяснений. По мнению многих практических работников, это должен делать только следователь, поскольку такой подход больше соответствует духу закона. Другой вариант: участие в (см. 6.6). В любом случае, по этому принципиально важному вопросу следует выяснить мнение руководства следственного органа. 
- ФИО лица, дающего объяснение;

- место жительства и регистрации;

- место работы;

- контактный телефон;

- сведения о судимости;

- пояснения лица об обстоятельствах, указанных в сообщении о преступлении;

- д дополнения лица (если имеются);

- запись: «Написано мною собственноручно» либо «Мною прочитано, с моих слов записано верно»;

- дата составления объяснения;

- подпись лица с ее расшифровкой ${ }^{18}$.

Кроме того, необходимо, чтобы в тексте объяснения опрашиваемому были письменно разъяснены положения ст. 51 Конституции РФ, так как указанный документ в отдельных случаях может рассматриваться в дальнейшем в качестве доказательства по уголовному делу ${ }^{19}$

На практике бывают случаи, когда опрашиваемое лицо желает самостоятельно подать заявление либо по поводу рассматриваемого сообщения, либо по другому преступлению. Общественный помощник (практикант) здесь может помочь в составлении заявления, в котором должно быть указано следующее:

• лицо или орган, в который направляется заявление;

- ФИО лица, подающего заявление;

- место жительства и регистрации;

- место работы;

- контактный телефон;

- обстоятельства, по поводу которых подается заявление;

- что именно просит заявитель;

- дата составления заявления;

- подпись лица с расшифровкой.

В случае, если в заявление имеется указание на совершение кемлибо преступления, в документе должно быть отмечено, что заявителю разъяснены положения ст. 306 УК РФ об уголовной ответственности за заведомо ложный донос.

${ }^{18}$ Примеры этих и других процессуальных документов размещены на сайте labatr.bsu.ru, ссылка на данное руководство, электронное приложение № 4. Подробнее см. 1.4.

${ }_{19}$ Многие судьи, следователи, ученые-процессуалисты возражают против признания письменных объяснений доказательствами по делу. Но практика большинства регионов часто идет по этому пути, а вопросы допустимости доказательств не входят в предмет данного пособия
После получения заявления о совершении другого преступления, не имеющего отношения к рассматриваемому сообщению, общественный помощник (практикант) должен передать его следователю для регистрации и принятия правового решения в установленном законом порядке.

При истребовании документов в государственных, муниципальных учреждениях, коммерческих организациях и у предпринимателей общественному помощнику (практиканту) необходимо оформить проект запроса, передать следователю на проверку и затем получить его подпись. Вновь попросите куратора показать вам составленный им самим аналогичный документ. В запросе обычно указывается следующее:

- организацию или лицо, в адрес которого направляется запрос;

- кратко суть поступившего сообщения о преступлении ${ }^{20}$;

- перечень запрашиваемых документов и сведений;

- указание на правомочия следователя (ст. 38 УПК РФ, ст. 22 ФЗ «О прокуратуре РФ» и др.);

- указание на срок, в течение которого запрос должен быть исполнен;

- указание на процедуру направления ответа следователю (нарочным, почтой, факсимильной связью и т.д.);

- контактный телефон следователя, адрес доставки ${ }^{21}$.

Запрос должен быть составлен на бланке следственного органа. Необходимо зарегистрировать исходящий документ в канцелярии в установленном порядке с указанием номера, даты и т.п. При этом запрос составляется в двух, иногда в трех экземплярах, один из которых приобщается к материалам проверки.

Добросовестный общественный помощник и практикант помнит о том, что срок проверки сообщения о преступлении ограничен тремя сутками. В случае, если закончить проверку в указанный срок не представляется возможным, руководитель следственного органа может продлить этот срок до 10 суток, а в случае необходимости проведения документальных проверок или ревизий - до 30 суток. Продление осуществляется путем вынесения постановления о возбуждении ходатайства о продлении срока проверки и утверждения его руководителем следственного органа, органа дознания или прокурора (ч. 3 ст. 144 УПК РФ). Составление проекта этого документа иногда можно поручить об-

${ }^{20}$ Посоветуйтесь со следователем, насколько подробно нужно изложить фабулу. Иногда, в интересах обеспечения тайны предварительного расследования, следователь разрешит указать только номер уголовного дела.

${ }^{21}$ Если он отличается от юридического адреса следственного органа. Юридический адрес обычно указывается на бланке. 
щественному помощнику (практиканту). Только вновь попросите у следователя составленный им аналогичный документ.

После отобрания объяснений, заявлений, получения копий документов следователь принимает решение по результатам проверки сообщения о преступлении. Общественный помощник может помочь следователю собрать, проанализировать, подшить материалы, а квалифицированный и опытный помощник - составить проект одного из постановлений: о возбуждении уголовного дела; об отказе в возбуждении уголовного дела; о передаче сообщения по подследственности.

Постановление о возбуждении уголовного дела составляется в соответствии с ч. 2 ст. 146 УПК РФ. При этом общественному помощнику, кроме прочего, необходимо проверить, соблюдены ли требования ст. 147 УПК РФ при возбуждении дела частно-публичного обвинения об обязательном наличии заявления потерпевшего.

Постановление об отказе в возбуждении уголовного дела составляется в соответствии со ст. 148 УПК РФ. При этом в тексте постановления необходимо указать следующее:

- место, дату и время вынесения постановления;

- когда было получено сообщение о преступлении, его краткое содержание;

- результаты проверки по нему (объяснения опрошенных лиц, результаты исследования документов и др.);

- принятое по результатам проверки правовое решение;

- разъяснение заинтересованным лицам процедуры обжалования принятого решения;

- указание на направление копии решения надзирающему органу.

Теперь рассмотрим порядок систематизации, подшивки материалов проверки в порядке ст. 144, 145 УПК РФ, поскольку очевидно, что эта работа может и должна быть делегирована общественным помощникам. А по уровню необходимой квалификации с ней может справиться и добросовестный практикант.

Далее речь пойдет о двух основных видах систематизации:

1. Если по материалам проверки возбуждено уголовное дело и они стали его частью (см. П. 1 ч. 1 ст. 145 УПК РФ);

2. Если по материалам проверки принято решение об отказе в возбуждении уголовного дела, то документы собираются, подшиваются в отдельный том (см. п. 2 ч. 1 ст. 145 УПК РФ);

По первому виду систематизации на практике, в свою очередь, получило распространение два основных метода:
1.1. группировка всех материалов единым блоком, после постановления о возбуждении уголовного дела и непосредственно перед документами собственно предварительного следствия;

1.2. распределение данных материалов по уголовному делу раздельными блоками - в зависимости от их содержания, например, по лицам: объяснения опрошенных лиц и другие материалы в отношении этого лица - перед протоколами их последующих допросов и т.д.

Метод 1.2 по, видимому, исходит из задачи наглядно показать суду позицию опрошенного и в последуюшем допрошенного лица в хронологической последовательности - от предварительной проверки до окончания предварительного расследования. Вряд ли такой метод оптимален. По смыслу ст.ст. 6, 7, 240, 252, 297 УПК РФ суд должен дать оценку, в том числе законности возбуждения уголовного дела. В случае, если материалы проверки распределены разрозненными блоками по всему тому (томам), судье, другим участникам процесса намного труднее дать оценку законности принятия этого важного правового решения. Поэтому более правильным представляется использование первого метода систематизации (1.1).

Теперь кратко о «внутренней» последовательности подшивки документов доследственной проверки в общем томе (томах) уголовного дела. Оптимальным считается систематизация этих материалов по тому же алгоритму, что используется в отношении материалов всего уголовного дела:

1. Сразу после постановления о возбуждении уголовного дела подшиваются документы, которые указывают на поводы и основание его возбуждения:

а) заявление о преступлении в порядке ст. 141 УПК РФ²2, в котором в обязательном порядке должна быть отметка о предупреждении заявителя об уголовной ответственности по ст. 306 УК РФ. В случае, если заявление было сделано по телефону или в устном виде, вместо него подшивается протокол, составляемый в порядке ч. 3 ст. 141 УПК РФ;

б) явка с повинной или протокол, составляемый в порядке ст. 142 УПК РФ;

в) рапорт об обнаружении признаков преступления в порядке ст. 143 УПК РФ ${ }^{23}$

22 Здесь и далее, разумеется, при наличии таких документов. Если названных и далее перечисляемых документов нет, переходим к следующему пункту перечня.

${ }^{23}$ На документах, указанных в п. а, б, в должен быть штамп с датой и номером регистрации сообщения о преступлении в «Книге учета сообщений о преступлениях» Органа внутренних дел или иного органа, осуществляющего предварительное следствие или дознание. 
2. Материалы производства по делуоб административном правонарушении Далеко не по всем уголовным делам, например, по фактам хулиганства, незаконного оборота наркотиков, нарушений различных правил безопасности и др., в практике распространено возбуждение уголовного дела по материалам дела об административном правонарушении (ст.ст. 6.8, 20.21, гл. 12 КоАП РФ и др.). В случае, если имеются основания для возбуждения уголовного дела, выносится постановление о прекращении производства по делу об административном правонарушении в порядке предусмотренном п. 7 ч. 1 ст. 24.5 КоАП РФ. Материалы подшиваются после указанных в П. 1 документов. Рассмотрим пример распространенной на практике систематизации материалов административного производства по факту изъятия у лица наркотического средства:

- сопроводительное письмо о направлении материалов производства по делу об административном правонарушении руководителю следственного органа, либо начальнику органа дознания, либо прокурору для передачи по подследственности;

- постановление о прекращении производства по делу об административном правонарушении в порядке п. 7 ч. 1 ст. 24.5 КоАП РФ;

- протокол о применении мер обеспечения производства по делу об административном правонарушении, предусмотренных ст. 27.1 КоАП РФ. В большинстве случаев это протокол доставления или задержания лица (ст.ст. 27.2, 27.3 КоАП РФ), или протокол личного досмотра физического лица (ст. 27.7 КоАП РФ);

- протокол об административном правонарушении, предусмотренном ст. 6.8 КоАП РФ, составленный в порядке ст. 28.2 КоАП РФ;

- материалы производства по делу об административном правонарушении, собранные в порядке, предусмотренном гл. 26 КоАП РФ. Подшиваются блоками в хронологическом порядке. Здесь последовательно систематизируются:

а) протоколы изъятия образцов, к примеру, смывов с рук или элементов одежды задержанного лица;

б) постановления о назначении экспертиз (в нашем примере - химических экспертиз изъятого вещества и смывов с рук или элементов одежды) и заключения экспертиз;

в) объяснения опрошенных лиц;

г) документы, предусмотренные ст. 26.7 КоАП РФ (подшиваются также в хронологическом порядке).

С указанной в штампе даты отсчитываются сроки для принятия правового решения, предусмотренные ч. 1 и 3 ст. 144 УПК РФ.
3. Протокол осмотра места происшествия, постановления о назначении судебных экспертиз с сопроводительными письмами о направлении таких постановлений в экспертные учреждения, протокол или акт освидетельствования лица ${ }^{24}$

4. Иные материалы, к числу которых можно отнести:

- справки (заключения) о проведенных в рамках доследственной проверки исследованиях (химические исследования по наркотическим веществам и т.п.);

- заключения документальных проверок и ревизий, проведенных до возбуждения уголовного дела;

- объяснения;

- акты ревизий, бухгалтерские и иные документы о хозяйственной деятельности;

- другие документы.

Как известно, в соответствии с ч. 3 ст. 144 УПК РФ руководитель следственного органа, начальник органа дознания вправе по ходатайству соответственно следователя, дознавателя продлить до 10 суток срок, установленный частью первой настоящей статьи. А при необходимости проведения документальных проверок или ревизий руководитель следственного органа по ходатайству следователя, а прокурор по ходатайству дознавателя вправе продлить этот срок до 30 суток. Ходатайства следователя (дознавателя) в порядке ч. 3 ст. 144 УПК РФ могут быть подшиты как после постановления о возбуждении уголовного дела, так и в порядке хронологии сбора документов.

Далее уже идут документы о следственных и иных процессуальных действиях, проводимых в рамках возбужденного уголовного дела (см. гл. 2).

Применительно к многоэпизодным уголовным делам следует использовать этот же способ систематизации. При этом материалы доследственных проверок по каждому эпизоду подшиваются непосредственного перед материалами предварительного расследования по соответствующему эпизоду.

${ }^{24}$ Напомним, что сама экспертиза должна быть проведена уже в рамках возбужденного уголовного дела. Нарушение данного правила может повлечь принятие решения о незаконности возбужденного уголовного дела и признание соответствующих доказательств недопустимыми. См., например: Надзорное определение Верховного суда РФ от 27 сентября 2006 г по делу № 32-Д06-39. Приговор по делу об умынленном причинении тяжкого вреда с экспертиза, на которую суд сослался как на доказательство вины осужденного, проводилась до возбуждения уголовного дела // СПС «Консультант Плюс: судебная практика 
Следует напомнить, что некоторые правила производства следственных действий должны применяться и при проведении проверочных мероприятий. В частности, опрос граждан в ночное время, за исключением случаев, не терпящих отлагательства, не допускается; опрашиваемым лицам следует разъяснять право, предусмотренное ст. 51 Конституции РФ. Следует соблюдать и ряд других общих правил, предусмотренных ст. 164 УПК РФ, которые вполне применимы к мероприятиям доследственной проверки.

По второму виду систематизации (в случае отказа в возбуждении уголовного дела) на практике применяется метод, аналогичный описанному в п. 1: материалы систематизируются в хронологическом порядке, в той же последовательности, но с одной особенностью. Очень часто следователи, дознаватели первым документом материала подшивают постановление об отказе в возбуждении уголовного дела. В целом это вполне удобно для лица, изучающего или проверяющего материал, поскольку открыв подшивку (том), сразу можно увидеть документ о принятом правовом решении. Однако в случае, если прокурор (п.п. 2, 6 ч. 2 ст. 37 УПК РФ) или руководитель следственного органа (п. 2 ч. ст. 39 УПК РФ), изучив материал, отменят решение об отказе в возбуждении уголовного дела и направят материал для дополнительной проверки, его придется полностью перенумеровывать, переподшивать и делать новую опись. Поэтому разумнее подшивать это постановление в конце материала. Правовых препятствий ни к тому, ни к другому способу систематизации нет. В любом случае, после постановления об отказе в возбуждении уголовного дела в обязательном порядке подшивается уведомление заявителю о принятом правовом решении.

Учитывая, что систематизация и подшивка «отказного» материала не представляет особой сложности, поручить данную работу можно общественному помощнику. Кроме того, учитывая, что значительная часть постановлений об отказе в возбуждении уголовного дела, в особенности в практике районных ОВД, однотипны, то общественный помощник вполне может воспользоваться имеющимися у любого следователя или дознавателя примерами постановлений и подготовить его проект.

Следователь и дознаватель при принятии решения об отказе в возбуждении уголовного дела обязаны соблюдать требования ст.ст. 144 145 УПК РФ. Постановление об отказе в возбуждении уголовного дела должно содержать информацию о наличии оснований для принятия этого правового решения, а также ссылки на отдельные документы их материалов проверки, значимые для принятия этого решения (объяснения лиц, акты проверок или ревизий, иные документы и т.д.), с указанием соответствующих листов материала.
Глава 5

\section{ОБЩЕСТВЕННЫЕ ПОМОЩНИКИ И ПРАКТИКАНТЫ КАК ПОНЯТЫЕ И СПЕЦИАЛИСТЫ: ЗА И ПРОТИВ}

Для максимально глубокого, всестороннего и результативного изучения работы следователя общественному помощнику и практиканту необходимо активно участвовать в проводимых им следственных действиях. Но, к сожалению, ни тот ни другой в уголовном судопроизводстве не имеет никакого процессуального статуса. Это создает серьезные сложности в практической деятельности.

В частности, следователям ежедневно требуется участие понятых, причем граждан, соответствующих целому ряду нормативных требований, и притом добросовестных, способных выделить время на процессуальные действия, запомнить все уведенное и при необходимости дать правдивые показания на следствии и в суде. С каждым годом найти таких порядочных граждан просто «на улице» становиться все труднее. Велик, очень велик соблазн следователя и оперативника не мучиться в поисках, не рисковать с бомжами и пьяницами, а взять на следственное действие своего надежного младшего товарища - общественного помощника или практиканта.

Но жизнь следователей в этой части только усложняется. Так, п. 22 Положения об общественном помощнике следователя ${ }^{25}$ прямо запрешает привлечение последнего в качестве участника уголовного судопроизводства (эксперта, специалиста, переводчика, понятого).

Как известно, в соответствии с ч. 1 ст. 60 УПК РФ понятым является лицо, не заинтересованное в исходе дела, привлекаемое дознавателем, следователем для удостоверения факта производства следственного действия, его содержания, хода и результатов. Вообще ч. 2 ст. 60 УПК РФ, устанавливающая для отдельных категорий лиц прямые запреты на участие в качестве понятых, указаний на практикантов не содержит. Но все дело в толковании фразы «лицо, не заинтересованное в исходе дела». Оно, толкование, в практике бывает весьма широким и/или противоречивым.

Заметим, что в названном Положении речь идет не о практикантах, а только об общественных помощниках - лицах, имеющих особый правовой (но не процессуальный) статус, специальное удостоверение

${ }^{25}$ См. Приложение 1. 
(п. 13) и шанс попасть в кадровый резерв (п. 2 Положения). Очевидно, что председатель Следственного комитета прав - общественного помощника можно признать заинтересованным лицом.

Но как быть с лицом, не имеющим никакого правового статуса - со студентом-практикантом? С одной стороны, если он не является родственником обвиняемого, потерпевшего либо свидетелей по делу, он не может быть прямо заинтересован в результатах проведенного следственного действия.

С другой стороны, по конкретным делам сторона защиты часто подает жалобы и заявляет ходатайства, убеждая суд в том, что студент при прохождении практики находится в зависимом положении от лица, осуществляющего предварительное следствие по делу. Ведь следователь является непосредственным руководителем по практике. В его полномочия входит утверждение соответствующего отчета, выдача характеристики практиканта. Студент, так же, как и общественный помощник, часто рассчитывает позднее быть принятым на работу в орган, где он проходил практику. Суды очень часто соглашаются с такой позицией и признают соответствующие, порой ключевые доказательства, недопустимыми. Это катастрофа для стороны обвинения.

Как ее предотвратить?

1. Жесткий вариант: полностью исключить использование не только общественных помощников, но и любых практикантов в качестве понятых.

2. Мягкий вариант: привлекать в качестве понятых только тех практикантов, которые находятся под кураторством других следователей, в другом органе. Например, следователь межрайонного следственного отдела СУ СК может попросить направить ему практикантов из следственного отдела РОВД.

Уважаемые следователи! Какой вариант выбрать, жесткий или мягкий, решать вам, но только по согласованию с руководством и с учетом сложившейся в вашем регионе судебной практики.

3. Беспроигрышный вариант. Можно требовать от практикантов, чтобы они находили для участия в качестве понятых своих знакомых, удовлетворяющих требованиям ст. 60 УПК РФ.

Кроме того, не видим препятствий к тому, чтобы привлекать практикантов (но не общественных помощников) к участию в следственных действиях в качестве иного участника уголовного судопроизводства - специалиста. В соответствии с ч. 1 ст. 58 УПК РФ специалистом является лицо, обладаюшее специальными знаниями, привлекаемое к участию в процессуальных действиях для содействия в обнаружении, закреплении и изъятии предметов и документов, применении технических средств в исследовании материалов уголовного дела, постановки вопросов эксперту, а также разъяснения сторонам и суду вопросов, входящих в его профессиональную компетенцию.

Кто обладает специальными познаниями, а кто нет, - решает следователь. Практикант может оказаться лицом, обладающим специальными познаниями в области применения технических средств: аудио-, видеозаписи, фотографирования, измерения и др. Учитывая, что с такими задачами способен справиться практически любой студент, у суда редко возникают сомнения в допустимости практиканта в качестве специалиста. В этом качестве он может участвовать при проведении следующих следственных действий:

- осмотра места происшествия и трупа;

- осмотра предметов;

- проверки показаний на месте;

- следственного эксперимента;

- задержания;

- допроса свидетелей, потерпевших, подозреваемых и обвиняемых;

- очной ставки и других ${ }^{26}$.

Порядок и условия использования помощи помощника и практиканта в качестве специалиста приведены в гл.гл. 7, 10, 11. ${ }^{26}$ Примеры этих и других процессуальных документов размещены на сайте labatr.bsu.ru,
ссылка на данное руководство, электронное приложение № 5. Подробнее см. 1.4. 


\section{Глава 6}

\section{ОБЩЕСТВЕННЫЙ ПОМОЩНИК \\ И ПРАКТИКАНТ В ПЛАНИРОВАНИИ И ОРГАНИЗАЦИИ РАБОТЫ СЛЕДОВАТЕЛЯ}

Уважаемые коллеги - следователи! В рамках настоящего исследования было установлено, что в среднем от 20 до $60 \%$ рабочего времени следователь в зависимости от опыта работы может тратить совершенно напрасно в результате ошибок в планировании и недостатков организации своей работы.

И в этом, казалось бы, столь личном вопросе общественный помощник или практикант может оказать посильную помощь. Изложенные ниже рекомендации позволят им стать кем-то вроде личного менеджера практического работника, сэкономив ему тем самым массу времени и помогая на качественном уровне выполнять профессиональные обязанности.

Для начала и следователям, и их помощникам, практикантам настоятельно рекомендуем изучить литературу по научной организации труда (НОТ) следователя ${ }^{27}$, а также по тайм-менеджменту - современной науке управления временем ${ }^{28}$. Эти знания очень важны и активно внедряются в бизнесе, в органах власти и управления, но пока, к сожалению, почти не востребованы следователями. Напрасно, потому что эти знания позволяют с максимальной эффективностью организовать рабочее время и время отдыха, выстроить личную мотивацию и целеполагание, лучше планировать, расставлять приоритеты, эффективнее читать, делегировать полномочия и мн. др.

\section{1. Общие вопросы}

Планирование рабочего времени следователя в широком понимании означает не только планирование предварительного расследова-

\footnotetext{
${ }^{27}$ См., например: Порубов Н.И. Научная организация труда следователя. Минск: Вышэйш. шк., 1970. С. 46.

${ }^{28}$ См., например: Архангельский Г.А. Тайм-драйв: Как успевать жить и работать. 5-е изд. М.: Манн, Иванов и Фербер, 2007. 256 с. (в Интернете имеются электронные версии книги, а также много статей. О законности их размешения в сети нам не известно. Прим. отв. ред.).
}

ния по имеющимся в производстве уголовным делам, но и планирование решения всех других задач, возникающих в ходе выполнения работы. Так, планирование без учета дежурств, разрешения материалов в порядке ст.ст. 144-145 УПК РФ, повышения профессиональной квалификации, участия в совещаниях, наставничества и т.д. не позволит качественно и в срок выполнить всю работу.

Кроме того, приходится учитывать и разные непредвиденные обстоятельства. Только нерадивый следователь не старается их учесть. Так, в ходе подготовки к предъявлению окончательного обвинения надо предусмотреть вероятность того, что не явится адвокат, в следственном изоляторе потеряют требование о вывозе арестованного обвиняемого и т.п. В конце концов, самого следователя могут срочно направить на неожиданное происшествие.

За 5 суток до выполнения процессуального действия нужно направить уведомление адвокатам в юридические консультации, а также вручить уведомление им лично. Поручите это своему общественному помощнику или практиканту.

Вам известно, что дату предъявления окончательного обвинения не следует назначать в последние дни срока следствия и содержания под стражей, чтобы была возможность в экстренной ситуации перенести предъявление обвинения на более поздний срок. При необходимости следует заблаговременно продлить процессуальные сроки.

Если сроки по делу уже продлевались, общественному помощнику (практиканту) легче будет составить документы по «продленке». Вы лишь проверите, дополните, поправите, подпишите.

За сутки до начала следственного действия нужно позвонить в спецчасть следственного изолятора и выяснить, запланирован ли вывоз (этап) следственно-арестованного (подготовлено ли его личное дело) и есть ли обстоятельства, препятствующие этому (например, следственноарестованный заболел или его вывозят по другому делу и т.д.). Это тоже можно поручить помощнику (практиканту).

При наличии угрозы незапланированного (вместо дежурного следователя) выезда на место происшествия можно поступить следующим образом. Не затягивать с выполнением следственных действий. Всегда сидящий рядом помощник (практикант) должен предупреждать допрашиваемых о возможном срыве выполнения следственного действия и просить перед явкой в прокуратуру (ОВД) созвониться со следователем, а в случае срыва следственного действия явиться в заранее указанный следователем день и время. 


\section{2. Рабочее место}

С чего начинать? Прежде всего с рабочего места. Все в кабинете должно не отвлекать, а помогать в повседневной работе. У каждого следователя в обязательном порядке должны быть УК РФ, УПК РФ, несколько разных комментариев к кодексам, другие НПА ${ }^{29}$, необходимая юридическая литература. Эти источники могут быть и в электронном варианте, но «бумажные» книги все же рекомендуем иметь.

Пусть помощник (практикант) проверит, все ли имеется у вас из необходимого списка, все ли НПА действуюшие, нужны ли вкладыши с изменениями или лучше купить (скачать в Интернете) новое издание, вся ли литература закуплена, получена в библиотеке? Если нет, его дорога в книжный магазин (библиотеку), в место доступа к СПС «Консультант Плюс» («Гарант» и др.).

В компьютере не должно быть отвлекающих программ (компьютерные игры и т.д.). У некоторых следователей нет никакой системы собирания служебной информации в персональном компьютере. Поэтому следователь часто тратит свое рабочее время не на решение поставленных задач, а на поиск полезной и нужной информации. По данной тематике составлены методические рекомендации «Если следователь «на Вы» с компьютером...» (гл. 8). Следует иметь в виду, что у подавляющего большинства нынешних общественных помощников и практикантов дома есть личные компьютенры, при этом, чаще всего, более современные, чем рабочие. Это значит, что:

- он может поделиться полезными программами и ресурсами ${ }^{30}$;

- у него, наверняка, есть знакомый программист или продвинутый юзер, который поможет в настройках, ремонте компьютера, оснащении программами и т.п.;

- он, если вы ему доверяете, в ваше отсутствие может заняться такими полезными делами, как дефрагментация жесткого диска, проверка компьютера на вирусы, систематизация файлов и папок и т.п.

Затем следует поручить студенту подготовить ваш следственный дежурный чемодан. Зачастую следователи формируют его без особой тщательности. Поэтому, выехав на место происшествия, многие не всегда быстро могут найти в чемоданчике нужный документ или вообще его не находят. Таким образом, нерационально тратится ра-

${ }_{29}$ Все НПА должны быть обязательно в действующих редакциях.

${ }^{30}$ Если это не связано с незаконным использованием объектов авторского права. См., например, ст. 146 УК РФ. бочее время. Упускается возможность оперативно и качественно выполнить неотложные следственные действия.

\section{3. Планирование работы}

Следующим этапом является планирование рабочего времени следователя. Рекомендуем ставить себе задачи как минимум на месяц вперед. Следует систематически проводить ревизию имеющихся в производстве уголовных дел, выяснять, на какой стадии они находятся. Контролировать количество неразрешенных материалов проверок, количество дней, необходимых для дежурства, стажировок, обучения, командировок и т.д.

Первичную информацию для этого (справки о сроках, субъектах, фабулах и т.п.) может и должен готовить общественный помощник (практикант). Распределить задачи, подлежащие разрешению, следует сначала по месяцам, потом по дням и часам. Необходимо, чтобы запланированные мероприятия не пересекались между собой, по возможности не попадали на выходные, праздничные и дежурные дни. По каждому уголовному делу нужно своевременно составить подробный план предварительного расследования, который порой следует утвердить у руководителя следственного органа. Образцы планов предварительного следствия по уголовным делам в качестве приложения к УПК РФ не существуют. Но тем не менее многие следователи умело планируют свою работу. Отправьте к ним практиканта, пусть он найдет примеры планов.

Приведем некоторые фрагменты таковых ${ }^{31}$. Чтобы сэкономить драгоценное время, составлять соответствующие таблицы (форму), а также продумать содержание некоторых граф может и должен именно практикант.

\section{По уголовному делу \\ ПЛАН РАССЛЕДОВАНИЯ}

\section{Дата возбуждения дела}

Дата принятия дела к производству

Обвинение предъявлено

По делу арестован(ы)

Срок окончания расследования

Исходныө данные

Следственные версии

A

B

РАЗДЕЛ I

${ }^{1}$ Примеры планов размещены на сайте labatr.bsu.ru, ссылка на данное руководство, электронное приложение № 6. Подробнее см. 1.4. 


\begin{tabular}{|c|c|c|c|c|}
\hline $\begin{array}{c}\text { Boпросы и обстоя- } \\
\text { тельства, общие } \\
\text { Аля всех версий }\end{array}$ & $\begin{array}{c}\text { Следственные, } \\
\text { оперативно- } \\
\text { розыскные и иные } \\
\text { действия }\end{array}$ & Срок & $\begin{array}{c}\text { Испфлни- } \\
\text { тель }\end{array}$ & $\begin{array}{c}\text { Отметки о } \\
\text { выполнении } \\
\text { и рөзультат }\end{array}$ \\
\hline & & & & \\
\hline
\end{tabular}

РАЗДЕЛ II

Версия A

\begin{tabular}{|c|c|c|c|c|c|}
\hline \multicolumn{2}{|c|}{ Выяснить } & \multirow{2}{*}{$\begin{array}{c}\text { Следственные, } \\
\text { оперативно- } \\
\text { розыскные } \\
\text { и иные действия } \\
\end{array}$} & \multirow[t]{2}{*}{ Cpok } & \multirow{2}{*}{$\begin{array}{l}\text { Испол- } \\
\text { нитель }\end{array}$} & \multirow{2}{*}{$\begin{array}{l}\text { Отметки } \\
\text { о выпол- } \\
\text { нении и } \\
\text { результат }\end{array}$} \\
\hline $\begin{array}{l}\text { Вопросы } \\
\text { по вөрсии }\end{array}$ & $\begin{array}{l}\text { Обстоятельства } \\
\text { в связи с добы- } \\
\text { тыми данными }\end{array}$ & & & & \\
\hline & & & & & \\
\hline
\end{tabular}

То же по версиям Б и $\mathrm{B}$

\section{Примерный план допроса свидетеля ${ }^{32}$}

(фамилия, имя, отчество)

\begin{tabular}{|c|c|}
\hline $\begin{array}{c}\text { Исходная информация: } \\
\text { Какие обстоятельства не выяснены у свиде- } \\
\text { теля, нуждаются в уточнении; какие новые } \\
\text { данные получены после первичного допроса, } \\
\text { где они изложены (лист, дело), их содержание }\end{array}$ & $\begin{array}{c}\text { Какие обстоятельства } \\
\text { вопросы ему поставить }\end{array}$ \\
\hline & \\
\hline & \\
\hline & \\
\hline & \\
\hline
\end{tabular}

В ходе допроса получены данные о ранее неизвестных свидетелях

(фамилия, имя, отчество,

место жительства, место работы, кличка, приметы, др. данные,

необходимые для установления свидетеля и его вызова)

${ }_{32}$ Криминалистика: учебник / Отв. ред. Н.П. Яблоков. Изд. 2-е, перераб. и доп. М.: Юристь, 2001. С. 105.
По результатам допроса необходимо провести такие-то следственные действия, послать запросы, отдельные поручения

Примечание: приведенные планы применимы и при допросах потерпевшего, подозреваемого, обвиняемого; у подозреваемого, обвиняемого в обязательном порядке выясняются его версия, доводы в свою защиту; при допросе следует определить, не нужно ли поставить допрашиваемому контрольные вопросы; после записи показаний проверить, нет ли неясностей, противоречий, фраз, допускающих двоякое толкование; при повторном допросе проверить, соответствуют ли показания допрашиваемого ранее им данным, при наличии противоречий выяснить причину; если при повторном допросе допрашиваемый сообщил новые обстоятельства, выяснить, почему ранее о них не давал показаний; при противоречии показаний допрашиваемого показаниям других лиц оглашение показаний последних допрашиваемому недопустимо.

\begin{tabular}{|c|c|}
\hline Версии & Что необходимо выяснить \\
\hline Исходная информация & \\
\hline & \\
\hline & \\
\hline
\end{tabular}

\begin{tabular}{|c|c|c|}
\hline $\begin{array}{c}\text { Какие следственные действия } \\
\text { необходимо произвести }\end{array}$ & $\begin{array}{c}\text { Сроки } \\
\text { проведения }\end{array}$ & $\begin{array}{c}\text { Отметка } \\
\text { о выполнении }\end{array}$ \\
\hline & & \\
\hline & & \\
\hline
\end{tabular}

\begin{tabular}{|c|c|c|c|c|c|}
\hline \multicolumn{6}{|c|}{ Наименование следственных действий } \\
\hline 《___ "- & $200 \_$г & «___ & $200 \_$_. & "__ " & $0 \_$r. \\
\hline & часы & & часы & & часы \\
\hline & & & & & \\
\hline & & & & & \\
\hline & & & & & \\
\hline & & & & & \\
\hline
\end{tabular}


В ходе составления плана расследования по уголовному делу главное не форма, а содержание. Поэтому не следует придерживаться каких-либо шаблонов. План должен составляться в зависимости от индивидуальных данных конкретного уголовного дела. Так, если надо сделать какой-либо анализ по нему, это можно сделать именно в плане. В нем отражается все, что следователю стало известно по уголовному делу. Например, какие версии выдвинуты, что именно изъято, в ходе каких следственных действий, где хранится, осмотрено ли и т.д. Также учитывается, кто допрошен, какое отношение допрошенный имеет к делу, кто не допрошен, как его найти, по какому поводу и кого именно допросить, кто потерпевший, подозреваемый, адвокат, их анкетные данные, контактные телефоны и мн. др. Для составления плана может пригодиться перечень, приведенный в гл. 15 «Как помочь в проверке материалов уголовного дела». Возьмите пункты имеющихся там перечней и введите их в свой план.

Вряд ли общественный помощник (практикант) сразу справится с поручением составить план. Да и не знает он поначалу всех обстоятельств дела. Но поручите это ему как первое сложное задание. Пусть составляет план в электронном виде. Если хоть что-то в нем будет полезно, возьмете за основу и доработаете. А молодой человек будет горд, что он помог в святая святых следственного таинства - в планировании!

Когда план расследования составлен на высоком профессиональном уровне, при передаче дела от одного следователя к другому последнему достаточно прочитать этот документ и уголовное дело, чтобы владеть полной информацией по делу. Что происходит в действительности? При передаче уголовного дела новый следователь старается выслушать прежнего, который рассказывает о том, чего в действительности в деле нет. Например, прежнему следователю устно стало известно о новых свидетелях, местонахождении вещественных доказательств или о новых обстоятельствах совершенного преступления, а в уголовном деле (как в материалах, так и плане) этих сведений нет.

В каждом случае передачи вашего дела куда-либо направляйте с ним своего помощника, работавшего по нему. Попросите помочь коллеге более полно и быстро вникнуть в суть дела.

Следователь, легкомысленно надеясь сэкономить свое рабочее время на стадии планирования расследования, позднее систематически теряет драгоценные часы, дни и недели на устранение пробелов и ошибок, явившихся результатом ненадлежащего подхода. К планированию не следует относиться как к чему-то статическому и инертному. Грамотный следователь постоянно, систематически обращается к плану.
Он дополняет и изменяет его в зависимости от выполнения следственных действий и поступившей новой полезной информации.

Планируя уголовное дело в целом, следует также планировать и каждое следственное действие в отдельности. Это можно делать как в общем плане, так и, например, в рамках плана допроса, где приводятся вопросы, подлежащие выяснению.

Во все эти мероприятия можно и нужно задействовать помощника или практиканта. Пусть учится анализировать дела, планировать мероприятия, составлять проекты документов, подсказывать вам упущенные детали, наконец, просто быстро печатать и составлять таблицы. Вместе с тем у каждого следователя свои подходы к составлению планов расследования, допросов, других следственных действий. Поэтому помощнику следует ознакомиться с несколькими готовыми планами куратора по другим делам, их структурой и т.п. ${ }^{33}$

Многие следователи для организации своей работы, помимо письменного плана (или электронного), пользуются «календарями», «планировщиками» и другими программами в своих мобильных устройствах: телефонах, смартфонах, коммуникаторах. «Забивать» вручную задачи, заметки и контакты довольно долго. Если доверяете, попробуйте поручить эти вопросы своему помощнику. При этом не забывайте, что большинство современных мобильных устройств позволяют, например, вводить информацию на компьютер и с помощью специальных программ синхронизации переносить ее на гаджет.

\section{4. «Маячки»}

Кроме составления планов предварительного расследования по уголовным делам, целесообразно поместить на обложку уголовного дела или вложить в него стандартный лист белой бумаги. Там необходимо записывать все те новые сведения по делу, которые возникают в ходе ежедневной работы и не включены в план.

Когда по уголовному делу появляется какая-либо информация, требующая проверки или реализации (исполнения), следует обязательно записать это на упомянутом листе. Это будет своеобразным «маячком», не позволяющим забыть записанные мероприятия или сведения, его следует заводить еше до составления плана расследования.

\footnotetext{
${ }_{33}^{3}$ Примеры планов и других документов размещены на сайте labatr.bsu.ru, ссылка на данное
} руководство, электронное приложение № 6. Подробнее см. 1.4 . 
Указанный лист с записями целесообразно вложить в дело, но не подшивать. В течение всего следствия туда также записываются спонтанные, еше не попавшие в план мысли о том, что надо сделать для собирания дополнительных доказательств, исправления конкретных ошибок, окончания расследования. По мере выполнения задач, указанных на листе, они вычеркиваются. Тогда будет наглядно видно, что осталось сделать. При составлении дополнительного плана следствия информацию из листа с записями следует перенести в план. После этого данный лист с черновыми записями можно уничтожить. При этом заводится новый лист для черновых записей.

Приведем пример. Следователь вспомнил, что не запланировал какое-либо следственное действие; внезапно заметил какую-либо ошибку, требующую исправления; получил новую информацию (поменялся адвокат, его телефон, адрес, не явился какой-то свидетель и надо подготовить поручение и привод, назначить экспертизу по вновь избятому вещественному доказательству и т.д.). Записав упомянутое в черновик, следователь в последующем в ежедневной суете не забудет о важных, не запланированных ранее мероприятиях. Надо делать так, чтобы черновик плана был всегда на виду. Это форма самоконтроля позволяет ничего не упустить и не забыть независимо от загруженности.

Кроме того, следователь обязан приучить себя вкладывать в дело, но не подшивать документы о незаконченных следственных действиях (где следует получить чью-то подпись, заполнить какие-либо графы и т.д.) Тогда следователь также постоянно будет видеть свои недоработки и в последующем найдет время их исправить. Если следователь понадеется только на память и подошьет документ о следственном, ином процессуальном действии, которое до конца не оформлено, в последующем он рискует так и оставить его неоконченным до истечения сроков.

\section{5. Приоритеты}

Следующим важным фактором в планировании рабочего времени следователя являются так называемые приоритеты. Всегда встает вопрос, какое уголовное дело расследовать в первую очередь, какое следственное действие выполнить сегодня, а какое завтра и т.п.

Каждый следователь регулярно должен совершать один и тот же «ритуал». Получив новое уголовное дело, независимо от загруженности, нужно сначала изучить его, после чего уже принимать к производству. Ничто не должно отвлекать следователя от этой важной процедуры.
Затем необходимо решить, какие следственные действия невозможно выполнить незамедлительно, а какие выполняются длительное время независимо от следователя. Также следует разделить, какие мероприятия можно выполнить, не выходя из кабинета, а какие только с выездом на место. Так, если своевременно не назначить экспертизу, не направить отдельное поручение по делу в другой регион (страну), не запросить характеризующий материал и иные необходимые сведения, то в более поздний период восполнить это будет трудно, а зачастую и невозможно.

При этом допросы свидетелей, потерпевших, многие осмотры, обыски, выемки и т.д. можно и нужно провести незамедлительно, при наличии как запланированного, так и незапланированного рабочего времени, а порой и в нерабочее время. Поэтому, получив в производство новое уголовное дело, в первую очередь необходимо назначить эКспертизы, направить запросы и поручения.

Если время позволяет, поручите составить все документы в проектах общественному помощнику, практиканту. Образцы дайте сами из своих законченных производством дел, желательно в электронном виде. Далее нужно только контролировать исполнение поручения и своевременное направление документов. Здесь же поручите помощнику при необходимости посылать напоминания адресатам.

Рекомендуем также в той или иной форме оформлять «памятки» с указанием лиц, которых следует допросить, но сделать это не удалось (неявка на допрос, болезнь, иные причины). Для чего это нужно? Со временем у следователя «скопятся» невыполненные процессуальные действия, которые можно исполнить только лично и только с выездом. При этом со временем часть запросов, памяток будет исполнена без особых усилий (запрос исполнят, свидетель внезапно явится и т.п.). Останутся только «безнадежные» запросы и мероприятия. Как их исполнять? Какие дни выделять? Многие в своей следственной практике все для «личного исполнения» осуществляют с выездом на место, выбирая следующее время. Во-первых, это конец рабочего дня. Вечером люди чаще бывают дома и их легче найти. Во-вторых, это выходные и праздничные дни. Их преимущество не только в том, что легче найти людей, проходящих по делу. В случае их отсутствия можно опросить или допросить соседей по поводу необходимых сведений об отсутствующем свидетеле, подозреваемом, потерпевшем. В-третьих, можно выделить часть рабочего дня для работы за пределами кабинета.

Часто звонят исполнители и сообщают, что ответ необходимо забрать нарочным или времени для подготовки и направления ответа недостаточно, укажет конкретное время. В этом случае копию соответствую- 
шего запроса можно отдать практиканту или водителю отдела, который ежедневно развозит почту. Тот заедет к адресату и получит ответ.

Если вы работаете в выходной день, то можно и нужно использовать его для планирования, разбора полученной почты, ее распределения по уголовным делам, систематизации, подшивания материалов уголовных дел и т.д. Соберитесь для этих целей вместе с помощником, практикантом. Первое, как правило, оставьте себе, остальное - им. При таком организационном подходе никто не отвлечет вашу команду от планирования следующей недели, просмотра всех уголовных дел и самоконтроля. Обычно на указанные мероприятия в выходной день достаточно затратить от 2 до 4 часов. Но эти несколько часов позволяют в течение недели не работать в авральном режиме, а держать на контроле все дела и материалы, не допуская по ним волокиту и нарушения норм УПК РФ. Приняв к производству дело, после его внимательнейшего изучения следует поручить помощнику, а лучшее менее квалифицированному лицу - практиканту, незамедлительно направить повестки всем лицам, которых необходимо допросить.

\section{6. Повестки и допросы}

Часто бывает, что когда практикант сам приносит повестки, вызываемые не принимают его всерьез. У общественных помощников следователей Следственного комитета при прокуратуре РФ теперь есть удостоверения утвержденного образца ${ }^{34}$. Но у практикантов нет никаких официальных правоустанавливающих документов. Прежде всего следует проинструктировать практиканта как вести себя с вызываемым. Быть может стоит выдать ему официальную справку с указанием на прохождение практики либо на время этих «официальных визитов» направить в помощь ему сотрудника милиции, например, постового милиционера.

Часто бывает, что общественные помощники, практиканты, оказавшись одни в «неблагополучных» районах по поручению следователя, не только не могут его исполнить, но и сами становятся потерпевшими Следователям нужно всегда помнить, что ни в коем случае нельзя подвергать риску жизнь, здоровье, имущество помощника и практиканта.

При оформлении всех бланков повесток поручите молодежи указывать на каждой контактные телефоны. На обратной стороне листка желательно указать не только адрес и описание того, как можно добраться

\footnotetext{
${ }^{34} \mathrm{~K}$ Положению об общественном помощнике следователя прилагается образец такого удостоверения. См. Приложение 1.
}

до следственного отдела. Например, некоторые следователи рисуют и затем сканируют схему расположения отдела и ближайших остановок общественного транспорта. При распечатывании повестки схема размещается на обратной стороне. Это очень удобно для граждан, позволяет им без опозданий и затруднений прибыть по вызову.

Для допроса необходимо выбрать определенный день - примерно через две недели со дня отправления повесток почтой. Затем помощнику, практиканту следует поручить составить и приобщить к каждому делу справку, где указать, кому именно направлены повестки, каким именно способом (почтой или нарочным), на какую дату и время.

Всегда в течение указанных двух недель часть вызываемых лиц, получив повестки, позвонит следователю. При этом одна часть граждан попросит перенести следственное действие ввиду занятости. Другая часть лиц заявит о невозможности явки из-за материальных затруднений, болезни, пожилого возраста и по другим причинам. Остальные свидетели в указанный в повестке день явятся на допрос. Позднее, по истечении двух недель со дня отправления повесток, следователю станет ясно:

- кто на допрос пришел;

- кто явится позднее и в какой день;

- к кому придется направлять сначала практиканта, затем участкового;

- в отношении кого выносить постановление о приводе;

- к кому придется направлять лицо, уполномоченное вами допросить свидетеля (пожилой возраст, болезнь и т.д.) ${ }^{35}$;

- к кому придется ехать лично для производства допроса.

При неисполнении назначенного привода свидетеля в порядке контроля целесообразно направить практиканта по месту его жительства. Бывает так, что милиционеры, уполномоченные осуществить привод, без выезда на место составляют справку о том, что якобы «дверь никто не открыл» или «там никто не проживает».

Когда возникает необходимость вызвать большое количество свидетелей, есть вероятность, что они все явятся по повесткам в одно время. Следует часть свидетелей вызывать последовательно с 8 или 9 часов и далее до обеда, а другую часть - с 14 часов и далее до вечера того же дня. Так, у следователя появится возможность равномерно в течение всего дня допрашивать вызванных лиц

\footnotetext{
${ }_{35}^{35}$ Многие следователи используют для этого помощь практикантов. Но не следует забывать, что они ненадежашие субъекты проведения следственного действия. Не получится ли так, что адвокат позднее поставит вопрос о недопустимости доказательства? Вам решать, вы предупреждены.
} 
Зарекомендовала себя и такая практика допроса. Относится она к лицам, не являющимся подозреваемыми и обвиняемыми, ключевыми свидетелями, потерпевшими ${ }^{36}$. Как правило, это различные свидетели, например, дающие сходные показания. Следователь допрашивает их устно в присутствии общественного помощника, практиканта. После этого последние составляют проект протокола без заключительной записи допрашиваемого: «Мною прочитано, с моих слов записано верно». Следователь проверяет документ. Если все правильно, нет дополнений и уточнений, он лично завершает допрос ${ }^{37}$. Не лишним будет напомнить, что часто выполненные на компьютере протоколы допросы свидетелей, дающих сходные показания, полностью совпадают по тексту. Такой «копировальный» подход часто и не без оснований вызывает сомнения судов в допустимости соответствующих доказательств.

Есть еше одно правило, касающееся выезда на место происшествия. Сразу после совершения преступления и выезда следователя, следственно-оперативной группы, все взволнованы происшедшим и легко идут на контакт. Это надо умело использовать. По возможности нужно допросить максимальное количество свидетелей и очевидцев уже на месте происшествия. Оставшихся не допрошенными нужно вызвать повестками на следующий день. Нерадивые следователи этим иногда пренебрегают. Позднее люди успокаиваются и от допросов уклоняются.

Надо взять за правило каждую неделю по каждому уголовному делу проводить следственные действия. И пусть это контролирует один помощник или практикант. Если этого не делать, а увлечься только каким-то одним уголовным делом, понадеяться на то, что в конце срока предварительного расследования неприоритетного уголовного дела вы все якобы успеете выполнить, поверьте, в оставшиеся сроки вы обязательно столкнетесь с невозможностью обеспечить полноту и всесторонность расследования. О нежелательных последствиях умолчим... Разве нужны комментарии?

${ }^{36}$ Таких лиц следователю, как правило, все же следует допрашивать лично от начала и до конца следственного действия.

${ }^{37}$ Давая такую рекомендацию, следует предупредить, что такая практика является спорной и во многом рискованной. Некоторые судьи подобные протоколы исключают из объема доказательств. Их позиция: протокол должен быть составлен лицом, обладающим на то процессуальными полномочиями. Кроме того, в суде будет сложно опровергнуть вероятные доводы зашиты о том, что следователь на допросе не присутствовал, а только потом подписал протокол. Перед применением этой рекомендации следует посоветоваться с курирующим следователем и руководителем СО (Прим. отв. ред.).

\section{7. Шаблоны}

Вновь отметим: когда следователь стремится качественно и в срок расследовать уголовные дела, ему приходится выбирать приоритеты. Приходится делить следственные действия на те, которые можно выполнить и составить документы шаблонно, по ранее разработанному электронному образцу, и на те, которые требуют индивидуального, тщательно продуманного подхода.

Шаблон обычно разрабатывается и применяется для запросов, осмотров предметов и документов - второстепенных вещественных доказательств, допросов понятых и т.д., где особой тщательности и творческого подхода не требуется ${ }^{38}$.

Многие опытные следователи считают, что при наличии возможности следует применять шаблон, нежели снова и снова «изобретать велосипед». Преимушества такого подхода очевидны. Следователь экономит рабочее и личное время, часто оберегает себя от различных технических, процессуальных и иных ошибок, ведь шаблоны заранее продуманы и отредактированы. Так, до создания директории, где компьютер самостоятельно по команде следователя заполняет весь блок запросов по характеризующему материалу на потерпевшего и обвиняемого, приходилось длительное время затрачивать на подготовку упомянутых запросов.

Следователь, применяя шаблоны, тем самым увеличивает время для интеллектуальной, творческой работы, планирования расследования и выполнения сложных следственных действий (составления обвинения, допросов, назначения экспертиз и т.д.). Рекомендуем поручить составление и систематизацию шаблонов общественному помощнику или практиканту. Время для выполнения этих заданий вы можете выбирать, когда сами не работаете на компьютере.

Многие следователи применяют шаблоны, скачивая их в электронном виде, например, из правовой системы «Консультант Плюс» (УПК РФ в редакции до 11.08.2007: статья 476. «Перечень бланков процессуальных документов досудебного производства»), а затем «забивая» в них личные реквизиты и т.п. Следует предупредить об опасности применения недействующей редакции кодекса. Эти бланки уже не являются частью уголовнопроцессуального закона, а потому многие их положения не соответствуют многочисленным изменениям, внесенным в УПК после 11.08.2007³9.

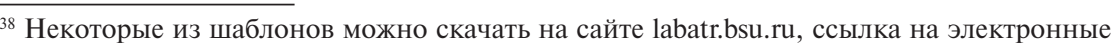
приложения к настоящему руководству.

${ }^{39}$ Некоторые шаблоны размещены на сайте labatr.bsu.ru, ссылка на данное руководство, электронные приложения № 2-13. Подробнее см. 1.4 .
} 


\section{Глава 7}

\section{РАБОТА НА МЕСТЕ ПРОИСШЕСТВИЯ}

Успешное раскрытие и расследование преступлений в значительной, а порой и в определяющей мере зависит от своевременного и умелого проведения осмотра места происшествия. Об этом знает любой, даже начинающий следователь. Но одно дело знать, а другое организовать и качественно провести это важное следственное действие. Учитывая его значимость, уделим ему особое внимание. Тем более что рекомендации следует сформулировать не только для следователей - этому учат многочисленные учебники и пособия ${ }^{40}$, но и для общественных помощников и практикантов, как правило, начинающих помогать следователям задолго до получения высшего юридического образования.

\section{1. Составление «памятки-бегунка» и пометка «вещдоков»}

Выехав на место происшествия, в первую очередь необходимо выяснить, что именно произошло. Надо поговорить с милиционерами, очевидцами и подозреваемым. Беседовать с ними следует с листком бумаги, где записываются все данные (фамилия, имя, отчество, домашний адрес) свидетелей, очевидцев, потерпевшего и подозреваемого. Кроме того, следует записать точный адрес места происшествия. В последуюшем этот листок бумаги с черновыми записями поможет более точно, детализированно провести допросы, установить и допросить иных свидетелей и т.д. Когда следователь только прибывает на место происшествия, люди часто еще толпятся вокруг. Если вовремя не сделать черновые записи, контакт с многими свидетелями и очевидцами будет навсегда утерян. Кроме того, имея под рукой черновик с данными всех лиц, имеющих отношение к совершенному преступлению, позднее легче допрашивать свидетелей, потерпевших, подозреваемых. В протоколе их допросов не будет беспомощных фраз типа: «...высокий брюнет, кажется, его зовут Петр...» и т.п., а указания на полные данные соответствуюших лиц и их адреса. Не трудно догадаться, что как раз

${ }^{40}$ Рекомендации этой главы ни в коем случае не подменяют их. Как уже отмечалось п. № 1.3, перед началом работы настоятельно рекомендуем прочитать соответствующие главы учебных изданий по криминалистике, уголовному процессу, уголовному праву. составление памятки-бегунка можно поручить вашему помощнику или добросовестному практиканту.

Внимание!Чтобы в дальнейшем в суде не встал вопрос о присутствии постороннего лица в ходе осмотра места происшествия, следует ввести в протокол данные об общественном помощнике (практиканте) как о лице, участвовавшем в следственном действии. Можно придать практиканту статус специалиста, одновременно поручив, например, фотографирование (см. 7.2).

Составив черновик с указанием всех лиц и адресов, его можно на время вручить милиционерам и оперативным работникам, которые будут делать поквартирный обход, допрашивать очевидцев. Скажите, чтобы нужные им сведения они переписали с черновика. Каждому милиционеру необходимо поставить конкретную задачу, как правило, до того, как следователь сам начнет осмотр и составление протокола. Далее, в ходе осмотра места происшествия иногда необходимо отвлекаться и выяснять, выполняет ли сотрудник милиции (иное лицо) поставленные перед ним задачи. К сожалению, исполнительская дисциплина в таких случаях не всегда на высоте.

Следующей целью предварительной беседы следователя с присутствующими является выяснение границ места происшествия, установление следов совершенного преступления, что именно и где произошло, какое орудие преступления следует отыскать и изъять. Обойдите место происшествия вместе с общественным помощником (практикантом) и, если доверяете, поручите ему составить черновую схему ${ }^{41}$ с отметками о важных деталях и т.п.

Не выполнив этого сразу, начав осмотр места происшествия, следователь не застрахован от ряда существенных ошибок. Например, есть риск увлечься осмотром территории или помещения, где ничего значимого не происходило, и при этом не хватит времени или внимания на ту часть помещения или территории, где было совершено преступление. А именно там, быть может, все особенно тщательно, до мелочей, следовало бы описать. Заранее зная, что необходимо закреплять в рамках данного следственного действия, следователь имеет возможность некоторые объекты подробно не описывать, а в протоколе кратко указать, например, так: «...в спальне, комнате № 2 общий порядок не нарушен, следов, относящихся к происшествию, не обнаружено...».

Разумеется, подробно следует описывать все следы совершенного преступления, их локализацию и место обнаружения. В последующем в ходе допросов необходимо дать оценку всему описанному и обна-

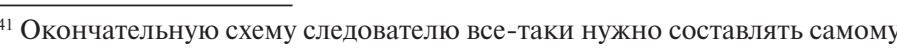


руженному. В показаниях должно быть объяснено все, что выявлено. В то же время детализированный осмотр позволяет изобличить лицо, давшее ложные показания. Это легко сделать, если внимательно выслушать показания и сравнить, сопоставить их с протоколом осмотра места происшествия (где, что и как происходило, как развивались события и т.д.). Следователь, допрашивая свидетеля без учета сведений из протокола осмотра места происшествия и других следственных действий, обрекает себя в будущем на дополнительные допросы в целях устранения противоречий или восполнения пробелов в показаниях.

По мере движения по месту происшествия и обнаружения вещественных доказательств их следует каким-либо образом помечать или изымать, помещать в пакеты и обязательно класть в упаковку пояснительную надпись, что это и где именно изъято. Позднее вы сделаете бирку с соответствующими надписями. Но в начале осмотра для этого времени нет. Достаточно положить в пакет только листок бумаги с черновыми записями по этому поводу.

Если этим пренебречь, в конце осмотра или после прибытия на рабочее место в прокуратуру по бирке с общим заглавием «вещественное доказательство» порой трудно будет вспомнить, что за предмет и где именно изъят, какое отношение он имеет к преступлению. Бывает ситуации и хуже, например, когда в одном кабинете путаются вещественные доказательства, изъятые по разным уголовным делам или материалам.

Задачу с пометками также можно поставить перед помощником и практикантом. Поручите им заранее заготовить листки бумаги. На месте происшествия вам останется только давать указания о том, что написать на каждом листке и куда его поместить. По окончании осмотра и проверки правильности упаковки можно доверить помощнику и практиканту опечатывание вешественных доказательств и получение подписей понятых (на упаковке).

Как уже отмечалось, обязательно следует составлять схему места происшествия. Обычно по мере выполнения следственного действия сначала составляются черновые схемы. Если местом происшествия является большой участок территории или квартира из нескольких комнат, всегда составляется схема определенной описанной части объекта, с указанием всех важных его особенностей и местом расположения изъятых предметов. Достаточно сделать крестик и кружок, а к нему провести стрелку, в начале которой написать, что именно обнаружено или находится там-то. Можно все обозначить цифрами, а в свободном месте листа в столбик привести условные обозначения с указанием, что там находится или обнаружено. По окончании осмотра на основе всех черновых схем следует составить общую схему места происшествия. Все составленные схемы, включая черновые, следует приобщить к протоколу осмотра места происшествия. Возможно они пригодятся во время последующих допросов. По окончании расследования, вероятно, в деле должна остаться лишь окончательная и полная схема.

Повторим, что составление черновых схем можно поручить помощнику или практиканту. Но не забудьте контролировать его. Иногда лучше просто диктовать то, что следует нанести на бумагу. Общую (окончательную) схему места происшествия лучше составить самому. Но добросовестный помощник или практикант после нескольких выездов может квалифицированно помочь и с этим.

Иногда целесообразно поручить помощнику наблюдать за поведением присутствующих при осмотре места происшествия лиц из числа возможных подозреваемых, свидетелей. Не исключены попытки противодействовать расследованию (уничтожить следы, припрятать вещественные доказательства и т.п.).

\section{2. Особенности фотосъемки места происшествия}

Уважаемый следователь! Очень хорошо, если всегда на место происшествия с вами выезжает специалист-профессионал, который возьмет на себя все задачи, связанные с фото-, видеосъемкой. Но давайте признаем, что бывает это, к сожалению, далеко не всегда. А нет специалиста - приходится фотографировать самому, теряя драгоценное время, отвлекаясь от организации следственного действия, розыска преступника, собственно осмотра, составления протокола. Иногда повезет - в следственно-оперативной группе, оцеплении найдется сотрудник, которому можно поручить это важное дело. Чаще всего, это оперуполномоченный, постовой милиционер или другие лица, в чьей технической подготовке и добросовестности порой приходится сомневаться. Последствия непрофессионального подхода к фотосъемке бывают самыми печальными: разряженная батарея, некачественные снимки, снимки не тех предметов, снятые не в тех ракурсах, а порой и вовсе уничтожение ценных кадров (случайное стирание и т.п.).

Мы предлагаем, быть может, не самый лучший, но все же более подходящий вариант, чем доверять фотосъемку постороннему. Совет в следующем: заранее подготовьте к этой работе своего общественного помощника или практиканта и затем делегируйте эту ответственную задачу именно ему. Предлагаем сделать это в следующем порядке: 
1. Для начала поручите изучить, перечитать заново учебную и учебнопрактическую литературу по криминалистической технике в целом и ее отрасли - криминалистической фотографии и видеозаписи, в частности ${ }^{42}$. Если считаете нужным, примите своеобразный зачет.

2. Направьте общественного помощника (практиканта) к опытному специалисту-профессионалу. Попросите провести дополнительный мастер-класс.

3. Заранее познакомьте общественного помощника, практиканта с соответствующей криминалистической техникой: служебным фотоаппаратом и видеокамерой, сменными объективами, кольцами, вспышками, штативами и т.п. Поручите внимательно изучить руководства к эксплуатации всех устройств и нести личную ответственность за их постоянную исправность и готовность к работе: следить за зарядом батарей, заполнением карты памяти на цифровом фотоаппарате и т.д.

4. Покажите общественному помощнику, практиканту типовой результат предстоящей работы - готовые фотографии (фототаблицы) к протоколам осмотра места происшествия по уголовным делам, законченным производством. Обучите оформлению фототаблиц и приложений. Расскажите о личных предпочтениях и пожеланиях.

5. Ознакомьте с содержанием этой главы.

Товарищ, пожалуй, готов! Берите его с собой на место происшествия. Только поначалу особенно тщательно контролируйте его работу.

Нам остается лишь обеспечить рекомендациями пятый пункт разъяснить некоторые важные положения, которые не всегда описаны в учебной литературе. Подробные рекомендации имеются в специализированных практических изданиях. Но поскольку они предназначены для экспертов и специалистов, они порой бывают довольно сложными для восприятия и слишком подробными.

Итак, напомним, что фотосъемка места происшествия как дополнительное средство фиксации обнаруженных объектов в некоторых случаях весьма затруднена. Это связано, во-первых, с тем, что на местности располагается большое количество разноудаленных от фотографируемого объектов; во-вторых, осмотр места происшествия - это неотложное следственное действие. Именно поэтому он часто проводится в условиях недостаточного освещения, либо в темное время суток и при искусственном освещении; в-третьих, в связи с уникальностью обста-

${ }_{42}$ Блейкер А. Применение фотографии в науке. М.: Мир, 1980. 321 с.; Ищенко П.П., Ищенко Е.П. Основы судебной фотографии, киносъемки и видеозаписи: учебное пособие. Екатеринбург: Изд-во Уральского госуниверситета, 1993. $431 \mathrm{c}$. новки, сложившейся на момент осмотра, повторное запечатление обстановки зачастую просто невозможно и, следовательно, требует применения особых приемов (методов) фотографирования. В учебниках криминалистики приводятся следующие приемы:

Круговая и линейная панорама. Цель - фиксация общих и крупных планов (например, взаимное положение обломков самолета, разрушения зданий в результате взрыва и т.д.). Детальные съемки выполняются с масштабной линейкой. При съемке оптическая ось объектива должна быть перпендикулярна плоскости предмета.

Встречная сбемка, при которой место происшествия или иной объект (труп, разрушенные здания и т.д.) фотографируется с двух противоположных сторон. Причем фотоаппарат поочередно располагается на обоих концах отрезка прямой, мысленно проведенного через место происшествия.

Крестообразная съемка. Место происшествия (или иной объект) мысленно заключается в квадрат (или прямоугольник), а фотоаппарат располагается в вершинах его углов. С помощью этого приема следует выполнять не только ориентирующие, обзорные, частично-обзорные снимки, но и обзорно-узловые, и узловые (например, снимки трупа, обломков самолета, вагонов и т.д.).

Фронтальная съемка - фотографирование объекта с центральной по отношению к нему точки.

Диагональная съемка - фотографирование с точки, смещенной от центральной. При такой съемке появляется возможность создания акцентов на тех объектах, которые важны, помогают воссоздать обстановку. Кроме того, диагональная съемка позволяет передать объем и пространство.

Совершенно недостаточно при съемке значительных по размерам мест происшествий пользоваться лишь нормальной по высоте точкой съемки (это такая точка съемки, при которой линия горизонта делит кадр примерно пополам).

Съемка с верхней точки. При ее применении линия горизонта не делит кадр примерно пополам, а значительно поднята или уходит за рамки кадра вверх. В качестве верхней точки можно использовать холм, крышу, дерево, мост, люльку подъемника, кабину подъемного крана и т.д. При съемке с холма, крыши, моста есть возможность использовать приемы круговой и линейной панорамы. Используя объективы с большим фокусным расстоянием, можно получить с той же точки съемки частично-обзорные и обзорно-узловые снимки ${ }^{43}$.

${ }^{43}$ Например, с близлежащего холма фотографируется место происшествия. Используя объектив с фокусным расстоянием 20 или 35 мм, получают ориентирующий и обзорный 
Съемка с нижней точки, при которой линия горизонта находится в нижней части кадра или даже уходит за границы кадра вниз. Применяется для фиксации значительных по высоте объектов (таких, как дома опоры линий электропередач и др.). С нижней точки съемки можно получить целый ряд снимков, стоя на земле и меняя объектив с фокусным расстоянием 20 мм (или 35-37 мм) на объектив с фокусным расстоянием 58 мм, а затем на 130 мм.

Съемка с глубинным масштабом - квадратным или ленточным, которая позволяет зафиксировать на снимке размеры объектов и расстояния между ними. При использовании этого вида съемки необходимо следить за тем, чтобы оптическая ось объектива была параллельна предметной плоскости. При съемке с квадратным масштабом последний размещается так, чтобы его ближняя сторона совпадала с нижним краем кадра. При съемке с ленточным масштабом его начало располагается точно под объективом. Точкой отсчета служит при этом ближайшее видимое на снимке внизу деление ленточного масштаба.

С квадратным или ленточным масштабом целесообразно фотографировать дорожку следов ног, следы беговой дорожки шины колеса (чтобы по снимкам можно было рассчитать расстояние между ними), воронки (если на месте происшествия их несколько), трупы (если требуется точно зафиксировать расстояние, на котором находится труп от объекта или ориентира) и т.д., другими словами, все объекты, удаленность которых друг от друга или от ориентира необходимо зафиксировать.

При осмотре незначительных по размерам локальных участков места происшествия (таких, как комната, гараж, сарай) съемка с квадратным или ленточным масштабом используется довольно редко: расстояния между объектами на таких местах происшествий невелики, чтобы их определить по фотоснимку, достаточно между фотографируемыми объектами положить масштабную линейку или рулетку.

Съемка с удлинительными кольиами, которая позволяет фиксировать объекты, имеющие небольшие размеры (следы оплавления проводников, остатки взрывных устройств, следы подготовки к взрыву и т.д.). Выполняя такую съемку, следует помнить, какой масштаб съемки обеспечивает то или иное кольцо (та или иная комбинация колец) и какой коэффициент увеличения выдержки предполагает выбранный масштаб съемки.

снимки; с объективом 50-58 мм - несколько частично-обзорных снимков; с объективом 130 мм - обзорно-узловые или даже узловые снимки
Поскольку съемка с удлинительными кольцами в ряде случаев невозможна без штатива (прежде всего при масштабах съемки 1:5-1:1), которого может не оказаться, то для получения требуемого масштаба съемки можно воспользоваться обычными лупами с увеличением $2^{\mathrm{x}}$ или $3^{\mathrm{x}}$.

Прием съемки с лупой весьма прост: между объектом съемки и объективом помещается лупа на таком расстоянии от объекта съемки, которое позволяет хорошо рассмотреть объект или его деталь. Объектив должен находиться на таком расстоянии от лупы, которое обеспечивает резкость изображения при фотографировании. Поскольку лупа поглощает часть света, для получения снимка нормальной плотности при использовании объектива с фокусным расстоянием 50-58 мм следует открыть диафрагму на одно деление (независимо от того, какая лупа используется $-2^{\mathrm{x}}$ или $3^{\mathrm{x}}$ ). Напомним, что при переходе на соседнее деление диафрагмы экспозиция изменяется в 2 раза.

Если съемка производится со вспышкой, во избежание блика от поверхности лупы вспышку следует располагать над лупой, но спереди и сбоку от нее (справа или слева); лупу можно экранировать небольшим куском картона, который не позволит попасть лучам света на верхнюю поверхность лупы. При съемке с лупой масштабная линейка располагается в одной плоскости с объектом съемки, причем так, чтобы часть делений была четко видна через лупу - в этом случае масштаб съемки объекта и масштабной линейки будет один и тот же.

Один человек не сможет одновременно держать в руках фотоаппарат, вспышку, лупу и кусок картона, поэтому при использовании данного приема съемки ему необходимы помощники. Ими могут стать понятые, другие участники следственного действия.

При съемке небольших объектов можно воспользоваться и рассеянным светом от вспышки, для чего свет вспышки направляют в потолок, стену и т.д. или на экран, который можно сделать из подручных материалов (фанеры, обструганных досок, листового железа, картона и т.д.). Поскольку при этом часть лучей поглошается экраном, то величину экспозиции следует увеличить. Коэффициент увеличения экспозиции будет зависеть от отражательной способности экрана и расстояния между вспышкой и экраном. Чтобы не ошибиться в выборе экспозиции, кадры следует дублировать, меняя диафрагму44.

${ }^{44}$ См.: Криминалистика: учебник / Под ред. Н. П. Яблокова. М., 2001. С. 121-134; Криминалистика: учебник / Под ред. В. А. Образцова. М., 2001. С. 201-221; Кориунов В.М. Следы на месте происшествия: обнаружение, фиксация и изъятие. М., 2001. С. 34-43; Следы на месте происшествия: обнаружение, фиксация и и
Шурухнов Н.Г. Криминалистика: учебник. М., 2003. С. 56-72. 


\section{3. Работа со следами различного происхождения}

Уважаемый следователь! Вновь вспомним о «дежурной проблеме»: на место происшествия с вами далеко не всегда выезжает специалистпрофессионал (как правило, работник экспертно-криминалистического отдела/управления), который призван взять на себя все задачи, связанные с обнаружением, фиксацией и изъятием следов рук, ног человека, биологических и иных объектов и микроследов. В крупных городах проблема отсутствия специалиста или эксперта при выезде на место происшествия практически решена. На то они и города... Но в сельских, отдаленных районах, маленьких городках следователи регулярно, а то и постоянно вынуждены выезжать без соответствующей поддержки. В результате теряются важнейшие доказательства, тормозиться расследование. Следователи или не обнаруживают следы, допускают их неосторожное уничтожение, либо вынуждены, где такое возможно, целиком изымать объекты, на которых оставлены следы. Как вариант - опечатывают соответствующие помещения впредь до приезда специалиста. Это, конечно, тоже методы. Но вы же знаете, далеко не всегда они эффективны и вообе применимы.

В рамках повышения квалификации следователей постоянно инструктируют и рекомендуют самостоятельно изучать специальные методы работы со следами. Но все же стоит признать, что вряд ли даже самый опытный следователь, дознаватель, а уж тем более общественный помощник обнаружат следы, зафиксируют их, изымут, упакуют отпечатки и иные объекты - будущие вещественные доказательства так, как это сделает специально подготовленный работник, не отвлекающийся в ходе осмотра на другие задачи.

Но проблему надо как-то решать. Мы предлагаем лишь одно, быть может, опять-таки не самое лучшее, но проверенное практикой средство - специально обучать и привлекать к решению этих задач общественных помощников ${ }^{45}$. Как ни в одном другом вопросе, в этом часто молодой следователь и его общественный помощник равны по уровню знаний и навыков. Точнее так - оба примерно одинаково некомпетентны. Но у общественного помощника есть два преимущества: во-первых, у него больше времени на обучение и специальную подготовку; во-вторых, в ходе осмотра он может заниматься только этим вопросом,

${ }_{45}$ Считаем, что, как правило, не следует привлекать к решению этой задачи практиканта. Слишком кратко время его пребывания в следственном органе. Только научишь, а он уже покинул отдел и вернулся на занятия. в то время как следователь руководит следственным действием и решает целый ряд других задач.

Предлагаем следующий алгоритм подготовки общественного помощника к работе со следами:

1. Для начала поручите изучить, перечитать заново учебную и учебнопрактическую литературу по криминалистической технике в целом и, в частности, по следующим ее отраслям: криминалистическая трасология, криминалистическое исследование веществ и материалов, криминалистическая одорология ${ }^{46}$. Если считаете нужным, примите своеобразный зачет.

2. Направьте его к опытному специалисту или эксперту ЭКО (ЭКУ). Попросите последнего провести с вашим помощником ряд консультаций, а также взять его с собой на несколько выездов. Нужно чтобы он под контролем специалиста попробовал хотя бы выявлять и фиксировать, а еще лучше - изымать следы рук, ног, микроследы, запаховые следы и др.

3. Заранее обеспечьте его соответствующими криминалистическими средствами и техникой: порошки, кисточки, скотч, гипс и т.д. Оговорите личную ответственность общественного помощника за их сохранность и постоянную готовность к работе.

4. Покажите общественному помощнику, практиканту типовой результат предстоящей работы - протоколы осмотра предметов - вещественных доказательств, постановления о назначении и заключения трасологических, биологических, одорологических и иных экспертиз, протоколы допросов экспертов, приговоры судов со ссылками на соответствующие доказательства и другие документы по уголовным делам, законченным производством. Обучите составлению соответствующих процессуальных документов. Помошник должен заранее знать все вопросы, связанные с движением вещественных доказательств на всех стадиях уголовного судопроизводства. Тогда он «умом и сердцем» поймет, насколько важны различные детали в фиксации и изъятии соответствующих объектов. Расскажите о личных предпочтениях и пожеланиях.

5. Ознакомьте с содержанием всей этой главы.

Теперь ваш общественный помощник, пожалуй, окончательно готов к выезду на место происшествия. Берите его с собой, только поначалу тщательно контролируйте его работу.

46 Дубягин Ю.П. Руководство по розыску и расследованию неочевидных убийств. М.: Юрист, 1998. С. 101-146; Поль К.Д. Естественно-научная криминалистика. М.: Мир, 1985. C. $234-346$ 
Ниже предложены краткие рекомендации о работе с различными типами следов, которые не всегда описаны в учебной литературе. Подробные рекомендации имеются в специализированных практических изданиях. Но вновь отметим: поскольку они предназначень для экспертов и специалистов, они, чаще всего, бывают сложными для восприятия, слишком подробными. Чаще они охватывают весь процесс экспертного исследования, что ни для следователя, ни для общественного помощника не является актуальным.

\section{4. Обнаружение, фиксация и изъятие следов рук}

Важной задачей осмотра места происшествия является обнаружение следов рук человека. Поэтому осмотр любого объекта (орудие преступления, осколки разбитого стекла, посуда, дверные ручки, замки, разбросанные вещи, валяющаяся бумага и т.д.) следует начинать с отыскания на них следов рук.

Для того чтобы на этих предметах не уничтожить следы и не оставить своих, необходимо, как правило, брать предметы за те их части, на которых практически не образуются следы рук, а именно: за края, ребра, дно, за рельефные, шероховатые, не обработанные гладко поверхности ${ }^{47}$.

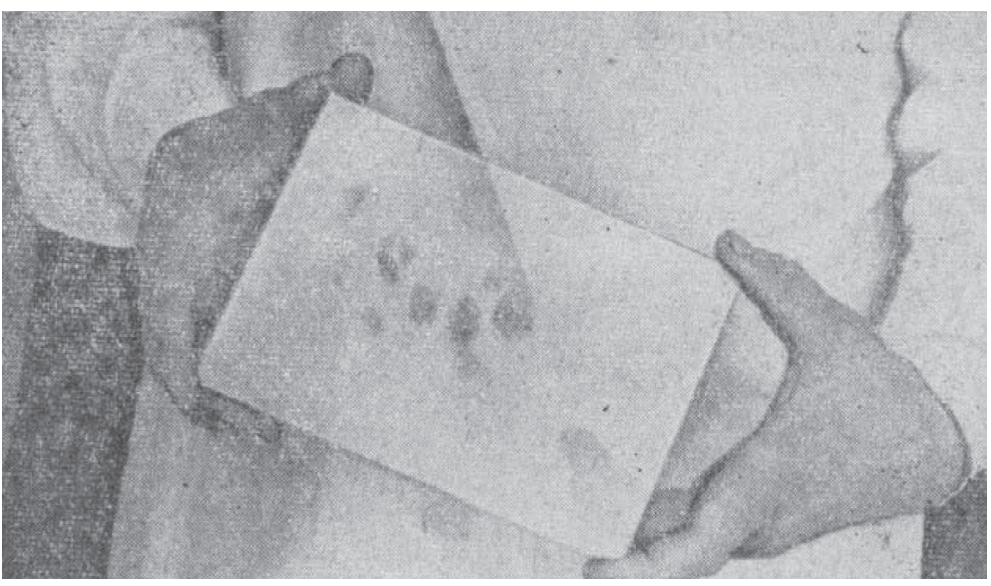

Рис. 1. Так следует брать кусок стекла при отыскании следов рук

${ }^{47}$ См.: Курс криминалистики / Под ред. О. Н. Коршуновой, А. А. Степанова. - СПб., 2004. - T. I. - C. $134-145$
Так, осколки оконного стекла рекомендуется брать только за ребра, и если следы рук видны, то держать стекло вверх той стороной, на которой следы (рис. 1). Также следует обращаться с кусками фанеры, зеркалами, рамками, с фотографиями и другими плоскими предметами.

Стаканы надо брать, положив ладонь или пальцы на верхний край и подведя пальцы под дно (рис. 2). Таким же образом берут чашки, стеклянные банки и другие аналогичные изделия из стекла или из пластмассы.

Бутылку следует брать одной рукой, нажимая сверху на горлышко или введя в него палочку, карандаш, палец, а другой придерживая за дно (рис. 3). Подобным образом берут графины, различные флаконы, пробирки и другие аналогичные предметы.

Коробки из дерева, картона, пластмассы и металла, шкатулки и т.п. можно брать за углы обеими руками (рис. 4). Ножи берут одной рукой за тыльную часть рукоятки, а другой - за кончик клинка (рис. 5). Также берут вилки, чайные и столовые ложки и другие подобные предметы.

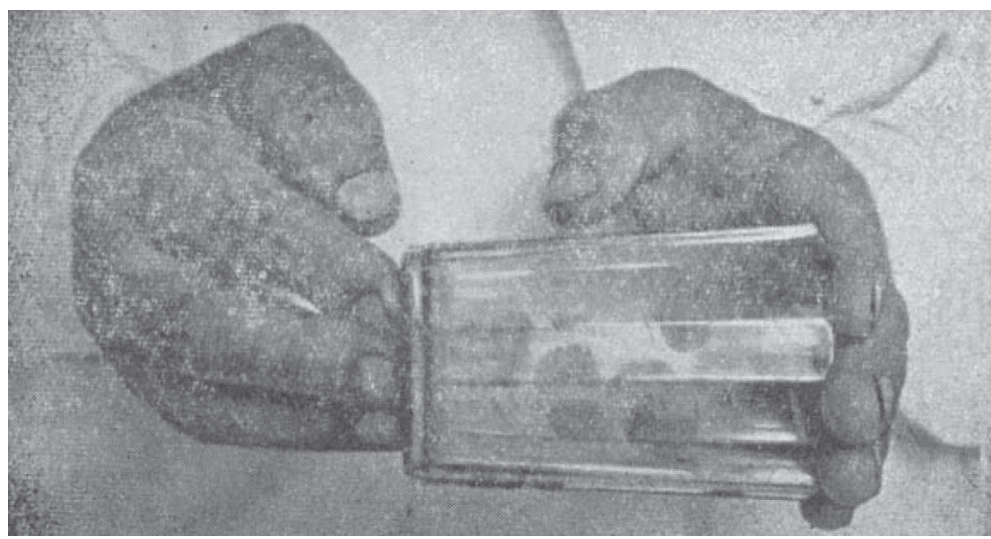

Рис. 2. Так берут стакан при отыскании следов рук

Пистолеты и револьверы надо брать за дульный срез ствола и рифленные щечки рукоятки или за другие детали, на которых не могут остаться пригодные для отождествления следы рук (рис. 6).

Бумагу берут пинцетом или руками в перчатках (рис. 7), электрическую лампочку - за ту часть, которая ближе к металлическому цоколю, если там нет следов рук.

На крупных предметах (шкаф, дверь, радиоприемник и т.д.) ищут следы, рассматривая поверхности предмета с разных сторон, под разным углом зрения. 


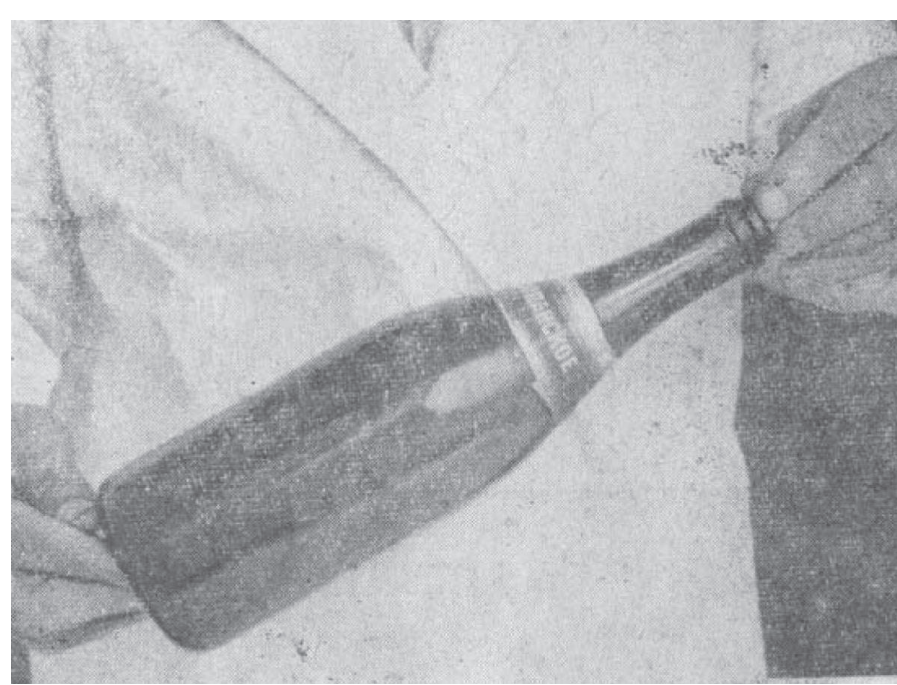

Рис. 3. Так берут бутылку при отыскании следов рук

Обнаруженные при осмотре следы рук должны тщательно оберегаться, после соответствующей фиксации места их нахождения мелкие предметы со следами складывают туда, где осмотр уже произведен и желательно, чтобы к ним никто не подходил. В ряде случаев полезно там, где обнаружены следы рук или же складываются предметы со следами, поручить помощнику прикрепить лист бумаги с надписью: «Предметы не трогать, на них следы рук!»

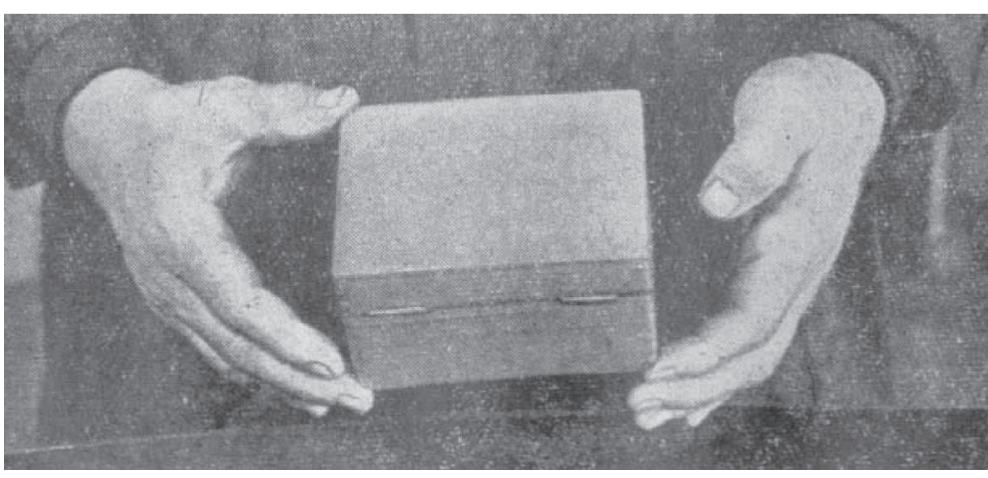

Рис. 4. Так следует брать коробки, шкатулки при отыскании следов рук

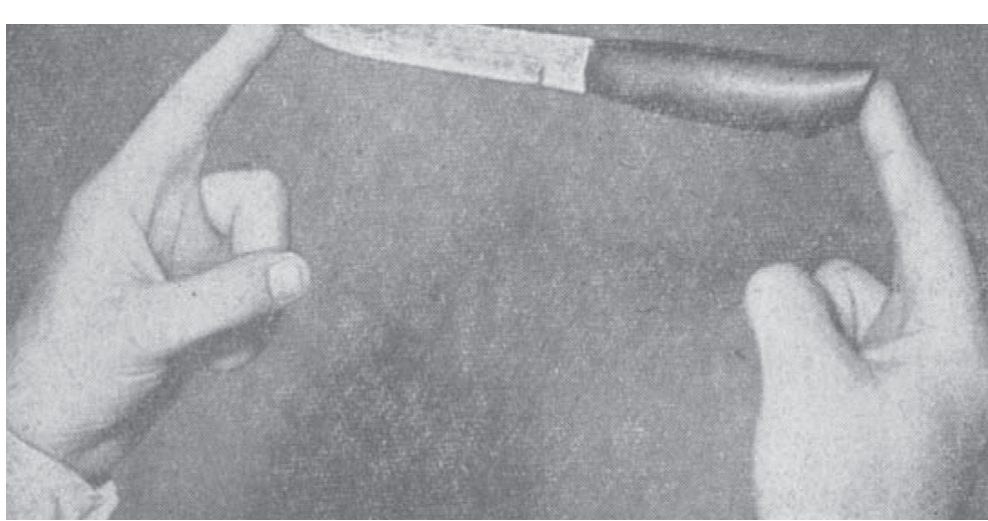

Рис. 5. Так берут нож при отыскании следов пальцев рук

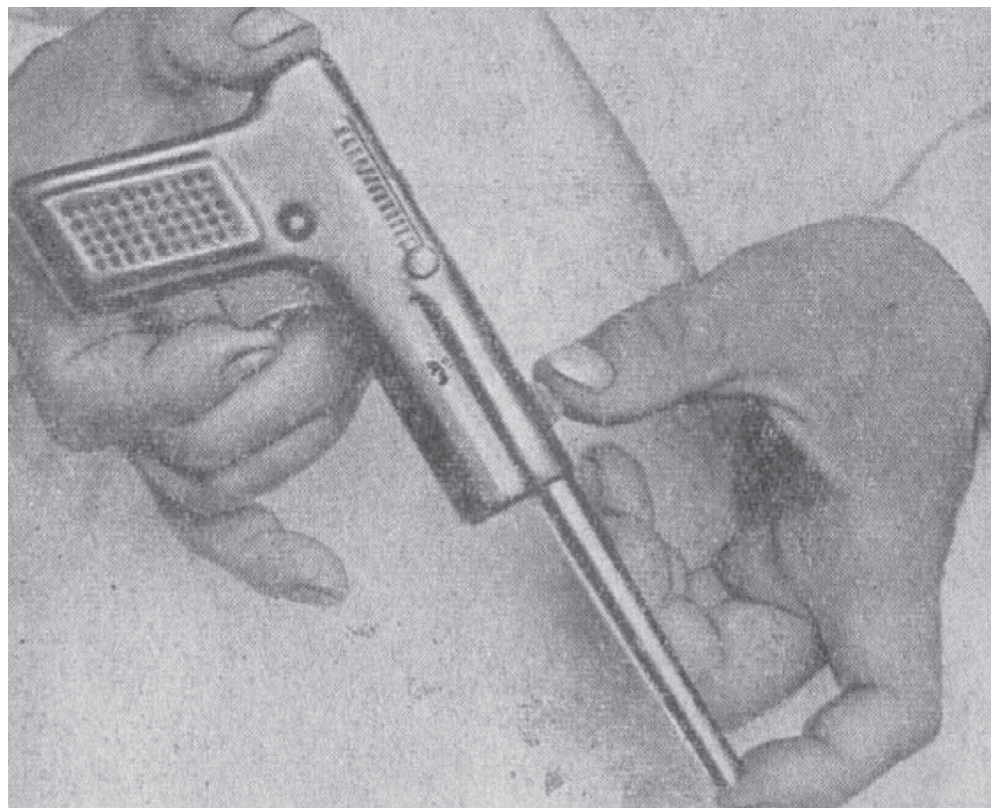

Рис. 6. Так берут пистолеты и револьверы

В тех случаях, когда следы рук найдены вне помещения и могут подвергнуться воздействию дождя, снега или яркого солнечного света, предметы со следами лучше сразу же после фотографирования пере- 
нести в помещение или следы зафиксировать и изъять одним из способов, описание которых будет дано дальше.

Обнаружить следы рук на месте происшествия во многих случаях трудно по двум причинам.

Во-первых, как уже указывалось, эти следы обычно малозаметны или же вовсе невидимы до технической обработки поверхности предмета, на которой они оставлены.

Во-вторых, преступники нередко принимают специальные меры, чтобы не оставить на предметах, которых они касаются руками, своих следов. Иногда они совершают преступления в перчатках, вытирают тряпкой, носовым платком предметы, которые брали руками, или, наконец, уносят эти предметы с места преступления и где-нибудь выбрасывают.

Поэтому искать следы рук необходимо очень тщательно на всех предметах, которых мог коснуться субъект.

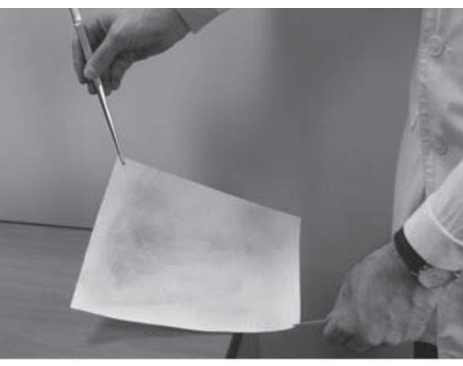

Рис. 7. Так берут бумагу при отыскании следов пальцев рук

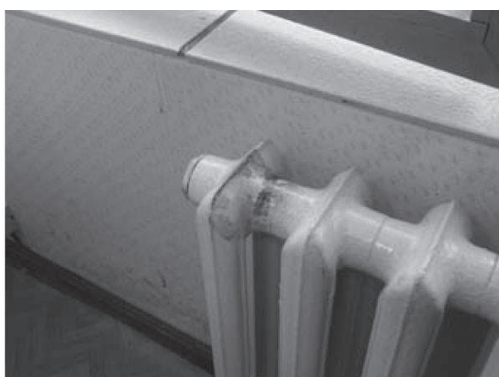

Рис. 8. Следы рук, обнаруженные на радиаторе отопления (следы окрашены порошком окиси меди)
Прежде чем приступить к розыску следов рук, следует изучить обстановку на месте, выяснить, какие действия производил преступник (как проник в помещение, где ходил, что делал на месте происшествия, какие предметы перемещал, каким путем ушел и т.д.).

Если, например, преступник проник в помещение, взломав дверь, то тщательно осматриваются ее поверхность, ручка, замок, косяки и т.д. В случае, если он проник в помещение через окно, необходимо собрать и внимательно осмотреть все осколки разбитого или выдавленного стекла. Следы рук нужно также искать на подоконнике, трубах и радиаторах отопления (рис. 8), под окном на предметах, находившихся на подоконнике и сброшенных с него.
Если преступление было совершено в ночное время, осматриваются выключатели, абажуры настольных ламп, а также сами лампочки.

Зная, каким образом преступник проник в помещение, и место, откуда похищены вещи или ценности, устанавливают наиболее вероятный путь движения преступника в комнате и осматривают предметы, которые мешали его передвижению, - спинки стульев, края столов, тумбочки, стенки шкафов, верхние части кроватей.

Обязательно следует осматривать предметы, обычное положение которых нарушено, например, опрокинутую мебель, вещи, выброшенные преступником из шкафов, чемоданов и т.д.

Осмотру подлежат также внутренние хранилища, которые были вскрыты преступником. Особое внимание при этом обращается на ручки, замки шкафов и столов.

Отыскивая следы рук, особенно тщательно надо осмотреть бутылки, графины, стаканы, рюмки, тарелки и другую посуду, если предполагается, что преступник ел или пил на месте происшествия.

При обнаружении угнанных автомашин следы рук нужно искать на ручках и стеклах дверец, ветровом стекле, колесе рулевого управления, передней панели автомашины, зеркале обратного вида, противосолнечных щитках, а также на хромированных частях автомашины (колпаках колес, бамперах и т.д.). В случаях, когда с машины сняты колеса, похищен аккумулятор или инструмент из багажника, необходимо искать следы рук на крыльях, капоте и дверце багажника ${ }^{48}$.

Наконец, с особым вниманием надо осмотреть все те предметы, которые преступник, принеся с собой, оставил или обронил. Ими могут быть: электрический фонарь, свечи, орудия взлома и бумага, в которую они могли быть завернуты, холодное и огнестрельное оружие, магазины к нему, различные мелкие предметы в карманах одежды преступника, если он бросил ее на месте происшествия, переодевшись в похищенное (расческа, очки, пачка с сигаретами, автоматическая ручка и пр.). Все эти предметы могут нести на себе следы рук преступника.

Таким образом, при обнаружении следов рук на месте преступления всегда приходится осматривать большое количество самых различных объектов. Часто следователю очень сложно сделать это в одиночку. Это еще один довод в пользу использования труда общественного помощника.

При осмотре мест совершения разбойных нападений, изнасилований, убийств и других преступлений на открытой местности следы рук

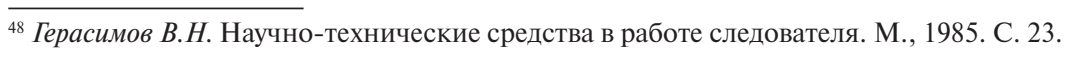


также могут быть обнаружены на орудиях преступления и на предметах, оброненных или брошенных преступником.

Обнаружение следов рук окрашенных, вдавленных и на пыльной поверхности не представляет особых трудностей у следователя, его помощника. Все зависит от их внимательности. Значительно труднее найти бесцветные потожировые следы.

На прозрачных и глянцевых поверхностях бесцветные следы можно обнаружить визуально, на неглянцевых и непрозрачных поверхностях - применяя специальные приемы «проявления», окрашивания следов.

На прозрачных предметах (кусок стекла, бутылка, стакан и т.п.) бесцветные следы видны на просвет при определенном, в каждом случае несколько различном, положении поверхности предмета относительно источника света и наблюдателя. Поэтому рекомендуется менять положение поверхности предмета, на которой ищем следы, относительно источника света (окна, горящей электролампочки и т.д.). Если вся поверхность предмета блестит под светом, а следов не видно, по-видимому, их нет

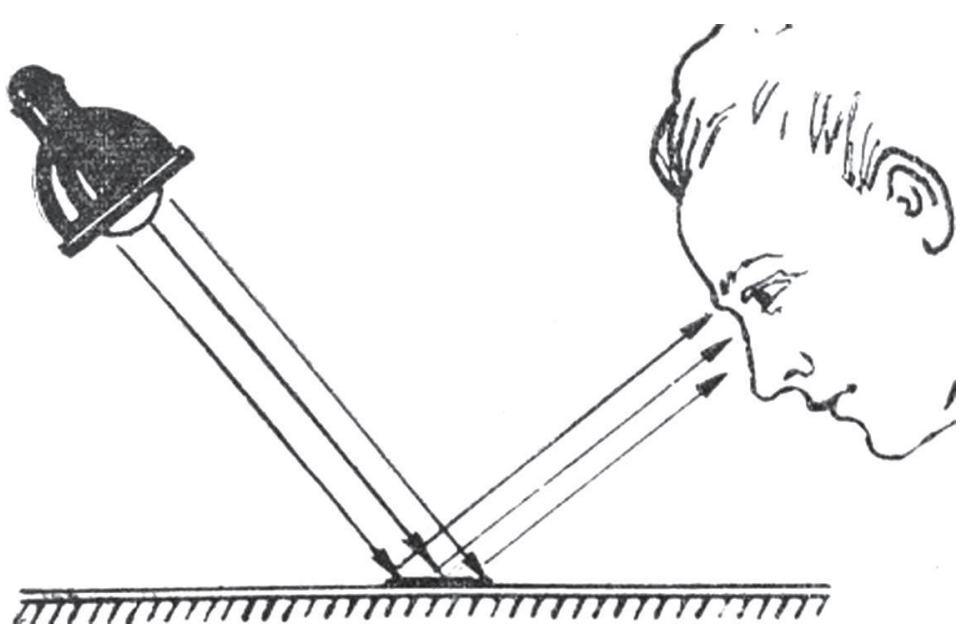

Рис. 9. Обнаружение следов рук в отраженном свете

При отыскании потожировых следов на непрозрачных глянцевых поверхностях нужно помнить о различной отражающей способности участков поверхности, покрытых потожировым веществом, и участков, где этого вещества нет. Лучше всего следы видны при боковом освещении поверхности предмета. Места, покрытые потожировым вещес- твом, отражают лучи света рассеянно, а участки, свободные от этого вещества, - направленно (рис. 9) ${ }^{49}$

Различие в отражающей способности потожирового вещества и поверхности воспринимающего объекта используется также для обнаружения следов на прозрачных предметах.

Контраст между следом и поверхностью может быть усилен путем осмотра объектов в затемненном помещении с помощью источника направленного света (электрическая настольная лампа или карманный электрофонарь).

Если при первичном осмотре обнаружить следы на предметах, например, на бумаге, картоне и т.п. не удается, но есть основания предполагать, что преступник к ним прикасался, их необходимо отложить в сторону, чтобы затем выявить следы с помощью специалистов, применяющих порошки, пары йода или другие средства. В этом случае предметы следует изымать, либо при отсутствии такой возможности опечатывать помещение, организовывать охрану территории впредь до вызова специалиста.

Приведенные рекомендации, конечно, не являются исчерпывающими и однозначными. В каждом конкретном случае только сам следователь, исходя из конкретной следственной ситуации, определяет на каких объектах преступник мог оставить следы рук, стоит ли ему или его помощнику изымать их самостоятельно или нужно вызывать временно отсутствующего специалиста. Окончательное решение по каждому из этих вопросов должен принимать следователь. Самодеятельность общественного помощника в этих вопросах совершенно неуместна.

\section{5. Обнаружение, фиксация и изъятие следов ног}

В целях обнаружения следов ног на месте происшествия рекомендуется осмотреть:

- поверхность земли, пола, валяющиеся на земле (или полу) предметы;

- предметы обстановки, которыми мог пользоваться преступник (столы, стулья, табуреты, скамейки и др.);

- предметы и поверхности на пути следования преступника (чердак, крыша, лестничный марш и т.д. $)^{50}$.

Так как в большинстве случаев следы ног хорошо видимы, особых приемов для их обнаружения не требуется. Трудности возникают при

${ }^{49}$ Исаенко В.Н., Козлов М.П., Константинов В.Р. Средства работы с вешественными доказательствами // Законность. 1995. № 5. С. 54-57.

${ }^{50}$ Герасимов И.Ф., Драпкин Л.Я. Криминалистика: учебник. М., 2000. С. 124-129. 
поисках следов стопы, образованных выделениями пота. Такие следы надо отыскивать с помощью освещения, направленного к поверхности следа под различными углами (косопадающего освещения).

Обнаружив следы, необходимо принять меры к их сохранению до момента изъятия и фиксации. В целях предохранения их от порчи, следы ног прикрывают листами бумаги, картона, фанеры или какимилибо предметами (ящиками, ведрами и др.).

Перед изъятием найденные следы ног фотографируют методом узловой измерительной фотосъемки, соблюдая следующие правила:

1. Задняя стенка фотоаппарата должна быть расположена параллельно плоскости следа, а оптическая ось объектива направлена в центр следа. В данном случае лучше использовать штатив со штативной головкой.

2. Освещение должно обеспечивать четкую видимость рельефа следа, что достигается применением косопадающего света. В зависимости от направленности линий, имеющихся в следе, освещение направляется вдоль или поперек следа. Съемку необходимо продублировать. Объемные следы на снегу следует фотографировать с желтым или оранжевым светофильтром, если съемка производится на черно-белую пленку или цифровой фотоаппарат.

3. Масштабная линейка располагается в одной плоскости со следами ${ }^{51}$.

Фотографирование дорожки следов производится либо способом линейной панорамы (съемка по частям), либо с глубинным масштабом в виде мерной ленты. Предпочтительнее использовать первый способ фиксации ${ }^{52}$

Кроме фотографического, применяют следующие способы фиксации следов ног:

- изготовление слепков;

- перенос на следокопировальную пленку;

- составление схематических чертежей;

- зарисовка.

Следует иметь в виду, что схематический чертеж и рисунок непригодны для идентификации оставившего след человека или обуви. Посредством чертежей и рисунков фиксируют только общее строение единичных следов и элементы дорожки следов.

Назначение схематического чертежа единичного следа - дать представление о составных частях следа и его размерах. Все необходимые

${ }_{51}$ См.: Селиванов Н.А., Снетков В.А. Руководство для следователей. М., 1997. С. 301-304. 52 Подробнее об этом см.: Яковлев Д.Ю. Специальные виды фотосъемки. Иркутск, 1998. $34 \mathrm{c}$ размеры обозначаются цифрами. Схематический чертеж дорожки следов должен содержать данные о длине, ширине и угле шага. Схематический чертеж единичного объемного следа вычерчивается до изготовления слепка, а плоскостного - до переноса его на следокопировальную пленку.

Изготовление слепков. Этот процесс не сложен и не трудоемок, к тому же в юридических вузах обучают этому. А потому рекомендуем следователям и их помощникам при необходимости самостоятельно изготовлять гипсовые слепки следов ног. Гипс необходимо хранить в сухом месте в плотно закрытой таре. Однако нужно помнить, что при длительном хранении гипс часто теряет способность затвердевать. Так что время от времени поручайте помощнику проверять свойства долго хранимого гипса.

При формировании гипсового слепка наблюдаются две стадии, а именно: стадия текучести, при которой слепочная масса сохраняет текучесть и подвижность, и стадия схватывания, характеризующаяся потерей подвижности и постепенным (в течение 5-15 минут) затвердеванием массы. Схватывание гипса сопровождается выделением тепла и нагреванием массы до $20{ }^{\circ} \mathrm{C}$ и некоторым равномерным увеличением объема (примерно до $1 \%)^{53}$.

Последнее обстоятельство обусловливает более точную передачу рельефа следов, так как при увеличении объема и благодаря своей тяжести слепочная масса заполняет все мельчайшие углубления в следе.

Время затвердевания гипса можно регулировать посредством добавления замедлителей и ускорителей.

Потребность в замедлении схватывания гипса может появиться при работе с некоторыми его видами, как, например, зуботехническим гипсом, который, будучи смешан с водой, образует твердую массу уже через 2-3 минуты. Поэтому, чтобы иметь достаточно времени для укладывания каркаса и заливания гипса, применяются замедлители. В качестве них могут быть использованы 7-8-процентный раствор поваренной соли (хлористого натрия) или насыщенный раствор буры. Последний получают посредством добавления отдельных порций буры к воде, нагретой до $23{ }^{\circ} \mathrm{C}$, до тех пор, пока бура перестанет в ней растворяться. Насыщенный раствор буры добавляется в воду, предназначенную для смешения с гипсом в количестве одной чайной ложки этого раствора на стакан воды.

${ }_{53}^{5}$ Руководство для следователей / Под ред. Н.А. Селиванова, В.А. Снеткова. М.: Высшая школа, 1998. 436 с 
Для ускорения затвердевания слепочной массы, например, при изготовлении гипсового слепка со следа на снегу или на пищевых продуктах в воду может быть добавлен или нашатырь (хлористый аммоний), или сернокислый натрий, или сернокислый калий - в количестве одной чайной ложки на стакан воды. Для этих же целей (исключая случаи изготовления слепков со следа на снегу) может быть использован 4-процентный раствор поваренной соли.

Гипсовый слепок устойчив при нагревании до $50{ }^{\circ} \mathrm{C}$, что исключает возможность его деформации. При долгом нахождении в воде слепок деформируется незначительно, однако прочность его сильно снижается. К недостаткам гипсовых слепков следует отнести их относительную хрупкость.

Для изготовления гипсовых слепков с объемных следов целесообразнее использовать модельный (скульптурный) гипс и медицинский (зуботехнический). Штукатурный гипс (алебастр) дает менее точные копии следа.

Гипс должен быть пудрообразным, без комков, мягким на ощупь и сухим. Гипс, содержащий комки, необходимо просеять через сито или марлю. Влажный гипс не пригоден для изготовления слепков.

Пригодность гипса для работы со следами можно проверить так. Нужно смешать одну столовую ложку воды и полторы столовых ложки гипса. Затвердевшая через 15 минут масса не должна терять своей формы и крошиться. Надломленный кусочек затвердевшей массы не должен разминаться между пальцами, а лишь только разламываться. Если кусочек затвердевшей массы разминается с выделением влаги, то гипс для изготовления слепков не пригоден.

Изготовление гипсовых слепков со следов, оставленных на прочном грунте. Перед изготовлением гипсового слепка поверхность найденного следа очищается от воды и посторонних предметов, попавших на след после его образования. Вдавленные в след предметы (камешки, листья и пр.) извлекать не рекомендуется, так как при этом след может разрушиться. Вода из следа удаляется с помощью промокательной, фильтровальной бумаги, мягкой ткани, ваты.

Если след неглубокий, вокруг него делается валик из грунта, деревянный или картонный бортик, для того чтобы слепочная масса не растекалась. Во избежание разрушения следа грунт для валика рекомендуется набирать подальше от следа.

Для укрепления слепка заготавливается каркас из нескольких не превышающих размеры следа лучинок (палочек, прутиков или проволочек), к одной из них привязывается кусок шпагата длиною 10-15 см с деревянной или картонной биркой.
Каркас из древесины, впитывая воду, может разбухать и вызывать появление трещин в слепке. Поэтому предназначенную для каркаса древесину следует предварительно смочить водой.

На бирке делается надпись, с какого следа сделан слепок, где и когда. Бирки подписывают следователь и понятые, присутствовавшие при изъятии следа.

После этого готовится слепочная масса. В миску или другую посуду наливается вода, в которую постепенно, при постоянном перемешивании, всыпается гипс. На 1 часть воды берется приблизительно 1,5 части гипса.

Указанные пропорции являются примерными. Соотношение количества гипса и воды зависит от вида и состояния гипса. Как жидкая, так и слишком густая слепочная масса уплотняется хуже, в результате чего в слепке образуются пустоты. Поэтому при добавлении гипса необходимо тщательно следить за тем, чтобы полученная слепочная масса обладала подвижностью, «текучестью», то есть свободно стекала с ложки и при выливании пробы на грунт не образовывала сгустков и комков.

Заливается в след первый слой гипса приблизительно до половины его глубины. Чтобы масса гипса не разрушила след при заливке первого слоя, гипс льют не в сам след, а на прилегающую к нему поверхность так, чтобы масса стекала в него с этой поверхности, или же с помощью желобка из картона или из бумаги, опуская конец желобка как можно ближе к поверхности следа. На этот слой помещается каркас.

Затем, когда первый слой массы слегка затвердеет, выливается остальная слепочная масса - второй слой.

По затвердевании массы слепок извлекается из грунта и в случае налипания на него земли, песка, и др. осторожно моется водой путем неоднократного опускания в какую-либо посуду с водой или же путем обливания. Нельзя счищать со слепка грунт какими-либо предметами, проводить по слепку рукой, пользоваться при смывании тряпкой и пр.

Изготовление слепков со следов на снегу и сыпучих грунтах. Для этого вокруг следа возводится валик из снега или картона, и след опыляется с помощью мелкого сита сухим гипсовым порошком до образования слоя толщиною приблизительно 3 мм. В мокром снегу опыление производится до момента, когда насыпанный гипс перестанет увлажняться. Сверху слоя сухого гипса наливается первый слой жидкой гипсовой массы. Затем укладывается каркас и выливается остальная гипсовая масса, образующая второй слой.

Для получения слепка со следа в снегу, воду, предназначенную для смешения с гипсом, надо как можно больше охладить. Если для охлаждения используется снег или кусочки льда, то они добавляются в воду 
до тех пор, пока не перестанут в ней таять. Нерастворившиеся кусочки снега или льда надо из воды удалить до всыпания в нее гипса.

Гипсовая масса должна быть немного гуще, чем предназначенная для слепка со следа в грунте, так как излишняя вода, не связавшаяся с гипсом, при низкой температуре замерзнет и вследствие этого качество готового слепка снизится. Слепочная масса пригодна для изготовления слепка со следа в снегу, если вылитая недалеко от следа проба не останется на поверхности снега и не впитается в него.

Кроме гипса, для получения слепков со следа в снегу может быть использована сера. Для этого последняя расплавляется в металлической миске на огне и двукратно заливается в след.

После затвердевания серы готовый слепок извлекается из следа.

В непрочном сыпучем грунте (сухом песке, пыли, муке и т.п.) гипсовый слепок можно изготовить двумя способами: путем предварительного опыления сухим гипсом, как это делается при изготовлении слепков в снегу, и путем предварительного закрепления следа

Сухой гипс просеивается через сито на след до образования слоя приблизительно в 3 мм. После этого действуют как обычно, то есть заливают в след жидкий гипс в два приема с прокладкой между слоями каркаса. По второму способу след предварительно обрабатывают специальными растворами-закрепителями, после чего обычным способом заливают жидкий гипс также в два слоя с каркасом. В качестве закрепителей могут быть использованы по выбору: 20-процентный раствор сахара (2 столовые ложки сахарного песка на стакан воды); 6-процентный раствор шеллака в спирте (на 94 мл спирта 6 г измельченного шеллака). Для закрепления следа обуви (ноги) среднего размера требуется около 75-80 мл раствора шеллака или 2,5-процентный раствор целлулоида в ацетоне (98 мл ацетона и 2,5 г мелко нарезанной кинопленки, предварительно очищенной горячей водой от эмульсионного слоя, пленка растворяется в ацетоне в течение 4-5 минут). Можно также использовать и спиртовой раствор столярного лака.

Указанные растворы наносятся на след тонким слоем с помощью пульверизатора. Во избежание разрушения деталей следа сильной струей воздуха, выходящей из пульверизатора, последний держат от следа на некотором расстоянии (не ближе $60 \mathrm{~cm}$ ) так, чтобы выходящие из пульверизатора частицы раствора падали на след силой собственной тяжести (наподобие дождя).

Для того чтобы выяснить, какой из этих способов целесообразнее в данных условиях, рекомендуется сделать пробные следы на том же грунте и изготовить с них слепки обоими способами, после чего сравнить полученные слепки и выбрать лучший для данного случая способ.
Однако не следует забывать, что основным средством фиксации обнаруженных следов ног является их описание в протоколе следственного действия. В протоколе описываются отдельные следы и дорожка следов, если она имеется.

Следователь может поручить своему общественному помощнику подготовить в черновике этот фрагмент описательной части протокола, а затем, проверив текст, перенести его в сам протокол.

При описании отдельных следов должны быть указаны:

1) месторасположение следа;

2) вид следа - объемный, поверхностный;

3) чем оставлен след - босая нога, обувь;

4) является ли след полным или частичным;

5) вид грунта (песок, глина и т.д.), вид поверхности (пол, ковер и т.п.), характеристика красящего вещества, если следы поверхностные (жидкость, твердые частицы, цвет вещества и т.д.);

6) общее строение подошвы обуви (есть ли подметка, каблук, является ли подошва гладкой или рельефной, признаки, по которым можно судить о способе крепления подошвы, особенности рельефа в виде потертостей, заплат, их форма, размеры и расположение);

7) форма подошвы обуви (форма носка, заднего среза подметки, переднего среза каблука и т.д.);

8) размеры следа и его частей (длина общая, длина и ширина подметки, промежуточной части, длина, ширина и высота каблука);

9) каким способом зафиксирован след;

10) как изъят и упакован предмет со следом или слепок, следокопировальная пленка.

При описании дорожки следов в протоколе указываются:

1) линия направления движения;

2) длина шага;

3) ширина шага;

4) угол шага.

Приводим образец фрагмента описательной части протокола следственного действия:

«...около дома № 83 по ул. Партизанская в 3 м 15 см от восточного угла дома и 6 м 5 см от трансформаторной будки на взрыхленной земле обнаружена дорожка следов обутых ног. Следы отпечатками носков обращены в сторону остановки общественного транспорта «Завод Эталон». Следы наблюдаются на протяжении 8 м. В результате измерения элементов дорожки следов получены следующие данные: 
1) длина шага левой ноги - 70-74 см;

2) длина шага правой ноги - 78-80 см;

3) ширина шага - 18 см;

4) угол шага левой ноги - положительный, 18-19 ;

5) угол шага правой ноги - положительный, 22-24․

Среди следов обнаружен один четкий след, образованный обувью для правой ноги. Данный след имеет отпечаток подметки, каблука и промежуточной части.

Общая длина следа - 30 см, ширина отпечатка подметки в наиболее широком месте - 11 см, длина отпечатка подметки - 16 см, ширина отпечатка промежуточной части в наиболее узком месте - 5,5 см, длина отпечатка каблука -8 см, его ширина $-6,5$ см. Глубина следа в области носка -3 см, в области каблука -5 см, в области промежуточной части -2 см. Форма подметки характеризуется острым носком, прямым задним краем. Внутренний край промежуточной части имеет значительную кривизну. Передний край каблука вогнутый. Вдоль границ следа подметки имеется линейное возвышение шириной приблизительно 1,5 мм, размещенное в 1-1,3 см от границы следа. В следе подметки имеется возвышение, состояшее из двух частей, образующих между собой угол примерно $120^{\circ}$. Угол вершиной обрашен к внутреннему краю подметки. Вершина угла находится на расстоянии 2,5 см от границы следа. Ширина возвышения равна приблизительно 0,4 cм, длина одной части возвышения (обрашенной к заднему краю подметки) - 1,2 см, длина другой его части $-0,8$ см. Данный след был сфотографирован по способу узловой масштабной съемки. Затем был изготовлен гипсовый слепок следа. Слепок следа был завернут в лист белой бумаги и упакован в фанерный ящик с ватой. Ящик перевязан шпагатом и опечатан при помощи сургуча печатью, имеющей текст: «Следователь СУ при УВД Иркутской области В.В. Грамотеев» ${ }^{54}$.

\section{6. Особенности фиксации и изъятия объектов биологического происхождения}

В случае обнаружения на месте происшествия объектов биологического происхождения (следы крови, тканей организма человека, волосы, слюна и др.) целесообразно придерживаться следующих правил

\footnotetext{
${ }_{54}$ Леви А.А. Осмотр места происшествия: справочник следователя. М., 1982. С. 124.
}

работы ${ }^{55}$. Сразу же после обнаружения объекты и места их обнаружения фиксируются с помощью фотосъемки и (или) видеозаписи.

Затем производится общий осмотр, выявление и описание видимых общих и частных признаков объекта и окружающей его обстановки. Во внимание принимается форма, размеры, состояние объекта, его цвет, следы и особые приметы, а также состояние, положение и вид сопутствующих вещей (предметов), находящихся поблизости. Фиксируется расстояние между сопутствующими вещами и объектами поиска и исследования.

Далее объект извлекается (поднимается), переворачивается, отодвигается в сторону. Обследуется его ложе и все, что находится на нем, а также не воспринятые при общем исследовании скрытые до этого части, стороны объекта. Так, например, по делам о пожарах, повлекших гибель людей, исследуются части (фрагменты) одежды, находившиеся под трупом и не подвергшиеся действию огня. Фиксация в протоколе при этом сопровождается фото-, иногда видеосъемкой ${ }^{56}$.

Особое внимание следует уделять фиксации и изъятию следов крови. На них необходимо остановиться подробнее, поскольку они являются наиболее значимыми при расследовании таких особо тяжких преступлений, как убийство, квалифицированные виды изнасилования, разбой и т.п. В самом общем виде правила таковы:

1) небольшие предметы (части одежды, предметы хозяйственно-бытового назначения и т.п.) со следами крови необходимо изымать целиком;

2) одежду и материю со следами крови также следует изымать целиком. Причем в целях сохранения следов крови в необходимых случаях поручите общественному помощнику нашить на соответствующее место чистую белую материю или неокрашенную бумагу. Влажную одежду лучше предварительно просушить при комнатной температуре без доступа прямых солнечных лучей;

3) там, где это целесообразно, можно выпилить часть предмета со следом крови;

4) если предмет нельзя изъять целиком или отделить его часть со следами, то следует соскоблить следы крови или иного вешества био-

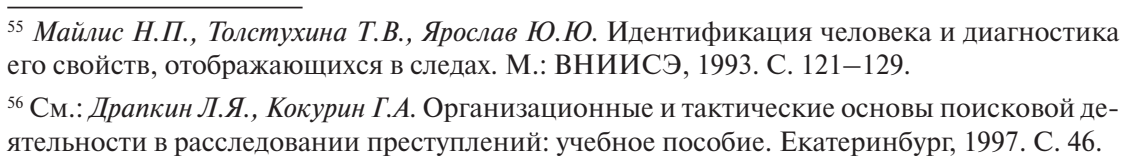


логического происхождения ${ }^{57}$ на чистую неокрашенную бумагу либо поместить его в пробирку. Делать это нужно в медицинских перчатках при помощи скальпеля;

5) в случае, когда сделать соскоб не представляется возможным, рекомендуется перенести вещество следа на чистую влажную марлю, прикладывая последнюю к пятну; марлю перед изъятием лучше подсушить;

6) если кровь обнаружена на снегу, то необходимо поместить снег на сухую чистую марлю, а после того как снег растает, марлю следует просушить при комнатной температуре и изъять;

7) если имеется обильный потек или лужа крови, ее надо собрать на сухую чистую марлю, которую также следует просушить при комнатной температуре.

Не лишним будет напомнить, что часто без специальных средств, участия опытного эксперта, важные для следствия, но невидимые или же маловидимые следы крови и иных веществ обнаружить невозможно. А их на месте происшествия может быть немало. Экспертная практика знает немало способов выявления таких следов (на дереве, бумаге, картоне, кирпиче и т.д.), например, при помощи люминола ${ }^{58}$. Если есть основания предполагать наличие на месте происшествия таких следов, лучше все же вызвать эксперта.

Фотографирование следов крови и иных биологических следов на месте происшествия выполняют по общим правилам: обзорная съемка общего вида места обнаружения следов, узловая съемка отдельных предметов со следами и детальная съемка отдельных следов и их групп. В тех случаях, когда фотографирование не может быть проведено или может дать неудовлетворительные результаты, прибегают к изготовлению схематических рисунков (зарисовка или копирование следов). Тщательное фотографирование следов крови на месте происшествия нередко позволяет восстановить механизм их образования даже по фотографиям, в особенности цветным.

Биологический объект упаковывается в бумажный пакет и маркируется. Такие бумажные пакеты (крафт-пакеты) должны быть заготовлены заранее и в необходимом количестве. Маркировать необходимо не только упаковку объекта, но и сам объект. Причем маркировка должна произво-

57 Часто следователь сомневается, обнаружены ли им следы именно крови. Тогда в протоколе, на бирках учиняются надписи типа: «пятна бурового цвета, похожие на кровь».

${ }^{58}$ Савушкин А.В., Коровянский О.Г., Лозинский Т.Ф. Медико-криминалистическое обеспечение получения идентификационной и розыскной информации при установлении личности погибшего по неопознанному трупу. М.: ЭКЦ МВД России, 1997. 42 с. диться таким образом, чтобы фрагменты одного объекта упаковывались в один пакет или же получили один номер (идентификационную серию)

Маркировочная надпись (этикетка) должна содержать сведения о конкретном месте и времени (с точностью до минут) обнаружения объекта; об основных внешних признаках (цвет, форма, состояние, наличие запаха и т.д.). Кроме того, должны отражаться сведения о лице, обнаружившем данный объект, понятых. Все операции фиксируются в протоколе осмотра места происшествия.

Упаковка должна быть достаточно плотной, предохранять объект от загрязнения и механических повреждений, но в то же время обеспечивать вентиляцию содержимого. В противном случае объект может потерять большую часть идентификационных и диагностических признаков из-за развития процессов гниения и разложения. Обращаться с упаковкой следует с особой аккуратностью.

После этого будущие вещественные доказательства упаковывают так, чтобы они не могли быть утеряны или деформированы при транспортировке и на них не попали посторонние вещества. Каждый пакет в отдельности обертывается чистой бумагой, на которой указывают, что в нем содержится, перевязывают бечевкой и опечатывают печатью так, чтобы бечевку нельзя было снять без повреждений оттиска печати. Пакеты с соскобами вешеств, похожих на кровь, и с волосами прошивают по краям ниткой, концы которой скрепляют чернильной печатью с биркой. Затем все свертки и пакеты помешают в деревянный или фанерный ящик. Свободное пространство в нем заполняют бумагой или ватой.

\section{7. Работа со запаховыми следами (одорологические следы)}

Следует отметить, что на сегодняшний день наработана обширная следственная и судебная практика обнаружения, фиксации и изъятия запаховых следов человека, а также практика назначения и производства одорологических исследований. По нашему мнению, у одорологических методов исследования большое будущее, однако следователи, в силу прежде всего трудоемкости описываемых методов, уделяют недостаточное внимание данному виду следов. Нижеприведенные рекомендации позволят интенсифицировать процесс осмотра места происшествия за счет включение в осмотр некоторых одорологических методов.

Как и работа с другими объектами, работа с одорологическими следами на месте происшествия включает их обнаружение, фиксацию, изъятие и непосредственное использование для организации розыска 
людей и предметов по горячим следам. Одорологические следы могут использоваться и в ходе дальнейшего расследования в целях получения доказательственной информации. Для правильного определения возможных мест наличия запаховых следов и объектов-запахоносителей необходимо моделировать поведение преступников на месте происшествия, обращая внимание на места их длительного пребывания.

Обнаружение твердых частиц, капель жидкости, непосредственно отделившихся от тела человека в связи с его физиологической и практической деятельностью, - дело трудное, требующее от следователя и других участников осмотра места происшествия тщательного анализа механизма предполагаемого преступления, выдвижения и проверки версий о вероятном поведении преступника. При обнаружении этих объектов необходимо сфотографировать место обнаружения и/или сам объект, если это возможно, затем, если объект мелкий, нужно с помощью пинцета поместить его в стеклянную пробирку с притертой пробкой. Емкость можно закупорить корковой либо полиэтиленовой пробкой, что позволит в будущем без разгерметизации емкости шприцем брать через пробку воздух с молекулами запаха.

Обнаружение на месте происшествия одежды, обуви, постоянно носимых личных вещей, предметов туалета и сопутствующих объектов обычно не представляет труда. Но работа с ними, как с источниками одорологической информации, требует особой осторожности. Например, следует помнить, что всякое прикосновение руки к обнаруженному предмету «загрязняет» его запаховую характеристику. При длительном же нахождении в руках одорологическая информация утрачивается. При работе с объектами, являющимися следами-источниками запаха человека, необходимо соблюдать следующие правила:

- прежде всего, предмет следует осмотреть на наличие следов папиллярных узоров и посторонних микро- и макрочастиц - следов наложений;

- чтобы не повредить вероятно имеющиеся следы папиллярных узоров пальцев рук, необходимо вначале продумать, как мог держать этот предмет преступник;

- осматривая мелкие предметы, следует пользоваться пинцетом, а крупные - исследовать только в перчатках;

- после осмотра предмет-источник запаха следует законсервировать, то есть поместить в герметически закрывающуюся емкость. Для небольших предметов либо вещей (шапка, перчатка, шарф, носовой платок, очки, авторучка и тп.) используются стеклянные банки с притертыми пробками. Если нет последних, банку можно закрыть полиэтиленовой крышкой, а шель по кругу замазать пластилином. Крупные предметы и вещи помещают в полиэтиленовые мешки и завязывают, создавая герметичность упаковки ${ }^{59}$.

Кроме того, к особенностям, характерным для поиска и изъятия пахучих веществ человека, относятся:

- создание условий, обеспечивающих максимальную сохранность запаховых следов (следует накрыть следы каким-либо ящиком или коробкой, выставить оцепление и т.д.);

- ограничение числа участников оперативно-следственной группы только лицами, без которых это действие может утратить процессуальное значение либо оказаться малоэффективным;

- соблюдение правил поведения и передвижения, исключающих возможность разрушения следов или их загрязнения посторонними пахучими веществами (участники осмотра должны находиться в пределах отведенного участка, передвигаться только по разрешению руководителя осмотра, не курить и не создавать сквозняков);

- выполнение строгой очередности поиска и изъятия запаховых следов;

- поиск и изъятие запаховых следов должны предшествовать работе с любыми другими следами или предметами, которые могут стать вещественными доказательствами ${ }^{60}$

Следами-источниками запаха человека могут быть, например: орудия совершения преступления (нож, пистолет, палка и т.п.), предметы труда, инструменты и все иные материальные объекты, на которых могут быть следы преступника. Они могут быть нанесены непосредственно (например, рукой, босой ногой) либо опосредствованно (допустим, обувью). Однако из-за непродолжительного контакта следообразующего объекта со следовоспринимающим такие следы менее устойчивы во времени. Кроме того, они иногда находятся на объектах, которые невозможно изъять.

Обнаружение и консервация запаховых следов, оставленных на сравнительно небольших предметах, таких, как топор, молоток, обломок кирпича, кусачки, отвертка и т.п., производят так же, как и следов, оставленных на предметах одежды и личных вещах. После соответствующего осмотра они подлежат консервации в стеклянных либо полиэтиленовых емкостях.

Фиксация следов-источников запаха с объектов, которые нельзя изъять вместе со следом либо когда эти объекты необходимы для другого исследо-

${ }_{59}$ Шамонова Т.Н. Криминалистическая одорологическая экспертиза: методические рекомендации. М., 2001. 38 с.

${ }^{60}$ См.: Шамонова Т.Н. Указ. соч. С. 13 
вания, имеет свои особенности (например, фиксация запаха со следа обуви на полу, асфальте, земле, снегу). В этих случаях применяется специально разработанный прибор отбора запаха ПОЗ. Он включает набор шприцов, стеклянных бутылок, банок, полиэтиленовых фляг объемом 0,5-1 л, полиэтиленовых кульков и мешков. Запаховый след можно помещать и в металлическую эмалированную емкость. Методика отбора следа запаха относительно проста. К поверхности следа подносят иглу шприца объемом 100-200 см³ и, перемещая его на высоте 1-2 см, производят забор воздуха с молекулами запаха. Полученную порцию помещают в стеклянную емкость. Иногда последнюю переворачивают вниз горловиной. Указанную процедуру отбора проделывают три-четыре раза, затем емкость герметически закрывают и соответствующим образом опечатывают. В емкость перед закачкой воздуха со следами запаха можно поместить небольшой клочок стерильной ваты или марлевые тампоны, что уменьшает движение газовой смеси в банке и позволяет надежнее сохранить запаховый след. Кроме того, вата или марлевые тампоны адсорбируют молекулы и таким образом сохраняют след запаха. Иногда в случае отсутствия шприца можно производить отбор газовой смеси полиэтиленовой флягой, которую необходимо сжать, поднести горловиной к следу и затем постепенно разжимать. Фляга расправится и втянет с поверхности следа воздух с молекулами запаха. После этого флягу быстро закрывают, по возможности герметично. Аналогично производится отбор следов запаха с поверхности одежды, которую направляют на экспертизу, а также с громоздких предметов, на которых имеются малозаметные следы пальцев рук в виде мазков.

Следы-источники собственного запаха объекта представляют собой твердые, сыпучие и жидкие предметы (вещества), которые отличаются только тем, что их одорологическая информация отображает собственные свойства объекта и не содержит сведений о человеке. На месте происшествия такими объектами могут быть все предметы (тела), которых не касался преступник во время совершения преступления (предметы обстановки, вещи, животные, насекомые, растения, наркотики, фармацевтические препараты, винно-водочные изделия, самогон, ароматические вещества, горюче-смазочные жидкости). Методика работы с ними на месте происшествия и применяемые технические средства те же, что и рассмотренные ранее.

От одного объекта-источника можно отбирать несколько емкостей воздуха со следами запаха благодаря их свойству делимости, что позволяет неоднократно использовать один и тот же источник запаха для повторных либо контрольных исследований на различных этапах расследования преступлений.

\section{Глава 8}

\section{ЕСЛИ СЛЕДОВАТЕЛЬ «НА ВЫ» С КОМПЬЮТЕРОМ: СОВЕТЫ ОПЫТНОГО ЮЗЕРА}

Несмотря на то что в настоящее время $100 \%$ следователей и дознавателей владеют компьютером, по нашим данным, более $93 \%$ из них пользователи начального уровня. А это значит, что не каждый практический работник обладает элементарными навыками организации своей работы даже с простейшим пакетом программ.

В то же время у подавляющего большинства общественных помощников, практикантов дома есть компьютеры, причем, чаще всего, более современные и мощные, чем служебные. Это значит, что при необходимости молодой человек может и должен помочь следователю разобраться хотя бы в элементарных вопросах.

Как упорядочить папку «Мои документы» в компьютере ${ }^{61}$. Часто бывает, что у практических работников, особенно молодых и не очень опытных, дела, материалы, отчеты на жестком диске ПК не систематизированы, расположены в хаотическом порядке. В этом случае не только посторонний, но зачастую и он сам не всегда может быстро найти нужную информацию.

Поэтому предлагаем, в первую очередь, сделать следующее. Первоначально в «Моих документах» для следователя нужно создать директорию с его фамилией. В ней нужно создать 3 поддиректории: 1) «Уголовные дела»; 2) «Отказные материалы»; 3) «Отчеты».

Папку «Уголовные дела» нужно разбить на 2 подпапки: «Текущие дела» и «Архив». В директории «Текущие дела» должны содержаться поддиректории уголовных дел, находящихся в производстве. В названии папки уголовного дела лучше использовать номер дела и фамилию обвиняемого или потерпевшего. Так в последующем легче будет его найти. В указанной папке нужно сохранять все рабочие документы по данному уголовному делу (планы, запросы, экспертизы, допросы и т.д.). Внутри нее можно разместить и заполнять следующие папки: «Движение дела», «Допросы», «Меры пресечения», «Обвинения», «Обыски, выемки», «Осмотры и приобщения», «Запросы и поручения», «Прочее» (для размещения личных записей по уголовному делу и временных документов).

${ }_{61}$ Электронные шаблоны этих папок (незаполненных) размещены на сайте labatr.bsu.ru, ссылка на данное руководство, электронное приложение № 8. Подробнее см. 1.4. 
В «Архиве» следует создавать по годам папки, в каждой из которых должны содержаться следующие поддиректории: «Суд», «Приостановление», «Прекращение», «Передача», «Подследственность». В папке конкретного года находятся все дела, по которым решение было принято в соответствующем году (направлено в суд, прекращено и т.д.).

В зависимости от того, на каком этапе находится следствие, в той папке и будет находиться конкретная поддиректория уголовного дела Это значительно упрощает работу следователя, как по текущим делам, так и по делам, по которым уже было принято процессуальное решение. Так, зачастую по приостановленным делам через длительное время следователю приходится искать в компьютере нужные сведения.

Директорию «Отказные материалы» следует разделить на 2 части. Первая - текущие материалы. Каждый из материалов должен иметь свою поддиректорию с именем. В название папки целесообразно включать фамилию потерпевшего или иное знаковое слово, которое в будущем облегчит поиск материала. Вторая часть состоит из «Архива», который, в свою очередь, разделен на поддиректории по годам. В архив перемещаются отказные материалы, по которым принято правовое решение.

В директории «Отчеты» также целесообразно по годам накапливать все файлы, связанные с отчетом следователей о проделанной работе за неделю, месяц, квартал и год. Отдельно в папке следователя необходимо записать одну из существующих следственных программ, где содержатся образцы процессуальных документов, методические рекомендации, памятки и т.д.

Вновь напоминаем следователю - неопытному юзеру: будьте крайне внимательны с заполнением шаблона предыдущего документа! В последующем это может привести к серьезным техническим или процессуальным ошибкам (от предыдущего документа может случайно остаться номер дела, даты, некоторые анкетные данные ненужного теперь лица и т.д.). Иногда лучше копировать образец нужного бланка в конкретную рабочую папку (конкретное уголовное дело) и там заполнять.

Далее приводим еще несколько кратких советов о том, как общественный помощник, добросовестный практикант могут добиться искренней благодарности и уважения коллектива следственного отдела, прокуратуры, любого другого правоохранительного подразделения Известны случаи, когда за кандидатуру практиканта перед руководителем СУ СК по субъекту РФ ходатайствовало руководство районного следственного отдела. Его приняли на работу в основном только потому, что он организовал коллективу всего 5 пунктов из нижеследующего списка.

\section{Краткие советы}

\section{о том, чем продвинутый юзер может помочь следователю,} правоохранительному подразделению 62

1. Организовать установку на компьютеры организации нескольких вариантов (систему) защиты информации: новый антивирус с регулярным обновлением; пароли; DVD-райтер с возможностью записи на диски; копирование директорий в локальную сеть и т.п.

2. Загрузить в память компьютеров обучающие и организующие программы: «АРМ следователя», органайзеры, «блокнот», «напоминалки», «десятипальцевый метод» печати, программы синхронизации мобильного телефона с компьютером и т.п.

3. Загрузить из Интернета или других источников новые правовые базы данных (если в организации нет СПС «Консультант Плюс», «Гарант» и т.п.), например, бюллетени ВС РФ, все кодексы, приказы Генерального прокурора РФ и др. ${ }^{63}$ Следует не реже одного раза в месяц обновлять эти данные.

4. Найти и загрузить в память компьютера некоторые специализированные программы для следственной работы: «Фоторобот», «Дактилоскопия».

5. Организовать на месте практики доступ в Интернет; помочь следователям, у кого до сих пор нет электронного адреса, завести собственный бесплатный «почтовый ящик», подписаться, как минимум, на ежедневную рассылку федерального и иного законодательства и юридической прессы (см., например, сайт http://www. garant.ru).

6. Загрузить в память компьютера шаблоны процессуальных и иных документов и адаптировать их под конкретного следователя.

7. Загрузить в память компьютера шаблоны всех отчетных документов и каждый адаптировать под конкретного следователя. Загрузить в память компьютера некоторые информационные ресурсы: карты, базу данных по населенному пункту (адреса, телефоны организаций и др.), словари, программы автоматического перевода текстов, юридические и иные электронные энциклопедии и др.

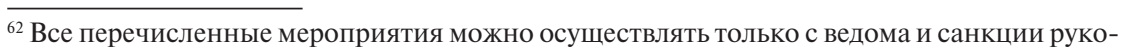
водства правоохранительного органа

${ }^{63}$ Некоторые сайты в Интернете на законных основаниях предоставляют доступ к таким ресурсам.
} 
8. Загрузить в память компьютера максимальное количество методической, учебной литературы, материалов следственной практики и др. ${ }^{64}$

9. Предложить куратору свою помощь в регулярном архивировании и надежном сохранении всех его документов и ресурсов.

10. Найти куратору толкового программиста, который на приемлемых условиях согласится регулярно обслуживать служебный компьютер по иным, более сложным вопросам ${ }^{65}$.

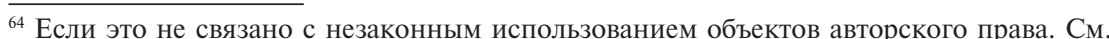
например, ст. 146 УК РФ.

65 Здесь следует уточнить, что в большинстве городов в штате следственных подразделений, например, следственных управлений Следственного комитета при прокуратуре РФ имеются специалисты по обслуживанию компьютерной техники. Во многих управлениях изданы приказы, запрещающие самостоятельное вмешательство в программное обеспечение служебного компьютера. Поэтому рекомендация применима только после согласования с руководством, например, для отдаленных сельских следственных подразделений.

\section{Глава 9 \\ СОСТАВЛЕНИЕ ОТДЕЛЬНЫХ ПРОЦЕССУАЛЬНЫХ ДОКУМЕНТОВ}

Как известно, большую часть рабочего времени следователь тратит собственно не на производство следственных и иных процессуальных действий, а на фиксацию их результатов, то есть на составление разнообразных документов. Практикант и, само собой, общественный помощник, как это предписано п. 18 Положения, может очень существенно сэкономить драгоценное время следователя, дознавателя, взяв на себя составление проектов некоторых процессуальных документов.

Анализ результатов работы практикантов в четырех субъектах РФ показал, что следователи поручают молодежи составление проектов далеко не всех процессуальных документов. Увы, нечасто практический работник может себе позволить доверить практиканту составление постановления о привлечении в качестве обвиняемого ${ }^{66}$, протоколов допросов обвиняемых, основных свидетелей и потерпевших по делу. Вместе с тем добросовестному, хорошо подготовленному и неленивому общественному помощнику, практиканту, при условии подробного инструктажа и демонстрации образцов, следователь может доверить составление проектов следующих документов:

постановление о признании потерпевшим;

постановление о признании гражданским истцом;

постановление о признании и приобщении к уголовному делу вещественных доказательств;

постановление о производстве обыска (выемки) ${ }^{67}$;

постановление о производстве личного обыска;

постановление о возбуждении перед судом ходатайства о производстве обыска (выемки) либо осмотра в жилище;

постановление об этапировании;

постановление об избрании меры пресечения;

$\overline{{ }^{6}}$ Тем не менее в следующем параграфе изложены рекомендации по составлению текста обвинения. Но они ориентированы больше на молодых следователей и общественных помощников.

${ }^{67}$ И другие документы, связанные с обыском, личным обыском. 
постановление об отказе либо удовлетворении ходатайства;

постановление о назначении экспертизы;

и другие документы, составление проектов которых общественным помощником, практикантом, по мнению следователя, и с учетом конкретных обстоятельств дела не должно вызвать особых сложностей ${ }^{68}$.

При этом проекты необходимо выполнять только на персональном компьютере, чтобы в дальнейшем можно было легко внести в электронный текст изменения и дополнения.

Внимание! Необходимо, чтобы следователь тщательно изучил составленный проект и указал на допущенные ошибки. В отношении добросовестных помощников давно замечено, что при составлении несложных документов только первые два-три раза ему приходится делать замечания. Дальше - легче... При составлении проектов протоколов допросов в распоряжении следователя имеются два варианта действий:

- проводить допрос самостоятельно с привлечением практиканта в качестве лица, составляющего протокол, указывая ему на обстоятельства, подлежащие внесению в документ. Проверить перед подписанием, подписать;

- позволить практиканту самостоятельно провести допрос свидетеля или потерпевшего в своем присутствии с составлением протокола самостоятельно. Проверить протокол перед подписанием, подписать ${ }^{69}$.

Особо следует рассмотреть рекомендации о привлечении практикантов к составлению проекта обвинительного заключения. Для следователя это очень затратная по времени работа, которую можно поручить общественному помощнику. Большую часть документа занимает так называемый перечень доказательств обвинения и защиты (п.п. 5 и 6 ч. 1 ст. 220 УПК РФ).

Хотя в кодексе используется именно этот термин, на практике необходимо «расписывать» краткое содержание и результаты оценки того или иного доказательства, то есть описывать показания свидетелей, потерпевших, обвиняемых, произведенные выемки, осмотры, обыски, экспертизы и т.д.

${ }^{68}$ Напоминаем, что примеры этих и других документов можно скачать на сайте labatr.bsu.ru, ссылка на данное руководство, электронное приложение № 9 .

${ }^{69}$ Вновь повторим, что такой вариант допроса может вызвать у суда и стороны защить сомнения с точки зрения допустимости полученного доказательства. Возникает вопрос «Надлежащий ли субъект проведения следственного действия?» Обязательно посоветуйтесь с руководителем следственного органа!
Законом не предусмотрена последовательность расположения доказательств обвинения в тексте обвинительного заключения. Вот один из распространенных вариантов изложения:

- основания и поводы для возбуждения уголовного дела (рапорт, заявление, протокол явки с повинной и т.д.);

- результаты экспертиз по делу;

- результаты проведенных осмотров места происшествия, трупа, дополнительных осмотров;

- результаты проведенных выемок, обысков, личных обысков;

- результаты осмотров изъятых предметов и документов;

- показания потерпевших;

- показания свидетелей (как правило, в хронологическом порядке по времени их допроса или последовательности описываемых ими событий);

- результаты проведенных очных ставок;

- показания подозреваемых;

- показания обвиняемых;

- иные документы ${ }^{70}$.

При описании доказательств защиты можно расположить их в следующем порядке:

- результаты экспертиз, если они свидетельствуют в пользу обвиняемого;

- показания свидетелей в пользу обвиняемого (в том числе и по характеризующим данным);

- показания подозреваемого;

- показания обвиняемого (в случае, если он допрашивался неоднократно - в хронологической последовательности);

- характеризующие личность обстоятельства (положительные характеристики и проч.).

Также помошнику и практиканту необходимо знать, что если лицо обвиняется в совершении нескольких преступлений, то по каждому эпизоду (составу преступления) необходимо повторно указывать все доказательства обвинения и защиты. В случае, если по делу обвиняется несколько лиц, то по каждому лицу необходимо указывать все доказательства обвинения и зашиты, касаюшиеся его лично.

${ }^{70}$ Есть и иная практика: первыми излагаются показания потерпевших, свидетелей, обвиняемого и далее остальные доказательства. 


\section{Глава 10}

\section{ОСОБЕННОСТИ ДОПРОСА}

Уважаемые следователи! В этом разделе речь будет идти о допросе - следственном действии, без которого не обходится расследование ни одного уголовного дела. С одной стороны, это самое распространенное следственное действие - большую часть протокольных материалов уголовного дела составляют протоколы допроса, а их подготовка и производство занимают примерно две трети работы следователя. С другой, это сложный способ получения доказательств, требующий от нас высокой общей и профессиональной культуры, знания психологии людей, владения тактическими приемами допроса. Поэтому, уважаемые следователи, чтобы полноценно использовать содействие помощника или практиканта, необходимо не только поручить им изучить законодательство, соответствующую учебную и практическую литературу, но и обеспечить им возможность присутствия, а желательно и посильного участия при производстве допросов, например, выполнение обеспечивающих функций

Тактико-криминалистические и психологические рекомендации по проведению данного следственного действия содержатся во многих научных, учебных и практических изданиях. Напомним основные требования закона и отметим то, что можно поручить общественному помощнику или практиканту.

Уголовно-процессуальный закон особо регламентирует специальные требования к проведению допроса: основания для его проведения, место, время и продолжительность, круг участников, их правовой статус (ст.ст. 187-192 УПК РФ). Эти требования должны быть заранее известны помощнику (практиканту) из курса уголовно-процессуального права. Следователь может убедиться в этом, устроив молодежи неформальный зачет.

Как известно, по процессуальному положению допрашиваемых выделяются допросы: свидетеля, потерпевшего, подозреваемого, обвиняемого, эксперта, специалиста, а также несовершеннолетнего. Для любого из перечисленных видов данного следственного действия характерно в той или иной степени наличие пяти стадий:

1. Стадия подготовки к допросу.

2. Предварительная стадия.

3. Стадия свободного рассказа.

4. Вопросно-ответная стадия.
5. Стадия процессуального оформления полученных показаний (фиксация показаний).

Первая стадия является подготовительной. Она включает в себя:

1. Установление круга лии, подлежащих допросу и определение способа вызова этих лиц, на допрос.

Общий порядок вызова на допрос установлен ст. 188 УПК РФ. Лицо вызывается на допрос, как правило, повесткой, в которой указывается: кто и в качестве кого вызывается; адрес, по которому необходимо явиться; дата и время явки, а также последствия неявки без уважительных причин. Заполнение повесток, как уже указывалось в 6.5, можно поручить даже не общественному помощнику, а менее квалифицированному лицу - практиканту.

Повестка может быть не только вручена лицу, вызываемому на допрос, под расписку, но и передана телефонограммой, телеграммой, с помощью факсимильного устройства или других средств связи. Эту работу также можно поручить практиканту, предварительно проинструктировав его как указано в 6.6. Следователь должен быть уверен в том, что повестка вручена адресату. Если адресат временно отсутствует, повестка может быть вручена кому-либо из взрослых членов семьи, представителю администрации по месту работы вызываемого и т.д. Следует предупредить практиканта, что факт вручения повестки должен быть удостоверен распиской либо самого вызываемого, либо того, кому она передана, либо уведомлением почтового учреждения о вручении. В случае вызова лица на допрос по телефону в необходимых случаях составляется телефонограмма, в которой указывается не только кто, в качестве кого и в какое время вызывается на допрос, но и дата и время передачи сообщения, а также кем это сообщение передано. При этом корешок повестки (либо уведомление почтового учреждения о вручении, телефонограмму) целесообразно приобщить к материалам уголовного дела, что позволит подтвердить факт вызова на допрос, в случае отрицания этого факта вызываемым.

Не только следователь, но и любой практикант должен знать, что в особом порядке вызываются:

а) несовершеннолетние (через законных представителей);

б) содержащиеся под стражей, отбывающие наказание (через администрацию);

в) военнослужащие (через командование воинской части);

г) лица, находящиеся на территории другого государства (ст. 456 УПК Р $\left.\Phi^{71}\right)$.

${ }^{11}$ Общее правило вызова лиц, находящихся за пределами РФ, на допрос заключается в добровольности их явки (ст.ст. 8 и 12 Европейской конвенции о взаимной правовой помо- 
2. Изучение личности того, кого предполагается допросить

Собирание данных о личности допрашиваемого следователь также может поручить общественному помощнику или практиканту. Официальными документами, сведения из которых помогут изучить личность допрашиваемого ${ }^{72}$, могут быть:

а) характеристика с места работы, учебы, жительства;

б) уголовные дела (если лицо было ранее судимо или привлекалось к уголовной ответственности). При этом следует обратить внимание помощника или практиканта на то, что большую пользу приносит изучение и анализ протокола судебного заседания, поскольку в нем наиболее ярко проявляются некоторые психологические особенности личности (способ защиты, отношение к соучастникам и т.д.);

в) личное дело заключенного (если лицо отбывало наказание в виде лишения свободы). Из него можно получить информацию о поведении в исправительном учреждении об отношении с близкими и др.;

г) медицинские карты, истории болезни.

Особенно важное значение могут иметь результаты оперативно-розыскной деятельности (ОРД). Часто они помогают составить максимально полное представление о личности лица, подлежащего допросу. Напомним, помощник, практикант может составить проект соответствующего запроса в орган - субъект ОРД. Но передавать его, лично договариваться о представлении результатов ОРД, необходимо только следователю.

3. Составление плана допроса.

Планирование предстоящего допроса предполагает определение круга обстоятельств, в отношении которых предстоит получение показаний. При отсутствии у следователя четкого представления об этих обстоятельствах допрос лишается целеустремленности, в показаниях могут быть пробелы и ненужная информация (см. 6.6).

Информация, относящаяся к предмету допроса, может носить характер специальных знаний. В таких случаях следователь вправе использовать консультации специалиста, который поможет правильно сформулировать вопросы. Приглашение специалиста следователь может поручить помощнику, практиканту.

ши по уголовным делам), то есть отказ от явки на территорию РФ не влечет применение к ним санкщий или принудительных мер в запрашиваемом государстве. Запрос о вызове К ним санкций или принудительных мер в запрашиваемом государстве. Запрос о вызове
оформляется только тем должностным лицом, в производстве которого находится уголовное дело через указанные в ч. 3 ст. 453 УПК РФ органы. В запросе должны быть указаны примерные размеры денежных выплат, а также возмещаемых транспортных расходов и суточных. Запрос должен быть заверен печатью органа - инициатора запроса.

${ }^{72}$ В гл. 4 уже отмечалось, что общественный помощник (практикант) сначала оформляет проект запроса, затем передает следователю для проверки и получения его подписи
Ошибкой следователей является отказ от планирования следственного действия, что нередко является причиной того, что допросы проводятся поверхностно. Первая беседа часто носит разведывательный характер, но иногда именно она позволяет определить позицию допрашиваемого, продумать наиболее эффективные тактические приемы проведения допроса, последующих следственных действий, помогает следователю избрать оптимальную линию поведения. Планирование допроса позволяет четко определить круг вопросов, подлежащих выяснению, их последовательность, доказательства, которые могут быть предъявлены, способы их предъявления.

Письменный план предпочтительнее составлять при допросах, связанных с выяснением широкого круга обстоятельств, с использованием значительного объема исходной информации. При подготовке к иным, не таким сложным допросам допустимо составление плана в виде перечня вопросов. Иногда достаточно мысленного планирования, что позволит предусмотреть несколько вариантов развития следственной ситуации.

4. Непосредственная подготовка к допросу на месте его проведения

Закон прямо предусматривает применение в ходе допроса таких приемов и средств, как предъявление доказательств, оглашение протоколов других следственных действий, воспроизведение аудио- и видеозаписи или киносъемки следственных действий; изготовление допрашиваемым лицом схем, чертежей, рисунков, диаграмм (ч.ч. 3, 4 ст. 190 УПК РФ). Помощник или практикант по поручению следователя могут обеспечить предстоящий допрос:

- необходимыми техническими средствами (обязательно предвари-

тельно проверить их исправность и готовность к работе);

- материалами фиксации его хода и результатов (бланки протоколов, бумага, пишущие принадлежности, исправный компьютер, программное обеспечение и т.д.);

- подборкой вещественных доказательств, протоколов других следс-

твенных действий, иных объектов, необходимых для допроса.

При этом заранее следует предусмотреть меры обеспечения сохранности доказательств, предупредить попытки допрашиваемого их уничтожить, повредить. Для этого помощнику, практиканту в случае необходимости можно поручить изготовить ксерокопии нужных документов. Тогда при допросе можно предъявлять их, а не подлинники

Также на помощника или практиканта может быть возложено создание необходимых условий в помещении для допроса: устранение, насколько это возможно, источников шума, удаление из помещения посторонних лиц, подготовка стола следователя, чтобы на нем не было лишних предметов, отвлекающих внимание и т.д. 
На помощника или практиканта также могут быть возложены обязанности:

- обеспечения участия лиц, которые в соответствии с уголовно-процессуальным законом при определенных условиях должны присутствовать при проведении допроса. Речь идет о переводчике (ч. 1 ст. 189 УПК РФ), специалисте (ст. 58 УПК РФ), педагоге (ч. 1 ст. 191 УПК РФ), законном представителе несовершеннолетнего (ст.ст. 191, 426 УПК РФ), понятых (ч. 3 ст.167 УПК РФ), защитника подозреваемого, обвиняемого;

- помочь следователю найти необходимые транспортные средства и обеспечить охрану, если это может потребоваться.

Кроме этого, помощнику, практиканту может быть поручено принятие мер к тому, чтобы вызванные на допрос по одному уголовному делу лица не могли общаться между собой.

На предварительной стадии допроса происходит заполнение анкетной части, фиксацию которой в протоколе может выполнять помощник или практикант. На этой стадии следователю необходимо:

a) назвать свою фамилию, имя и отчество, должностное положение;

б) убедиться в личности явившегося путем ознакомления с документом, удостоверяющим личность;

в) разъяснить допрашиваемому, в каком качестве и по какому уголовному делу он допрашивается, порядок проведения следственного действия. Особенно важным является разъяснение права на отказ от показаний (свидетельский иммунитет ч. 2 ст. 11 ; п. 3 ч. 2 ст. 42 ; п. 2 ч. 4 ст. 46 ; п. 3 ч. 3 ст. 47; п. 1 ч. 4. ст. 56 УПК РФ) и последствий отказа от иммунитета;

г) предупредить свидетеля и потерпевшего об уголовной ответственности за отказ от показаний и за дачу ложных показаний (за исключением несовершеннолетних, которым лишь разъясняется необходимость говорить правду);

д) объяснить допрашиваемому порядок составления и подписания протокола, а также то, что ему будет предоставлено право вносить любые поправки, изменения и дополнения в протокол (ч. 6 ст. 166; ч. 2 ст. 167 , ч. 6 ст.190 УПК РФ);

г) предупредить допрашиваемого о применении технических средств.

Третья стадия - это допрос по существу. Хотя УПК РФ не требует начинать допрос по существу дела со свободного рассказа допрашиваемого лица, как это имело место в УПК РСФСР (ч. 5 ст. 158), такой порядок ведения допроса является, как правило, оптимальным. Свидетелю и потерпевшему предлагается рассказать все известное им по обстоятельствам, в связи с которыми они вызваны на допрос. Подозреваемому и обвиняемому - об обстоятельствах, вызвавших подозрение или составляющих содержание обвинения.

В этой стадии не рекомендуется без необходимости перебивать допрашиваемого. Вмешиваться в его рассказ целесообразно только при явном отклонении от темы допроса. На данном этапе помощник или практикант, на усмотрение следователя, могут либо фиксировать показания допрашиваемого в протоколе (следователь указывает на обстоятельства, подлежащие внесению в документ) ${ }^{73}$, либо наблюдать за особенностями поведения допрашиваемого, изменением его психического состояния. Признаками изменения психического состояния могут быть: интонация, изменение темпа речи, паузы; выражение глаз и направление взгляда; цвет лица и выступление пота; жесты, поза, движение рук и т.п. Конечно, выводы по результатам такого наблюдения носят вероятностный характер, но тем не менее внимание на указанные признаки обращать следует. Именно здесь следователю может понадобиться помощь общественного помощника или практиканта. Им можно поручить такое наблюдение, и в случае выявления указанных признаков, следует обратить на это внимание куратора.

Желательно, чтобы до проведения допроса более квалифицированный, по сравнению с практикантом, общественный помощник ознакомился с материалами дела. Это позволит ему в ходе следственного действия сопоставлять показания со сведениями, имеюшимися в деле, обратить внимание на информацию, которая ранее вообще не была известна следователю, либо уточнение которой у данного лица не предполагалось. Разумеется, все это может помнить и сделать сам следователь. Но практика показывает, что квалифицированная помощь в этом вопросе ему не повредит. Особенно с учетом высокой загруженности большинства наших коллег.

В четвертой - «вопросно-ответной» стадии, следователь, в зависимости от полученной в ходе свободного рассказа информации и характера сложившейся на данном этапе ситуации, использует необходимые тактические приемы, задает уточняющие, дополняющие, контрольные, напоминающие и другие вопросы, предъявляет доказательства ${ }^{74}$.

${ }^{73}$ Варианты участия в этой процедуре общественного помощника, практиканта, с точки зрения допустимости доказательств, рассмотрены в гл.гл. 4 и 6.6 .

${ }^{74}$ Вопросы тактики различных видов допроса достаточно полно раскрыты в учебниках криминалистики и специальных изданиях. См., например: Ливщии Е.M., Белкин Р.C. Тактика следственных действий. М.: Новый Юристь, 1997. 505 с.; Питерцев С.К., Степанов А.А. Тактика допроса. СПб.: Питер, 2001. 146 с. и др. 
Закон устанавливает, что следователь свободен в выборе тактики допроса. Категорически запрещены только наводящие вопросы (ч. 2 ст. 189 УПК РФ), то есть те, в самой формулировке которых содержится подсказка желаемого ответа. К постановке вопроса необходимо подходить осторожно, чтобы предотвратить возможность внушения. Он должен быть сформулирован так, чтобы допрашиваемый не мог извлечь из него никакой новой информации об обстоятельствах дела и вынужден был опираться только на собственную память. Запрет формулировки наводящих вопросов относится не только к следователю, но и к другим участникам допроса (например, к адвокату). Если присутствующее лицо задает наводящий вопрос, следователь должен его отвести, что отражается в протоколе.

Для того чтобы допрос был проведен успешно, следователь, как правило, должен представлять себе, какую примерно информацию, с помощью каких приемов и средств он намерен получить от допрашиваемого. Следует адаптировать избираемую тактику к возрасту, образованности, темпераменту, профессии и другим характеристикам, которые были получены при подготовке к допросу в ходе изучения личности допрашиваемого. Следователь всегда должен думать над тем, как будет воспринят его вопрос, поэтому часто возникает необходимость приноравливаться к интеллектуальному уровню собеседника. Задаваемые вопросы должны быть точными, ясными и однозначными для допрашиваемого. В противном случае он может не понять поставленного вопроса и дать неправильный ответ (на что нередко ссылаются на повторных допросах и в суде).

Иногда само поведение допрашиваемого наводит на мысль, что в последующем он может отказаться от своих показаний и заявить, что неправильно понял вопрос, а потому и дал такой ответ. В подобной ситуации целесообразно не только заносить в протокол каждый из вопросов и просить допрашиваемого подписывать каждый из его ответов, но и начинать фиксацию ответа в протоколе словами: «Мне понятен смысл вопроса».

Еще одним фактором, препятствующим изменению показаний в дальнейшем, является их собственноручная запись допрашиваемым.

В протоколе допроса желательно избегать многозначных слов. Ведь если в устной речи, встретившись с ошибочным пониманием, можно устранить недоразумение, то в письменной этого сделать нельзя. Поэтому при допросе необходимо уточнять, конкретизировать все недостаточно определенные, нечеткие выражения.

Кроме того, следователю приходится получать информацию от людей самых различных профессий, часто использующих такие термины и формулировки, которые понятны только с учетом знаний этой профессии. Необходимо проверять правильность восприятия тех или иных понятий посредством выяснения их содержания, изменением словесных формулировок, иными способами, позволяющими раскрыть эти понятия.

Следующая, пятая стадия - фиксация показаний допрашиваемого, является важной стадией допроса, поскольку без правильной процессуальной фиксации хода и результатов следственное действие теряет свою доказательственную силу.

Как известно, основным средством фиксации хода и результатов допроса является составление протокола. Он состоит из четырех частей: анкетной; изложения свободного рассказа допрашиваемого; записей поставленных допрашиваемому вопросов и его ответов; удостоверительной части, в которой содержатся отметка об ознакомлении допрошенного с записью показаний и удостоверение его, других участников следственного действия, подписями правильности протокола.

Как уже отмечалось ранее, в случае, если такая практика принята в вашем регионе, следственном подразделении, фиксация показаний может быть поручена помощнику или практиканту. Как правило, это в некоторой степени повышает эффективность и динамику допроса, поскольку следователь не теряет психологический контакт с допрашиваемым, отвлекаясь на составление протокола. Помощнику, практиканту должны быть известны основные требования к протоколированию показаний. Отметим некоторые из них.

Показания заносятся в протокол от первого лица и по возможности дословно (ч. 2 ст. 190 УПК РФ), то есть с использованием терминологии самого допрашиваемого лица. Недопустимо в протоколе записывать «юридические штампы». Нецензурные выражения, жаргонные слова в протокол не записываются, а их смысл излагается допрашиваемым другими словами. Содержание специальных терминов, употребленных в ходе допроса, также должно быть раскрыто самим допрашиваемым.

Следует обратить внимание помощника (практиканта) на нежелательность слишком частого использования в протоколе личных местоимений, поскольку могут возникнуть разночтения. В случае употребления допрашиваемым лицом местоимений целесообразно указывать в скобках, кто имеется в виду. Недопустимо по собственному усмотрению сокращать полученные показания, изменять их в соответствии со своими представлениями о ходе вещей.

Вопросы и ответы на них записываются в той последовательности, которая имела место в ходе допроса. При этом в протокол записываются все без исключения вопросы, в том числе и те, которые были отведены следователем или на которые отказалось отвечать допрашиваемое лицо, с указанием мотивов отвода или отказа. 
В протоколе отражается предъявление в ходе допроса доказательств и данные в связи с этим пояснения, а также сведения о причинах и длительности остановки аудио-, видеозаписи.

Изготовленные допрашиваемым графические изображения (планы, схемы, рисунки и т.д.), дополняющие его показания, обязательно приобщаются к протоколу.

Допрашиваемое лицо должно быть ознакомлено с протоколом допроса путем личного прочтения либо оглашения его следователем. Способ выбирает сам допрашиваемый. Он имеет право на уточнение и дополнение своих показаний, а также вправе просить о внесении в протокол замечаний. Протокол, дополнения и уточнения к нему подписывается всеми участниками допроса. Допрашиваемый своей подписью удостоверяет в протоколе:

- факт разъяснения ему его прав и обязанностей;

- факт его ознакомления с протоколом;

- правильность записи показаний, уточнений и дополнений.

Допрашиваемый подписывает каждую страницу протокола. В конце протокола допроса целесообразна расшифровка подписи допрашиваемого с указанием фамилии, имени и отчества.

Законом предусмотрена возможность применения для фиксации хода и результатов допроса технических средств, таких, как фото- и киносъемка, аудио- и видеозапись. Эту деятельность следует поручить общественному помощнику, практиканту. Повторим, что в случае использования помощника в качестве специалиста, осуществляющего видеозапись или фотографирование, необходимо его тщательно проинструктировать в порядке, описанном в $7.2^{75}$

Известно, что видео- и звукозапись в плане фиксации показаний имеют ряд преимуществ по сравнению с протоколированием допроса. В частности, письменная речь не передает заминок с ответом, длительности пауз, внезапной хрипоты или дрожания голоса, изменений его тембра и т.д. Поэтому аудио- и видеозапись являются эффективными тактическими средствами, например, против изменения показаний допрашиваемым, а также при подозрении в фальсификации протокола следователем.

В необходимых случаях следует фиксировать путем аудио- и видеозаписи весь ход допроса, всякий раз оговаривая причину остановок и перерывов записи, время, в течение которого запись не производилась.

75 Также в гл. 12 отмечены некоторые важные моменты, позволяющие избежать проблем дальнейшего использования доказательств, полученных с применением технических средств.
Эти данные обязательно должны найти отражение в протоколе, например, в виде таких фраз: «звукозапись остановлена в ... часов ... минут в связи с тем, что в кабинет вошел...», «звукозапись возобновлена в ... часов ... минут». При отсутствии подобных оговорок, аудио- или видеозапись не будет признана доказательством, если, например, подсудимый заявит о применении к нему недозволенных методов допроса.

Применение аудио- и видеозаписи допроса особенно целесообразно в следующих случаях:

а) для закрепления результатов допроса, когда допрашиваемые не смогут по уважительным причинам явиться в суд;

б) в случае, если несовершеннолетние или другие лица обладают трудно передаваемыми речевыми особенностями;

в) для закрепления показаний раненых и больных, когда существуют опасения за их жизнь и здоровье;

г) для закрепления показаний, полученных с помощью переводчика, для контроля за качеством перевода;

д) для закрепления показаний, полученных в другом регионе на основании следственного поручения;

е) для закрепления результатов допроса глухонемых. Аудио- и видеозапись сохраняют подлинные жесты и мимику допрашиваемого, что дает возможность при необходимости проверить качество перевода с языка глухонемых.

По окончании допроса с применением технических средств аудиои видеозапись полностью воспроизводятся допрашиваемому, который своим заявлением удостоверяет ее правильность. Эту несложную, но затратную по времени процедуру также можно поручить общественному помощнику, практиканту. Им, как и следователю, не стоит забывать, что должны быть записаны все дополнения и поправки к показаниям. Следует помнить, что в протоколе допроса в соответствии с законом должны содержаться: отметка о применении технических средств и уведомление об этом допрашиваемого, сведения о технических характеристиках и условиях применения этих средств, заявления допрашиваемого по поводу их применения, отметка о воспроизведении записи допрашиваемому, удостоверение правильности протокола и аудио- и видеозаписи допрашиваемым и следователем, а также теми участниками допроса, присутствие которых обязательно.

Полученные материалы прилагаются к протоколу допроса и хранятся при деле. 


\section{Глава 11}

\section{ОСОБЕННОСТИ ПРЕДЪЯВЛЕНИЯ ДЛЯ ОПОЗНАНИЯ}

Уважаемые следователи! В настоящей главе речь пойдет об одном из наиболее сложных в организационном и процессуальном плане следственных действий - о предъявлении для опознания. Сложность его определяется целым рядом факторов. Здесь и жесткие процессуальные рамки, и разнообразие объектов опознания, и необходимость приглашения целого ряда участников (особенно при опознании живых лиц), и использование специальной техники, и мн. др.

Изучение практики показывает, что вы, уважаемые коллеги, часто с большой неохотой проводите это следственное действие, да и то, как правило, в случаях, когда без него просто нельзя обойтись. Не стоит скрывать и тот прискорбный факт, что по количеству допускаемых ошибок и нарушений закона, влекуших признание доказательств недопустимыми, это следственное действие относится к числу «лидеров».

Мы предлагаем достаточно универсальный и апробированный практикой подход, с помощью которого это мероприятие можно проводить с меньшими усилиями, притом более эффективно и качественно. Речь, конечно же, как и ранее, идет о привлечении к его проведению общественного помощника или практиканта.

Предлагаем краткий алгоритм подготовки общественного помощника или практиканта к участию в работе по предъявлению для опознания:

1. Для начала поручите изучить, перечитать заново учебную и учебнопрактическую литературу по криминалистической тактике в целом и по тактике предъявления для опознания, в частности. Если считаете нужным, примите своеобразный зачет.

2. Направьте его к опытному специалисту или эксперту ЭКО (ЭКУ). Попросите последнего провести с вашим помощником ряд консультаций по поводу работы с криминалистической техникой в рамках данного следственного действия.

3. По возможности несколько раз возьмите его на предъявление для опознания в качестве наблюдателя. Пусть смотрит и запоминает. Можно направить его на это следственное действие, проводимое другим, главное - достаточно квалифицированным следователем.

4. Заранее познакомьте общественного помощника, практиканта с соответствующей криминалистической техникой: служебным фотоаппара- том и видеокамерой, сменными объективами, кольцами, вспышками, штативами и т.п. Поручите внимательно изучить руководства к эксплуатации всех устройств и нести личную ответственность за их постоянную исправность и готовность к работе: следить за зарядом батарей, заполнением карты памяти на цифровом фотоаппарате и т.д.;

5. Покажите общественному помощнику, практиканту типовой результат предстоящей процессуальной деятельности:

• протоколы предварительного допроса опознающих;

- протоколы предъявления для опознания;

- таблицы, фототаблицы, видео- и аудиозаписи, другие приложения к протоколам;

- приговоры судов со ссылками на соответствующие доказательства и другие документы по уголовным делам, законченным производством ${ }^{76}$.

6. Обучите составлению всех этих процессуальных документов. Поручите писать их проекты, можно даже по выдуманным следственным ситуациям. Расскажите о личных предпочтениях и пожеланиях;

7. Ознакомьте с содержанием этого параграфа.

Теперь ваш общественный помощник, пожалуй, готов к участию в предъявлении для опознания. Только поначалу тщательно контролируйте его работу.

Как известно, любому следователю предъявление для опознания - это специфическая форма идентификации, объектами которой могут быть:

- человек;

- предметы;

- труп.

Следует обратить внимание на то, что в ч. 1 ст. 193 УПК РФ говорится о возможности предъявления для опознания только трех групп объектов: человека (лица); предмета; трупа. Но традиционно даются рекомендации ученых по возможности проведения опознания животных, участков местности, строений, квартир в многоквартирных домах и других объектов, на которые отсутствуют указания в законе, в уголовно-процессуальной форме предъявления для опознания. Правильнее проводить идентификацию этих объектов в ходе проведения следственного эксперимента или проверки показаний на месте, либо в условиях непроцессуального опознания

В зависимости от того, предъявляется сам объект или его изображение (фотографии, видеозапись, рисунок, электронное изображение и

${ }^{6}$ Напоминаем, что примеры этих и других документов можно скачать на сайте labatr.bsu. $\mathrm{ru}$, ссылка на данное руководство, электронное приложение № 10 . 
т.п.), принято различать опознание непосредственное и опосредованное. Бывает так, что целью опознания является не отождествление объекта, а определение его групповой принадлежности.

Предъявлять для опознания можно только те объекты, которые ранее опознающий воспринимал визуально, а не иным способом (признаки слухового, осязательного, обонятельного, вкусового способов могут учитываться лишь в качестве дополнительных в том случае, когда наряду с визуальным опознающий ранее воспринимал объект еще и иным способом).

Ниже предложены краткие рекомендации по проведению данного следственного действия с участием помощника, практиканта. Подробные тактико-криминалистические рекомендации, но только для следователей, имеются во многих учебных, практических и научных изданиях. Напомним основные требования закона, а также хорошо известные тактико-криминалистические рекомендации по предъявлению для опознания Отметим то, что можно и нужно делегировать помощнику, практиканту:

1. Предварительный допрос опознающего для выяснения признаков объекта.

С учетом правил, изложенных в гл. 9, следователь может поручить составление проекта протокола своему помощнику или практиканту. В протоколе особенно важно уточнить не только обстоятельства, при которых допрашиваемый воспринимал объект, но и характерные признаки последнего (ч. 2 ст. 193 УПК РФ).

Если опознающим является потерпевший или свидетель, их необходимо предварительно предупредить об ответственности за отказ и уклонение от дачи показаний и дачу заведомо ложных показаний. Наводящие вопросы запрешаются. Если опознающим является подозреваемый, обвиняемый, им необходимо предварительно под роспись разъяснить их права.

2. Недопустимость предварительного ознакомления опознающего с предбявляемым объектом.

Следователь должен предупредить об этом своего помощника, практиканта. К сожалению, в практике распространены случаи, когда до проведения следственного действия опознающий случайно или намеренно допускается до объекта опознания (видит опознаваемое лицо, фотографию и т.п.). Бывают и провокации, например, когда недобросовестный адвокат сам организует встречу своего подзащитного (опознаваемого) с потерпевшим (опознающим), а затем требует признания соответствующих доказательств недопустимыми. Умелыми организационными действиями помошник (практикант) может предотвратить такое развитие событий, тем самым обеспечить объективность резуль- татов опознания, избежать возможных ошибок или умышленных искажений действительности.

3. Предъявление объекта среди других, по возможности сходных (ч.ч. 4-6 cm. 193 УПК РФ)

Следователь может поручить своему помощнику или практиканту подыскать однородные, схожие по внешнему виду объекты, например, двух людей, схожих с опознаваемым, две фотографии, два предмета. Если опознающий на допросе не смог достаточно определенно описать соответствующие признаки, помощнику можно поручить найти большее число объектов. Данное условие не распространяется на случаи опознания трупа (ч. 4 ст. 193 УПК РФ), а также уникальных произведений искусства, антиквариата (картины, иконы, ювелирные изделия и т.п.).

Одним из правил проведения данного следственного действия является то, что опознаваемому человеку до предъявления для опознания необходимо предложить занять по своему усмотрению любое место среди предъявляемых лиц. Место же предъявляемого для опознания предмета определяется самим следователем.

При наличии нескольких объектов, которые могут быть предъявлены одному и тому же опознающему, они предъявляются по отдельности, но каждый среди не менее двух объектов.

4. Конкретизация признаков, по которым объект опознан

Поскольку закон требует, чтобы опознающий объяснил, по каким приметам или особенностям он опознал данное лицо или предмет (ч. 7 ст. 193 УПК РФ), нельзя удовлетворяться одним лишь утвердительным ответом опознающего на вопрос, узнает ли он какой-либо из предъявленных объектов. Необходимо здесь же, в присутствии понятых, уточнить, какие именно индивидуальные приметы, особенности объекта дали уверенность в том, что он идентифицирован.

Эти вопросы следователь должен задать сам и получить ответы в присутствии всех участников следственного действия. А вот законспектировать эти и другие его результаты можно поручить помощнику (практиканту). Далее он же может составить на компьютере проект протокола (см. гл. 9), в который заносятся показания опознающего по возможности дословно.

\section{5. Подбор и приглашение участников}

Как известно, субъектами опознания - опознающими, могут быть лица, допрошенные в качестве свидетелей, потерпевших, подозреваемых, обвиняемых, если они запомнили признаки объекта и выражают готовность его опознать. В этом следственном действии, помимо следователя, должны принимать участие опознающий, все лица, ко- 
торые ему предъявляются (если это опознание людей), и понятые. В случаях, предусмотренных законом, в мероприятии участвуют: адвокат-защитник, переводчик или лицо, понимающее азбуку глухонемых, врач, если опознающий болен, педагог, если опознающий моложе 14 лет. При необходимости следователь приглашает специалиста, например, для фотографирования, видеозаписи. В качестве такового, как уже отмечалось в гл. 5, может быть приглашен общественный помощник или практикант ${ }^{77}$.

В первую очередь, после определения следователем круга участников следственного действия, общественному помощнику может быть поручен подбор и обеспечение явки понятых и опознаваемых лиц, подбор иных объектов опознания. Ему же можно поручить приглашение и размещение остальных участников, обустройство места проведения мероприятия и т.п.

6. О некоторых мерах безопасности участников судопроизводства

Как известно, опознание чаще всего проводится в условиях, когда опознаваемые и опознающий видят друг друга. Вместе с тем положения ч. 3 ст. 11 , ч. 9 ст. 166 и ч. 8 ст. 193 УПК РФ допускают, что в случае необходимости в отношении участников процесса, в том числе в рамках предъявления для опознания, могут быть применены меры безопасности. Для этого необходимо создать условия, исключающие визуальное наблюдение опознающего опознаваемым. Закон уточняет лишь одно правило: в этом случае понятые должны находиться в месте нахождения опознающего (ч. 8 ст. 193 УК РФ).

Для этого нужно заранее позаботиться о специально оборудованном помешении. Оно должно иметь перегородку из стекла с зеркальным напылением, через которое видно только с одной стороны. Во многих горрайотделах такие помещения подготовлены специально. Если в вашем подразделении, уважаемые коллеги, таких условий нет, то стоит заранее договориться с коллегами из других районов. Если и этот вариант исключается, попробуйте узнать, нет ли в других, неправоохранительных, органах подобные помещения. Если нет, придется оборудовать обычное помещение телесистемой, чтобы обеспечить опознание по изображению на телеэкране. То есть в одной комнате (части комнаты) размещается видеокамера, в другой - монитор. В таком случае следователь, опознающий и понятые находятся в комнате, где стоит

${ }_{77}$ Кроме прочего, не следует забывать и об охране в случае, например, опознания задержанного или арестованного. Охранников надо проинструктировать, чтобы их действия не указывали на подозреваемого, обвиняемого. Иначе их неосторожные действия могут привести к недопустимости доказательства. - Прим. отв. ред. монитор $^{78}$. Где размещаются иные участники, в том числе защитник, переводчик и другие - решает следователь, выполняет - его помощник.

7. Тому же помощнику или практиканту мы поручаем подготовку, размещение и проверку технических средств: фото- и видеотехники, необходимой для:

а) фиксации хода и результатов данного следственного действия;

б) запечатления опознаваемых лиц (по грудь и в полный рост) и иных объектов.

Напомним, что профессионального специалиста (как правило, из ЭКО горрайотдела милиции) не всегда допросишься, дождешься, а если и повезет, то ненадолго. Да и по поводу слишком частых вызовов следователя вряд ли поблагодарят. Кроме того, за отснятыми фото-, видеоматериалами ходить приходится не раз... Выход известен - учите своего помощника!

И не забудьте вновь ему провести небольшой «ликбез». Так, фотосъемку в помещении лучше выполнять с дополнительными источниками освещения, так как фотовспышка иногда искажает внешности опознаваемых. На видеозаписи должны найти отражение все условия и последовательность опознания, поведение его участников. Для этого используются общие планы, обзорная и детальная съемка (для демонстрации особенностей внешности). Если лицо опознается по динамическим признакам есть смысл поручить помощнику применение отдельно звуко- или опять же видеозаписи

Применение видеозаписи чаще требуется в тех ситуациях, когда опознание производится по походке, жестикуляции, мимике, другим функциональным признакам. Так как данное следственное действие, чаще всего, можно провести лишь один раз, предварительная подготовка к видеозаписи очень важна. Следует заранее обозначить наиболее подходящие точки съемки и операторские приемы. Вначале делают обзорную съемку опознаваемых объектов с «наездом» на каждый. Затем снимаются все действия, которые проводятся по указанию следователя. Особенно важно запечатлеть реакции опознающего и его заявления. Далее в видеозаписи должны присутствовать те признаки объекта, по которым произошло опознание (если оно произошло). Фотоснимки, видео- и аудиоматериалы прилагаются к протоколу.

8. Следует помнить и о недопустимости повторного опознания объекта тем же опознающим по тем же признакам.

${ }^{78}$ Практике известны многочисленные примеры, когда по так называемым «проблемным» делам, где идет активное противодействие расследованию, следователям приходится пригла. давать повод стороне защиты обжаловать допустимость доказательств в связи с незаконным воздействием на одного из участников следственного действия. - Прим. отв. редактора. 


\section{Особенности предъявления для опознания отдельных видов объектов}

При предъявлении для опознания человека после того как следователь разъяснит присутствующим (исключая опознающего) их права и обязанности, опознаваемому предлагается занять любое место среди предъявляемых лиц. Разумеется, так, чтобы об этом не знал опознающий. Затем последний приглашается в помещение, ему тоже разъясняются его права и обязанности. Для более полного восприятия признаков внешности следовать предлагает всем опознаваемым лицам встать, сесть, повернуться, пройтись по комнате. При этом помощник (практикант) может вести как фото-, так и видеосъемку.

Затем следователь спрашивает опознающего, опознал ли он кого-то, и если да, то по каким именно признакам. Помощник может конспектировать заявление опознающего, которое затем может быть включено в протокол предъявления для опознания, например: «... опознаю по карим глазам, крупному носу с горбинкой, подбородку с ямочкой...»

После завершения рабочей стадии опознания опознаваемые лица еще раз фотографируются, как правило, сидя и стоя. Нужно запечатлеть расположение опознаваемых в момент опознания, а также отдельно опознанного по правилам сигналетической (опознавательной) фотосъемки. Не стоит забывать, что в протоколе отражается и сам факт фотографирования (видеозаписи), и условия съемки, и характеристики фотоаппаратуры, носителей.

Опознание по голосу, устной речи или походке. Следует иметь в виду, что ст. 193 УПК РФ допускает лишь визуальный способ восприятия предъявляемого объекта, сформированного у опознающего также визуальным, а не слуховым способом. Процессуальная идентификация человека по признакам образа его голоса и речи в следственной тактике может рассматриваться применительно к следственному эксперименту, проводимому для проверки возможности узнавания. Опознавать по голосу можно лишь при условии, если опознающему известно, кому именно принадлежит этот голос, то есть когда имеет возможность увязать предъявляемый голос с лицом, которого он ранее воспринимал не только слуховым, но и визуальным способом. В памяти опознающего находятся как минимум два образа опознаваемого: визуальный и звуковой.

Если опознающий запомнил голос или походку опознаваемого, производится опознание по этим функциональным признакам. При допросе опознающего необходимо выяснить следующие обстоятельства:

- о продолжительности и условиях слухового восприятия допрашиваемым голоса и речи человека;
- о характере, содержании, особенностях воспринятой и запомнившейся звуко-речевой информации;

- о физическом и психическом состоянии на тот момент допрашиваемого, его слуховых возможностях;

- о степени точности и полноты запомнившихся ему признаков воспринятых голоса и речи;

- о том, слышал ли он ранее этот голос, знаком или не знаком с человеком, которого он в данный момент воспринимал слуховым способом, сможет ли узнать голос или человека, которому он принадлежит.

При допросе опознающего необходимо выяснить не только содержательную составляющую устно-речевой информации, воспринятой им в условиях слухового восприятия лица, о котором даны показания, но и эмоциональную и акустическую составляющие. Опознание по голосу проводится по признакам, характеризующим его силу, диапазон, высоту, тембр и т.п., а также по индивидуальным особенностям речи: дефекты заикания, шепелявости, картавости, частые междометия и др.

Следователю при помощи помощника нужно подобрать помещение, состоящее из двух смежных комнат, или чтобы в комнате была соответствующая перегородка. Опознающий, следователь и понятые помещаются в одной, а опознаваемые - в другой комнате, где последние под руководством помощника следователя будут произносить заранее оговоренные фразы. Помощнику не лишним будет поручить провести репетицию их произнесения. Опознающий не должен видеть, но должен хорошо слышать опознаваемых. Следователь и опознающий в присутствии понятых слушают их, затем опознающий заявляет, узнал ли он кого-либо. Затем все участники собираются вместе. Здесь следователь объявляет, кто и в какой последовательности и что произносил, кого именно узнал опознающий.

Опознание по устной речи может быть произведено и с использованием фонограмм, если нет возможности провести мероприятие «очно». Помощнику можно поручить подготовку следующих материалов: специальная фонограмма с устной речью опознаваемого, свободные образцы его же речи (записанные не в связи с расследуемым делом). Для записи специальной фонограммы общественный помощник готовит текст, который будут произносить опознаваемый и двое других лиц со сходными голосами.

Опознание по походке рекомендуется проводить в том же месте, в котором событие воспринимал опознающий, по возможности в тех же условиях. Важное значение имеет проведение опознания в таких же временных, сезонных, погодно-климатических условиях, что существовали в момент 
реального, исследуемого по делу события. Следует также учитывать, что темп передвижения (медленная, быстрая ходьба, средний темп, бег с определенной скоростью) оказывает влияние на двигательные особенности человека. Опознаваемые не должны резко отличаться друг от друга по росту, телосложению, одежде и т.п. Опознающий вместе со следователем и понятыми располагается на исходном месте. Опознаваемые несколько раз проходят по известному ему маршруту. С этой группой может работать помощник, если он, конечно, не занят в видео- и фотосъемке. Затем опознающий называет место, которое занимал опознанный.

При предбявлении для опознания трупа для установления его личности часто лица, могущие опознать тело, не известны. Следователь обращается к местным жителям с просьбой явиться для опознания Можно поручить помощнику предварительный допрос каждого опознающего. Такой допрос необходим, в том числе в таких случаях: вопервых, если явившийся к следователю гражданин заявляет, что может опознать покойного; во-вторых, если имеются некоторые данные о его личности, но следователь желает их уточнить у тех, кто заведомо знает опознаваемого

В ходе предварительного допроса выясняются не только признаки внешности. Уточняются особые приметы, скрытые одеждой (шрамы, родимые пятна и т.п.). Выясняется как мог быть одет покойный, какие предметы, украшения могли быть при нем. Далее производится собственно опознание трупа, которое следователю лучше провести самому. Опознание можно провести и по фотоснимкам, выполненным по правилам сигналетической (опознавательной) съемки. Ее можно поручить помощнику, однако только в случае его психологической готовности к такой работе. Фотографируется голова трупа в анфас, оба профиля и 3/4 поворота. Отдельно запечатлеваются части тела с особыми приметами. Опытные специалисты рекомендуют делать черно-белые снимки, так как на цветных раны, трупные пятна и т.п. могут сильно затруднить опознание. Неопознанный труп обязательно дактилоскопируют для проверки по учетам. Подробно описываются все обнаруженные с ним вещи и предметы. Иногда практикуется снятие с лица трупа гипсовой маски. И такого рода поручения можно дать помощнику, но при условии его психологической устойчивости.

Предъявление для опознания предметов и документов проводится по общим правилам, изложенным выше. В ходе предварительного допроса у опознающего выясняются общие и частные признаки предмета: его назначение, примерные размеры, форма, цвет, материал, отличительные особенности. Предмет предъявляется с двумя сходны- ми, которые предварительно может подобрать помощник. При этом ему следует поручить для каждого приготовить бирку с порядковыми номерами и разложить предметы с бирками в удобном для опознания и фиксации месте.

Как мы уже отмечали, на практике с легкой руки некоторых ученых перечень объектов, предъявляемых для опознания, был несколько расширен. Не поддерживая такого расширения, все же остановимся на ряде данных ими рекомендаций.

Опознание документов проводится по общим правилам и к нему предъявляются те же требования, что и к опознанию предметов.

Опознания животных проводится, как правило, по делам об их хищениях, для установления их владельца. Предварительный допрос можно поручить помощнику. Ему необходимо будет выяснить породу животного, его масть, пол, размеры, возраст, упитанность, кличку, особые приметы, клейма, травмы, окрас и др. Животное предъявляется среди двух-трех сходных, подобранных помощником. Обращается внимание на реакции животного на голос, ласку, какие-то движения опознаюего.

Опознания участка местности и строений (помещений) нужно тогда, когда допрашиваемый запомнил их и может опознать. В таких случаях следователю всегда важно убедиться в том, что допрашиваемый там действительно был. Предъявление производится с соблюдением общих правил. Например, необходимо опознать однокомнатную квартиру. Для этого помощнику нужно поручить подобрать еще две однотипные квартиры и договориться с хозяевами об их посещении участниками следственного действия. Обстановку каждой квартиры осматривают и сравнивают с предварительными показаниями. С учетом общих и частных признаков делается вывод о тождестве или его отсутствии.

Фиксация хода и результатов предъявления для опознания, оценка его результатов. Как и в других следственных действиях, основной способ - протоколирование. Протокол состоит из трех частей: вводной, описательной, заключительной, содержание которых регламентировано ст.ст. 166 и 167 УПК РФ. Помощник может заранее подготовить проект документа на компьютере, а затем по указанию следователя вносить в него все дополнения и изменения. С учетом специфики данного следственного действия, зачастую выездного характера его проведения, проект протокола удобнее готовить или на ноутбуке, или все же вручную, на бланке. При этом фрагменты описательно части, как правило, помощнику лучше готовить на черновике, а затем уже по указанию следователя переносить в протокол. 


\section{Глава 12}

\section{ОСОБЕННОСТИ ПРОВЕРКИ ПОКАЗАНИЙ НА МЕСТЕ}

Проверка показаний на месте является одним из наиболее сложных следственных действий. В то же время оно весьма ценно, поскольку предоставляет следователю определенную свободу в реализации задуманных тактических операций, широкие возможности для проверки достоверности показаний подозреваемого, обвиняемого, потерпевшего, свидетеля. С помощью этого следственного действия окончательно фиксируются, процессуально закрепляются ранее полученные показания, в случае, если будет установлена их достоверность.

Несмотря на всю его сложность, и это следственное действие может и должно производиться с помощью общественного помощника и практикантов. Общие подходы к использованию их труда см. в главе 11.

С точки зрения криминалистической тактики выделяют следующие основные разновидности проверки показаний на месте в зависимости от поставленных целей:

1) отыскание с помощью лица, показания которого проверяются, еще не обнаруженных следов события, предметов, которые должны иметься на местности (если показания соответствуют действительности);

2) обнаружение на местности по указанию лица объектов, наличие которых делает событие возможным или невозможным (наличие лаза, укрытий, о которых сообщило в своих показаниях лицо, и т.п.);

3) установление реально существующих деталей обстановки, свидетельствующих об осведомленности лица о событии (правильное описание расположения мебели в квартире, куда проникли похитители), а также выявление изменений, которые произошли в обстановке, по сравнению с той, которая существовала в момент события;

4) указание на известные лицу детали местности, которые в момент проверки отсутствовали, однако наличие их в прошлом получило отражение в материалах дела (указание на места захоронения трупов, ранее обнаруженных при осмотре места происшествия, и т.п.)

5) определение маршрута движения, порознь указанного участниками события ${ }^{79}$

79 Комментарий к Уголовно-процессуальному кодексу Российской Федерации / Под ред. И.Л. Петрухина. М.: «Проспект», 2008. С. 164.
В соответствии со ст. 194 УПК РФ проверка показаний проводится с участием подозреваемого, обвиняемого, потерпевшего и свидетеля. Ее целью является установление новых обстоятельств, имеющих значение для уголовного дела. В примененной законодателем формулировке кроется своеобразный «подвох»: следователем (дознавателем) в качестве цели проведения данного следственного действия должно быть определено какие-либо новое обстоятельство, ранее не известное. Хотя проблем с этим в практике обычно не возникает, тем не менее считаем целесообразным во вводной части протокола указывать, что следственное действие проводится не только лишь с целью проверки показаний лица, но и для установления новых обстоятельств, имеющих значение для дела.

Порочной практикой следует признать использование следователем в протоколе проверки показаний на месте ранее набранного на компьютере текста показаний проверяемого лица, например, изложенных в протоколе допроса подозреваемого или обвиняемого. Полное копирование текста ставит под сомнение достоверность показаний, хотя бы по той простой причине, что повторить их слово в слово фактически невозможно.

Проверка показаний на месте зачастую связана с привлечением к участию в ней целой группы лиц: проверяемого, его защитника (адвоката, а иной раз и нескольких), понятых, статистов, эксперта, специалиста, водителя, конвойных. Разумеется, добиться от группы людей абсолютно точного исполнения распоряжений следователя затруднительно. Ведь предполагается, что он должен одновременно и вести протокол, составлять схемы, и руководить следственным действием, давать указания его участникам, следить за их исполнением, а также за полнотой проверки, соблюдением всех требований закона и т.д.

Поэтому именно здесь следователю может особенно понадобиться помошь обшественного помошника, практиканта. Им следует постоянно ставить себя на место следователя и, в частности, стараться заметить возможные неточности, неполноту проверки, обрашая на это внимание куратора. Неплохо было бы вести свой вариант протокола, который впоследствии можно использовать как черновик, проект окончательного документа. Ведь реальный протокол проверки показаний в окончательном виде составляется, как правило, по его окончании. И если следователь что-то упустит, это можно будет восполнить, обращаясь к проекту протокола, составленного общественным помощником, практикантом.

Ввиду особой сложности рассматриваемого следственного действия рекомендуется тщательная подготовка к его проведению. При этом следователь должен четко уяснить для себя, какие именно сложности, противоречия, спорные моменты, свидетельствующие о недостовер- 
ности или неполноте показаний проверяемого лица, ему необходимо установить или проверить. Рекомендуем составление детального плана проверки показаний, который позволил бы избежать невосполнимых пробелов. К примеру, следователь может установить личность потерпевшего, показания которого проверяются, и забыть предупредить его об уголовной ответственности за отказ от дачи показаний или дачу заведомо ложных показаний. Как результат - протокол следственного действия признается судом недопустимым доказательством.

От следователя требуется спокойствие и выдержка, чтобы под объективом видеокамеры и пристальным вниманием (зачастую не очень доброжелательным) участников следственного действия, не упустить важные детали проверки показаний. Заглядывая в план следственного действия, которым, кстати, на начальной стадии проверки может являться и вводная часть протокола, составляемого в соответствии с требованиями ст. 166, 194 УПК РФ, следователь ничего не забудет.

На подготовительном этапе рекомендуется убедиться в наличии исправной видео-, аудиотехники, полной зарядке аккумуляторов, наличии свободного места на жестком диске (флеш-карте или оптическом носителе) видеокамеры, дабы потом не прерывать следственное действие для поиска источника электропитания или магазина для покупки CD-R диска.

И вновь в этом деле следователю может пригодиться общественный помощник, практикант, который вполне может справиться с подготовкой и эксплуатацией техники. В случае использования стажера в качестве специалиста, осуществляющего видеозапись или фотографирование, необходимо его тщательно проинструктировать в порядке, описанном в 7.2.

Также в случае привлечения к участию в следственном действии эксперта-криминалиста (судебно-медицинского эксперта) рекомендуется заранее побеседовать с ним, но, разумеется, не для того, чтобы настроить его на дачу нужных только следователю пояснений, а для того, чтобы убедиться в том, что эксперт, по крайней мере, имеет требуемую квалификацию и в курсе того, на какую тему ему могут быть заданы вопросы. Ведь зачастую ему для этого требуется использование специальной литературы или технических средств. К чести экспертов-криминалистов при органах внутренних дел они обычно хорошо подготовлены и носят все необходимое с собой. Но ведь может возникнуть такая ситуация, что понадобится, к примеру, металлоискатель - вещь громоздкая, о наличии которой в нужный момент следует позаботиться заранее.

Немаловажный вопрос - привлечение к участию в проверке показаний понятых, которые смогли бы потом подробно и беспристрастно рассказать об увиденном и услышанном в ходе проверки показаний. Ведь очень часто работа следователя оказывается совершенно никчемной только из-за «дефекта с понятым», например, из-за ложности указанного им адреса места жительства. Вновь напомним о недопустимости использования понятых из числа общественных помощников и практикантов (см. гл. 5), а также водителей, секретарей и уборщиц следственных подразделений. Судебная практика по данному вопросу сформировалась давно - такие понятые-свидетели признаются заинтересованными лицами. Последствия очевидны.

При проверках показаний, проводимых длительное время, часто возникают комичные ситуации: понятые устают и потихоньку ускользают из поля зрения следователя, а затем просто удаляются. Так, в практике следственного управления МВД Республики Бурятия протокол проверки показаний подозреваемого был признан недопустимым доказательством, поскольку после ухода одного из понятых, следователь, не заметив этого, продолжал проверку. Закончив и убедившись в отсутствии понятого, он пошел на нарушение закона, нашел того по месту жительства и получил его подписи в протоколе только через несколько месяцев. Протокол проверки был исключен из объема доказательств в виду нарушений требований ст.ст. 166, 170 и 194 УПК РФ, в адрес начальника следственного подразделения судом было внесено частное постановление.

Конвойное сопровождение находящегося под стражей лица осуществляется специализированными подразделениями органов внутренних дел. Туда заранее нужно направить письменное требование о необходимости сопровождение арестованного в ходе следственного действия. Требование направляется в следственный изолятор (СИЗО). Практикант может доставить документ сотрудникам конвойного подразделения и в СИЗО, а также взять на себя другие вопросы организации конвоя

Между тем в практике часто подозреваемого, задержанного в порядке ст. 91 УПК РФ, сопровождают оперативные работники. Применительно к таким случаям следователю необходимо исключить возможные в дальнейшем обвинения в оказании незаконного давления с их стороны на подозреваемого. В дальнейшем в суде это может поставить под удар допустимость протокола проверки показаний. С этой целью можно периодически в ходе проверки показаний с использованием видеозаписи задавать проверяемому лицу вопросы типа: добровольно ли оно дает показания (указывает на место преступления и т.п.); не оказывалось ли на него незаконное давление со стороны участвующих лиц. Ответ следует фиксировать на видео. 
Не лишним будет также после окончания проверки допросить проверяемое лицо (в необходимых случаях с участием адвоката-защитника), а также понятых по обстоятельствам проведения проверки, фиксируя вкратце не только содержание следственного действия и полученные результаты, но и соблюдение различных процессуальных формальностей. В целях предупреждения возможного в будущем противодействия целесообразно задать примерно следующие вопросы:

1. Добровольно ли Вы согласились на участие в проверке показаний?

2. Оказывалось ли на Вас какое-либо давление со стороны оперативных работников или следователя как до, так и во время проверки показаний и после нее?

3. Давали ли Вы добровольно и свободно показания на допросах, предшествующих проведению проверки показаний?

4. Давалисьли Вам какие-либо подсказки со стороны следователя или иных участников следственного действия в ходе проверки показаний?

5. Каково было Ваше самочувствие в ходе проверки показаний на месте? Повлияло ли Ваше состояние здоровья, психоэмоциональное состояние момент проверки на правдивость и полноту данных Вами показаний?

6. По Вашему мнению, результаты проверки подтверждают правдивость ранее данных Вами показаний?

7. С Вашей точки зрения, были ли допущены какие-либо нарушения закона в ходе проведения проверки?

8. Вами прочтен протокол проверки показаний, просмотрена видеозапись. Все ли в протоколе отражено верно, имелись ли у Вас какие-либо замечания, которые следователь не внес в протокол?

9. Имеются ли обстоятельства, которые вынудили Вас дать показания помимо Вашей воли?

При подобном подходе противодействующим лицам будет довольно сложно в последующем поставить под сомнение достоверность показаний, полученных в ходе проверки.

Поскольку такого рода допросы носят как бы вспомогательный, «страховочный» характер, к его проведению можно привлекать общественного помощника, практиканта, не забывая про рекомендации, изложенные в гл. 9.

Итак, следователь должен на момент начала проверки:

- иметь четкое представление о том, какие именно показания лица он будет проверять;

- что он предполагает узнать (найти) нового, необходимого для дела;

- иметь в своем распоряжении необходимые и безотказные технические средства, включая автомобиль или несколько автомобилей;
- обеспечить присутствие надлежащих, а не «дефектных» понятых

- обеспечить конвой в случае необходимости проверки показаний находящегося под стражей подозреваемого (обвиняемого);

- заранее направить уведомления о необходимости прибыть в назначенное время адвокату-защитнику. В качестве статистов можно привлечь тех же практикантов (см. например, правила из гл. 11) или иных лиц.

Как уже отмечалось, в ходе проведения проверки рекомендуется использовать не только видео-, но и фотосъемку. К примеру, в практике расследования дел об убийствах зачастую существенное значение имеет положение рук подозреваемого в момент совершения выстрела, способ удержания огнестрельного или холодного оружия в момент совершения преступления и т.п. Полученные в ходе проверки показаний сведения могут быть использованы для назначения медико-криминалистической экспертизы, которую следователи часто называют ситуационной. Ее целью является проверка показаний подозреваемого (или иного лица), к примеру, по поводу возможности причинение потерпевшему телесных повреждений при описываемых подозреваемым обстоятельствах. В подобных ситуациях фотоснимки позволят эксперту установить точное направление ствола огнестрельного оружия, сравнить его с расположением раневых каналов в теле потерпевшего и дать заключение о возможности производства выстрела при таких обстоятельствах. Следователь, в свою очередь, сможет сделать для себя вывод о том, насколько правдивы показания проверяемого лица.

К примеру, в следственно-судебной практике Республики Бурятия имел место случай, когда следователь в ходе проведения проверки показаний на месте не уделила должного внимания расположению обреза в руках подозреваемого в момент выстрела, не зафиксировала данное обстоятельство с помощью фото- и видеосъемки, не допросила подозреваемого детально по данному поводу, ограничившись скопированной из одного протокола в другой фразой: «Он (имеется в виду потерпевший) открыл дверь и я выстрелил в него». В последующем подсудимый заявил, что у него повреждены сухожилия на кисти правой руки, и когда потерпевший открыл дверь, он, пытаясь увернуться от удара дверью, не смог удержать падающий обрез правой рукой и непроизвольно нажал на курок. Учитывая, что совокупность изученных доказательств свидетельствовала об умышленном характере действий подсудимого, судом с целью проверки его показаний были проведены следующие мероприятия:

1) подсудимый в зале суда продемонстрировал расположение обреза, своих рук, двери и потерпевшего в момент выстрела. При этом все его движения фиксировались на фото; 
2) судом была назначена дополнительная судебно-баллистическая экспертиза с целью установления соответствия усилия на спусковом крючке обреза требованиям ГОСТ;

3) назначена комплексная судебная медико-криминалистическая экспертиза.

На проведение данных мероприятий потребовалось два месяца судебного разбирательства. В результате заведомо ложные показания подсудимого были опровергнуты. Он был осужден по ч. 1 ст. 105 УК РФ. Но ведь вся эта объемная и затратная работа была проведена из-за некачественной, неполно проведенной следователем проверки показаний. Да и не всякий судья предпримет такие усилия.

Фотоснимки в ходе проверки показаний может сделать стажер, следуя при этом указаниям следователя. Стажера для этого, разумеется, необходимо заранее проинструктировать и проверить его навыки фотосъемки. Чтобы после проведения проверки не оказалось, что следователь не выполнил необходимые для производства экспертиз замеры, не сфотографировал или не зафиксировал на видео, предположим, направление ствола оружия, взаиморасположение статиста в роли потерпевшего и подозреваемого лица, считаем целесообразным заранее получить консультацию у эксперта. Не следует пренебрегать и специальными справочниками для следователей по вопросам назначения экспертиз ${ }^{80}$.

Тшательно подготовившись по предложенному алгоритму, можно приступить к проведению проверки показаний. А начинать следственное действие следует в служебном помещении следователя, поскольку проверяемое лицо само должно указать, куда следует выехать группе для проверки его показаний (ч. 4 ст. 194 УПК РФ). При подготовке вводной части протокола следователь должен разъяснить всем участникам следственного действия их права и обязанности, при необходимости предупредить об уголовной ответственности по ст.ст. 307 и 308 УК РФ, убедиться в том, что все расписались в соответствующих графах протокола, разъяснить порядок производства проверки. Установление личности участвующих лиц, разъяснение им прав и обязанностей фиксируется на видео. Перерывы в видеозаписи специально оговариваются следователем.

Хотя проверка показаний подозреваемого или обвиняемого - следственное действие по своей сути добровольное, считаем необходимым в

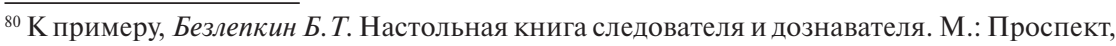
2008. начале проверки одновременно с разъяснением прав, предусмотренных ст.ст. 46 и 47 УПК РФ, отдельно разъяснить ему положения ст. 51 Конституции РФ. Это устранит всякие сомнения в действительном намерении лица дать показания и исключит последующие споры в суде. Зачем ставить судью перед необходимостью решать вопрос о допустимости протокола проверки показаний из-за такой мелочи? А ведь подсудимый с этой целью может заявить, что показания давал под принуждением, положения ст. 51 Конституции РФ на момент проверки уже не помнил, все статьи законов для него звучат одинаково и т.п.

В ходе проверки показаний требуется неукоснительное соблюдение правила, предусмотренного ч. 2 ст. 194 УПК РФ - какое-либо постороннее вмешательство в ход проверки и наводящие вопросы недопустимы. При проведении проверок по значительному количеству эпизодов (к примеру, краж автотранспорта) сложно выбрать оптимальный маршрут следования группы и не забыть при этом одно или несколько мест. Предлагаем один из вариантов решения данной проблемы: проверяемое лицо после предварительного допроса получает копию протокола своего допроса. В начале проверки показаний проверяемый поясняет на соответствующий вопрос следователя, что поскольку требуется указать значительное количество мест и сформировать оптимальный путь движения, он будет давать показания и указывать места в соответствии с тем порядком, который был им изложен ранее на допросе от такого-то числа. Такой комментарий устранит всякие сомнения в добровольности и свободе участия лица в проверке показаний.

В ходе проверки лицо, показания которого проверяются, идет впереди следователя и всех остальных участников следственного действия и уточняет, а также дополняет свои ранее данные показания с учетом обстановки места и расположения находящихся на нем объектов. Допрашиваемый может демонстрировать, как именно, в какой последовательности происходили описанные им ранее события и т.д. Необходимо подбирать удачный ракурс для фото- и видеосъемки, чтобы в кадре были все участники следственного действия или, по крайней мере, понятые и проверяемое лицо. Располагать понятых на месте следует таким образом, чтобы они видели каждое движение проверяемого лица, отчетливо слышали его показания. Следить за расположением понятых можно поручить практиканту. Это задача не представляет особой сложности, и не будет отвлекать следователя.

Действия следователя, его диалог с лицом, чьи показания проверяются, занимаемые места при передвижении должны выразительно 
подчеркивать, что инициатива в выборе направления следования, узнавании объектов, демонстрации действий принадлежит дающему показания. Немаловажное значение имеет порядок передвижения конвоя. Непосредственно на месте проверки следует снимать с подозреваемого (обвиняемого) наручники.

В случае, если проверка показаний связана с выездом к отдаленному месту, сопровождается не только поездкой на автомобиле, но и движением пешком, к примеру, через лесной массив к месту захоронения трупа, следователю необходимо фиксировать все передвижения группы на черновик схемы. В нем следует отражать основные ориентиры, направление движения по компасу, перепады высот. При наличии навыков выполнить эту работу может и общественный помощник, практикант. Также они могут зафиксировать основные ориентиры на фото, используя обзорную фотосъемку.

Обнаруженные в ходе проверки показаний на месте следы, предметы и документы подлежат изъятию с соблюдением тех же требований, что предусмотрены для осмотра места происшествия (см., например, гл. 7). Следователь, его общественный помощник, практикант должны иметь при себе необходимый запас пакетов или иного упаковочного материала, скотч, отрезки бумаги с оттисками печати следственного подразделения, веревку и другие необходимые предметы (подробнее см. гл. 3).

Как правило, только после проведения проверки и возвращения группы в кабинет следователя составляется протокол, схемы и при возможности фототаблицы ${ }^{81}$. Данные материалы, а также видеозапись предъявляются участникам следственного действия для ознакомления, после чего протокол подписывается. Следователь выясняет, имеются ли у кого-либо замечания к протоколу и к самому процессу производства следственного действия.

Неоценимую помощь в ознакомлении с материалами, в том числе с видеозаписью, в быстром и качественном составлении протокола может оказать общественный помощник. Он вполне может помочь в наборе текста протокола или же, наоборот, продиктовать следователю его и свои записи, оформить для него схемы, распечатать на принтере фотографии и т.п. В случае, если в ходе проверки следователь забыл что-то выяснить у проверяемого лица, а также если возникли дополнительные вопросы, их можно задать как в рамках дополнения к протоколу про-

${ }^{81}$ Напоминаем, что примеры этих и других документов можно скачать на сайте labatr.bsu. $\mathrm{ru}$, ссылка на данное руководство, электронное приложение № 11. верки показаний, так и в рамках отдельного допроса, с производством которого желательно не затягивать.

Результаты применения технических средств (фототаблицы, схемы и т.п.) прилагаются к протоколу. Весьма распространены в судебной практике случаи, когда аудио- и видеозаписи исключаются из объема доказательств в виду их низкого качества или проблем с воспроизведением. Чтобы избежать данных проблем, желательно позаботиться о следующих моментах:

1) использовать, как уже отмечалось, не одно техническое средство, а их комплекс, то есть, например, и видео- (и фотосъемку);

2) позаботиться о качественных, желательно новых носителях информации: видеокассетах, дисках, флеш-картах; обеспечить их надлежащее хранение вплоть до направления дела в суд;

3) стремиться использовать цифровые виды записи и сохранять их в стандартных и широко распространенных форматах (*.mpeg, *.mpg, *.avi, *.mp3 и т.д.);

4) заранее опробовать качество записи и при необходимости скорректировать настройки аппаратуры.

Все это, как видим, можно и нужно доверить общественному помощнику, практиканту. 
Глава 13

\section{ОСОБЕННОСТИ ОСМОТРА ВЕЩЕСТВЕННЫХ ДОКАЗАТЕЛЬСТВ}

По уже рассмотренным и вполне объективным причинам следователь не всегда сразу доверяет общественным помощникам и практикантам так называемую «живую работу», то есть содействие в производстве следственных действий с участием свидетелей, потерпевших, а тем более лиц, подлежаших привлечению к уголовной ответственности. Следователю нужно время для того, чтобы убедиться в добросовестности своего помощника ${ }^{82}$. В то же время правоприменитель почти всегда уже в самом начале совместной работы может поручить молодежи выполнение такой работы, результаты которой можно будет перепроверить и при необходимости внести корректировки, после чего подписать протокол или постановление. Прежде всего речь идет о составлении проектов некоторых процессуальных документов ${ }^{83}$ : постановления об отказе в возбуждении уголовного дела, о создании следственной группы, об изъятии и передаче уголовного дела (см. гл. 9). Как будет отмечено в гл. 14, дача помощнику поручения составить постановление о привлечении в качестве обвиняемого - это высшая степень доверия и признак признания следователем состоятельности начинающего юриста

Но есть еще одно объемное и важное, не просто задание, целое направление в деятельности общественного помощника и практиканта. Речь идет о производстве осмотра предметов, изъятых в ходе расследования уголовного дела. Часто возникающее у молодежи первоначальное мнение о том, что произвести качественный осмотр предметов очень легко, увы, ошибочно. Оно быстро меняется, как только в руки попадает реальный предмет. Сразу возникает масса вопросов, например: «А как правильно назвать эту вещь - пуловер, кофта, толстовка или свитер?», «А как описать вот эту деталь куртки, рядом с замком, около воротника?» и т.п.

Ситуация осложняется еще и тем, что следователи, особенно начинающие, иногда и сами не знают ответов на эти вопросы. Потому-то в ходе расследования часто допускаются грубые, а часто и непоправимые ошибки, влекущие признание доказательств недопустимыми по различным формальным основаниям. Примеров тому в следственной практике любых регионов множество. Вот типичный: в ходе обыска изымаются предметы, обозначенные в протоколе как «женские туфли». В протоко-

\section{${ }^{82} \mathrm{CM} \cdot 1.1$.}

${ }^{83}$ См. пункт 18 Положения об общественном помощнике следователя. Приложение 1. ле осмотра предметов они же обозначаются как «босоножки». Эксперт в описательной части заключения экспертизы при описании полученных на исследование предметов называет их же «шлепанцами», а в суд направляются «сандалии». На судебном следствии у судьи или адвоката возникает логичный вопрос: а куда же пропали изъятые в ходе обыска «женские туфли»? Далее защитник заявляет, а суд удовлетворяет ходатайство о признании недопустимыми всех доказательств, связанных с «пропавшими или подмененными», как утверждает защита, женскими туфлями (протоколов обыска, осмотра, заключений экспертиз и др.). Вот так, в силу небольших, чисто технических, на первый взгляд, ошибок может «разрушиться» любое обвинение по любому уголовному делу.

Выше были приведены рекомендации по обнаружению, фиксации и изъятию следов различного происхождения. Настоящую главу мы посвятим осмотру предметов, изъятых в ходе расследования по уголовному делу. Проекты протоколов и соответствующих постановлений может и должен составлять общественный помощник, практикант ${ }^{84}$. При этом важно помнить о следующих важных нормативных требованиях и неписаных правилах.

Так, изъятые предметы юридически неверно называть вещественными доказательствами до тех пор, пока следователем не будет вынесено об этом соответствуюшее постановление. Постановление о признании и приобщении к уголовному делу вещественных доказательств должно выноситься следователем только после их осмотра. Он может быть произведен следователем непосредственно в ходе следственного действия, посредством которого они изымаются (например, в ходе осмотра места происшествия). Осмотр предметов, обнаруженных при производстве обыска, осмотра места происшествия, местности, помещения, как самостоятельное следственное действие производится не во всех случаях. Только тогда, когда для такого осмотра требуется продолжительное время или их осмотр на месте затруднен (ч. 3 ст. 177 УПК РФ), и они не осматривались в момент их обнаружения при производстве перечисленных следственных действий. Отдельный осмотр нужен и тогда, когда предметы представлены подозреваемым, обвиняемым, потерпевшим, зашитником или другими участниками процесса (ч. 2 ст. 86 УПК РФ). Следователь, а по его поручению - помощник, практикант, производят осмотр предметов по месту производства предварительного расследования (чаще всего, в кабинете), обеспечивая их сохранность и возможность дальнейшего использования в качестве вещественных доказательств.

${ }^{84}$ Примеры этих и других документов можно скачать на сайте labatr.bsu.ru, ссылка на данное руководство, электронное приложение № 12. 
Для продуктивной и безошибочной работы с предметами - будущими вещественными доказательствами, не пренебрегайте рекомендациями, посвященными работе со следами различного происхождения (см. 7.2-7.7). Особое значение следует уделить изучению заключений экспертов и специалистов по вещественным доказательствам (если соответствующие экспертизы производились). Если возникли вопросы, на которые не сможет ответить следователь, следует проконсультироваться с экспертами, при необходимости их допросить.

Объекты, необходимость в описании которых может возникнуть в следственной практике, весьма разнообразны. Зачастую их описание сопряжено с использованием специальных незнакомых терминов, от максимальной точности которых зависит очень многое. Все эти термины знать и безошибочно использовать просто невозможно. Конечно же, существуют специальные рекомендации по осмотру различных объектов - от швейных иголок до бронетранспортеров. Имеются также справочные пособия, содержащие сведения о наиболее типичных для следственной практики объектах, их узлах, деталях. Однако такие справочные пособия не всегда имеются в горрайотделах и следственных управлениях. Их довольно сложно найти и в книжных магазинах.

Поскольку в следственной работе, чаще всего, приходится сталкиваться с предметами одежды, обуви и орудиями преступления, мы, не останавливаясь на общих вопросах тактики следственного осмотра ${ }^{85}$, постараемся особое внимание уделить описанию именно этих объектов.

Ниже приведены рисунки и описания, с некоторыми уточнениями заимствованные нами из справочного пособия под редакцией В.В. Филиппова - одной из лучших работ подобного типа ${ }^{86}$. На рисунках изображены предметы, без осмотра которых не обходится, пожалуй, ни одно уголовное дело о преступлениях против личности. Помимо наименования самих предметов, даны названия их составных частей, деталей ${ }^{87}$.

${ }_{85}^{85}$ Вопросы тактики и методики производства осмотра как следственного действия довольно полно и доступно описаны в учебниках криминалистики и специальных криминалистических публикациях. См., например: Осмотр места происшествия: практич. пособие / Под ред. А.И. Дворкина. М.: Юристъ, 2000. 336 с.

${ }^{86}$ Описание объектов криминалистического исследования: справочное пособие / Под ред. В.В. Филиппова. М.: ЭКЦ МВД России, 1995. 288 с.

${ }^{87}$ Мы намеренно не рассматриваем огнестрельное оружие в связи со сложностью устройства, многочисленностью деталей и их наименований. Подробно об этом см., например: Русаков Н.Н. Криминалистическое исследование оружия и следов его применения: Учебное пособие. Омск, 1981; Судебная баллистика и судебно-баллистическая экспертиза: учебник / Под ред. А. Г. Егорова. Саратов, 1998
Верхняя мужская одежда

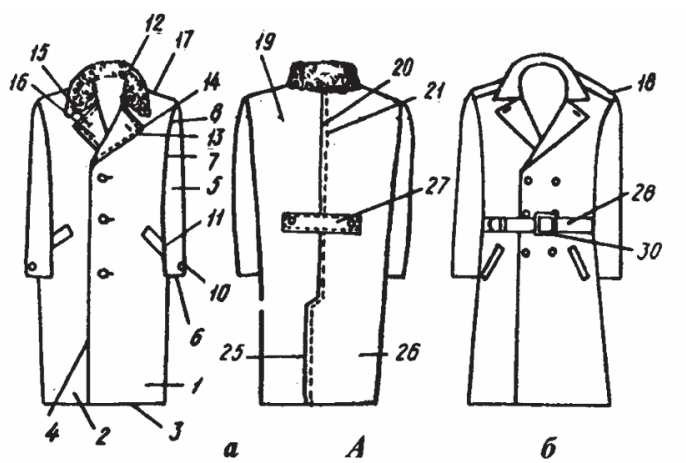

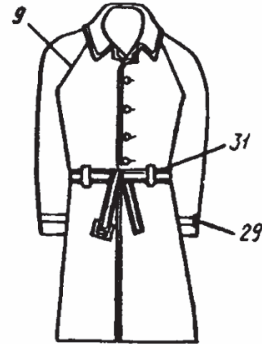
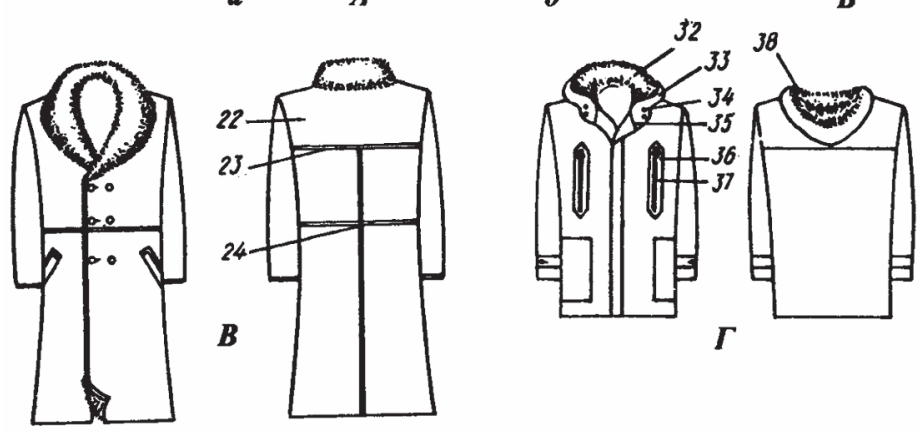

А. Пальто: $а$ - зимнее однобортное с меховым воротником; б- демисезонное.

Б. Плаш.

В. Дубленка

Г. Куртка.

1 -левая полочка; 2 - правая полочка; 3 - низ полочки; 4 - срез борта; 5 - рукав; 6 - низ рукава; 7 - пройма; 8- рукав втачной; 9 - рукав реглан; 10 - пуговица; 11 - карман; 12 -воротник меховой; 13 - срез лацкана; 14 - уступ лацкана; 15 - петля лацкана; 16 - отворот лацкана; 17 - плечевой шов; 18 - погон; 19 - спинка; 20-шов спинки; 21 - декоративная строчка; 22 - кокетка; 23 - шов кокетки; 24 - шов линии талии; 25- шлица; 26- правая сторона спинки; 27-хлястик; $28-$ пояс; 29 - пата; 30 - пряжка; 31 - шлевка; 32 - меховая отделка; 33 - капюшон; 34 - кнопка; 35 - шов капюшона; 36 - рамка кармана; 37 - застежкка-молния; 38 - срез капюшона 
Мужская одежда
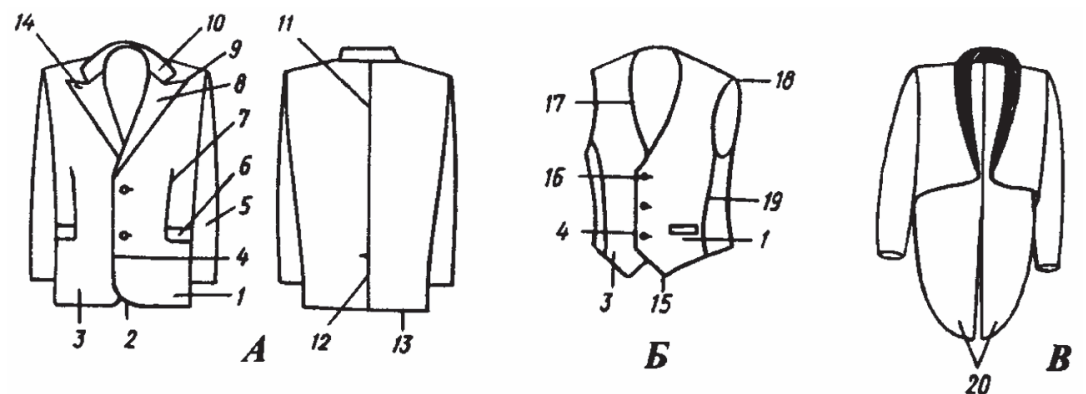

А. Пиджак.

Б. Жилет.

B. Фрак.

1 -левая полочка; 2 - низ полочки; 3 - правая полочка; 4 - срез борта; 5 - рукав; 6 - карман; 7 - переднебоковая вытачка; 8 -лачкан; 9 уступ лацкана; 10-воротник; $11-$ шов спинки; $12-$ шлица; 13 - низ спинки; 14 - петля; 15 - срез полочки; 16 - пуговица; $17-$ вырез горловины; 18 - пройма; 19 - переднебоковая вытачка; 20 - фалды

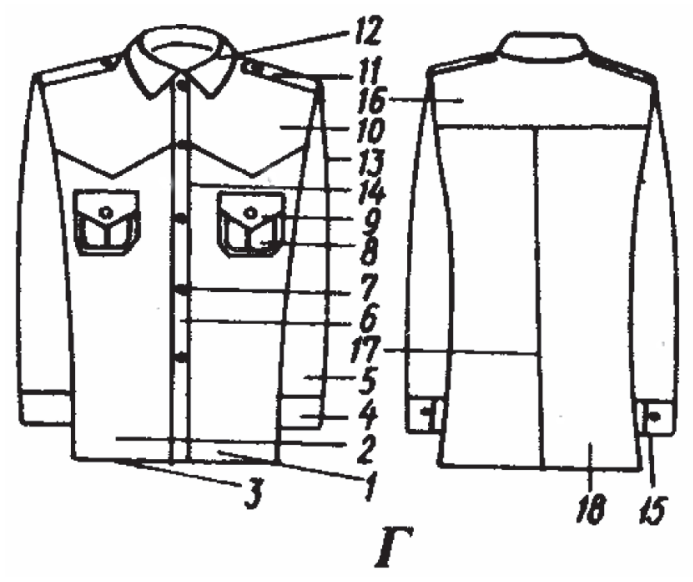

Г. Сорочка.

1 -левая полочка; 2 -правая полочка; 3 - низ полочки; 4-манжета рукава; 5-рукав; 6-планка; 7- пуговица; 8-карман; 9 - клапан; $10-\kappa o-$ кетка полочки; 11 - погон; 12 -воротник; 13 -окат рукава; 14 - срез борта; 15 - низ рукава; 16 - кокетка спинки; 17-шов спинки; $18-$ спинка
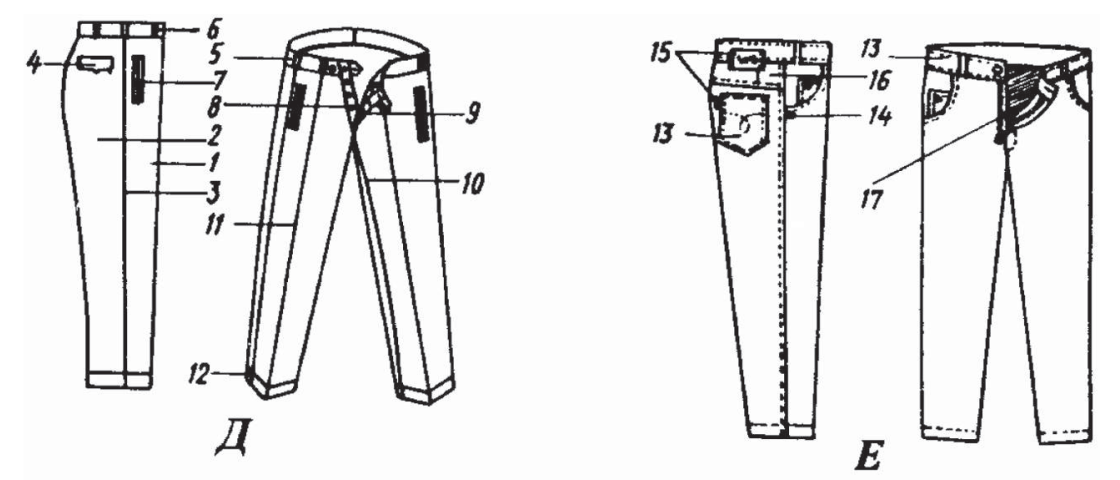

\section{Д. Брюки}

Е. Джинсы

1 - передняя половинка; 2- задняя половинка; 3 - боковой шов; 4- задний карман с клапаном; 5- пояс; 6- шлевка; 7 - боковой прорезной карман в рамку; 8- откос с пуговицами; 9- гульфик с петлями; 10 - шаговый (внутренний) шов; 11 - вертикальная складка-стрелка; 12 - манжета; 13 - декоративная строчка; 14 - заклепка; 15 - знак фирмы-изготовителя; 16-кокетка; 17-застежка-молния

Верхний трикотаж

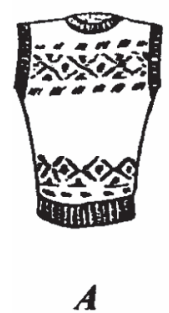

$\boldsymbol{A}$

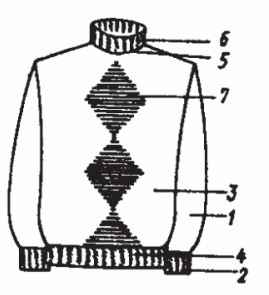

$\boldsymbol{E}$

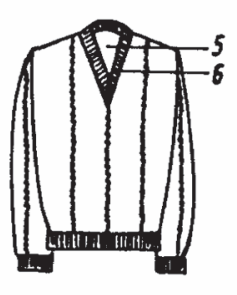

$\boldsymbol{B}$

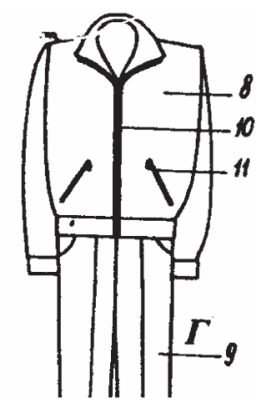

A. Безрукавка

Б. Свитер

В. Пуловер

Г. Спортивный костюм

1 - рукав; 2-манжета-резинка; 3- перед; 4- пояс-резинка; 5вырез; 6- отделка; 7- орнамент; 8- куртка; 9-брюки; 10-застежкка-молния; 11 - карман с застежккой-молнией 
Мужское нижнее белье

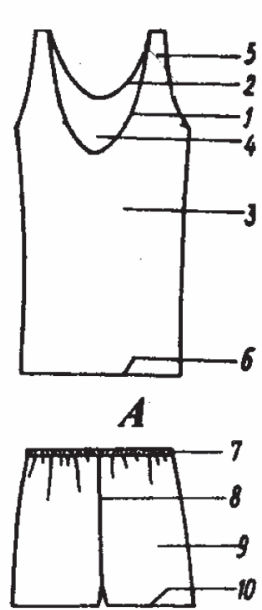

$\boldsymbol{b}$
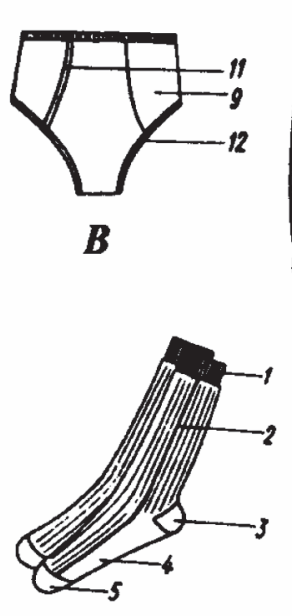

$\boldsymbol{\Gamma}$

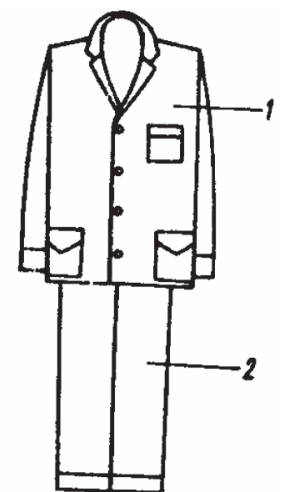

$\boldsymbol{E}$

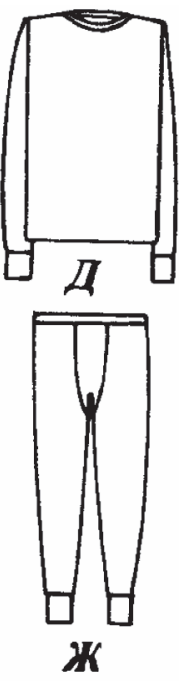

X
A. Майка

Б. Трусы

В. Плавки

1-вырез переда; 2-вырез спинки; 3- перед; 4-спинка; 5-бретель; 6-низ; 7 - резинка; 8- передний шов; 9- передняя половинка 10-низ; 11 - карман; 12 - вырез

Г. Фуфайка

Д. Кальсоны

Е. Пижама: 1 - куртка; $2-$ брюки

Ж. Носки: 1 - короткий бортик; 2-паголенок; 3 - пятка; 4 -след;

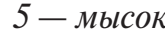

Аксессуары

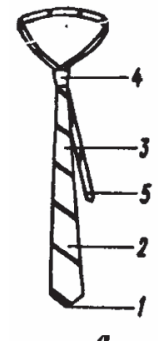

a

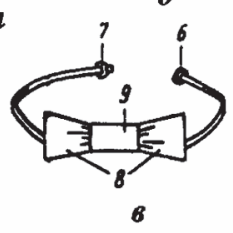

$\boldsymbol{A}$

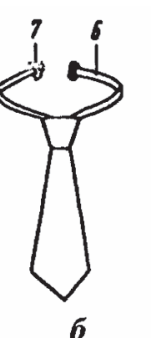

6

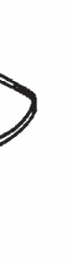

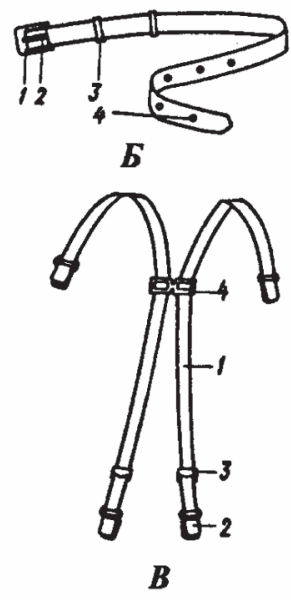
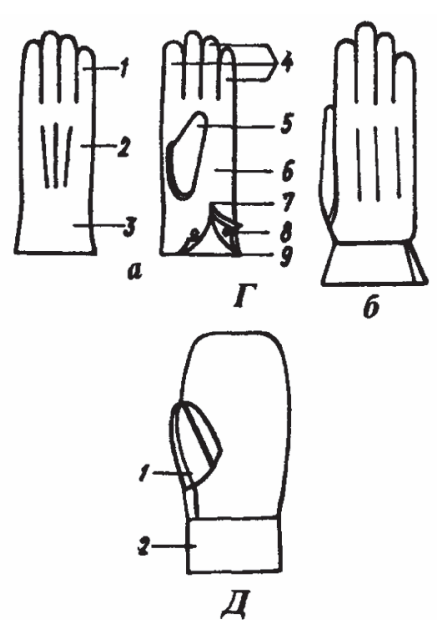

А. Галстуки: $а$-самовяз;б - регат; в - регат-бант; 1 -угол; 2 - широкий конеи; 3 - шейка; 4 - узел (головка); 5- узкий конеи; 6- резинка с передвижной пряжкой и петлей; 7-крючок; 8-концы, сложенные бантом; 9 - перехват.

Б. Ремень брючный: 1 - пряжка; 2-шпенек; 3-шлевка; 4-круглое отверстие.

В. Помочи (подтяжки): 1 - лента помочная; 2 - пата; 3 - пряжка помочная; 4 - задняя вставка

Г. Перчатки: $a-c$ застежккой; б-с крагами; 1 - пальцы; $2-$ цвиккель; 3 - тыльная сторона корпуса; 4 - клинья; 5 - большой палеи; 6ладонная сторона корпуса; 7-разрез; 8- застежкка; 9- подолик (нижняя часть корпуса).

Д. Рукавица: 1 - вшитый палец; 2 - манжета. 


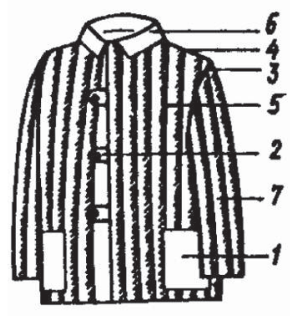

$\boldsymbol{A}$

\section{Специальная одежда}

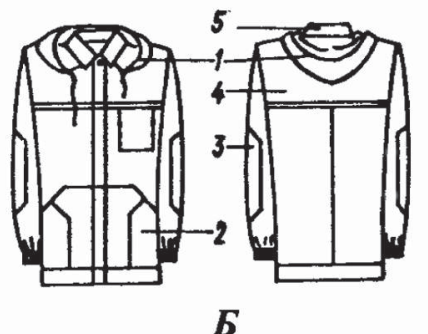

$\boldsymbol{B}$

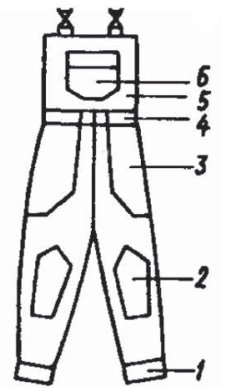

A. Телогрейка ватная: 1 - накладной карман; 2 - навесные петли; 3 окат рукава; 4 - плечевой шов; 5- швы сплошной простежки; 6-воротник отложной; 7-рукав

Б. Куртка рабочая: 1-капюшон; 2- накладные карманы; 3 - накладки на рукава; 4 - кокетка; 5 - воротник

В. Полукомбинезон: 1 - манжета; 2 - наколенники пристроченные; 3-карманы набедренные накладные; 4- пояс; 5- нагрудник; 6-кар ман нагрудника; 7 -лямка; 8 - пряжка

\section{Женская верхняя одежда}

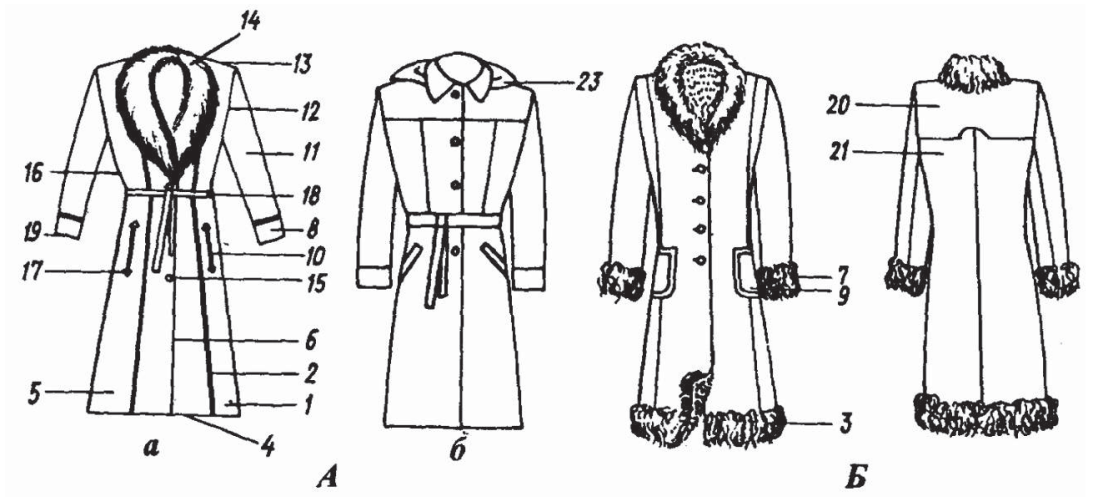

A. Пальто: $а$ - зимнее с меховым воротником; б-демисезонное

Б. Дубленка
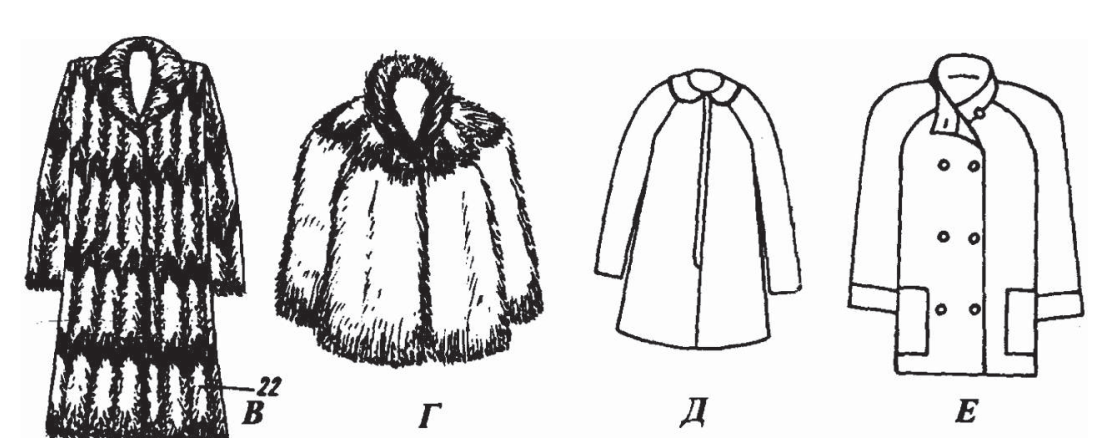

\section{В. Шуба}

1 -левая полочка; 2 - декоративный шов полочки; 3 -меховая опушка; 4- низ полочки; 5- правая полочка; 6-срез борта; 7-меховая опушка рукава; 8- манжета; 9- накладнои карман; 10- прорезнои карман; 11 - рукав; 12 - пройма; 13 - плечевой шов; 14 - воротник меховой; 15 - пуговица; 16 - боковой шов; 17 - отделка кармана; $18-$ пояс; 19 - низ рукава; 20-фигурная кокетка; 21 - спинка; 22 -меховая пластина; 23 - капюшон.

Г. Меховой жакет.

Д. Свингер.

Е. Полупальто.

Женская одежда
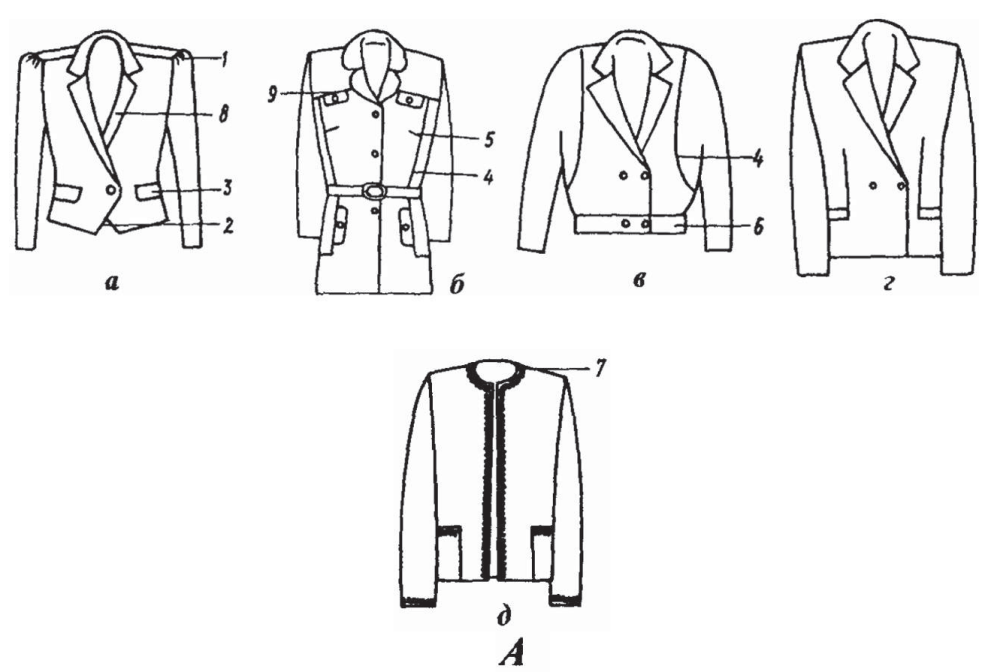
А. Жакеты: $a$ - облегающий; б - кардиган; в- типа «блузон»; г типа «мужсского пиджака»; д - типа «шанель»; 1 - сборка рукава; 2 срез борта; 3 - карман с клапаном; 4-переднебоковой шов; 5-вытач ка; 6- пояс; 7- вырез горловины; 8-лацкан; 9- скошенная кокетка.

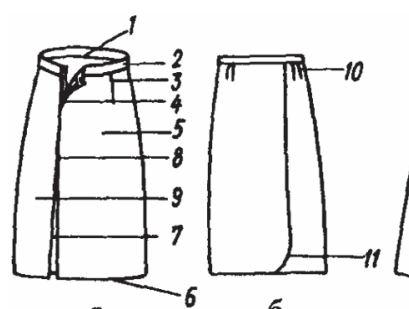

a

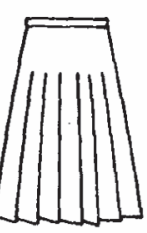

B

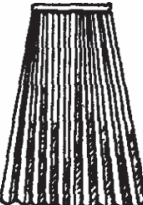

$\boldsymbol{2}$

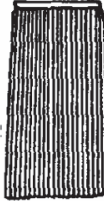

d

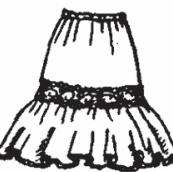

$e$

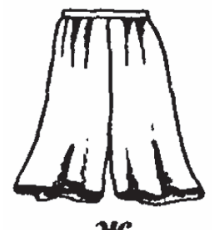

Б. Юбки: а - прямая двухшовная со складкой; б- прямая с запахом; в - расширенная книзу, в круговую складку; г -гофрированная («гофре»), д - плиссированная («плиссе»); $е-$ нижняя юбка; ж-юбка-брюки; 1 верхний срез юбки; 2- пояс; 3-вытачка; 4-застежкка; 5- переднее полотнище юбки; б - низ; 7-боковая складка; 8-боковой шов; 9-заднее полотнище; 10 - сборка; 11 - запах.
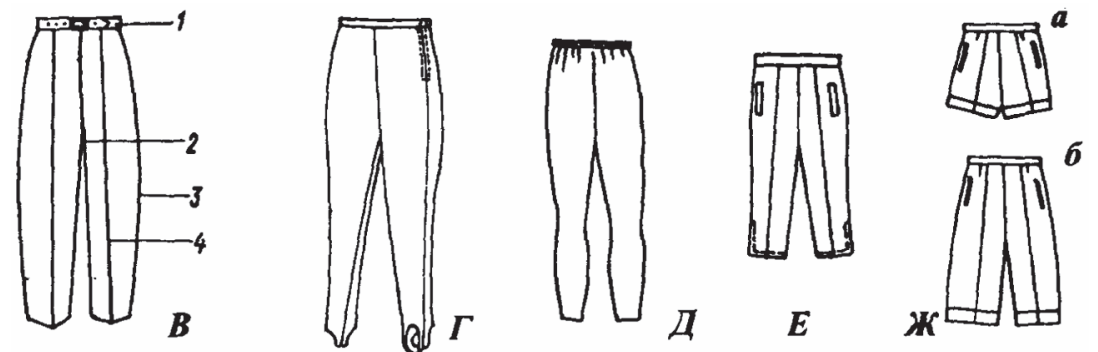

В. Брюки: 1 - пояс; 2- шаговый внутренний шов; 3 -боковой шов; $4-$ сгиб

Г. Леггинсы

Д. Лосины

Е. Бриджси

Ж. Шорты: $а$ - короткие; б-длинные («бермуды»)

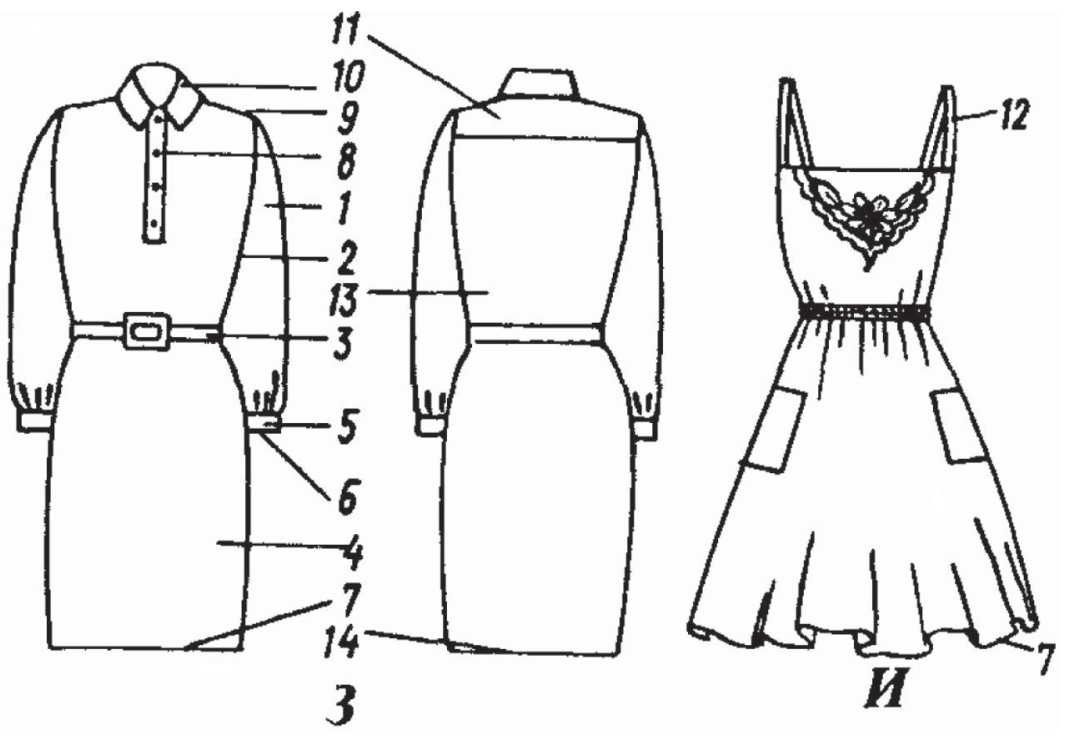

3. Платье

И. Сарафан

1-рукав; 2-боковой шов; 3- пояс; 4- перед; 5-манжета; 6-низ рукава; 7-низ переда; 8- планка; 9-плечевой шов; 10-воротник; 11 кокетка прямоугольная; 12 - бретель; 13 - спинка; 14 - низ спинки.
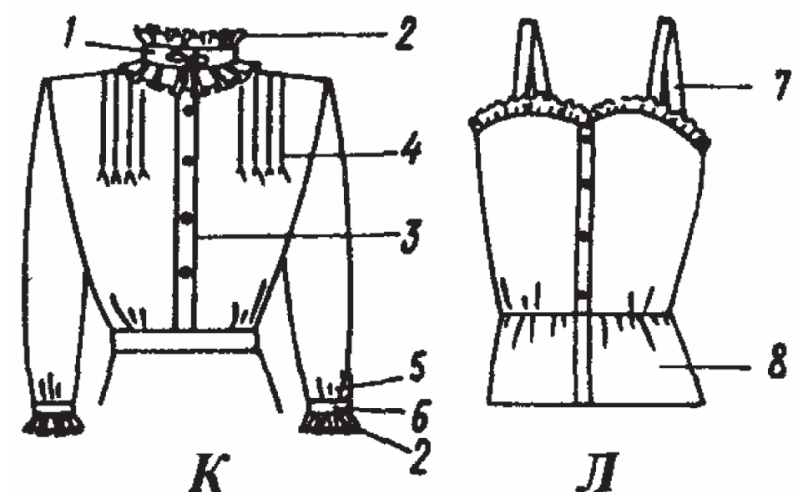

К. Блузка

Л. Корсаж

1-воротник; 2-рюш; 3-планка; 4-защипы; 5-сборка; 6-манжета; 7-бретель; 8-баска 


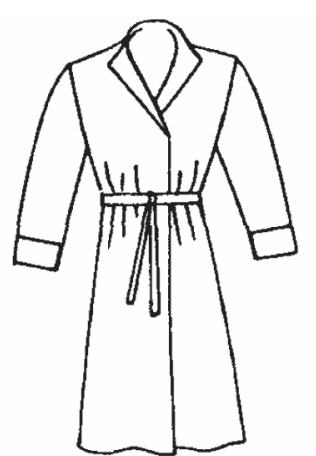

$M$

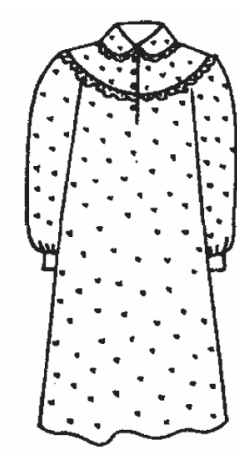

$\boldsymbol{H}$

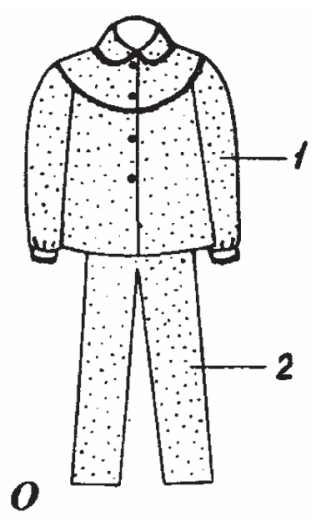

М. Халат с запахом на поясе

Н. Ночная сорочка

О. Пижама: 1 - куртка; 2 - брюки

Женское нижнее белье
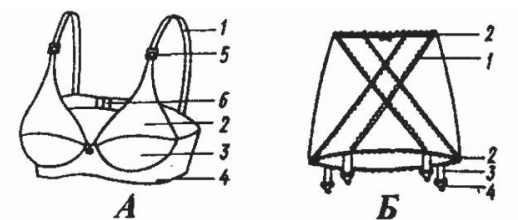

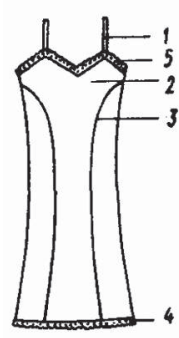

д

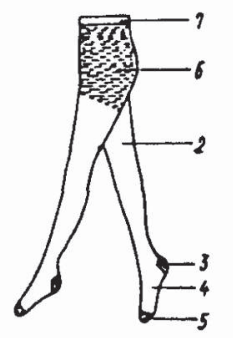

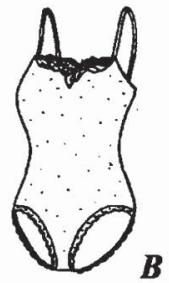

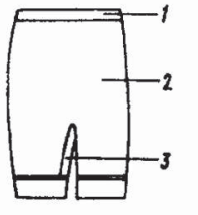

3
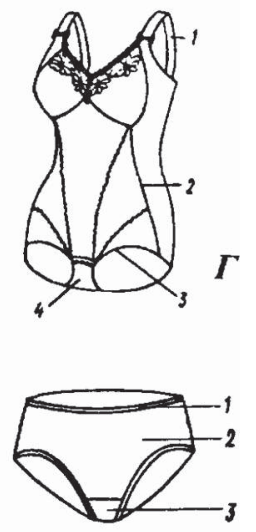

$\boldsymbol{H}$
А. Бюстальтер: 1 - бретель; 2- верхненаружная часть чашечки; 3- нижненаружная часть чашечки; 4- пояс; 5 - пряжка; 6- застежка Б. Пояс с подвязками: 1 - пояс; 2- резинки; 3 - эластичные ленты; 4-держатели для чулок

В. Комбидресс

Г. Грация: 1 - бретель; 2- переднебоковой шов; 3-вырез; 4-ластовица с застежкой
Д. Комбинация: 1 - бретель; 2 - лиф; 3 - переднебоковой шов; 4 отделка низа; 5 - отделка верха

Е. Колготки

Ж. Чулки

1-борт; 2- паголенок; 3-пятка; 4-след; 5-мысок; 6- торс;

7 - резинка

3. Панталоны

И. Трусы

1 - резинка; 2 - передняя часть; 3 - ластовииа.

\section{Детская одежда}

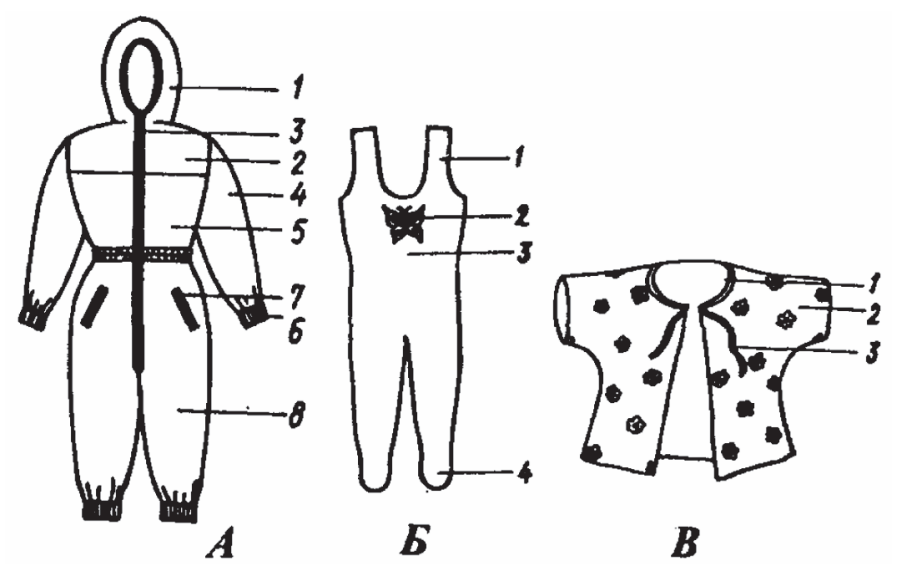

А. Комбинезон: 1 - капюшон; 2 - кокетка; 3 - застежка-молния; 4 рукав; 5 - нагрудная часть; 6 - манжета; 7-карман; 8- брючная часть

Б. Ползунки: 1-бретель; 2- аппликаиия; 3-нагрудник; 4-следовая часть

В. Кофточка-распашонка: 1 - вырез горловины; 2 - цельнокроеный с полочкой и спинкой рукав; 3 - завязка. 


\section{Детали одежды}
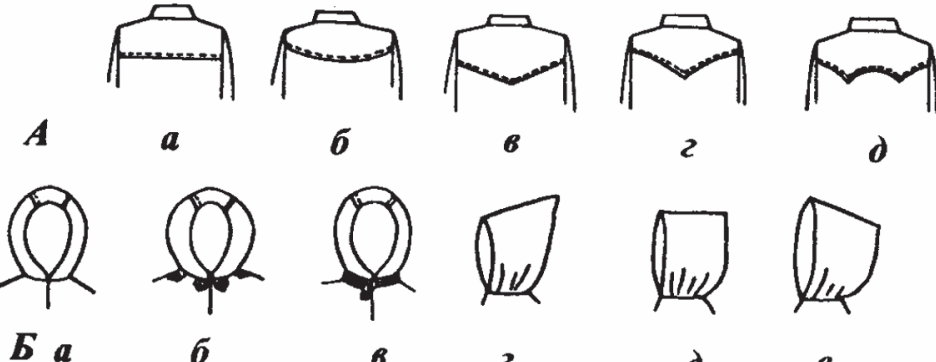

6

$\boldsymbol{6}$

2

d
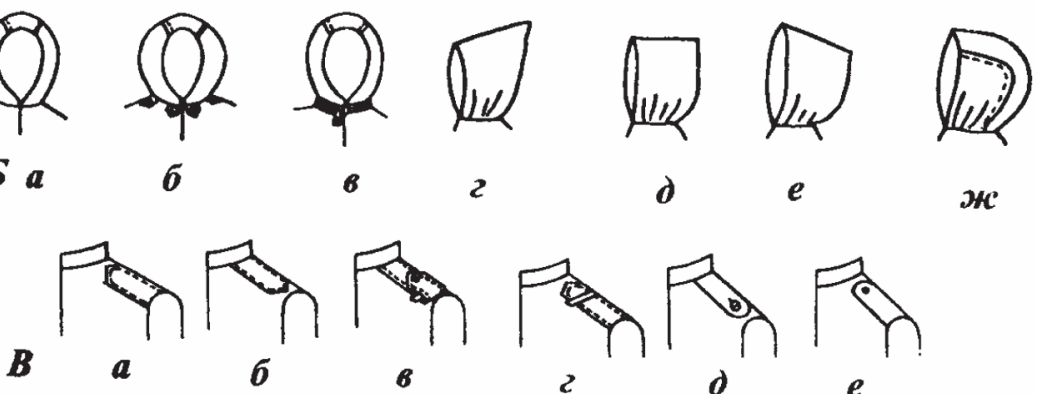

A. Кокетка: $а$ - прямоугольная; б- округлая; в- треугольная; г-мысообразная; д-с двумя мысами

Б. Капюшон: $a-$ притачной; б - сбемный на пуговицах; в - съемный на молнии; г - остроугольный; д - прямоугольный; $e-$ тупоугольный; ж⿻ закругленный

B. Погон: $a-$ вшит в головку рукава; б- вшит под воротником; в - пропущен через петельку у рукава; г - пропущен через петельку у воротника; д - пристегнут на пуговииу; $е$ - пристегнут на кнопку

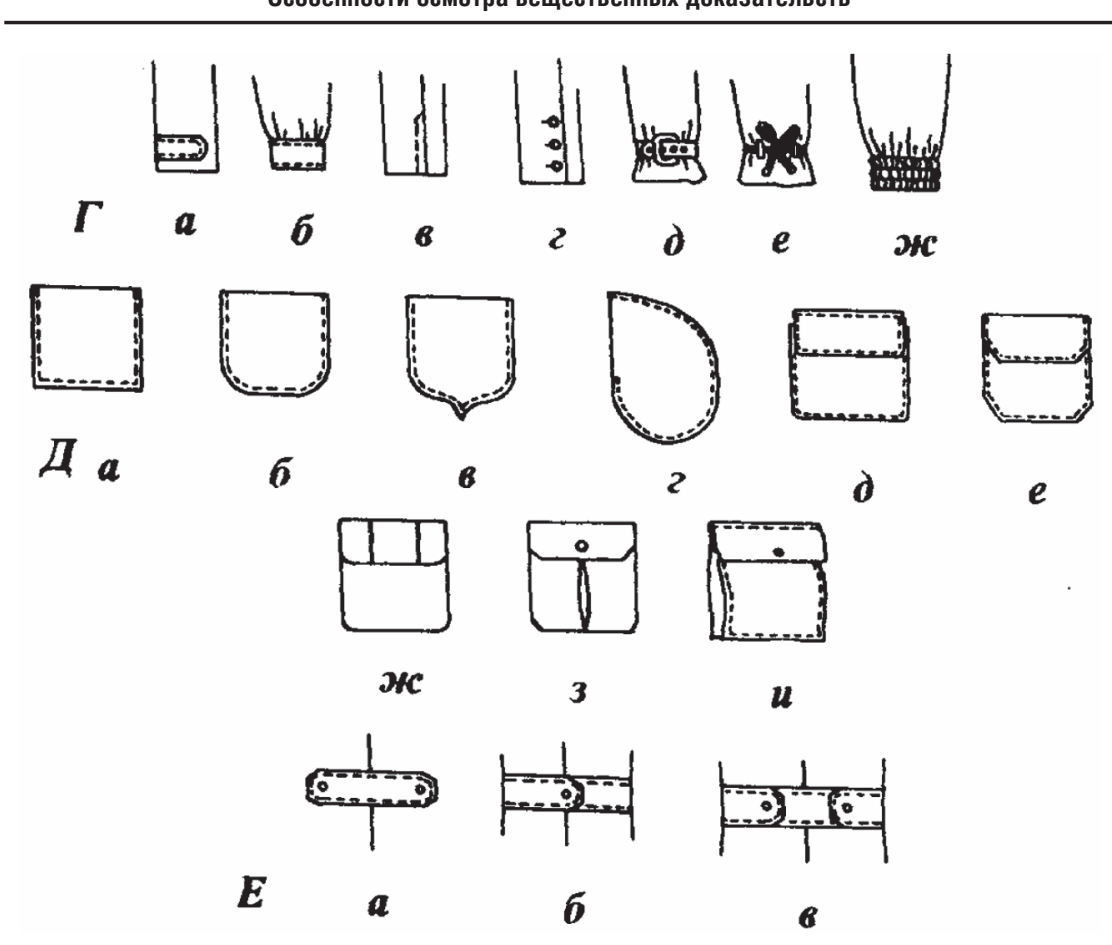

Г. Отделка рукава: $а$ - пата; б-манжета; в - илица; г - пуговицы; д - пряжка и ремень; $е$ - декоративный шнур; ж-на резинке

Д. Карман накладной: $a-$ прямоугольный; б-закругленный; в - фигурный; - -боковой; - - клапаном на полочке; $е$ - с клапаном на кармане; жсо складкой(ами) на кармане; з - со складкой на кармане; и - объемный

Е. Хлястик: $а$ - цельнокроеный; б-из двух деталей; в - из трех деталей 


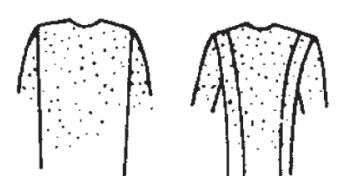

$\mathcal{K}$ $\boldsymbol{a}$

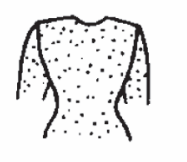

$\boldsymbol{6}$

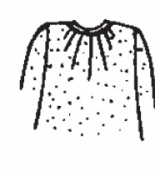

2
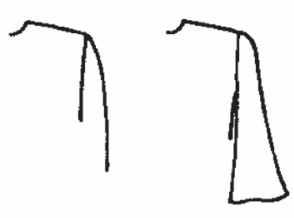

3

$\boldsymbol{a}$

И $\quad \boldsymbol{a}$

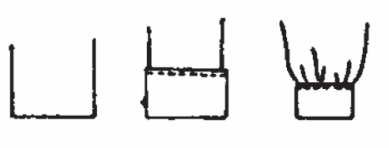

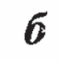

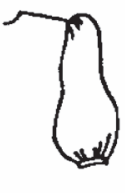

Giv

? $\partial$

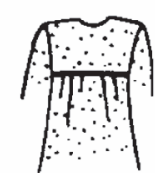

Ж. Силуэт: $a-$ прямой; б - полуприлегающий; в - прилегающий; г свободный от линии плеча; г - свободный от линии груди

3. Рукав: $а$ - прямой; б - расширенный книзу; в - с объемной головкой; г-«фонарик»; д-«крылышко»

И. Низ рукава: $а$ - гладкий; б - отворот; в - манжета; 2 - боковая застежкка; - разрез; е-на резинке; ж-с напуском

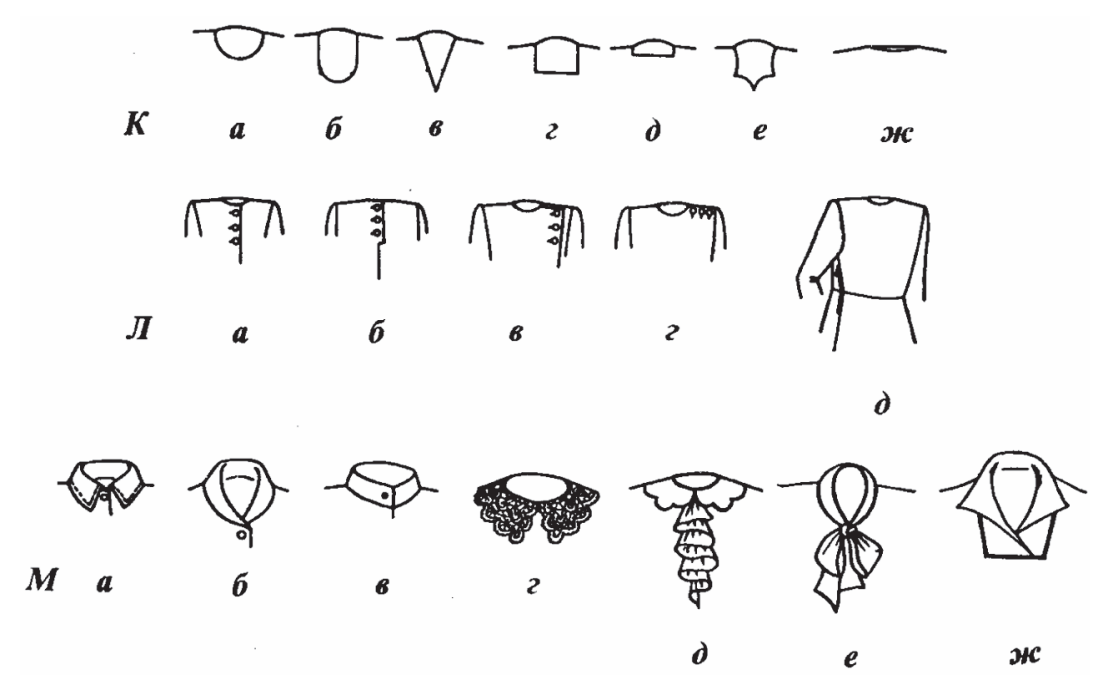

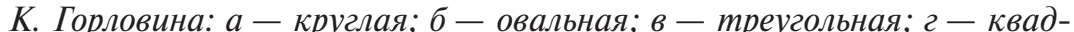
ратная; - прямоугольная; $е$ - фигурная; ж⿻ - «лодочка» («щель»)

Л. Расположение застежки: $a-$ спереди; б - сзади; в - сбоку; 2 - по линии плечевого шва; - по линии бокового шва

М. Воротник: $a-$ отложной; б- шалевый; в-стойка; г-кружевной; д - жабо; е - завязывающийся; ж⿻ - апаш. 


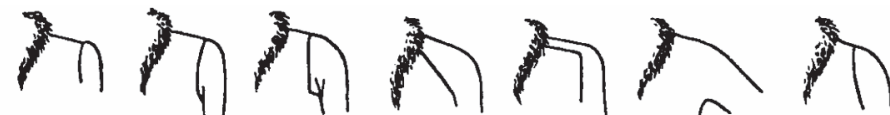 \\ $\boldsymbol{H}$ \\ $\boldsymbol{a}$ \\ 6 \\ e

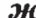
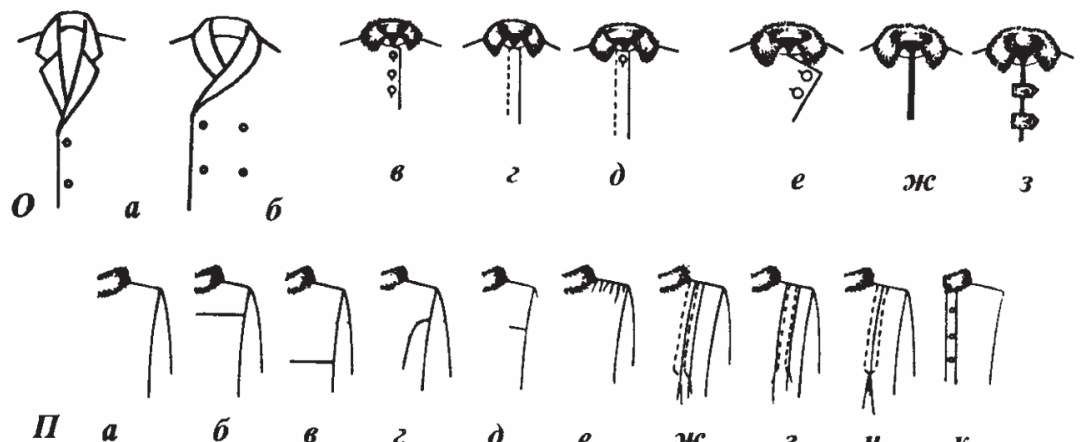

Н. Рукав: $а$ - втачной прямой; б - втачной с сильно углубленной проймой; в - с квадратной проймой; г - реглан; д-реглан-погон; $е-$ цельнокроеный; ж- полуреглан

О. Застежкка: $a$-однобортная; б-двубортная; в - центрально-бортовая открытая; г - центрально-бортовая потайная; д- центральнобортовая смешанная; $е$ - смещенная бортовая; ж⿻ - встык на крючках, з - встык на петлях-патах

П. Полочка: $a-$ цельнокроеная; б- с кокеткой; в - отрезная по линии талии; г - с отрезными бочками; д - с вытачками; $е-$ со сборками; ж - со складками односторонними; з - со складками двусторонними; $u-c$ встречной складкой; $к-c$ планкой
(1)

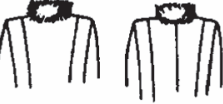

6
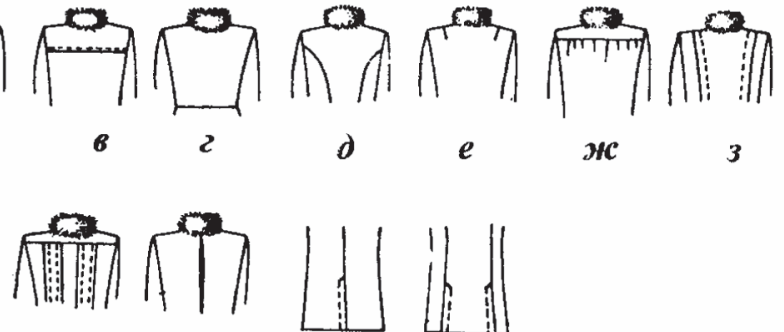

$\boldsymbol{e}$

жc

3

P. Спинка: $а$ - двухшовная цельнокроеная; б- трехшовная; в-скокеткой; 2 - отрезная по линии талии; д - с отрезными бочками; $e-c$ вытачками; ж - со сборками; з - со складками односторонними; и - со складками двусторонними; к-с встречной складкой; $л-$ со шлицей по центральному шву; м - со шлицами по боковым швам

\section{Головные уборы}

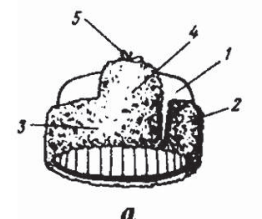

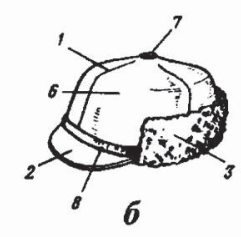
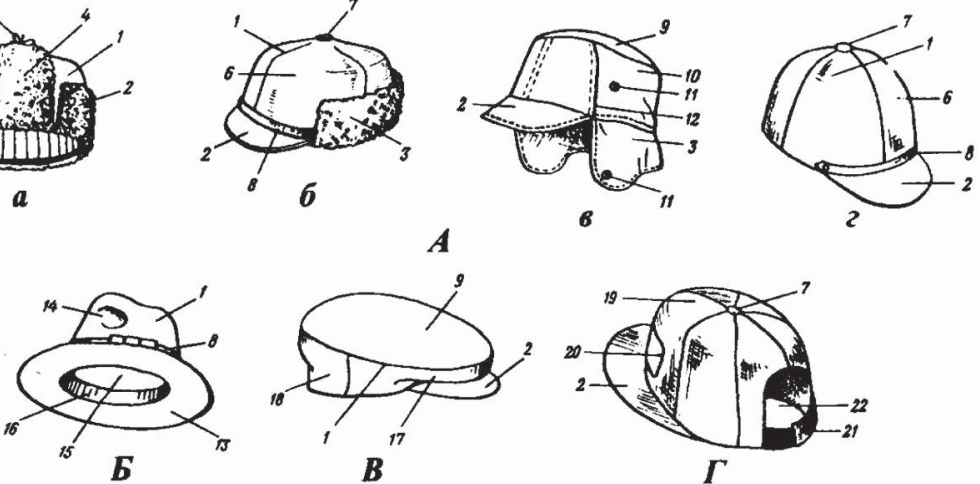

A. Шапки: $a$ - ушанка; б - зимняя спортивного типа с отделкой мехом; $в$ демисезонная спортивного типа; г - летняя спортивного типа «жокейка»

Б. Шляпа

B. Кепи

Г. Бейсболка

1-головка; 2-козырек; 3-бортик; 4- наушники; 5-завязки; б - клин головки; 7- пуговииа; 8- полоска; 9-донышко; 10 - стойка; 11 - застежка бортика; 12 - рельефная отделочная строчка; 13 - поля; 14 - замин; 15 - подкладка; 16 - налобник; 17 - передняя часть стенки; 18 - задняя часть стенки; 19 - передняя часть головки; 20 - торговая марка; 21 - резинка; 22 - вырез на задней части головки 

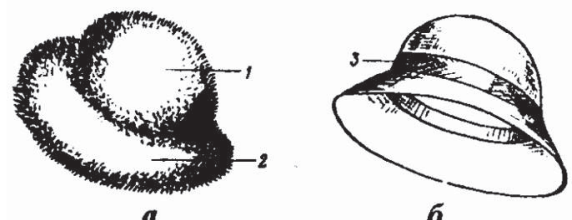
д
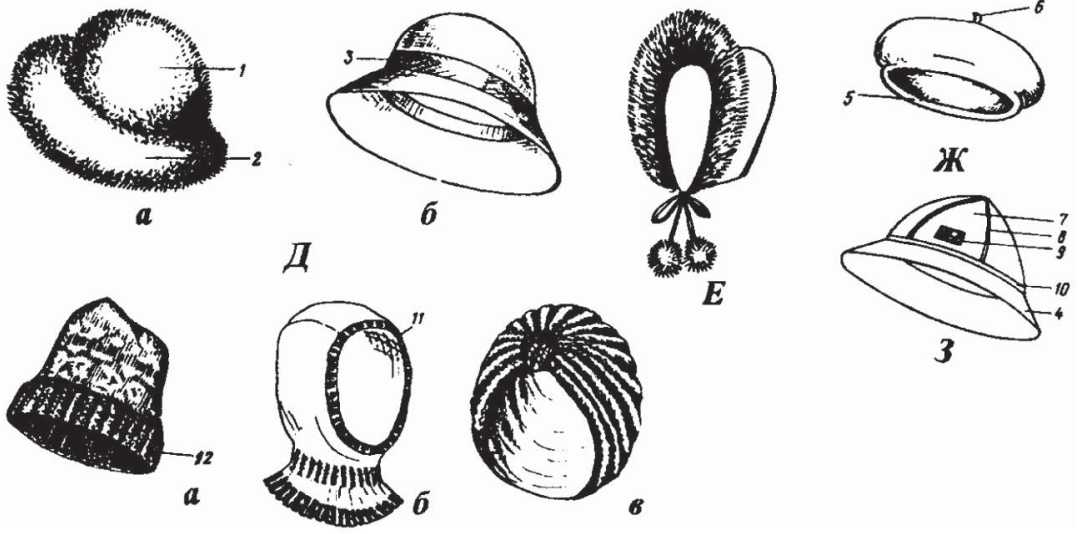

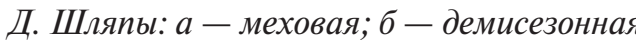

E. Капор с меховой оторочкой с помпонами

Ж. Берет

3. Панама

И. Вязаные головные уборы: а - типа петушок; б- типа «шлем»; в - типа «тюрбан»; 1 - головка; 2-стенка; 3 - лента; 4- поля; 5 налобник; 6- «антенка»; 7-клин головки; 8-рельефная строчка; 9 торговая марка; 10 - полоска; 11 - бортик-резинка; 12 - отворот

\section{Подошвы и каблуки}

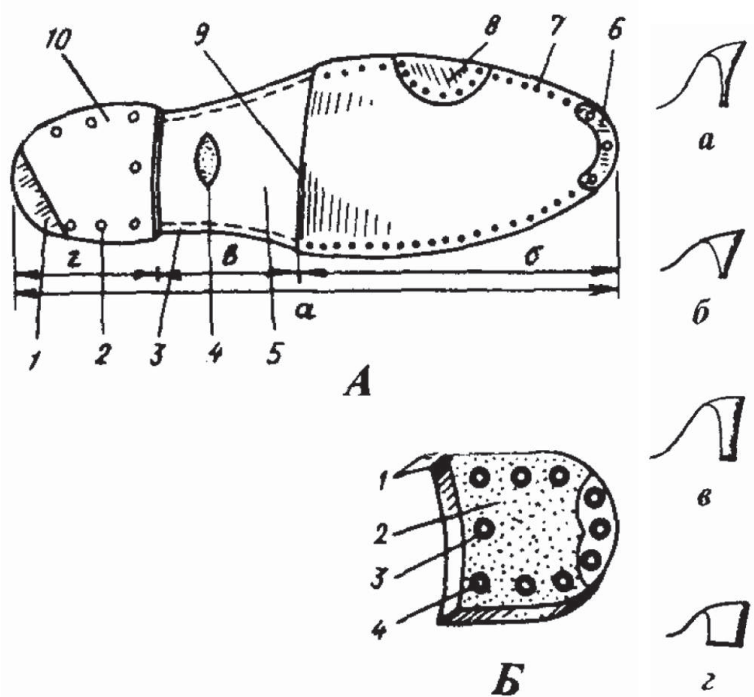

A. Подошва: 1 - косячок; 2-кольиевой наплыв; 3 - шов крепления промежуточной части; 4- - абричный знак (марка); 5 - цифры обозначения размера; 6 - подковка; $7-$ гвоздь крепления подметки; 8 - рубчик; 9 - срез подметки; 10 - каблук; $а$ - длина подошвы; б - длина подмет-

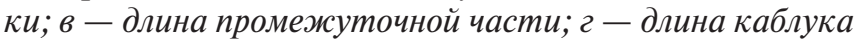

Б. Резиновая набойка: 1 - высота; 2 - ходовая поверхность (рифленая или гладкая); 3 - кольиевой наплыв; 4 - углубление для гвоздей 


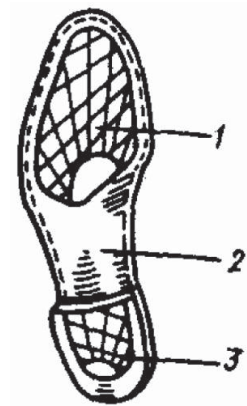

$\boldsymbol{a}$

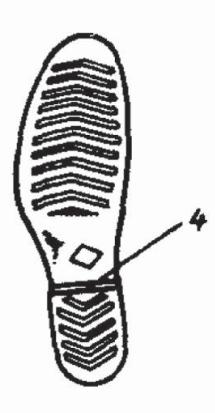

б

$\boldsymbol{B}$

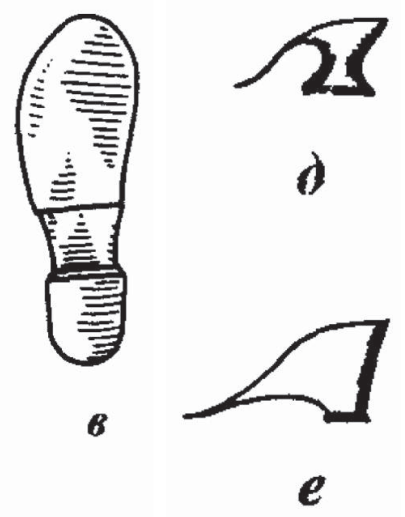

y

$\boldsymbol{a}$

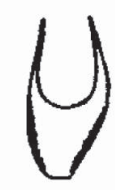

б

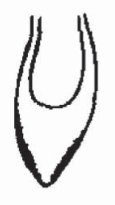

$\boldsymbol{B}$

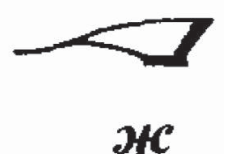

II

B. Типы подошв: $a$ - резиновая штампованная; $\sigma$ - резиновая с монолитным каблуком; в - кожаная с подметкой: 2 - рельефная ходовая поверхность подметки; 2 - гладкая неходовая поверхность; 3 - рельефная поверхность каблука; 4 - фронтальная поверхность каблука

Г. Формы носовых частей: $а$ - округлая, овальная; б-усеченная, со смягченными гранями; в - острая

Д. Каблуки: $a-$ высокий (ипилька); б-средний; в-высокий (стол-

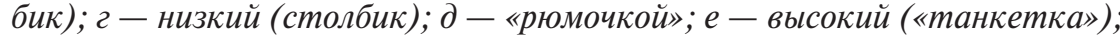
ж-низкий (танкетка)

\section{Мужская обувь}
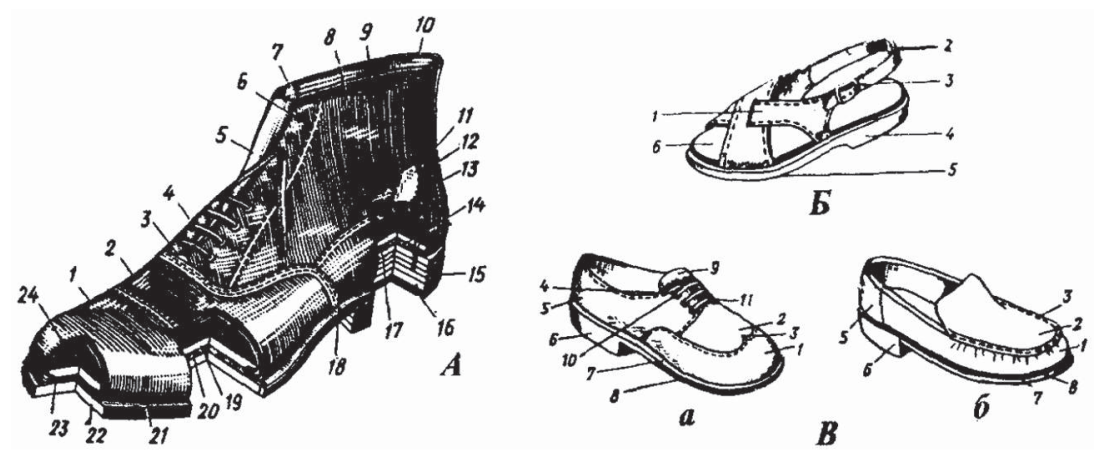

А. Мужской рантовый ботинок (основные детали): 1 - носок; 2 - союзка; 3-закрепка; 4-блочки; 5-язычок; 6-крючок; 7-подблочник; 8-береи; 9- основная подкладка; 10 - штаферка; 11 - внутренний ремень; 12 наружнный ремень (задинка); $13-$ задник; 14- подпяточник; $15-$ каблук; 16-набойка; 17-геленок; 18-задник; 19-стелька; 20- простилка; 21 - рант; 22 - подошва; 23 - губа стельки; 24 - жесткий подносок

Б. Сандалета: $1-$ ремни союзки; $2-$ ремни задней части; 3 - застежкка; 4 - каблук; 5- подошва; 6-носочная часть

В. Полуботинки: а - со шнурками и вставкой на союзке; б - бесшнурковый и со вставкой на союзке; 1 - носочная часть; 2- союзка; 3 - шов союзки; 4-блочок; 5-берец; 6-каблук; 7-рант; 8- подошва; 9язычок; $10-$ заклепка; 11 - шнурок

\section{Женская обувь}
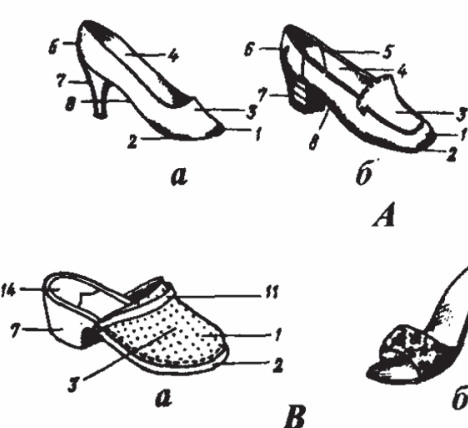

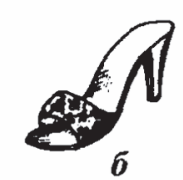

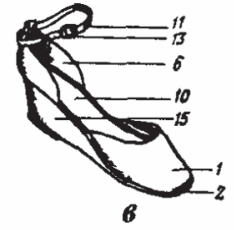

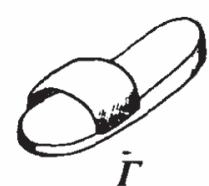

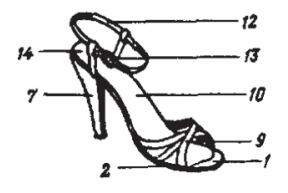

正

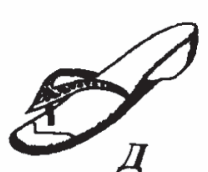

А. Туфли: $а$ - с вырезом «лодочка», на тонком высоком каблуке; б-закрытые, на толстом, наборном, средней высоты каблуке; в - сзакрытыми носочной и пяточной частями, открытой голеночной, на монолитной подошве 
Б. Босоножка ремешковая

B. Сабо: $a-c$ закрытой носовой и открытой пяточной частями; б-c открытой носовой и пяточной частями

1 - носочная часть; 2 - подошва; 3 - союзка; 4 - береи; 5 - шов бериа и задника; 6 - пяточная часть; 7-каблук; 8- средняя часть подошвы 9 - ремни союзки: 10 - челеночная часть; 11 - накладной чрезподбемный ремень; 12 - подпяточный и чрезподбемный ремень; 13 - застежкка; 14 открытая пяточная часть; 15 - танкетка

Г. Сандалия

Д. Шлепанеи

\section{Сапоги и полусапожки}

\section{Сапоги и полусапожки}

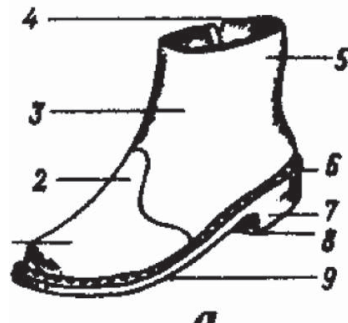

a

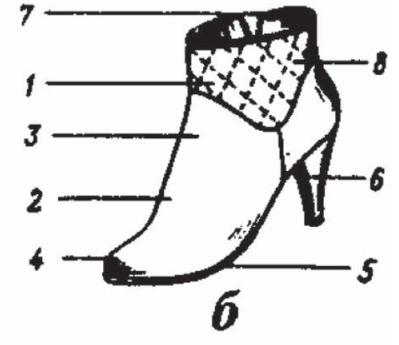

$\boldsymbol{A}$

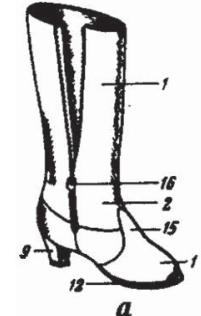

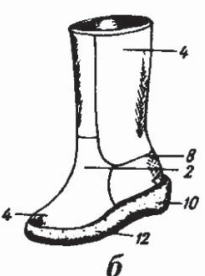

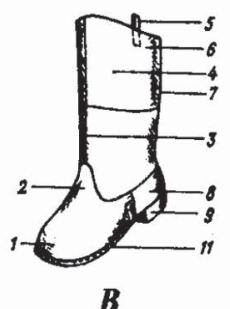

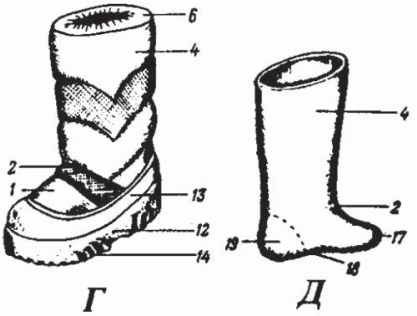

$\Gamma$
Б. Сапоги женские

a-на каблуке; б - на монолитной подошве

B. Сапог мужской

Г. Сапог «луноход», «дутыш»

Д. Валенок

1 - носочная часть; 2 - подьемная часть; 3 - передний шов; 4 - голенище; 5 - ушко; 6- верхняя часть голениша; 7-задний шов с прошвой; 8- пяточная часть; 9- каблук; 10 - каблучная часть; 11 - подметка; 12 - подошва; 13 - верхняя часть подошвы; 14 - нижняя часть подошвы; 15 - язычок; 16-застежка-молния; 17-пучок; 18 - стопа: 19-«подбойка»

\section{Спортивная обувь}
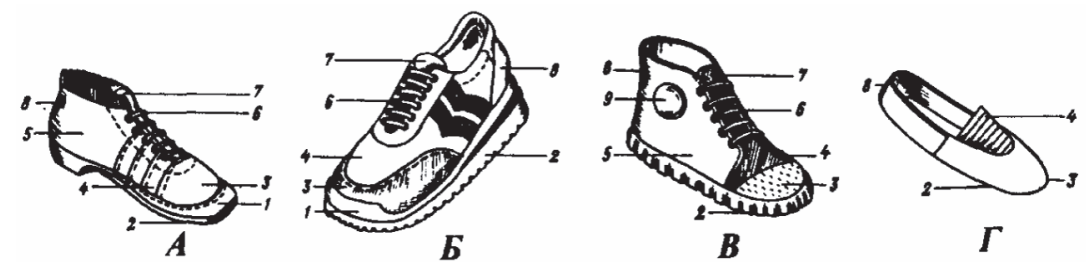

a-мужской: 1 - носочная часть; 2 - подъемная часть; 3 - голенише

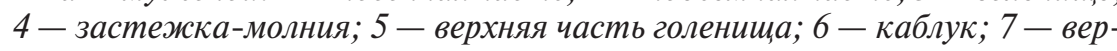
хняя часть каблука; 8 - нижняя часть каблука; 9 - подошва;

б-женский: 1 - голенище; 2 - подъемная часть; 3 -язычок; 4 - носочная часть; 5- подошва; 6-каблук; 7-застежкка-молния; 8-рельефная строчка

A. Лыжнный ботинок

\section{Б. Кроссовка}

B. Ked

Г. Гимнастическая туфля «чешка»

1-рант; 2- подошва; 3- носочная часть; 4-союзка; 5- береи; 6-блочок; 7-язычок; 8-задник; 9-налодыжник 


\section{Домашняя обувь}
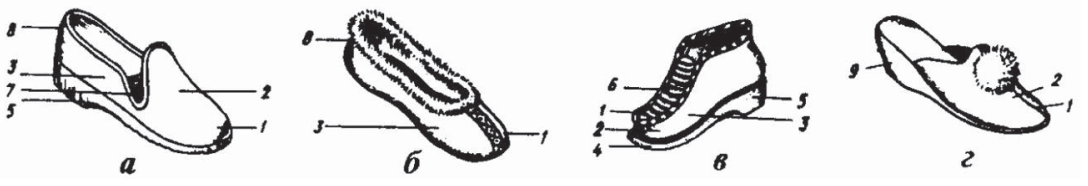

$a$ - комнатная туфля с резинкой на берие; б- комнатная туфля типа «лодочка»; в - высокая комнатная туфля со вставкой на союзке, 2 - комнатная туфля с открытой пяточной частью, на подошве типа «танкетка»; 1- носочная часть; 2- союзка; 3-береи; 4- подошва, 5- каблук; 6- вставка на союзке; 7-резинка на берце; 8- задняя часть; 9- подошва типа «танкетка»

\section{Детская обувь}
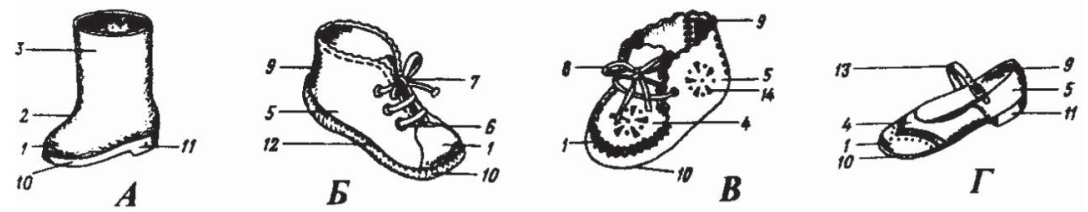

A. Валяный сапожок на резиновой подошве

Б. Ботинок

В. Пинетка

Г. Туфля

1 - носочная часть; 2- подъемная часть; 3 - голенище; 4 - союзка: 5-берец; 6-заклепки; 7- шнурки; 8-ленты; 9-задник; 10- подошва; 11 -каблук; 12 - рант; 13 - чрезподбемный ремень; $14-$ перфорация

\section{Топоры}

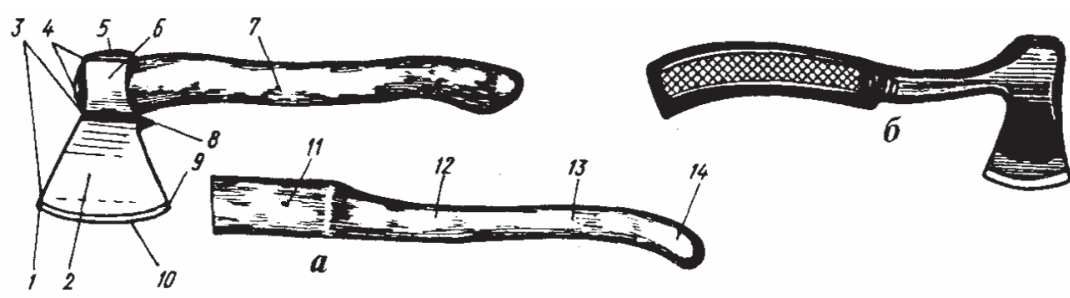

$a-$ плотничий: $1-$ носок; 2- шейка клина; 3-клин; 4- головка; 5- обух; 6- боковая стенка головки; 7- топорище; 8-бородка; 9- пятка; 10 - лезвие клина; 11 - закрепительная часть; 12 - средняя часть; 13 - захватная часть; $14-$ хвост

б- цельноштампованный
Кувалды и молотки

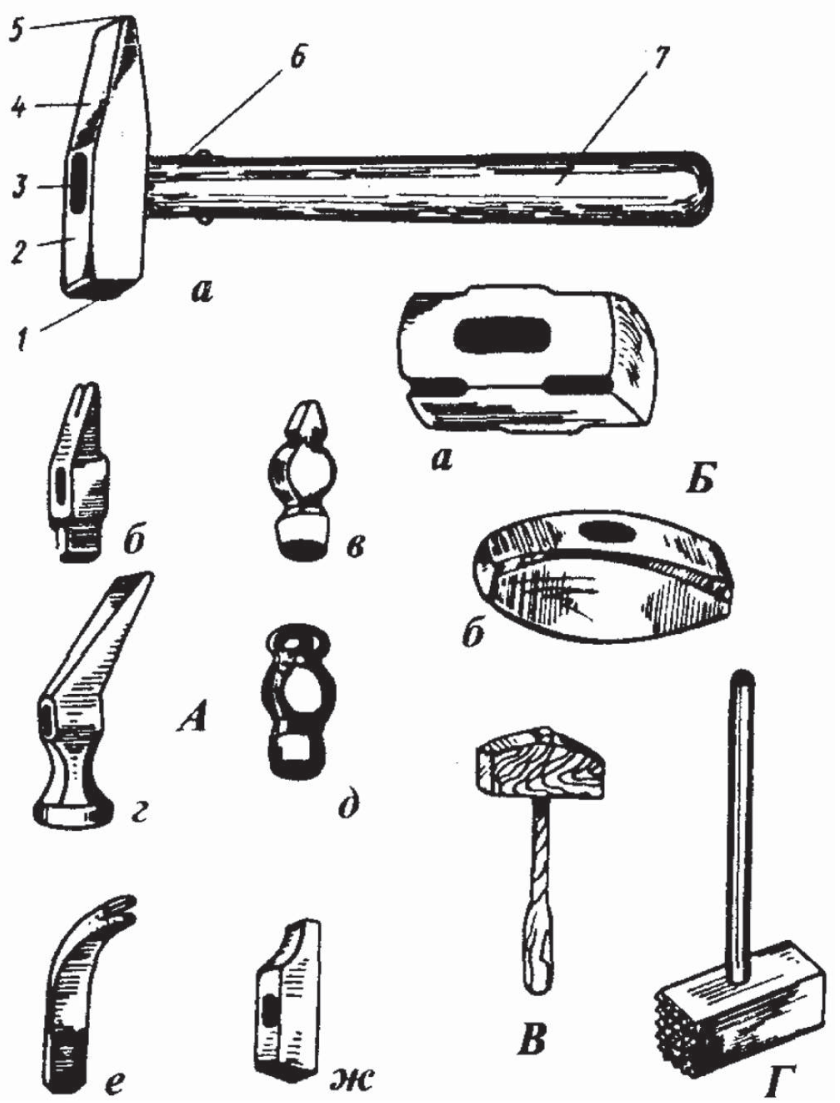

\section{A. Молотки:}

а-слесарный: 1 - квадратный боек; 2 - торцевая часть; 3 - головка ручки; 4-скос; 5- носок (вспомогательный боек); 6-металлическая накладка; 7- ручка; б - штукатурный; в - слесарный с круглым основанием и клиновидным вспомогательным бойком; г - сапожный; $д$ - слесарный с круглым основанием и шарообразным вспомогательным бойком; e - хозяйственный (общехозяйственного назначения); жк-столярный

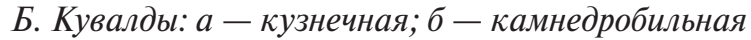

B. Киянка

Г. Бучарда (инструмент для обработки камня) 
Охотничьи ножи

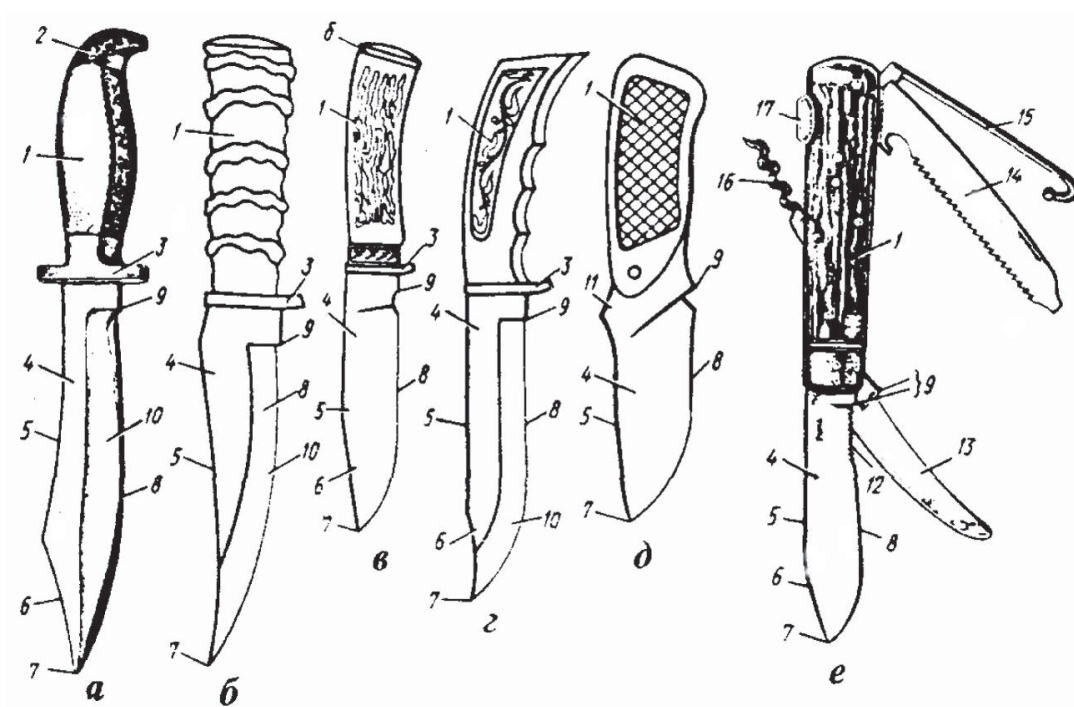

Д. Охотничьи ножи:

$a-2$ - общего назначения; д - специального назначения (для снятия шкуры); е- складной карманный многопредметный нож; 1 - рукоять; 2- навершие (головка, наконечник); 3 - перекрестие (упор); 4 - клинок; 5-обушок; 6 - скос обушка; 7-острие; 8-лезвие (рабочая кромка); 9 пятка; 10-заточка лезвия; 11 - упор для пальиа; 12 - пилка; 13 -клинок для подпарывания шкуры; 14 - пила с отверткой и сбемником бутылочных колпачков; 15 - крючок; 16 - штопор; 17-рычаг защелки клинка

\section{Глава 14}

\section{КАК ПОМОЧЬ СОСТАВИТЬ ПОСТАНОВЛЕНИЕ О ПРИВЛЕЧЕНИИ В КАЧЕСТВЕ ОБВИНЯЕМОГО}

Сразу следует оговориться, что материалы данной главы, в отличие от предыдущего, вряд ли могут быть использованы для того, чтобы доверить любому практиканту составление этого, пожалуй, самого сложного и важного документа уголовного судопроизводства. Такой скепсис имеет ряд оснований. Во-первых, на судебных стадиях именно из-за ошибок в тексте обвинения возникает наибольшее количество проблем. Во-вторых, практикант, чье пребывание в следственном подразделении чаще всего не превышает одного месяца, как правило, просто не успевает понять многочисленных тонкостей составления этого документа. Поэтому настоящие рекомендации адресованы, прежде всего, молодым следователям и только наиболее подготовленным общественным помощникам. Если следователь все же решил привлечь практиканта к решению этой задачи, то тщательно проверять и дорабатывать проект постановления все равно нужно самому следователю ${ }^{88}$.

Составители этих рекомендаций не стремились охватить все теоретические вопросы, касающиеся базовых знаний, получаемых при обучении в высших учебных заведениях. Все работающие в правоохранительных органах эту школу прошли. Акценты сделаны, прежде всего, на некоторые практические вопросы и проблемы составления постановления о привлечении в качестве обвиняемого (далее - обвинение), которые выработаны годами следственной работы и не нашли отражения в законодательстве и имеющейся в учебной и методической литературе. Рекомендации по составлению обвинения могут быть использованы и для составления других процессуальных документов.

Все предварительное расследование направлено на установление лица, совершившего преступление, изобличение его путем собирания, проверки и оценки доказательств, как изобличающих виновного, так и его оправдывающих. Все собранное облекается в процессуальную фор-

${ }_{88}^{8}$ В силу особой важности этого документа в Приложение 2 приведен образец его составления с комментариями составителей.

Другие примеры этого и других документов можно скачать на сайте labatr.bsu.ru, ссылка на данное руководство, электронное приложение № 13. 
му - постановление о привлечении в качестве обвиняемого, где аккумулируются полученные доказательства и иные сведения по делу. Насколько полно проведено расследование, настолько качественно будет составлено обвинение. А от качества составления обвинения зависит рассмотрение дела по существу в суде.

В идеале обвинение должно быть как формула в математике или физике, где все строго просчитано. Обвинение, как сжатая «пружина», которая запускает весь механизм уголовного преследования и правосудия. И малейшая неточность, ошибка, опечатка в этой формуле приведет к «сбою» в процессе рассмотрения уголовного дела.

Содержание обвинения должно быть взаимосвязанным, цельным, согласующимся между собой, легко воспринимаемым. Мастерство следователя заключается, прежде всего, в качестве составления обвинения.

В суде государственные обвинители, адвокаты, судьи руководствуются в основном этим документом, определяя, в чем именно обвиняется лицо. Доказательства и иные сведения в суде имеют значение только в том случае, если они подтверждают или опровергают именно те обстоятельства, объективные и субъективные признаки, которые описаны в обвинении. Если в нем не конкретизировано упомянутое, то даже если доказательства в ходе расследования собраны в полном объеме, суд может вынести оправдательный приговор или возвратить уголовное дело прокурору для устранения обстоятельств, препятствующих рассмотрению дела в суде, то есть для перепредъявления обвинения. Это вызвано тем, что суд при принятии решений не может выйти за рамки предъявленного обвинения независимо от наличия или отсутствия собранных доказательств.

Таким образом, составление обвинения по своей значимости равнозначно собиранию доказательств по делу. При этом недостатки, нарушения, допущенные в обвинении, в суде восполнить практически невозможно, а неполнота следствия, недостатки в доказательствах, влекущих их недопустимость, в суде часто можно восполнить предоставлением новых доказательств или восстановлением прежних путем проведения дополнительных экспертиз, допросов или иных процессуальных действий. Поэтому очень рискует тот следователь, который не придает должного значения составлению обвинения.

С чего же начинать?

Для начала следует:

- вспомнить основы теории квалификации преступлений;

- изучить действующее уголовно-процессуальное законодательство в части требований к составлению постановления о привлечении в качестве обвиняемого (гл. 23 УПК РФ), обвинительного заключения ст. 220 УПК РФ, приговора (гл. 39 УПК РФ).

1. Для уяснения первого необходимо вспомнить понятие квалификации преступления, а также определить основания, содержание, объем, условия, форму, формулу и формулировку обвинения. Эти понятия могут быть определены следующим образом.

Квалификация преступлений - это установление и юридическое закрепление точного соответствия между признаками совершенного деяния и признаками состава преступления, предусмотренного уголовно-правовой нормой ${ }^{89}$.

Под основанием обвинения следует понимать наличие достаточных доказательств, указывающих на совершение определенным лицом деяния, содержащего все признаки состава преступления, предусмотренного уголовным законом. Выделяются основания фактические (доказанное совершение общественно опасного деяния) и юридические (норма уголовного закона, указывающая на уголовную противоправность такого деяния) ${ }^{90}$.

Содержание обвинения включает объективные и субъективные признаки деяния, детерминирующие его уголовно-правовую квалификацию. Это, как правило, самый объемный фрагмент текста описательной части постановления. Содержание обвинения, как правило, начинается со слов: «По настоящему уголовному делу собраны достаточные доказательства, дающие основания для предъявления обвинения гр. , том, что он....» Заканчивается оно перед формулой и формулировкой обвинения ${ }^{91}$.

Так, обвинение в убийстве требует вменения противоправного умышленного причинения смерти другому человеку (ч. 1 ст. 105 УК РФ). Естественно, утверждение об этом в содержании обвинения требует фактической конкретизации путем указания на время, место, способ причинения смерти человеку, данные о личности потерпевшего, а также психическое отношение виновного к деянию и т.д. Содержание обвинения включает обязательные (например, причинение смер-

${ }_{89}$ См., например: Кудрявцев В.Н. Общая теория квалификации преступлений. Изд. 2-е, перераб. и доп. М.: Юристъ, 1999. С. 5.

${ }^{90}$ В разработке таких понятий, как основание, форма, формула, формулировка обвинения использовалась следующая работа: Макаров С.Д. Изменение квалификации преступлений в судебном разбирательстве // Уголовное право. 2003. № 2. С. 118.

${ }^{91}$ См. ниже. Если составов / эпизодов несколько, то содержание обвинения заканчивается перед последней из вменяемых формул и формулировок обвинения. 
ти умышленно - деяние, форма вины) и факультативные (например время, место, способ) признаки преступления, относящиеся к основаниям или условиям уголовной ответственности.

Объем обвинения - это совокупность инкриминируемых преступлений (основных составов), отягчающих, особо отягчающих либо смягчающих обстоятельств, с которыми закон связывает уголовную ответственность. Так, при вменении кражи (основной состав предусмотрен ч. 1 ст. 158 УК РФ), совершенной с незаконным проникновением в жилище (п. «а» ч. 3 ст. 158 УК РФ), в особо крупном размере (п. «б» ч. 4 ст. 158 УК РФ) объем обвинения включает эти три компонента, основным из которых является первый, а два последних - дополнительными. Понятно, что это единое преступление будет квалифицировано лишь по п. «б» ч. 4 ст. 158 УК РФ (см. правило ниже).

Форма обвинения предполагает отражение оснований, содержания и всего объема обвинения в обвинительном приговоре, а ранее - в постановлении о привлечении в качестве обвиняемого, обвинительном заключении, обвинительном акте.

От формы обвинения следует отличать формулу и формулировку обвинения.

Формула обвинения - это условное выражение обвинения в виде чисел и букв, указывающих на нормы УК РФ, нарушение которых вменяется обвиняемому. Формула обвинения указывается в целом ряде процессуальных документов, но, прежде всего, в резолютивной части обвинительного приговора, постановления о привлечении в качестве обвиняемого, обвинительного заключения и обвинительного акта. К примеру, в резолютивной части обвинения указывается решение следователя привлечь гр. К. (личные данные) в качестве обвиняемого по уголовному делу, предъявив ему обвинение в совершении преступления, предусмотренного П. «а», «е», «३» ч. 2 ст. 105 УК РФ.

Формулировка обвинения - это как бы описанная словами формула обвинения, то есть краткое изложение текста диспозиции уголовноправовой нормы, нарушение которой вменяется обвиняемому. Обычно формулировка идет сразу после формулы обвинения, через тире. В предыдущем примере формулы обвинения ее формулировка будет указывать на то, что гражданин К. совершил убийство, то есть умышленное причинение смерти двум лицам, общеопасным способом, по найму.

В этом примере демонстрируется важное правило: в случае, если лицо совершило деяние, подпадающее под один из альтернативных признаков состава преступления, то в формулировке обвинения надо описывать только этот один признак, а не переписывать все альтерна- тивные, указанные в законе. Так, в п. «а» ч. 2 ст. 105 Уголовный кодекс РФ предусматривает квалифицирующий признак убийства: «двух или более лиц»; п. «3» той же части - «из корыстных побуждений или по найму, а равно сопряженное с разбоем, вымогательством или бандитизмом». В примере по делу К., с учетом того, что он реально совершил, мы вменяем убийство только «двух лиц», а не «двух и более лиц», и только «по найму», а не весь текст пункта «з».

Во многих случаях формулировка обвинения может и должна выходить за рамки формулы. Например, действия подсудимого квалифицированы по п. «б» ч. 4 ст. 158 УК РФ - это формула обвинения. А формулировка обвинения должна указывать на совершение кражи, то есть тайного хищения чужого имущества группой лиц по предварительному сговору, с незаконным проникновением в жилище, в особо крупном размере. Обратите внимание на важное правило: особо квалифицирующие признаки (более тяжкие) в формуле ${ }^{92}$ обвинения как бы поглощают признаки основного состава и квалифицирующие (менее тяжкие). В нашем примере с кражей правоприменитель не должен составлять формулу так: «ч. 1, П. «а» ч. 3, п. «б» ч. 4 ст. 158 УК РФ». Пишем только: «П. «б» ч. 4 ст. 158 УК РФ» - то есть формулу самого тяжкого состава преступления.

2. До обсуждения процессуальных вопросов оформления обвинения необходимо сначала обратиться к УПК РФ, а именно к гл. 23 «Привлечение в качестве обвиняемого. Предъявление обвинения» и гл. 57.

Очень часто следователи забывают систематически обращаться к данным главам во время составления обвинения. Из ст. 171 УПК РФ «Порядок привлечения в качестве обвиняемого» следует, что при наличии достаточных доказательств, дающих основания для обвинения лица в совершении преступления, следователь выносит постановление о привлечении данного лица в качестве обвиняемого (ч. 1). В постановлении должны быть указаны: 1) дата и место его составления; 2) кем составлено постановление; 3) фамилия, имя и отчество лица, привлекаемого в качестве обвиняемого, число, месяц, год и место его рождения; 4) описание преступления с указанием времени, места его совершения, а также иных обстоятельств, подлежащих доказыванию в соответствии с п.П. 1-4 ч. 1 ст. 73 УПК РФ; 5) пункт, часть, статья УК РФ, предусматривающие ответственность за данное преступление; 6) решение о при${ }_{92}^{2}$ Но только в формуле! В формулировке обвинения все вменяемые лицу признаки основ-
ного состава и квалифицирующие (или привилегированные) признаки «расписываются» в обязательном порядке и точно в соответствии с текстом закона. 
влечении лица в качестве обвиняемого по расследуемому уголовному делу (ч. 2 ст. 171 УК РФ).

Часто невнимательно ознакомившись с упомянутыми требованиями закона, следователи при составлении обвинения допускают существенные нарушения, которые невозможно восполнить в последующем при рассмотрении уголовного дела в суде по существу.

В частности, при обвинении лица в совершении нескольких преступлений, предусмотренных разными пунктами, частями, статьями УК РФ, в обвинении должно быть указано, какие деяния вменяются ему по каждой из этих норм уголовного закона (ч. 3 ст. 171 УПК РФ) То есть обвинение должно быть изложено в тексте документа по следующей схеме:

«содержание обвинения по эпизоду № $1-$ формула № 1» - формулировка № 1; «содержание обвинения по эпизоду № $2-$ формула № 2 - формулировка № 2 и т.д.». Иногда в случае, когда обвинение содержит реальную (ч. 1 ст. 17 УК РФ) или идеальную совокупность (ч. 2 ст. 17 УК РФ) преступлений, такая схема изложения приводит к повторам фрагментов в тексте. Что ж, в разумных пределах это допустимо и необходимо.

Грубым нарушением закона является такое изложение: «Содержание обвинения по обоим эпизодам (№ 1 и № 2) вместе - формулы и формулировки № 1 и № 2 вместе».

К сожалению, желая написать покороче, без повторов, попонятнее с точки зрения логики и хронологии, а попросту из-за собственной некомпетентности, следователи часто не соблюдают данное требование закона.

При привлечении по одному уголовному делу в качестве обвиняемых нескольких лиц комментируемое постановление выносится в отношении каждого из них (ч. 4 ст. 171 УПК РФ).

Исходя из требований п. 4 ч. 2 ст. 171 УПК РФ, в постановлении о привлечении в качестве обвиняемого должны быть указаны обстоятельства, подлежащие доказыванию, предусмотренные ст. 73 УПК РФ, а именно: 1) событие преступления (время, место, способ и другие обстоятельства совершения преступления); 2) виновность лица в совершении преступления, форма его вины и мотивы; 3) обстоятельства, характеризующие личность обвиняемого; 4) характер и размер вреда, причиненного преступлением; 5) обстоятельства, исключающие преступность и наказуемость деяния; 6) обстоятельства, смягчающие и отягчающие наказание; 7) обстоятельства, которые могут повлечь за собой освобождение от уголовной ответственности и наказания.
Кроме того, указания ст. 171 и 73 УПК РФ необходимо выполнять не только когда возникла необходимость в составлении и предъявлении обвинения, но и с первого дня предварительного расследования. Неполнота следствия, невыполнение даже незначительной части диспозиций указанных статей УПК РФ в дальнейшем не позволят составить законное и обоснованное обвинение.

Далее обязательно нужно применить незаполненный, не примененный ранее по другому делу бланк постановления о привлечении в качестве обвиняемого. Повторим, что многие следователи, ошибочно полагая, что таким образом экономят время и облегчают себе работу, при составлении обвинения используют ранее составленные аналогичные постановления о привлечении в качестве обвиняемого. Настаиваем, что бланк постановления нужно взять чистый. Там не должно содержаться никаких индивидуальных сведений, которые с каждым новым уголовным делом или обвиняемым меняются. Такая экономия рабочего времени рано или поздно приведет к грубейшим процессуальным нарушениям, что подтверждается следственной практикой.

Ежегодно по России десятки уголовных дел «разваливаются» в суде или возвращаются прокурору для устранения выявленных процессуальных нарушений только потому, что из «чужого» обвинения остались дата, номер дела, анкетные данные обвиняемого или потерпевшего, формула обвинения или ее отдельные элементы и т.п.

Если по одному делу, по одному и тому же эпизоду проходят 2 и более обвиняемых, целесообразно скопировать только текст содержание обвинения. Но ни в коем случае нельзя слепо копировать все постановление, в том числе формулу и формулировку обвинения, резолютивную часть документа. Именно в формуле, формулировке, резолютивной части, чаще всего, допускают техническую ошибку: в содержании обвинения указано, что преступление совершил гражданин А., а например, в абзаце с формулой и формулировкой указано, что преступление совершил гражданин Б. Повторим, в бланке перед началом составления постановления должны быть только сведения, которые никогда не меняются.

Особое внимание следует уделить дате вынесения постановления. В ч. 1 ст. 172 УПК РФ указано: «Обвинение должно быть предъявлено лицу не позднее 3 суток со дня вынесения постановления о привлечении его в качестве обвиняемого в присутствии защитника, если он участвует в уголовном деле». Следовательно, заполняя изначально чистый бланк, можно избежать указанных технических ошибок. Не ошибитесь в подсчете дней до предъявления обвинения! 
Еще раз следует напомнить, что перед составлением документа необходимо точно определиться с квалификацией деяний. Даже если считаете, что помните статью наизусть, все равно настоятельно рекомендуем - прочитайте: сами статьи УК РФ ${ }^{93}$; обязательно постановления Пленума Верховного суда РФ, если таковые по вопросу имеются, а также иную, хотя бы опубликованную ${ }^{94}$ судебную практику по соответствующим преступлениям; не менее двух комментариев к соответствующим статьям и при необходимости иную учебную и научную литературу. Определившись с квалификацией преступлений, объемом обвинения, необходимо перейти к следующему этапу.

Это составление содержания обвинения: описание всех преступных деяний лица, объективных и субъективных признаков конкретного преступления. Все, что касается формулы и формулировки обвинения, рекомендуем составлять и редактировать позднее.

Таким образом, следующим этапом является изучение собранных материалов уголовного дела. Для этого нужно по ходу чтения показаний свидетелей, потерпевшего, подозреваемого, обвиняемого выписывать действия потерпевшего и виновного лица сразу в проект обвинения. Очень важно вписывать указанные в допросах конкретные действия и бездействие не на каждого из допрашиваемых в отдельности, а как бы сводить все в одно целое. Показания разных лиц по одному обстоятельству сразу показывают недостатки, неполноту проведенного допроса, различия, противоречия, отсутствие необходимых сведений. Это важно, так как, приводя конкретные действия по конкретному поводу в одном месте по вариантам допросов различных лиц, сразу будут видны противоречия. Их необходимо устранять дополнительными следственными действиями (допросами, очными ставками и т.д.). Неважно, что первоначально все это будет неграмотно оформлено, трудно читаемо, несогласованно. Все недостатки позднее будут ликвидированы. Главное не пропустить, учесть все конкретные признаки.

Отсутствуюшие сведения, которые не установлены на момент начала составления проекта обвинения, целесообразно как-то обозначать, например, нижним подчеркиванием, чтобы этот недостаток был

${ }_{93}$ Используйте строго только действующую редакцию постоянно меняющегося УК! Удалите из кабинета и компьютера все устаревшие редакции кодексов. Слишком часто и слишком дорого обходятся стороне обвинения ошибки с недействующими редакциями норм уголовного и уголовно-процессуального закона.

${ }^{94}$ В Бюллетене Верховного суда РФ и СССР. Подборки несложно найти, например, в СПС «Консультант Плюс» или на сайте Верховного суда РФ. позднее замечен. Затем можно продолжать составлять документ. Для восполнения недостающих сведений необходимо срочно выполнить соответствующие следственные действия, после чего внести добытую информацию в содержание проекта обвинения.

Например, в формулировке обвинения в совершении преступления, предусмотренного ч. 1 ст. 290 УК РФ - получение взятки, часто пропускают термины (обязательные признаки состава) - «...лично», «через посредника», а также «...в виде денег, ценных бумаг...»; по ч. 1 ст. 132 УК РФ - насильственные действия сексуального характера, часто упускают фразу: «иные действия сексуального характера»; по ст. 319 УК - применение насилия к представителю власти, термин «публичное» и т.д. Достаточно пропустить подобные термины в формулировке, и вот уже в суде адвокат или обвиняемый с удовольствием начинают оспаривать законность и обоснованность предъявленного обвинения, а государственный обвинитель проклинает вашу неграмотность...

Вместе с тем нельзя приводить в содержании и тем более в формулировке обвинения лишние, не предусмотренные диспозицией конкретной статьи признаки, находящиеся в противоречии с вменяемым составом преступления. Так, в кассационной инстанции был отменен приговор по делу, по которому лицо было осуждено по ч. 1 ст. 290 УК РФ. В приговоре по ошибке было указано, что виновное лицо получило взятку и «из корыстных побуждений» и в то же время «из иной личной заинтересованности». Получение взятки - преступление, совершаемое только по корыстным мотивам. Ошибку допустил следователь, а судья невнимательно изучив обвинение, перенес ее в приговор.

Таким образом, если в обвинении будут приведены взаимоисключающие признаки состава, например, в формулировке обвинения по ст. 293 УК РФ - халатность: «... должностное лицо не исполнило своих обязанностей вследствие недобросовестного отношения к службе», а в содержании обвинения: «должностное лицо, добросовестно заблужждаясь...», то последствия будут самые печальные. Судом такое противоречие будет расценено как неконкретизированное обвинение, что может привести к оправдательному приговору или, как минимум, к возвращению дела прокурору в порядке ст. 237 УПК РФ.

Чтобы исключить данные нарушения при составлении текста обвинения, еще раз подчеркнем: необходимо внимательно читать соответствующие статьи УК РФ, где изложены все признаки состава данного преступления. Разумеется, все вменяемые лицу признаки диспозиции статьи УК РФ должны быть не только указаны в формуле и формулировке, но и подробно раскрыты, обоснованы в содержании обвинения. 
Часто для обоснования наличия состава преступления, имеющего бланкетную диспозицию, необходимо прочитать и привести в содержании обвинения законодательство и подзаконные нормативные акты (служебные инструкции и т.п.). При этом необходимо указывать как название нормативного акта (в том числе номер, дату и кем принят), номер статьи и пункта, так и излагать собственно фрагмент документа, то есть норму, которая имеет отношение к конкретному преступлению.

Это особенно важно при составлении обвинения по служебным преступлениям, преступлениям, связанным с нарушением различных правил (ст.ст. 143, 263-264 УК РФ и др.). Так, по делу в отношении следователя П., обвиняемой по ч. 1 ст. 285, п.п. «б», «В», «Г» ч. 2 ст. 158 УК РФ, в ходе судебного разбирательства было установлено, что она, злоупотребляя должностными полномочиями, по уголовным делам, находящимся у нее в производстве, а также некоторым другим делам в течение 2 лет использовала в личных целях большое количество вещественных доказательств: от дорогостоящих бытовых приборов, носимых вещей до автомашины. Однако осудили ее за кражу только одного золотого изделия, которое она похитила из дела другого следователя. В части обвинения по ч. 1 ст. 285 УК РФ гр-ка П. была оправдана только по одной причине - неконкретизированость обвинения. В нем не было указано, какие нормы УПК РФ, какую именно статью, часть, пункт инструкции (по хранению вещественных доказательств) и иные нормативные акты, нарушила гр-ка П. При этом были в наличии все доказательства, касающиеся преступных действий следователя, но отсутствовала полнота обвинения в части указания на нарушение законов и иных НПА.

Следующий этап - редактирование всего постановления. Если текст обвинения большой и сложный, длинные предложения можно и нужно разбить на несколько самостоятельных и более коротких. Кроме того, большие абзацы и иные фрагменты текста целесообразно также разбивать и группировать по смыслу. Это особенно актуально по делам коррупционным и экономическим. Так, например, в первом абзаце содержания обвинения по делу о служебных преступлениях можно привести сведения о том, когда именно, по какому приказу (№ , дата, кто его вынес и т.д.) лицо принято, на какую именно должность. Здесь же, или в следующем абзаце (предложении) следует привести выдержки из законодательства, служебных инструкций, которыми должно было руководствоваться должностное лицо в своей профессиональной деятельности. Как правило, с новой строки подробно описывается, какие именно преступные действия совершило должностное лицо. При этом здесь уже не излагаются подробно наименование и содержание нарушенных лицом норм, поскольку это было сделано в предыдущем тексте. Дается только ссылка на конкретную статью, часть, пункт названного НПА, быть может, даже с заранее оговоренным сокращенным названием этого НПА, без изложения его содержания.

Следует обращать внимание на логику в тексте обвинения. Дурной пример: в обвинении указано, что удары нанесены по лицу, а телесные повреждения почему-то есть и на лице, и на теле или, в худшем варианте, только на теле. Или так: обвиняемый якобы нанес один удар, а телесных повреждений множество. Если данные противоречия не устранить, будет считаться, что обвинение в части конкретных действий или телесных повреждений не будет предъявлено. В обвинении обязательно нужно указать количество действий, например, ударов. Недопустимо применять такие понятия, как «около», «примерно». Если ударов было более чем один, но точно их количество не известно, лучше указать «...нанес множество ударов». Также необходимо указывать, как именно нанесены удары и куда, их локализация и т.д.

Когда в содержании обвинения приводятся выводы из заключений экспертов, например по степени вреда здоровью и другие, недопустимо ссылаться на саму экспертизу, указывая номер документа, дату. Такой описательный прием косвенно придает этому виду доказательств как бы повышенную, заранее установленную силу. В обвинении вообще не приводятся доказательства, это делается в обвинительном заключении. В 2000-2001 гг. в ряде регионов России это привело к массовому направлению уголовных дел для дополнительного расследования (по действовавшему тогда УПК РСФСР).

Если одно из лиц, проходящих по групповому делу, не достигло возраста уголовной ответственности, в обвинении это описывается примерно следующим образом: «Гр. А. ... с гр. Б. ..., в отношении которого уголовное преследование прекращено в связи с тем, что лицо не достигло к моменту совершения преступления возраста уголовной ответственности ...».

Когда в постановлении о привлечении в качестве обвиняемого есть необходимость указать на иностранную валюту, рекомендуем это делать примерно следующим образом: « ... 000 (прописью сумму) долларов США (по курсу Центрального банка РФ на 00.00.00 г. 1 доллар США стоил 000 российских рублей), что составляет на день кражи 000 (прописью сумму) рублей». В обвинении любая сумма (ущерба, хищения и др.) в иностранной валюте должна быть переведена в рубли по курсу Центрального банка РФ на день совершения преступления. 
Многие, составляя обвинение, начинают увлекаться деталями, не имеющими отношения к совершенному преступлению, забывая, в чем именно лицо обвиняется, какое именно преступление оно совершило. При этом, например, излишне описывается, как виновное лицо кудато там ходило, что-то там делало, с кем-то о чем-то разговаривало и т.д. Составляя обвинение, всегда надо задавать себе вопросы: «Лицо обвиняется в этом? Это входит в предмет доказывания (ст. 73 УПК РФ)?» Если нет, то фразу можно безболезненно удалить из текста. Но не забудьте перечитать оставшееся, во избежание нарушения логических, смысловых и иных связей.

Похожая и весьма распространенная ошибка - злоупотребление повторами. Некоторые действительно важные слова и формулировки повторяются по 3-5 раз. К примеру, если речь идет об обвинении в совершении преступления, предусмотренного ст. 228 УК РФ, то порой по несколько раз идет повторение фраз типа: «действуя умышленно», «для личного употребления», «без цели сбыта», «в отношении наркотического средства в особо крупном размере» и т.п. Ненужные повторы идут, начиная с описания момента возникновения умысла и заканчивая задержанием лица. Формально это не нарушение закона. Правда иногда повторы не соответствуют логике, хронологии событий. В любом случае, читать такой текст тяжело. У прокуроров и судей он вызывает раздражение, а это чревато ... В суде такие тексты безжалостно сжимают. Попробуйте отследить «эволюцию» составленного вами текста обвинения по вступившему в силу приговору суда. Увидите, как опытный судья сокращает текст, притом без ущерба для его содержания. Чтобы в тексте обвинения не повторяться во фразах, можно использовать слова «далее»; «потом»; «затем»; «после этого»; «продолжая свои действия»; «во исполнение ...»; «совместными действиями названные лииа»; «тем же ножом»; «на указанной автомашине»; «.. с той же целью»; «ОАО « » (далее - ОАО)» и т.П.

Когда по одному эпизоду проходит несколько обвиняемых, в обвинении конкретного лица вначале принято указывать именно его фамилию, а затем фамилии других обвиняемых. При составлении обвинения на следующее лицо соответственно его фамилия будет первой. Если обвиняемый был условно-досрочно освобожден от наказания, судимость не погашена, в начале обвинения об этом необходимо указать.

Определенную сложность вызывает описание неоконченного преступления - приготовления и покушения, видов соучастников и форм соучастия. Для правильного составления обвинения, например, в части неоконченного преступления, прежде всего необходимо обратиться к ст. 30 УК РФ, где подробно описано, в чем именно проявля- ется приготовление к преступлению и покушение на преступление. Например, фрагмент обвинения по ч. 3 ст. 30 и ч. 2 ст. 167 УК РФ может выглядеть так:

«При этом С. выполнил все необходимые, по его мнению, действия, направленные на умышленное уничтожение путем поджога указанного чужого имущества. Однако по не зависящим от его воли обстоятельствам он не смог довести свой преступный умысел до конца, ввиду того что пожар был потушен силами гр-н К. и М. Только поэтому уничтожения имущества не произошло и причинения значительного ущерба не последовало».

При квалификации действий обвиняемых в соучастии вызывает затруднения описание признаков ст. 33 УК РФ в сочетании с конкретной статьей Особенной части УК РФ. Как вариант, можно описывать примерно так:

«Указанными совместными с гр-нами Ф. и Р. действиями, направленными на пособничество гр-нам Ш. и Г. в убийстве сторожа п/к «Автомобилист» гр-на П., сокрытие трупа последнего при указанных выше обстоятельствах, несовершеннолетний Ш. совершил преступление, предусмотренное ч. 5 ст. 33 и п. «б», «Д», «Ж», «3» ч. 2 ст. 105 УК РФ, соучастие, в форме пособничества в убийстве, то есть в умышленном причинении смерти другому человеку, лица в связи с осуществлением данным лицом служебной деятельности, совершенное с особой жестокостью группой лиц по предварительному сговору, сопряженное с разбоем; выразившееся в содействии совершению преступления советами, предоставлением информации, в обещании заранее скрыть преступника, средства совершения преступления, следы преступления, предметы, добытые преступным путем, в заранее данном обещании сбыть такие предметы...»

Целесообразно после составления проекта обвинения и до его предъявления вернуться к его прочтению через некоторое время. Следует внимательно перепроверить соответствие текста требованиям ст. 171 УПК РФ. Это вызвано тем, что в процессе составления текста у его автора ослабевает внимание. Ошибки легче заметить по прошествии некоторого времени. Традиционно эффективным остается согласование проекта обвинения со своими коллегами, причем не обязательно с вышестоящими. Сосед по кабинету, товарищ-следователь и руководитель органа, скорее всего, увидят те ошибки, которые вы, вероятно,

$\overline{95}$ Не во всех регионах и следственных органах практика описания формулировки обвинения именно такова. 
не заметили. Они также могут высказать свое мнение о квалификации преступлений, компоновке документа, средствах описания и т.д.

Важно проект окончательного обвинения составлять не ближе к окончанию сроков предварительного следствия, а последовательно в ходе него. При заблаговременной подготовке документа видны все недостатки и просчеты расследования, которые еще не поздно будет восполнить.

И последнее. Не забывайте подписывать упомянутое постановление. Это типичная ошибка, когда следователь сначала этому не придает значения, а затем забывает. Надо приучить себя ставить подпись на постановлении сразу после того, как оно распечатано. Важно помнить, что текст обвинения, после его предъявления, не подлежит какой-либо корректировке. Он должен быть слово в слово скопирован в обвинительное заключение.

В данных методических рекомендациях затронута только небольшая часть вопросов, возникающих при составлении обвинения. Надеемся, что рекомендации помогут вам в повседневной деятельности по составлению постановления о привлечении в качестве обвиняемого и других процессуальных документов.

\section{Глава 15}

\section{КАК ПОМОЧЬ В ПРОВЕРКЕ МАТЕРИАЛОВ УГОЛОВНОГО ДЕЛА}

Уважаемый общественный помощник, практикант! В настоящей главе в несколько переработанном и дополненном виде приводится фрагмент учебно-практического издания «Настольная книга помощника судьи», подготовленного коллективом авторов - работников Верховного суда Республики Бурятия ${ }^{96}$. В этой работе любому судье по уголовным делам, а также его помощнику предлагается алгоритм изучения уголовного дела, с помощью которого можно эффективно выявлять возможные нарушения закона и ошибки, часто допускаемые в рамках досудебного производства. Судьи в большинстве своем - самые квалифицированные юристы-практики. Судебный корпус объективен и беспристрастен. Он строг и неумолим в своих выводах по поводу качества предварительного расследования. Потому знать алгоритм выявления тех ошибок, которые в дальнейшем может выявить судья, очень полезно любому представителю стороны обвинения: дознавателю, следователю, руководителю следственного органа, прокурору. Бесспорно, пригодится он и вам - добросовестным помощникам и практикантам. Таким образом, мы предлагаем заняться проверкой, страховкой работы следователя по алгоритму, который чуть позднее будут использовать судьи.

К сожалению, многие следователи начинают проверку дела только к концу расследования (ч. 1 ст. 215 УПК РФ), который часто очень близок к окончанию всех процессуальных сроков, включая сроки содержания обвиняемого под стражей. Это далеко не самый лучший вариант для стороны обвинения. Такую проверку можно сравнить с попыткой студента выучить весь предмет за одну ночь перед экзаменом.

Дело в том, что по истечении названных сроков даже найденные ошибки в большинстве случаев исправить очень трудно. Отдельные нерадивые следователи из-за этого порой идут на фальсификацию документов, в том числе доказательств (пометка «задним числом», запоздалое собирание подписей и т.п.). Некоторых за это увольняют и даже привлекают к уголовной ответственности.

96 Настольная книга помошника судьи: Вып. 1: «Организашия работы и уголовное судопроизводство» / Кол. авт.; под обш. ред. Ю.П. Гармаева и А.О. Хориноева. Улан-Удэ: Республиканская типография, 2008. С. 60-73; Гармаев Ю.П., Хориноев А. О. Алгоритм проверки материалов уголовного дела // Законность. 2009. № 2. С. 16-21. 
Если следователь не устранил все ошибки и нарушения, их обязан выявить руководитель следственного органа (п.П. 2 и 11 ч. 1 ст. 39 УПК РФ). Для следователя, равно как и для всех представителей стороны обвинения, выявление дефектов на этих стадиях - далеко не лучший вариант. Здесь последствиями существенных нарушений закона и ошибок могут быть: прекращение уголовного дела и уголовного преследования, возвращение дела для производства дополнительного следствия или пересоставления обвинительного заключения (п.П. 6 и 11 ч. 1 ст. 39 УПК РФ), наряду с дисциплинарными взысканиями и другими неблагоприятными последствиями.

Несколько иная ситуация и задачи у надзирающего прокурора и государственного обвинителя. Им дело поступает уже с обвинительным заключением и что-либо исправить, как правило, удается только путем возвращения дела ${ }^{97}$. Но ведь лучше выбрать меньшее из зол - вовремя вернуть дело следователю, чем возврат от судьи в порядке ст. 237 УПК РФ или самое худшее - оправдательный приговор.

Вывод прост: проверять дело по нижеизложенной программе нужно задолго до окончания следствия ${ }^{98}$

И вот тут-то, уважаемые помощники, практиканты, вы можете оказать правоприменителям неоценимую помощь! Следователь, дознаватель, прокурор сильно заняты - пусть так! Возьмите предварительную проверку на себя. Всего-то нужно положить перед собой дело, УК РФ и УПК РФ, настоящее пособие, чистый лист бумаги. Следственная практика и практика прокурорского надзора показывает, что за два-три часа изучения дела даже неопытный юрист может найти от 5 до 50 мелких и существенных ошибок и даже нарушений закона. Сделав выписки, покажите свою аналитическую справку следователю, и вы увидите, как он будет вам благодарен, даже если не со всеми ошибками согласится.

Вот как, к примеру, может выглядеть одна из ваших записей об обнаруженной ошибке:

«Том №__, л. д. (лист дела) № __; документ - постановление (протокол и т.п.); ошибка - нет подписи следователя__ (нет ссылки на закон, нарушено право на защиту и др.); какие нормы тем самым нарушены: (статья УПК РФ, УК РФ и др.).

${ }_{97}^{97}$ К сожалению, в силу низкой профессиональной квалификации значительной части следователей широко распространена практика непроцессуального возвращения дела. Бывает так, что в районах в порядке п. 11 ч. 1 ст. 39 УПК РФ или п. 3 ч. 1 ст. 221 УПК РФ возвращается 2-3 дела в год, а в непроцессуальном порядке, «на доработку» - каждое второе дело и более.

98 Лучше всего, конечно, вовсе не допускать ошибок, но такого в следственной практике, $\mathrm{K}$ сожалению, почти не бывает. Задача - свести существенные нарушения закона и ошибки до минимума, вовремя их выявлять и устранять.
Можете составить справку в виде таблицы - как вам удобно и как порекомендует следователь. Некоторые правоприменители используют бумажные закладки (стикеры) с записями, вставляемые к соответствующим листам уголовного дела. Это действительно иногда удобно. Только размер прямоугольника бумаги должен соответствовать задаче, а на самих листах дела ни в коем случае не должны оставаться какие-либо пометки. Предупреждаем: не всегда такой метод представления отчета об изучении дела удобен. Особенно если дело многотомное, сложное, а выявленных нарушений и ошибок довольно много. Но как бы не были оформлены выводы, очевидно одно - вы и следователю поможете очень существенно, и сами научитесь не допускать нарушений закона.

Проверка дела по частям алгоритма (с 1 по 7) может производится:

- в предложенной последовательности. Но это только в случае, когда дело закончено производством и обвинительное заключение уже составлено;

- в случае, когда дело еще не окончено производством, можно проверять дело от части 2 и до 7 алгоритма, а затем по части 1;

- некоторым легче изучать дело по хронологии составления и порядку систематизации (подшивки) документов, то есть как простую книгу. Тогда рекомендуем использовать такой алгоритм: ч. 2 (проверим сначала обвинение), затем части 4-7, затем части 3 и 1;

- лучше всего посоветоваться с курирующим следователем, показав ему этот текст.

Итак, умение квалифицированно, тщательно и вместе с тем оперативно изучить, проверить дело и довести до сведения правоприменителя собственное мнение по целому ряду важных вопросов - один из основных критериев профессионализма юриста, залог его успешного трудоустройства и удачной карьеры.

\section{Примерный алгоритм изучения и анализа материалов уголовного дела судьей и его помощником ${ }^{99}$}

Сразу при поступлении дела помощнику, вслед за судьей, надлежит проверить, подсудно ли уголовное дело суду, а также соблюдены ли сроки предварительного расследования, и что особенно важно - сроки

\footnotetext{
9 Этот алгоритм можно скачать на сайте labatr.bsu.ru, ссылка на данное руководство, электронное приложение № 14.
} 
содержания обвиняемого под стражей; достаточны ли они для дальнейшего рассмотрения дела; утверждено ли в течение 10 дней обвинительное заключение (ч. 1 ст. 221 УПК РФ) $)^{100}$.

\section{Часть 1. Изучение обвинительного заключения ${ }^{101}$}

Более тщательное изучение материалов дела в суде первой инстанции начинается, как правило, с обвинительного заключения.

1.1. Приступая к его изучению, необходимо убедиться в том, что оно (а также приложения к нему) подписано следователем (дознавателем) и утверждено прокурором; следует тщательно проверить, составлено ли обвинительное заключение в соответствии с требованиями ст. 220 УПК РФ. В частности:

1.2. Указана ли дата и место составления

1.3. Оформлены ли приложения:

1.3.1. Список лиц, подлежащих вызову в судебное заседание, как со стороны обвинения, так и со стороны защиты, с указанием их места жительства и (или) места нахождения;

1.3.2. Справка о сроках следствия, об избранных мерах пресечения с указанием времени содержания под стражей и домашнего ареста; вещественных доказательствах; гражданском иске и о принятых мерах по его обеспечению и возможной конфискации имущества; процессуальных издержках; при наличии у обвиняемого, потерпевшего иждивенцев - о принятых мерах по обеспечению их прав.

В справке должны быть ссылки на соответствующие листы дела.

1.4. Переведены ли обвинительное заключение, иные процессуальные документы для обвиняемого, не владеющего или не достаточно владеющего русским языком на родной язык или на язык, которым он владеет.

1.5. Обратить особое внимание на соответствие обвинения, изложенного в постановлении о привлечении в качестве обвиняемого, тексту обвинительного заключения.

${ }^{100}$ После составления обвинительного заключения выяснить это можно на основе справки по делу (ч. 5 ст. 220 УПК РФ). Но следователям и их помощникам настоятельно рекомендуется начать изучать дело раньше. Поэтому следует посмотреть конкретные документы, отражающие соответствующие правовые решения: постановление о возбуждении уголовного дела, об избрании (продлении) меры пресечения и др.

${ }^{101}$ С обвинительного заключения начинают проверку дела не только судья, но и руководитель СО, прокурор. Однако, как уже отмечалось, следователь и его помощник первую проверку начинают намного раньше - когда расследование еще не окончено. В этом случае начинаем проверку с части 2 .
1.6. Изложено ли обвинение полностью; указаны ли полностью и в точном соответствии с законом пункты, части и статьи УК РФ $\Phi^{102}$.

1.7. Не относится ли обвиняемый к одной из категорий лиц, в отношении которых применяется особый порядок производства по уголовным делам (гл. 52 УПК РФ), соблюден ли этот порядок органами предварительного расследования.

1.8. Приведены ли в обвинительном заключении иные данные о личности обвиняемого (обвиняемых), в том числе: состав семьи, сведения о прошлых судимостях, данные о месте его нахождения; имеются ли данные о потерпевшем. Соответствуют ли эти сведения другим документам уголовного дела.

1.9. Правильно ли в обвинительном заключении указаны данные о личности обвиняемого, потерпевшего (в соответствии с документами, удостоверяющими личность), сведения о характере и размере вреда.

1.10. Приведен ли перечень доказательств обвинения и защиты, дано ли краткое описание каждого доказательства; имеются ли при каждом из них ссылки на тома и листы дела, точны ли они.

1.11. Приведены ли доказательства по каждому обвиняемому.

1.12. Указаны ли отягчающие и смягчающие наказание обстоятельства.

1.13. Полно ли составлен список лиц, подлежащих вызову в судебное заседание, в том числе данные об обвиняемом, его законном представителе, адвокате-защитнике, а также о потерпевшем, его законном представителе, адвокате-представителе и т.д.

\section{Часть 2. Изучение предъявленного обвинения}

В соответствии со ст. 171 УПК РФ постановление о привлечении в качестве обвиняемого следует проверить по следующим вопросам:

2.1. Правильно ли написана фамилия, имя, отчество обвиняемого, время и место его рождения.

2.2. Правильно ли описано событие преступления с указанием места, времени его совершения, а также других обстоятельств, подлежащих доказыванию в соответствии с пунктами 1-4 части первой статьи 73 УПК РФ.

2.3. Описаны ли конкретные действия обвиняемого по каждому эпизоду; дана ли квалификация содеянного отдельно по каждому из них. 102 Дополнительно об алгоритме составления и соответственно проверки постановления
о привлечении в качестве обвиняемого см. гл. 14 и часть 2 алгоритма. 
2.4. Обоснована ли виновность лица, форма его вины и мотивы совершения преступления ${ }^{103}$.

2.5. Соответствует ли формула и формулировка ${ }^{104}$ обвинения диспозиции соответствующей статьи (статей) УК РФ, включая нормы Общей части УК (ст.ст. 30, 33 и др.).

2.6. Нет ли ошибки в квалификации преступлений, включая квалифицирующие признаки ${ }^{105}$.

2.7. Взаимосвязаны ли формулы и формулировки обвинения соучастников преступления; нет ли противоречий в содержании предъявленных им обвинений.

2.8. Нет ли совокупности преступлений, требующей дополнительной квалификации.

2.9. Описаны ли последствия преступлений, характеристики причиненного вреда и другие обстоятельства. Например, по ст.ст. 285-286, 288, ч. 2 ст. 292, ч. 1 ст. 293 УК РФ следователи часто не «расписывают» подробно в обвинении характеристику существенного нарушения прав и законных интересов граждан или организаций либо охраняемых законом интересов общества или государства.

2.10. Не допущено ли нарушение сроков предъявления обвинения.

2.11. Подписано ли следователем постановление, указаны ли дата и место его составления.

\section{Часть 3. Проверка соблюдения права на защиту}

3.1. Был ли обеспечен подозреваемый, обвиняемый помощью адвоката-зашитника во всех предусмотренных законом случаях, в том числе в случаях обязательного участия защитника (ст. 51 УПК РФ).

3.2. Не предъявлено ли обвинение в отсутствие адвоката-защитника, с которым у обвиняемого было заключено соглашение.

3.3. Не допускалось ли участие на следствии одного адвоката в качестве защитника двух обвиняемых, между показаниями которых имелись противоречия

${ }^{103}$ А также в зависимости от конструкции состава вменяемого ему преступления, цель и эмоциональное состояние в момент его совершения.

104 Значение этих и других специальных терминов, имеющих отношение к содержанию обвинения, см. гл. 14

105 При решении этого, одного из самых сложных правовых вопросов, кроме прочего, следует в обязательном порядке обращаться к разъяснениям Пленума Верховного суда РФ и СССР, а также к иной опубликованной судебной практике.
3.4. Не производилась ли необоснованная замена адвокатов, допущенных в дело; отказывался ли официально обвиняемый от защитника после назначения ему новых.

3.5. Выяснено ли состояние здоровья обвиняемого, состояние его психики.

3.6. Был ли обвиняемый, имеющий физические и психические недостатки, обеспечен защитником.

3.7. Не допускалось ли в качестве защитника лицо, у которого истекли полномочия адвоката.

3.8. Переведены ли обвиняемому, не владеющему языком судопроизводства, основные процессуальные документы по делу.

3.9. Имеются ли на всех листах допросов подозреваемого, обвиняемого, не владеющего языком судопроизводства, подписи переводчика.

3.10. Выяснено ли у обвиняемого его возможное алиби, проверено ли оно.

3.11. Выяснено ли у него, какие доказательства, опровергающие обвинение, он может представлять.

3.12. Допрошен ли он в полном объеме предъявленного обвинения, в том числе по вопросам вины, мотивам, квалифицирующим и привилегированным признакам вменяемого преступления.

3.13. Допрошен ли он по смягчающим и отягчающим наказание обстоятельствам.

3.14. При частичном признании своей вины отражено ли в протоколе допроса то, в чем обвиняемый признает себя виновным, а в чем не признает.

3.15. Ознакомлен ли он с постановлениями о назначении экспертиз, с их заключениями и протоколом допроса эксперта.

3.16. Разрешены ли ходатайства, заявленные им в ходе следствия.

3.17. Указаны ли в протоколе ознакомления обвиняемого и его защитника дата и время начала и окончания ознакомления.

3.18. В случае раздельного ознакомления с материалами дела имеется ли заявление обвиняемого с просьбой о раздельном ознакомлении; имеется ли постановление следователя об отказе или удовлетворении данного ходатайства.

3.19. Имеется ли в протоколе ознакомления сведения о том, ознакомлен ли обвиняемый и его адвокат с материалами дела, в полном ли объеме, заявлены ли ими ходатайства.

3.21. Разрешены ли ходатайства обвиняемого и его защитника.

3.22. Приобщены ли уведомления.

3.23. Не нарушены ли требования ч. 5 ст. 217 УПК РФ, в том числе. 
3.24. Разъяснено ли обвиняемому право ходатайствовать о рассмотрении уголовного дела судом с участием присяжных заседателей.

3.25. Разъяснены ли обвиняемому особенности рассмотрения дела судом с участием присяжных заседателей, в том числе права обвиняемого в судебном разбирательстве и порядок обжалования судебного решения (как правило, составляется отдельный протокол разъяснения прав).

3.26. Разъяснена ли обвиняемому, не заявившему ходатайства о рассмотрении уголовного дела судом присяжных, возможность выделения в отношении него уголовного дела в отдельное производство.

3.27. Какие именно вешественные доказательства и иные предметы представлены для ознакомления, каким образом проводилось ознакомление (раздельно или совместно с защитником).

\section{Часть 4. Другие процессуальные критерии проверки материалов уголовного дела}

4.1. Надлежащим ли лицом возбуждено уголовное дело.

4.2. Не нарушена ли подследственность, в том числе в отношении военнослужащих.

4.3. Вынесены ли, подписаны ли все необходимые постановления, в частности:

4.3.1. О возбуждении уголовного дела и принятии его к производству;

4.3.2. О принятии уголовного дела к производству ${ }^{106}$;

4.3.3. Об избрании (изменении, отмене) мер пресечения;

4.3.4. О признании потерпевшим;

4.3.5. О признании гражданским истцом;

4.3.6. О признании гражданским ответчиком;

4.3.7. О соединении дел;

4.3.8. О выделении материалов;

4.3.9. О прекращении дела в отношении отдельных лиц или отдельных эпизодов;

4.3.10. О б изменении обвинения и др.

4.4. Объявлены ли постановления участникам процесса в предусмотренных законом случаях, имеются ли соответствующие подписи.

4.5. Составлены ли процессуальные документы в соответствии с требованиями УПК РФ, в частности:

4.5.1. Указаны ли дата и время, место их составления;

4.5.2. Имеются ли все необходимые подписи;

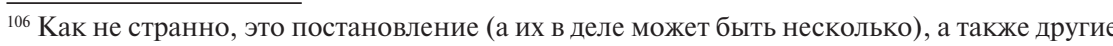
документы следователи часто забывают подписать.
4.5.3. Оговорены ли имеющиеся исправления;

4.5.4. Заверены ли должным образом копии документов.

4.6. Вынесены ли постановления о признании и приобщении к делу вещественных доказательств.

4.7. Приложены ли к делу документы, свидетельствующие о том, куда сданы, где хранятся деньги, ценности, вещественные доказательства.

4.8. Приложены ли документы о процессуальных издержках по делу.

4.9. Нет ли ошибок в нумерации листов дела.

4.10. Правильно ли составлена опись документов, нет ли расхождений в нумерации между описью и самим делом.

4.11. Ознакомлен ли потерпевший с материалами дела; если нет, приобщено ли уведомление в его адрес об окончании следственных действий и его праве ознакомления с материалами дела (дата вручения и подпись потерпевшего на уведомлении) либо документы о невозможности его уведомления.

4.12. Разрешены ли ходатайства потерпевшего.

4.13. Вручены ли копии обвинительного заключения.

4.14. Нет ли обстоятельств, влекущих прекращение либо приостановление производства по делу.

4.15. Собраны ли доказательства, достаточные для рассмотрения дела в судебном заседании.

4.16. Подлежит ли изменению или отмене избранная обвиняемому мера пресечения.

4.17. Приняты ли меры, обеспечивающие возмещение материального ущерба, причиненного преступлением.

\section{Часть 5. Другие криминалистические критерии проверки материалов уголовного дела}

5.1. Надлежащим ли образом осмотрено место происшествия.

5.2. Проверены ли все выдвинутые и подлежавшие выдвижению версии, в том числе версии защиты.

5.3. Допускался ли отказ в удовлетворении ходатайства адвоката о проведении следственных действий, вследствие чего не были проверены все доказательства.

5.4. Установлены ли все соучастники, роль каждого из них.

5.5. Нет ли данных о совершении обвиняемым других преступлений, проверены ли эти данные.

5.6. Допрошены ли все упомянутые в протоколах, рапортах, объяснениях. 
5.7. Проведены ли все необходимые:

5.7.1. Осмотры;

5.7.2. Освидетельствования;

5.7.3. Обыски;

5.7.4. Выемки;

5.7.5. Следственные эксперименты;

5.7.6. Проверки показаний на месте.

5.8. Все ли необходимые экспертизы проведены.

5.9. Поставлены ли на разрешение экспертов все требуемые вопросы.

5.10. Даны ли в заключениях экспертиз ответы на все поставленные вопросы.

5.11. Нет ли необходимости допросить эксперта (специалиста), провести повторную, дополнительную экспертизу.

5.12. Приложены ли к заключению эксперта необходимые материалы.

5.13. Посланы ли необходимые запросы, отдельные поручения, даны ли необходимые поручения органам дознания.

5.14. Получены ли ответы.

5.15. Не остались ли в деле документы, которые надлежит хранить не в деле, например, в надзорном производстве (планы расследования, планы ОРМ, схемы преступных связей и прочее).

5.16. Имеются ли в наличии все вещественные доказательства, документы, ценности, указанные в протоколах, как изъятые.

5.17. Взяты ли из экспертных учреждений вещественные доказательства.

5.18. Определена ли судьба не имеющих отношения к делу личных вешей и документов, изъятых у подозреваемого, обвиняемого, иных лиц.

5.19. Изготовлены ли к протоколам схемы, фототаблицы, негативы (в случае необходимости).

5.20. Правильно ли сгруппированы материалы дела ${ }^{107}$.

\section{Часть 6. Вопросы прекращения уголовного дела или уголовного преследования}

6.1. Имеется ли действуюший акт амнистии и если да, то применим ли он к обвиняемым по делу.

6.2. Нет ли в деле неотмененного постановления о прекращении дела по тому же обвинению, что предъявлено, либо соответствующего постановления об отказе в возбуждении уголовного дела.
6.3. Не истекли ли сроки давности привлечения к уголовной ответственности.

6.4. Имеется ли в деле заключение суда о наличии признаков преступления в действиях некоторых категории лиц, в отношении которых применяется особый порядок производства по уголовным делам (ст.ст. 447-448 УПК РФ) ${ }^{108}$.

\section{Часть 7. Вопросы возвращения дела прокурору в порядке ст. 237 УПК РФ}

Речь идет об одном из самых неприятных для стороны обвинения последствий нарушений закона в рамках досудебного производства. Хуже, как правило, только оправдательный приговор. Поэтому и общественному помощнику (практиканту), и следователю, и руководителю следственного органа, и надзирающему прокурору с его гособвинителем предлагаем при изучении дела мысленно встать на место судьи и заранее проверить, не допущены ли следующие обстоятельства, указанные в ч. 1 ст. 237 УПК РФ:

7.1. Обвинительное заключение составлено с нарушением требований УПК РФ, что исключает возможность вынесения судом приговора или иного судебного решения (см. часть 1 алгоритма).

7.2. Копия обвинительного заключения не была вручена обвиняемому. При этом необходимо иметь в виду, что при отказе обвиняемого от получения копии обвинительного заключения путем неявки по вызову или иным образом прокурор в соответствии с ч. 4 ст. 222 УПК РФ может направить дело в суд с указанием причин невручения копии обвинительного заключения.

7.3. Есть необходимость составления обвинительного заключения по делу, направленному в суд с постановлением о применении принудительной меры медицинского характера.

7.4. Имеются основания для соединения дел.

7.5. При ознакомлении обвиняемого с материалами дела ему не были разъяснены права, предусмотренные ч. 5 ст. 217 УПК РФ. 


\section{Глава 16}

\section{УЧЕБНАЯ ПРАКТИКА СТУДЕНТА, КУРСОВЫЕ, ДИПЛОМНАЯ РАБОТА КАК ЭТАПЫ ПРОФЕССИОНАЛЬНОЙ СТРАТЕГИИ УСПЕШНОГО ЮРИСТА (вместо Послесловия)}

Эта глава написана как бы «вдогонку», уже после окончания работы над «Руководством...», и в его стилистические рамки она явно не вписывается - это, скорее, Послесловие! Здесь авторам хотелось бы высказаться, быть может, по самому важному - стратегическому вопросу, вопросу мотивации и целеполагания студента-практиканта и общественного помощника. Перед ним, как человеком практичным, обязательно встанет вопрос: а зачем так серьезно и основательно относиться к производственной (ознакомительной, преддипломной) практике, а тем более становиться добровольно и бесплатно общественным помощником следователя? Ведь это громадные затраты времени и сил умного, энергичного и притом весьма занятого молодого человека! Пожалуй, здесь нужны особые пояснения.

Как верно отмечено в Предисловии Указ Президента РФ от 26.05.2009 № 599 «О мерах по совершенствованию высшего юридического образования в Российской Федерации» вновь напомнил юридическому сообществу о необходимости «...увеличения объема практической части основной образовательной программы высшего профессионального образования...» Научная обшественность давно бьет тревогу по поводу катастрофического снижения качества обучения. Так, прав А.С. Подшибякин, говоря о том, что в юридическом образовании нарушается системность, которая должна обеспечиваться четкой структурно-логической схемой прохождения учебных дисциплин, базирующейся на четкой системе права ${ }^{109}$.

Итак, практически во всех вузах страны имеются проблемы, связанные с явно недостаточным вниманием к вопросам деятельности студентов, в том числе общественных помощников, в рамках прохождения практики и использования ее результатов в учебной и научной работе. Эта тенденция порождает ряд весьма неблагоприятных последствий.

109 Подшибякин А.С. О проблемах юридического образования (мнимых и реальных) // Юридическое образование и наука. 2008. № 4. С. 15.
Работодатели всей страны (суды, прокуратура, органы МВД, министерства юстиции и другие) часто отмечают, что рядовой выпускник любого юридического вуза страны, приступая к работе по специальности, чаще всего, имеет лишь самые общие представления о реальной практике работы организации-работодателя, корпоративной политике и этике, документообороте. Выпускник-юрист зачастую испытывает затруднения в самых необходимых прикладных знаниях и навыках: как вести деловую переписку, составить протокол, постановление, приговор или иной правоприменительный акт; как помочь гражданам подготовить необходимые им документы, защищая их права; как оптимальным путем пройти официальные процедуры, преодолеть бюрократические препоны.

Только послевузовский, часто многолетний опыт работы позволяет молодому юристу сократить значительный разрыв между теорией и практикой. По принципу маятника через несколько лет бывший выпускник ощущает уже другой дисбаланс, когда не основанная на законе практика (а это очень распространено в России) вступает в противоречие с теорией. И тогда победа первой становится почти нормой и приводит к систематическим нарушениям прав и законных интересов граждан, общества и государства.

Нельзя сказать, что действующие в России образовательные технологии в области юриспруденции совершенно игнорируют практическую составляюшую обучения. Так, образовательный процесс в лучших юридических вузах всегда опирался и опирается на эффективное применение ознакомительной, производственной, преддипломной практики, прикладных, в том числе игровых методов обучения ${ }^{10}$, работу юридических клиник и кружков. Активно используются компьютерные классы и электронные библиотеки, в них размещены такие справочные правовые системы, как «Консультант Плюс», «Гарант» и другие (далее - СПС). Эти дидактические средства в определенной мере устраняют имеюшийся дисбаланс между теоретической и прикладной составляющей обучения. Тем не менее общероссийская тенденция такова: вузовские образовательные технологии сильны своими теоретическими и методическими составляющими, но несколько оторваны от практики.

В целях корректировки этого перекоса в системе высшего юридического образования в ряде юридических вузов в учебный процесс 110 Так, в ряде вузов, в том числе в тех, где работают авторы этих строк, по многим предметам
проводятся деловые игры, имитирующие состязательный процесс в судах; на семинарах
используются реальные, то есть «на бумаге» уголовные и гражданские дела прошлых лет;
проводятся спецкурсы по методике составления процессуальных документов и т.п. 
внедряется уникальная инновационная, практически ориентированная технология обучения будущих и действующих юристов. Сущностью разработки, системообразующим ядром предлагаемой технологии обучения является создание, постоянное пополнение и совершенствование мультимедийной информационной обучающая системы (далее - информационная система или МИОС). Она развивается на основе уже сформированной и постоянно модернизируемой электронной базы данных правоприменительной (судебной и иной) практики по гражданским и уголовным делам регионов Сибири, Дальнего Востока и всей России.

Информационная система в настоящий момент занимает более 2 ГБ и включает свыше 300000 реальных правоприменительных актов по конкретным делам: приговоров, иных решений судов, обвинительных заключений, постановлений, протоколов, а также методических материалов: памяток, комментариев, алгоритмов, программ, подготовленных судами, прокуратурами и другими правоохранительными органами всей страны по реальным делам ${ }^{111}$.

При этом МИОС постоянно расширяется как по количеству имеющихся документов и методических рекомендаций по их применению, так и в направлении увеличения числа охватываемых отраслей права. Безусловно, само по себе накопление информации и расширение МИОС является не целью, а средством, условием продвижения инновационной образовательной технологии. Основное ее содержание это система оригинальных методов обучения юристов.

В наиболее общем плане сущность этих инновационных технологий заключается в том, что при проведении лекционных, практических и иных занятий обучение осуществляется посредством анализа и обработки студентами электронных (мультимедийных) копий отдельных документов и полных материалов реальных уголовных, гражданских и иных дел (подборок документов по правилам, действующим на практике), специфическим образом отредактированных, обезличенных, снабженных тестами и иными заданиями, адаптированными для различных задач образовательной технологии. Студенты изучают эти реальные документы и дела, а затем:

- выполняют задания, связанные с прогнозированием, предупреждением, выявлением и устранением типичных ошибок и нарушений закона со стороны правоприменителей;

11 Электронные приложения к данному руководству, размещенные на сайте labatr.bsu.ru, являются частью МИОС. Автор разработки - Ю. П. Гармаев.
- готовят собственные варианты документов на основе дополнительной, измененной или уточненной преподавателем информации;

- организуют и проводят деловые игры, имитирующие практические ситуации, судебные процессы, иные процедуры, и др. ${ }^{112}$

Как одно из составляющих инновационной технологии обучения, рассмотрим особенности процесса подготовки курсовых и дипломных работ студентами-юристами.

Как известно, одной из основных задач их написания является проверка уровня освоения практических навыков, умения работать не только с нормативно-правовыми актами, специальной литературой, статистическими и иными источниками, но и с материалами следственной, судебной практики по уголовным делам, практики работы в гражданском, административном, конституционным и ином судопроизводстве.

В каждом юридическом вузе имеются методические пособия по написанию дипломных и курсовых работ. В них комплексно рассматриваются все вопросы: от выбора темы и составления плана до процедуры защиты ${ }^{113}$. Изучение таких работ показало, что в них большое внимание уделяется особенностям работы студента со специальной литературой и законодательством. В целом такой подход следует признать традиционным и проверенным. Но все же в большинстве изданий необоснованно мало внимания уделяется тому, как студент может и должен использовать результаты пройденных им практик, а также работы постоянным общественным помощником в той или иной организации.

К сожалению, очень часто приходиться видеть примеры того, как студент, даже весьма способный, из года в год произвольно, как-то хаотично, выбирает темы курсовых. Затем на пятом курсе он определяет тему дипломного сочинения, никак не связанную ни с ранее проделанной работой, ни с будущей профессиональной деятельностью. Очень часто и прохождение практик проходит в режиме «удовлетворения общего любопытства», а не ради углубленного изучения будущей профессии. В итоге к окончанию вуза при таком подходе к практике и квалификационным работам студент, не будучи мотивированным и подготовленным к конкретному виду профессиональной деятельности, имея даже диплом с отличием, не может найти себе работу. В лучшем случае такой выпускник трудоустраивается туда, где возьмут без стажа... Во многом поэтому

\footnotetext{
$\overline{112}$ Более подробно о сущности и особенностях применения МИОС см. на сайте labatr.bsu. $\mathrm{ru}$, электронные приложения к данному пособию, папка «Методические материалы».

${ }^{113}$ Пособия на эту тему, изданные в САПЭУ и БГУ, можно скачать на сайте labatr.bsu.ru, электронные приложения к данному пособию, папка «Методические материалы».
} 
не приходится удивляться выводам о низком качестве юридического образования при избытке юристов и недостатке профессионалов ${ }^{114}$.

По нашему мнению студент, приступая к написанию курсовой и дипломной работы, должен:

1. Определить для себя приоритетное направление углубленного изучения и исследования проблемы в той или иной отрасли права, те вопросы, которые в большей степени актуальны и могут быть впоследствии использованы им в его дальнейшей практической либо научно-исследовательской деятельности. Мы убеждены, что студент-юрист, максимум, на третьем курсе должен иметь более или менее четкие и реалистичные суждения не просто по поводу своей специализации (уголовно-правовая, гражданско-правовая, конституционно-правовая и т.д.), а также по поводу:

- конкретного места работы;

- должности, которую он хотел бы занимать;

- основных направлений профессионального и карьерного роста.

2. Выбрать тему курсовой, а далее дипломной работы с учетом будущего вероятного трудоустройства, того, как правило, достаточно узкого направления правоприменительной деятельности (юридической науки), которому будущий юрист собирается себя посвятить. Прежде всего тема должна быть интересна самому студенту, а не кафедре, конкретному преподавателю и т.п. И в то же время она должна быть актуальна и практически значима ${ }^{115}$. Интерес к выбранной теме должен сформироваться, прежде всего, именно в результате прохождения практики или работы общественным помощником.

3. Выбрать преподавателя, который будет осуществлять руководство написанием курсовой и дипломной работы. Выбор научного руководителя должен производиться исходя из выбранной тематики и того, в какой области научной и/или практической деятельности специализируется преподаватель. Как известно, особенность современного юридического образования такова, что многие преподаватели одновременно являются правоприменителями: адвокатами, судьями, юристами на предприятиях и т.д. По возможности следует выбирать такого руководителя, который имеет опыт в практической деятельности, относящейся к тематике курсовой, дипломной работы.

\footnotetext{
114 Заседание правления ассоциации юристов России (редакционный материал) // Юри дический мир. 2006. № 12. С. 6.

115 Это не исключает и не принижает значения тем, имеющих теоретическую значимость, особенно для студентов, решивших в дальнейшем посвятить себя научной деятельности.
}

4. Выбрать себе консультанта (консультантов) из числа практических работников. План курсовой, дипломной работы, направления исследования и его результаты рекомендуется обсудить не только с руководителем (преподавателем), но и по возможности с кем-либо из правоприменителей в данной конкретной сфере деятельности.

Уважаемый студент! У вас до сих пор нет деловых знакомств с действующими следователями, прокурорами, адвокатами, судьями, другими практикующими юристами? Напрасно - пора заводить! Студент, начиная примерно со второго, третьего курса, может и должен иметь собственные деловые связи. Они пригодятся в любом случае. Используйте эти знакомства, например, следующим образом:

- получайте у практиков копии реальных документов;

- согласовывайте с ними ваши доводы и решения;

- уточняйте, как бы судья (прокурор, адвокат и др.) вашего города, района поступил бы в той или иной сложной ситуации. Помните, в

России у каждого региона, а порой и города, района есть свои особенности правоприменительной практики;

- показывайте им для проверки фрагменты или весь текст своего сочинения. Просите сделать замечания и внести поправки.

Именно этим вы обеспечите себе и отличные знания, и хороший практический опыт, и важные связи для будущего успешного трудоустройства.

5. Составить примерные списки нормативно-правовых актов, литературы, судебной и иной правоприменительной практики, планируемой к изучению и исследованию в процессе написания курсовой и дипломной работы.

Остановимся поподробнее на последнем элементе перечня. В соответствующих учебных пособиях рекомендации по поиску, получению и использованию студентами актов применения права обычно либо отсутствуют, либо бывают весьма скудными, неконкретизированными.

Правоприменительная практика делится на опубликованную в открытой печати и неопубликованную. К первой относятся акты применения права, приведенные в бюллетенях Верховного суда РФ, в электронных СПС типа «Консультант Плюс», в книгах, журналах, газетах, на специальных сайтах в Интернете, например: официальных сайтах судов, прокуратур и следственных органов субъектов РФ, сайтах адвокатских палат и адвокатских образований и мн. др. С каждым днем таких сайтов и документов становиться все больше.

Неопубликованная правоприменительная практика преимущественно находиться в производстве или в архивах судебных, правоохранительных и других органов, учреждений. 
В отдельных вузах сложилась практика, которую, на наш взгляд, стоит поощрять. В них обязательным требованием к содержанию дипломного сочинения является анализ не только общероссийской, но и, как правило, местной правоприменительной практики. Этот анализ может выражаться не только в приведении статистических данных, аналитических материалов, но и примеров по конкретным гражданским, уголовным и иным делам. Разумеется, речь идет в основном о практике неопубликованной. К дипломным сочинениям может прилагаться обезличенные материалы из уголовных дел, законченных производством. При таком подходе перед студентом возникает серьезная задача: где найти такие материалы и как получить найденное?

Попробуем ответить на этот вопрос. Так, например, по уголовноправовой специализации студент, именно находясь на практике, может получить доступ к неопубликованным правоприменительным документам в следующих местах:

1. В архиве суда. Если вы проходите практику в суде, то там можно попробовать получить подшитое и пронумерованное дело с описью и вступившим в законную силу правовым решением. Дело завершено производством полностью. При наличии разрешения председателя суда и технической возможности из него можно скопировать (сканировать, сфотографировать, перепечатать) необходимые документы. Но в архиве нет наиболее удобных для студентов электронных копий. Придется работать с оригиналами документов, то есть с «бумагой». Это нелегко. Да и на вынос дело никто не даст. Можно посмотреть, какой следователь расследовал дело; кто из судей его рассматривал; какой прокурор утвердил обвинительное заключение; кто поддерживал обвинение в суде; кто из адвокатов защищал (на следствии, в суде). У этих лиц могут быть и электронные, и «бумажные» копии отдельных документов из этого дела. Электронных файлов больше всего у следователя и адвоката-защитника.

2. У следователя, дознавателя. Полностью подшитое и пронумерованное дело с описью может находиться у следователя только в тот период времени, когда он закончил расследование, знакомит с делом участников судопроизводства и составляет обвинительное заключение (ст.ст. 215-220 УПК РФ). Этот период составляет всего несколько дней. До этого дело находится в производстве следователя, расследование не завершено, материалы могут быть не подшиты или подшиты «в черновую». В ходе расследования часто действует режим охраняемой законом тайны предварительного расследования (ст. 161 УПК РФ) ${ }^{116}$. Как известно любому юристу,

$\overline{116}$ Что есть тайна, а что нет, решает сам следователь, прокурор, дознаватель (ч. 3 ст. 161 УПК РФ) за ее разглашение предусмотрена уголовная ответственность (ст. 310 УК РФ). Поэтому изучать такие материалы не всегда разрешено, да чаще и не нужно, во-первых, во избежание нарушения закона, во-вторых, не стоит забывать, что правового решения по делу еще нет.

После выполнения требований ст. 220 УПК РФ у следователя «бумажного» дела нет. Но, как уже отмечалось, абсолютное большинство следователей и дознавателей составляет часть процессуальных документов в виде электронных файлов в памяти компьютера. В базах данных конкретного следователя накапливаются тысячи электронных документов, как правило, сгруппированных по номерам законченных им уголовных дел ${ }^{117}$. Постановления, обвинительные заключения (обвинительные акты), представления практически всегда есть в электронном виде. В настоящее время все большее количество следователей даже протоколы следственных действий (допросов, осмотров и др.) составляет на компьютере. Это один из признаков его профессионализма.

3. Унадзирающего прокурора, государственного обвинителя. В прокуратуре хранится надзорное производство (НП) по каждому уголовному делу. На период расследования оно находится в канцелярии или у заместителя, помощника прокурора по надзору за следствием и дознанием. На судебных стадиях эта часто уже весьма объемная папка временно хранится у государственного обвинителя. Он ходит с ней на процесс по делу. После его рассмотрения НП хранится в канцелярии или архиве прокуратуры. В НП хранятся ключевые документы по конкретному делу. Это обвинительное заключение, постановления, уведомления, другие процессуальные документы. У государственного обвинителя вряд ли останутся какие-либо электронные варианты документов дела, разве что его речь в прениях. В прокуратуре хранятся также прекращенные, приостановленные дела. Электронные копии таких дел хранятся у следователя, принявшего соответствующее решение.

4. У адвоката-зашитника. У этого участника уголовного судопроизводства материалы уголовных дел могут храниться в виде электронных или «бумажных» копий практически в полном объеме. По крайней мере, документы предварительного расследования. Ведь полностью откопированные материалы дел могут быть получены ими при выполнении требований ст. 217 УПК РФ. Какую часть дела или все дело копировать - peшает сам защитник. Способы получения им копий: ксерокопирование, фотографирование на цифровой фотоаппарат, реже сканирование.

${ }^{17}$ Обычно электронной папке дают название с указанием номера дела, фамилии обвиняемого, статьи обвинения. 
5. У оперуполномоченного. У него могут остаться копии документов - результатов оперативно-розыскной деятельности, включая их электронные варианты. Иногда оперативные подразделения запрашивают обвинительные заключения и приговоры по делам (в «бумажном» виде) о раскрытых ими преступлениях и/или по которым они осуществляли оперативное сопровождение. Однако получить у них документы - задача не из легких. Слишком строг в соответствующих органах (МВД, ФСКН, ФСБ и др.) режим охраняемой законом тайны.

Совершенно очевидно, что наиболее удобной для использования в практической и учебной деятельности формой получения документов являются электронные копии в редактируемых форматах (Word, RTF, TXТ и т.п.) Не нужно сканировать, а затем распознавать документ. Скачать целую подборку или даже все дело можно за пару секунд из компьютера на флэш-карту, цифровой фотоаппарат и т.п. Главное - получить разрешение от соответствующего практического работника.

Но следует помнить следующее: не всегда легко полученная вами электронная копия документа является окончательной - той, что была подписана и вступила в силу. Иногда в компьютере остается рабочий вариант, а окончательный затерялся или сохранен в другом месте Всегда спрашивайте у автора реального документа, окончательные ли варианты файлов он вам передает.

Давно замечено, что значительная часть студентов-юристов не очень любят искать, читать и анализировать реальные документы. Кому-то это кажется слишком долгим, неинтересным, неэффективным занятием легче прочитать выводы в учебниках, пособиях; кому-то не хочется искать и добиваться предоставления этой информации. К сожалению, часто пренебрежение к процессу изучения практики подспудно прививается отдельными преподавателями и учеными, не имеющими практического опыта и интереса к правоприменительной деятельности как к таковой ${ }^{118}$.

С этой негативной тенденцией нужно бороться всем юридическим вузам, каждому студенту и преподавателю. Ведь активное использование в учебе опубликованной и неопубликованной правоприменительной практики имеет принципиально важное, во многом определяющее значение, поскольку позволяет увидеть и механизмы реализации нормы права, и определенные недоработки, пробелы в законодательстве, и ошибки, нарушения закона, допускаемые правоприменителями.

118 Типичные доводы таких деятелей образования и науки: «грязная работа», «изобилие нарушений закона», «низкий уровень квалификации правоприменителей», «есть смысл нарушений закона», «низкий уровень квалификации правоприменителей», «есть смысл
читать только вступившие в законную силу приговоры, а лучше всего - опубликованную практику Верховного суда РФ. Все остальное - слишком несовершенно» и т.п.
Но главное - работая с данными источниками, студент приобретает незаменимые прикладные навыки, вырабатывает особое практическое чутье, интуицию, учится быстро и глубоко вникать в конкретную правовую проблему, видеть все ее нюансы, в том числе скрытые «между строк», оперативно принимать верные правовые и тактические решения.

Еще раз особое внимание хотелось бы обратить на выбор темы курсовой, дипломной работы. К этому вопросу следует отнестись очень ответственно и творчески. Он во многом может оказаться судьбоносным для студента. Тематика курсовых, как правило, предлагается кафедрой. Она, чаще всего, носит примерный характер. Студент, исходя из своих практических интересов, может по согласованию с преподавателем предложить собственную тему. Это может быть проблема, которая заинтересовала студента на практике или в его работе общественным помощником. Например, вряд ли в тематике курсовых, предлагаемой кафедрой, вы найдете такую как «методика составления постановления о привлечении в качестве обвиняемого: общие правила и особенности региональной практики» ${ }^{119}$. Между тем, актуальность и практическая значимость такой темы очень высока.

Выбор темы работы должен основываться на первичном, в том числе практическом изучении содержания проблемы. Только в этом случае он окажется осознанным, что является важной предпосылкой успеха. Определенная сложность при выборе темы может заключаться в том, что этот выбор и, отчасти, написание работы происходит в процессе усвоения учебной дисциплины, а не по его окончании. В связи с этим студенту целесообразно обратиться за советом к преподавателю и консультанту, которые направят его в нужное русло.

Повторим, очень похвально и результативно, если студент, заинтересовавшись еще на первом или втором курсе какой-либо из научноприкладных проблем, будет углублять ее изучение и исследование на старших курсах, выбирая «сквозную» тематику. В этом случае данная проблема будет изучаться последовательно и всесторонне, в том числе под углом зрения различных юридических дисциплин. Выполненные курсовые работы могут служить хорошей основой для дипломного сочинения, а иногда и диссертации.

Приведем конкретный пример стратегии написания курсовых и квалификационной работы: 119 Имеется в виду практика того региона, в котором живет или учится студент. Региональные
особенности составления тех или иных официальных документов есть и будут всегда. Их необходимо выявлять, анализировать, давать оценку их законности и обоснованности. 
- на первом курсе студент, заинтересовавшись проблемами борьбы с коррупцией, пишет и защищает курсовую работу по теме: «История противодействия коррупции в России»;

- на втором курсе студент, пройдя ознакомительную практику в следственных органах и прокуратуре, и глубоко осознав, насколько актуальна, теоретически и практически значима проблема противодействия коррупции, пишет и защищает курсовую работу по теме: «Специальный субъект коррупционных преступлений». Здесь же он начинает и продолжает все годы обучения деятельность по участию в студенческих конференциях, олимпиадах, конкурсах, грантах, иных научно-исследовательских проектах;

- на третьем курсе студент, пройдя производственную практику в следственном управлении Следственного комитета РФ по субъекту РФ, принимает решение пойти туда работать общественным помощником без отрыва от учебы ${ }^{120}$. Он хочет в будущем стать следователем и по возможности специализироваться ${ }^{121}$ на расследовании преступлений коррупционной направленности. Студент пишет и защищает курсовую работу по теме: «Проблемы квалификации взяточничества и других коррупционных преступлений»;

- на четвертом курсе молодой человек приступает к работе общественным помощником в следственном управлении. Продолжая начатое ранее исследование, он пишет и защищает курсовую работу по теме: «Особенности первоначального этапа расследования взяточничества и других коррупционных преступлений»;

- $\quad$ на пятом курсе студент выходит на преддипломную практику в то же следственное управление. Он отлично зарекомендовал себя в коллективе районного (межрайонного) следственного отдела, а потому имеет веские основания надеяться на то, что по окончании вуза его примут на работу. Тему дипломного сочинения он выбирает уже исходя из наиболее распространенных и актуальных в данном регионе видов уголовных дел о коррупционных преступлениях. Например, тема дипломной работы: «Особенности квалификации и методики расследования взя-

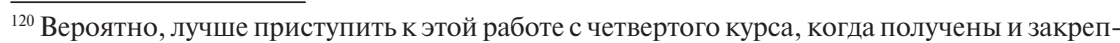
лены базовые знания в таких важных отраслях как уголовное право, гражданское право, уголовный процесс и др. Однако это мнение авторов. Студент должен решить этот вопрос самостоятельно. Можно посоветоваться с родителями, преподавателями, консультантами, руководителем практики.

${ }^{121}$ Как известно, в большинстве следственных подразделений России как таковой специализации следователей формально не существует. Однако фактически она есть, как минимум на уровне правоохранительных органов областного (краевого, республиканского) звена. точничества и других коррупционных преступлений, совершаемых в правоохранительных органах». К тому же он имеет личный опыт работы по таким уголовным делам ${ }^{122}$ и ему эта работа очень интересна. Он опубликовал несколько статей в Интернете, в региональных студенческих и иных научно-прикладных изданиях, выступал на конференциях. Результаты его исследований, как имеющие практическую ценность, внедрены в практику следственных подразделений.

Таким образом, уже к окончанию пятого курса этот студент уже не новичок в следствии. Более того, он и на практическом, и на теоретическом уровне глубоко изучил одну из наиболее актуальных для следственных органов категорий уголовных дел. Поэтому, несмотря на юный возраст и отсутствие трудовой книжки, официального трудового стажа, он является квалифицированным и проверенным молодым специалистом. Именно такой выпускник, а не отличник престижного вуза, будет иметь самые веские конкурентные преимущества при трудоустройстве в следственные органы. Его возьмут на работу, и он с большой степенью вероятности сделает успешную карьеру, специализируясь на расследовании дел обозначенной категории.

Не исключено, что через непродолжительное время после окончания вуза он поступит в аспирантуру и к 25-28 годам защитит кандидатскую диссертацию на тему, созвучную с темой дипломной работы. Далее перед ним открываются еще более широкие перспективы карьеры, профессионального и личностного роста.

Перед нами далеко не гипотетический, а вполне реальный пример успешной профессиональной карьеры юриста. А в основе этого успеха лежит выбор стратегии написания курсовых и дипломной работы; своевременное, еще на втором-третьем курсе вуза, определение профессиональных приоритетов, целеустремленность и трудолюбие.

Очевидно, что приведенный пример написания курсовых и квалификационной работы в сочетании с оптимальными подходами к учебным практикам, есть по сути вариант эффективной профессиональной стратегии молодого юриста. Подобные стратегии могут и должны реализовываться по любой юридической специализации, по любой отрасли и институту права.

\footnotetext{
122 Речь идет об одном из наиболее распространенных в практике СКП РФ видов уголовных дел о коррупции: дела в отношении работников ГИБДД МВД, оперуполномоченных, постовых милиционеров и др.
} 


\section{Приложение 1}

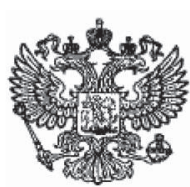

\section{Следственный комитет при прокуратуре}

Российской Федерации

\section{ПРИКАЗ}

15.05 .2008 г

№ 50

г. Москва

\section{Об утверждении Положения об общественном помощнике следователя Следственного комитета при прокуратуре \\ Российской Федерации}

В целях привлечения граждан к работе по противодействию преступности, создания условий для формирования кадрового резерва Следственного комитета при прокуратуре Российской Федерации, руководствуясь п. 13 Положения о Следственном комитете при прокуратуре Российской Федерации, утвержденного Указом Президента Российской Федерации от 01.08.2007 № 1004 «Вопросы Следственного комитета при прокуратуре Российской Федерации»,

\section{ПРИКАЗЫВАЮ:}

1. Утвердить прилагаемые Положение об общественном помощнике следователя Следственного комитета при прокуратуре Российской Федерации (далее - общественный помощник следователя) и образец удостоверения общественного помощника следователя.

2. Главному организационно-инспекторскому управлению Следственного комитета при прокуратуре Российской Федерации (далее - Следственный комитет) совместно с Главным управлением обеспечения деятельности Следственного комитета и управлением кадров Следственного комитета организовать изготовление удостоверений общественного помощника следователя в необходимом количестве.
3. Контроль за исполнением настоящего приказа возложить на заместителей Председателя Следственного комитета при прокуратуре Российской Федерации по направлениям деятельности.

Приказ направить руководителям главных управлений, управлений и отделов центрального аппарата Следственного комитета при прокуратуре Российской Федерации, руководителям следственных управлений Следственного комитета по субъектам Российской Федерации, приравненных к ним специализированных, в числе военных, следственных органов, которых ознакомить с приказом подчиненных работников.

А.И. Бастрыкин, первый заместитель Генерального прокурора

Российской Федерации - Председатель

Следственного комитета при прокуратуре Российской Федерации государственный советник юстиции 1 класса

к приказу первого заместителя Генерального прокурора Российской Федерации Председателя Следственного комитета при прокуратуре Российской Федерации

от 15.05 .2008 № 50

\section{ПОЛОЖЕНИЕ}

об общественном помошнике следователя

\section{Следственного комитета при прокуратуре Российской Федерации}

\section{I. Общие положения}

1. Настоящее Положение устанавливает порядок осуществления деятельности общественного помощника следователя Следственного комитета при прокуратуре Российской Федерации (далее - общественный помощник следователя)

2. Институт общественного помощника следователя призван со- 
действовать привлечению граждан к работе по противодействию преступности, созданию условий для формирования кадрового резерва Следственного комитета при прокуратуре Российской Федерации (далее - Следственный комитет).

3. В своей деятельности общественный помощник следователя руководствуется Конституцией Российской Федерации, законодательством Российской Федерации, нормативными правовыми актами Следственного комитета, настоящим Положением.

\section{II. Организация деятельности общественных} помощников следователей

4. Общественным помощником следователя может быть лицо:

- имеющее гражданство Российской Федерации;

- достигшее возраста 18 лет;

- имеющее образование не ниже среднего;

- в отношении которого не осуществляется (не осуществлялось) уголовное преследование (за исключением случаев прекращения уголовного дела (уголовного преследования) по реабилитирующим основаниям)

- которое не привлекается (не привлекалось) к административной ответственности (в зависимости от конкретных обстоятельств административного правонарушения данный факт может быть признан не являющемся препятствием для назначения лица общественным помощником следователя или основанием для прекращения его полномочий);

- годное по состоянию здоровья, моральным и деловым качествам к осушествлению деятельности в качестве общественного помощника следователя, имеющее склонность к следственной работе

5. Работа по подбору кандидатов в общественные помощники следователей организуется руководителями следственных управлений Следственного комитета по субъектам Российской Федерации и приравненных к ним специализированных следственных управлений (отделов) Следственного комитета, в том числе военных следственных управлений Следственного комитета по военным округам, флотам, ракетным войскам стратегического назначения и других военных следственных управлений Следственного комитета, приравненных к следственным управлениям по субъектам Российской Федерации (далее - следственное управление), следственных отделов по районам городам и приравненных к ним специализированных следственных отделов Следственного комитета, в том числе военных следственных отделов Следственного комитета по объединениям, соединениям, гар- низонам и других военных следственных отделов Следственного комитета, приравненных к следственным отделам Следственного комитета по районам, городам (далее - следственный отдел).

6. Необходимый и достаточный количественный состав общественных помощников следователей определяется соответствующим руководителем следственного органа для конкретного следственного управления, следственного отдела и их структурных подразделений в пределах установленных полномочий.

7. Для решения вопроса о назначении лица общественным помощником следователя и кадровое подразделение следственного управления предъявляются:

- рапорт следователя о согласии с назначением лица общественным помощником следователя, завизированный руководителем следственного отдела, руководителем структурного подразделения следственного управления;

- личное заявление кандидата в общественные помощники следователя на имя руководителя соответствующего следственного органа;

- справка - объективка;

- личный листок по учету обшественных помощников следователя установленного образца (заверяется работником кадрового подразделения или соответствующим работником следственного отдела, на которого возложены обязанности формирования документов кандидата в общественные помощники следователей);

- автобиография;

- копия паспорта гражданина Российской Федерации;

- копия военного билета или приписного свидетельства с необходимыми отметками;

- заверенные в установленном порядке копия диплома или свидетельства об образовании либо справка из учебного заведения с указанием курса обучения, формы и даты окончания;

- копия трудовой книжки;

- характеристика с последнего места работы или учебы;

- две фотографии установленного образца;

- медицинское заключение о состоянии здоровья (форма № 086y, справки из психоневрологического и наркологического диспансера);

- выписки из финансово-лицевого счета и домовой книги, подтверждающие факт проживания (регистрации) общественного помощника следователя на территории деятельности следственного органа.

8. При поступлении указанных документов в кадровое подразделение следственного управления его работниками проводится дополнительная 
проверка сведений о кандидате в общественные помощники следователя, а при необходимости о его ближайших родственниках, в том числе сведений о судимости и привлечении лица к административной ответственности.

9. После завершения проверки в отношении кандидата в общественные помощники следователя кадровым подразделением готовится заключение о возможности или невозможности использования лица в качестве общественного помощника следователя.

10. В отношении общественного помощника следователя, деятельность которого будет осуществляться в соответствующем следственном отделе, необходимые документы и материалы кадровое подразделение направляет руководителю указанного следственного органа.

11. Общественный помошник следователя приступает к исполнению обязанностей на основании приказа руководителя следственного органа, в котором непосредственно будет осуществлять свою деятельность обшественный помошник следователя.

12. В приказе о назначении следователю общественного помощника должны быть определены:

- срок полномочий общественного помощника следователя, который не может превышать двух лет;

- следователь, на которого возложено руководство работой общественного помощника следователя и контроль за его деятельностью, а также персональная ответственность за соответствие его действий законодательству Российской Федерации.

13. Общественному помощнику следователя выдается удостоверение установленного образца на предусмотренный приказом срок полномочий, дающее право беспрепятственного прохода при предъявлении удостоверения в здания следственного органа, в котором осушествляется деятельность общественного помощника следователя, а в здания Следственного комитета при прокуратуре Российской Федерации и иных следственных органов при выполнении поручения следователя - по разовому пропуску.

14. Учет общественных помощников следователя, оформление, выдача и учет удостоверений общественного помощника следователя осуществляется кадровым подразделением следственного органа.

15. Полномочия общественного помощника следователя прекращаются приказом руководителя следственного органа, в котором осуществлялась деятельность общественного помощника следователя:

- в связи с истечением срока полномочий общественного помощника следователя;

- по просьбе общественного помощника следователя;
- по инициативе руководителя следственного органа;

- по рапорту следователя следственного органа о ненадлежащем исполнении возложенных настоящим Положением на обшественного помощника следователя обязанностей либо злоупотреблении правами, предоставленными настоящим Положением.

16. В связи с прекращением полномочий общественного помощника следователя его удостоверение в день прекращения полномочии подлежит возврату в следственный орган, в котором осуществлялась деятельность общественного помощника следователя.

\section{III. Права и обязанности общественного помощника следователя}

17. Общественный помощник следователя осуществляет свою деятельность на общественных началах, безвозмездной основе, принципах законности, соблюдения прав и свобод человека и гражданина.

18. Общественный помощник следователя:

- оказывает техническую, информационную и организационную помощь следователю в его работе;

- готовит в соответствии с поручением следователя проекты документов.

19. Общественный помощник следователя обязан оперативно информировать следователя и руководителя следственного органа о проблемах, возникающих при осуществлении им своих полномочий, в том числе о привлечении к уголовной или административной ответственности либо иных обстоятельствах, препятствующих исполнению полномочий общественного помощника следователя.

20. Общественный помощник следователя несет ответственность за достоверность предоставленной информации, качество и своевременность выполнения обязанностей, возложенных на него настоящим Положением, а также ущерб, причиненный в результате его неправомерных действий следственному органу либо правам и законным интересам граждан и организаций.

21. Общественный помощник следователя ежеквартально к 10 числу месяца, следуюшего за истекшим кварталом, готовит письменную информацию о проделанной работе, которая согласовывается со следователем и утверждается руководителем следственного органа, в котором осуществляется деятельность общественного помощника следователя.

22. Не допускается привлечение общественного помощника следователя в качестве участника уголовного судопроизводства (эксперта, специалиста, переводчика, понятого). 
23. Общественный помощник следователя не может быть допущен к работе с документами, содержащими государственную тайну и служебную информацию ограниченного пользования, ему запрещается разглашать сведения, ставшие известными в процессе выполнения поручений следователя по уголовному делу.

24. Общественному помощнику следователя запрещаемся лично или через других лиц получать от физических и юридических лиц какое-либо вознаграждение (денежные средства, подарки, услуги, оплата развлечений, отдыха, транспортных расходов и прочее) в связи с исполнением обязанностей общественного помощника следователя, а также использовать полномочия общественного помощника следователя в личных целях.

\section{IV. Координация деятельности общественных помощников следователей}

25. Контроль за деятельностью общественного помощника следователя осуществляет следователь, который согласно приказу руководит его работой.

26. Координацию работы общественных помощников следователей, закрепленных за несколькими следователями, осуществляет руководитель следственного органа, в котором осуществляется деятельность указанных общественных помощников следователя

27. Руководитель следственного органа и следователь обязаны обучать общественных помощников следователей основам уголовного и уголовнопроцессуального законодательства, а также теории и практике следственной работы, не реже одного раза в квартал проводить совещания по подведению итогов деятельности обшественных помощников следователя.

28. По представлению руководителя следственного органа общественный помощник следователя может быть зачислен в кадровый резерв для приема на службу (работу) в Следственный комитет при прокуратуре Российской Федерации.

V. Порядок оформления, выдачи и учета удостоверений общественного помошника следователя

29. Удостоверение общественного помощника следователя вручается лично общественному помощнику следователя под расписку в книге учета удостоверений.

30. О факте утраты удостоверения общественный помощник следователя обязан незамедлительно в письменной форме сообщить руководителю следственного органа.
31. Удостоверение общественного помощника следователя после его возвращения в следственный орган в связи с прекращением полномочий общественного помощника следователя подлежит погашению и уничтожению по акту с отметкой в книге учета удостоверений.

32. Учет, хранение и уничтожение удостоверении общественного помощника следователя устанавливается в порядке, аналогичном порядку, определенному приказом первого заместителя Генерального прокурора Российской Федерации - Председателя Следственного комитета при прокуратуре Российской Федерации от 02.10.2007 № 24 «Об утверждении Инструкции о порядке оформления, учета и выдачи служебных удостоверений работникам органов и учреждений Следственного комитета при прокуратуре Российской Федерации».

VI. Иные вопросы организации работы по подбору кандидатов в общественные помощники следователя и оформлению необходимых документов, а также обеспечения деятельности общественного помощника следователя

33. Образны документов, необходимых для оформления кандидата в общественные помощники следователя и ведения его личного дела, также определяются управлением кадров Следственного комитета.

34. Конкретный порядок оформления и проверки кандидатов в общественные помощники следователя, контроль их деятельности в период исполнения полномочий, а также иные вопросы, связанные с подбором и назначением общественного помощника следователя, устанавливаются управлением кадров Следственного комитета путем издания соответствующего организационно-распорядительного документа. 
к приказу первого заместителя

Генерального прокурора

Российской Федерации

Председателя Следственного

комитета при прокуратуре

Российской Федерации

от 15.05 .2008

\section{ОБРАЗЕЦ}

удостоверения общественного помощника следователя

\section{I. Описание удостоверения}

1. Удостоверение представляет собой книжечку в переплете из кожзаменителя красного цвета размером (в развернутом состоянии) 195 х 65 мм с надписью на лицевой стороне по центру прописными буквами «УДОСТОВЕРЕНИЕ». ВЫклейки удостоверения белого цвета.

2. На левой выклейке удостоверения слева наклеивается фотография владельца удостоверения размером 3,5 x 4,5 мм, на правый нижний угол которой ставится печать следственного органа, в котором осуществляется деятельность общественного помощника следователя, при этом часть оттиска печати должна размещаться на выклейке, справа от фотографии (внизу) расположены слова: «Подпись владельца» с чертой для подписи.

3. На правой выклейке удостоверения вверху располагается текст, содержащий наименование следственного органа, в структурном подразделении которого осуществляется деятельность общественного помощника следователя: «Следственный комитет при прокуратуре Российской Федерации» либо «Следственное управление Следственного комитета при прокуратуре Российской Федерации» (и субъектах Российской Федерации), ниже слова «УДОСТОВЕРЕНИЕ № », под ними через интервал в 5 мм печатается «Выдано», после которого должны указываться фамилия, имя, отчество владельца удостоверения, еще ниже печатаются слова: «в том, что он (а) является общественным помощником следователя в» (далее указывается следственный орган, в котором осушествляется деятельность общественного помощника следователя), ниже располагается текст «Действительно по », внизу располагается подпись руководителя следственного органа, в котором осуществляется деятельность общественного помощника следователя.

II. Графическое изображение удостоверения
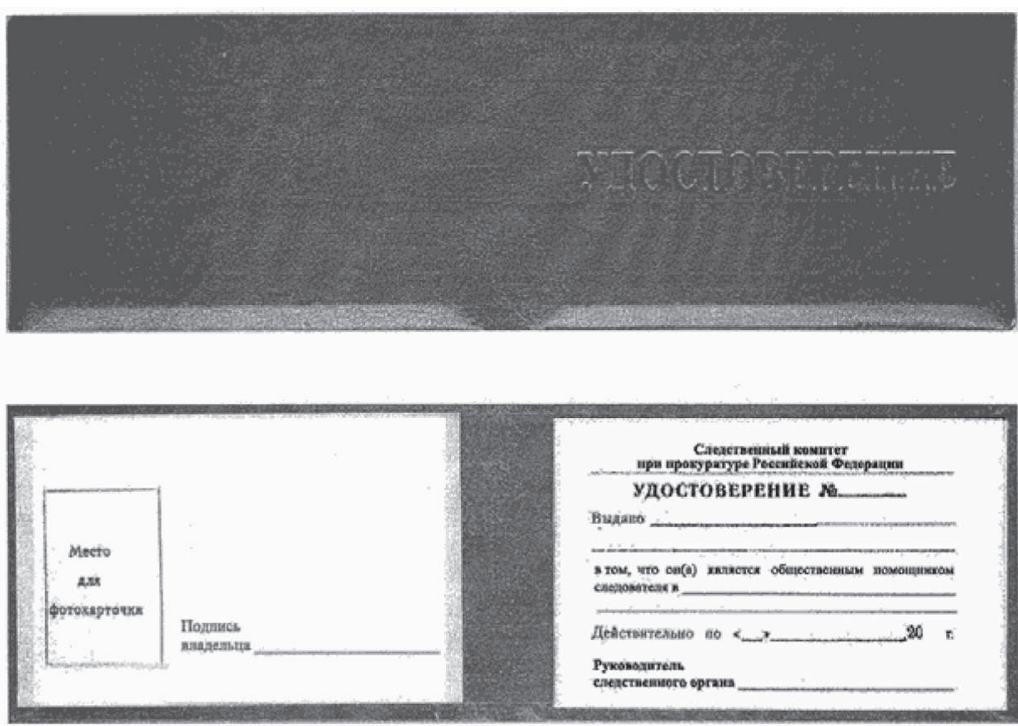


\section{Приложение 2}

Образец постановления о привлечении в качестве обвиняемого (ч. 2 ст. 290 и ч. 1 ст. 286 УК РФ)*

\section{ПОСТАНОВЛЕНИЕ ${ }^{123}$}

о привлечении в качестве обвиняемого

22 апреля 2009 года

Старший следователь следственного отдела района СУ СК при прокуратуре РФ по рассмотрев материалы уголовного дела №

\section{УСТАНОВИЛ:}

По настоящему уголовному делу собраны достаточные доказательства, дающие основания для предъявления обвинения гр. Г. в том, что он, являясь должностным лицом - директором муниципального общеобразовательного учреждения (МОУ) «Автошкола» г. __, назначенный на эту должность первым заместителем начальника департамента образования, науки и молодежной политики___ приказом №___ от 21.07.2008, совершил умышленные преступления при следующих обстоятельствах

Гр. Г. в соответствии с должностной инструкцией, утвержденной председателем комитета образования администрации г.

01.09.2007 осуществлял организационно-распорядительные функции, то есть в его обязанности входило руководство учреждением в соответствии с его Уставом, в том числе он нес ответственность за реализацию образовательных программ в соответствии с учебным планом и графиком учебного процесса; за качество образования выпускников; соблюдение прав и свобод обучающихся (воспитанников) и работников учреждения во время образовательного процесса в установленном законодательством РФ порядке; а также ${ }^{124}$

Гр. М., зная, что МОУ «Автошкола» проводит курсы по подготовке водителей различных категорий, решил, не проходя обучение, получить свидетельство об окончании курсов водителей категории «С». С этой целью 20.02.2009 примерно в 14.00, в кабинете № 3 МОУ по адpecy он обратился с просьбой к директору МОУ «Автошкола»

\footnotetext{
${ }_{123}$ Все наименования и инициалы вымышлены, совпадения случайны
}

124 Здесь при необходимости следует перечислить и другие обязанности должностного лица, нарушение которых входит в содержание предъявляемого ему обвинения. гр. Г., который, как руководитель учреждения, был наделен служебными полномочиями по выдаче свидетельств об окончании курсов лицам, прошедшим обучение. М. просил Г. выдать ему свидетельство об окончании курсов водителей категории «С».

Гр. Г., зная, что гр. М. не проходил соответствующие курсы, предложил последнему заплатить за указанное свидетельство 1500 рублей. Гр. М. согласился и в этот же день, в период между 17.00 и 18.00, гр. Г. в своем кабинете по адресу умышленно, из корыстных побуждений, с целью личного обогашения, желая получить взятку, действуя вопреки интересам службы, осознавая, что совершает незаконные действия в интересах гр. М., получил от него 1500 рублей, 15-ю купюрами по 100 рублей, за выдачу ему свидетельства серии _№____ о прохождении в МОУ «Автошкола» курсов по примерной программе подготовки (переподготовки) водителей транспортных средств категории «С».

В соответствии с упомянутой должностной инструкцией от 01.09.2007, а также п. __ Правил _ _ гр. Г. как должностное лицо вправе был выдать гр. М. свидетельство об окончании курсов водителей только в случае выполнения им всех требований в рамках учебного процесса, успешной сдачи экзаменов, а так же $\mathrm{e}^{125}$ . Явно для себя нарушая эти требования, гр. Г. тем самым осознавал, что получает взятку за незаконные действия.

Этими действиями гр. Г. совершил преступление, предусмотренное ч. $2 \mathrm{~cm} .290$ УК РФ - получение долэнностным лицом лично взятки в виде денег - за действия в пользу взяткодателя, если такие действия входят в служебные полномочия должностного лица - за незаконные действия.

При описанных выше обстоятельствах гр. Г. 20.02.2009 в период между 17.00 и 18.00 в кабинете № 3 МОУ по адресу ___ _ зная, что гр. М. не проходил курсы по подготовке водителей категории «С», желая получить взятку за заведомо незаконные действия в пользу гр. М., предложил гр. М. заплатить за свидетельство об окончании курсов водителей категории «С» 1500 рублей.

В соответствии с упомянутой должностной инструкцией от 01.09.2007, а также п. Правил , гр. Г. как должностное лицо вправе был выдать гр. М. свидетельство об окончании курсов водителей только в случае выполнения им всех требований в рамках учебного процесса, успешной сдачи экзаменов, а также Явно для себя нарушая эти требования, гр. Г. в этот же день, в период между 17.00 и

125 Здесь при необходимости следует перечислить и другие обязательные требования, при выполнении которых выдается свидетельство, например, оплата стоимости обучения и др. Нарушение этих требований указывает на признаки вменяемых составов преступлений, в частности, на ч. 2 ст. 290 УК РФ. 
18.00 в своем кабинете по адресу , умышленно действуя из корыстных побуждений, получил взятку в размере 1500 рублей от гр. М за незаконную выдачу ему свидетельства.

После этого Г. обратился к секретарю МОУ «Автошкола» гр-ке С., и как ее руководитель дал указание принести незаполненное свидетельство серии № о прохождении в МОУ «Автошкола» курсов по примерной программе подготовки (переподготовки) водителей транспортных средств категории «С». Здесь же в присутствии М., гр. Г. заполнил необходимые данные в этом официальном документе, предоставляющем право и выдал подложный документ гр. М.

Совершая эти действия вопреки интересам службы из корыстной заинтересованности, гр. Г. явно для себя выходил за пределы своей служебной компетенции. При этом он осознавал, что допускает противозаконные действия, которые он был вправе совершить только при наличии особых обстоятельств, указанных в названных нормативно-правовых актах. Незаконные действия гр. Г. повлекли существенные нарушения прав и законных интересов граждан, организаций (МОУ «Автошкола» и других) и охраняемых законом интересов общества и государства.

Существенные нарушения выразились, во-первых, в подрыве в глазах граждан авторитета не только МОУ, но и иных организаций, уполномоченных обеспечить законную и обоснованную выдачу документов о праве управления транспортными средствами; во-вторых, в причинении материального вреда в виде упушенной МОУ «Автошкола» выгоды (cmoимость обучения на сумму 6800 рублей); в-третьих, в создании условий для причинения вреда охраняемым законом интересам граждан, общества и государства, заинтересованных в том, чтобы транспортным средством - источником повышенной опасности, управлял только гражданин, имеющий необходимые знания и навыки. При отсутствии таковых, М. создает реальную угрозу, в том числе жизни и здоровью людей. Эти существенные по своему содержанию нарушения находятся в причинной связи с описанными действиями Г. и охватывались его умыслом.

Этими действиями гр. Г. совершил преступление, предусмотренное ч. 1 cm. 286 УК РФ - превышение должностных полномочий, то есть совершение должностным лицом действий, явно выходящих за пределы его полномочий и повлекших существенное нарушение прав и законных интересов граждан и организаций, а также охраняемых законом интересов общества и государства.

На основании изложенного и руководствуясь ст. 171 и 172 УПК РФ,

\section{ПОСТАНОВИЛ:}

\section{ОТВЕТЫ НА ТИПИЧНЫЕ ВОПРОСЫ}

\section{ПО СОСТАВЛЕНИЮ ОБВИНЕНИЯ}

Вопрос 1. Почему гр. Г. предбявлено обвинение по двум статьям - ч. 2 cm. 290 и ч. 1 cm. 286 УК РФ, а не только в получении взятки? Разве получение взятки за незаконные действия не охватывают признаки превышения должностных полномочий?

Oтвет. Вопрос типичный по делам данной категории, а ответ на него носит дискуссионный характер. Прежде всего отметим, что пример отражает универсальную и распространенную «обвинительную» позицию126: при наличии законных оснований лучше вменить больше эпизодов/составов преступлений, притом более тяжких, чтобы тем самым обеспечить стороне обвинения максимальные гарантии победы в состязательном процессе.

Не будем вступать в подробную дискуссию по вопросу квалификации. Отметим лишь, что данная позиция имеет законные основания. Так, Пленум Верховного суда РФ в п. 19 постановления № 6 от 10.02.2000 г. отметил, что ответственность за дачу и получение взятки или коммерческий подкуп не исключает одновременного привлечения к уголовной ответственности за действия, образующие самостоятельное преступление. В таких случаях содеянное подлежит квалификации по совокупности преступлений.

Получение взятки по конструкции состав формальный, считается оконченным с момента передачи хотя бы части взятки. Превышение полномочий - состав материальный. С учетом ч. 2 ст. 9 УК РФ это преступление считается оконченным в момент совершения действий, явно выходящих за пределы полномочий (выдача гр-ном Г. свидетельства). В объективную сторону включены преступные последствия - «существенное нарушение прав и законных интересов...» Таким образом, получение взятки не может поглощать превышение полномочий, поскольку не охватывает всех его признаков.

\footnotetext{
126 Просим не путать с обвинительным уклоном! Обвинительная позиция - это всегда позиция, основанная на законе, пусть даже использующая его диспозитивность, неопределенность, пробелы. Она включает и обязанность органа расследования собирать и исследовать все доказательства, опровергающие версию обвинения (ч. 2 ст. 14 УПК РФ). Обвинительный же уклон - это игнорирование сведений, свидетельствующих о невиновности либо о меньшей степени ответственности обвиняемого, неадекватная ценка собранных доказательств и т.п. Другими словами, обвинительный уклон является проявлением ненадлежащего выполнения функции обвинения соответствующими участниками процесса.
} 
Вопрос 2. Почему гр. Г. предбявлено обвинение по ч. 1 cm. 286 УК РФ, а не по ч. $1 \mathrm{~cm} .285$ УК РФ?

Ответ. Наш образец документа вновь отражает логику «обвинительной» позиции: при наличии законных оснований лучше вменить такие составы преступлений, которые с большей гарантией «устоят» в суде.

Дело в том, что в практике часто уголовные дела по обвинению должностных лиц по совокупности преступлений, предусмотренных ст.ст. 290 и 285 УК РФ, полностью «разваливается» ввиду того, что, не доказав получение взятки ${ }^{127}$, обвинение лишается и корыстного мотива должностного злоупотребления как обязательного признака этого состава. В ст. 286 УК РФ этого признака нет. Именно поэтому опытные практические работники, при наличии законных оснований, ищут доказательства признаков превышения должностных полномочий, а не злоупотребления ${ }^{128}$. Тем более что другие различия между этими составами не так существенны и весьма оценочны.

Вопрос 3. Почему одни и те же по своему содержанию фактические обстоятельства, подпадающие под признаки ч. 2 cm. 290 УК РФ и ч. 1 cm. 286 УК РФ, «расписаны» в тексте дважды? Нельзя ли было все описать один раз, без повторов?

Oтвет. Дело в том, что в соответствии с требованиями ч. 3 ст. 171 УПК РФ при обвинении лица в совершении нескольких преступлений, предусмотренных разными пунктами, частями, статьями УК РФ, в обвинении должно быть указано, какие деяния вменяются ему по каждой из этих норм уголовного закона. То есть обвинение должно быть изложено в тексте документа по следующей схеме:

«содержание обвинения по эпизоду № $1-$ формула и формулировка обвинения № 1»; «содержание обвинения по эпизоду № $2-$ формула и формулировка обвинения № 2 и т.д.». Действительно, когда обвинение содержит реальную или идеальную совокупность преступлений (ч.ч. 1-2 ст. 17 УК РФ), как то имеет место в нашем случае ${ }^{129}$, такая

127 Это часто происходит по формальным основаниям, например, в результате признания недопустимыми вполне достоверных доказательств, сформированных на основе результатов ОРД (акт оперативного эксперимента, аудиозаписи, изъятые помеченные деньги и т.п.).

${ }^{128}$ Об отличиях злоупотребления и превышения должностных полномочий см., например, п. 11 Постановления Пленума Верховного суда СССР № 4 от 30 марта 1990 г. «О судебной практике по делам о злоупотреблении властью или служебным положением, превышении власти или служебных полномочий, халатности и должностном подлоге» (с изменениями от 10 февраля 2000 г.).

${ }^{129}$ В обвинении гр. Г. имеет место реальная совокупность. схема изложения приводит к повторам некоторых фактических обстоятельств в тексте. В определенной мере это допустимо.

Но и полностью копировать текст нельзя ни в коем случае. В обвинении гр. Г. фактические обстоятельства получения взятки и превышения полномочий совпадают далеко не полностью. В первом эпизоде следователь акцентирует внимание на обстоятельствах передачи предмета взятки, умысле виновного на ее получение и на том, за какие действия она передается. Во втором эпизоде акценты смешаются. Следователь вновь, но как бы вскользь упоминает о передаче взятки, а больше внимания уделяет тому, как и при каких обстоятельствах гр. Г. явно для себя выходит за пределы конкретных служебных полномочий, а затем обстоятельно описывает существенные нарушения, то есть преступные последствия, предусмотренные диспозицией ч. 1 ст. 286 УК РФ.

Вопрос 3. Кстати, а действительно, почему так подробно следователь «расписал» преступные последствия? Почему этому посвящены два завершающих и таких больших по объему абзаца текста?

Ответ. Следователь хорошо знаком с судебной практикой по подобным делам. Ему известно, что суды часто с большой неохотой принимают решение о признании подсудимого виновным по совокупности преступлений (см. ответ на вопрос 1). Одним из важных и сложных в доказывании признаков превышения должностных полномочий является признак преступных последствий - «существенных нарушений...», а они носят оценочный характер. Оценочный - значит требующий тщательного, творческого подхода в описании.

Кто же по вашему должен доказывать и подробно «расписывать» оценочные признаки, причем любые, в любом составе преступления? Судьи? Нет! Они вообее не любят, да и не обязаны сами находить и описывать какие-либо оценочные признаки. Инициатива, в виде формулировки соответствующих текстов, должна исходить со стороны обвинения. В этом ей призвано помочь упомянутое в сноске постановление Пленума Верховного суда СССР от 30 марта 1990 г. № 4. Берем этот текст и раскрываем его применительно к обстоятельствам дела гр-на Г. Повторим, если следователь не «распишет» эти оценочные последствия в обвинении - судья вряд ли сделает это в приговоре. Ему будет проще оправдать подсудимого в этой части.

Вопрос 4. Почему в обвинении «расписаны» признаки, которые не входят в конструкиию составов преступлений, предусмотренных ч. 2 cm. 290 и ч. $1 \mathrm{~cm} .286$ УК РФ? Например, имеются такие фразы, как: 1) «официальный документ, предоставляюший право ...», 2) «подложный документ», 3) «...из корыстной заинтересованности». Зачем писать лишнее? 
Ответ. Ничего лишнего в обвинении нет. Действительно, следователь намеренно внес в содержание обвинения эти признаки, поскольку все три являются обязательными для состава служебного подлога (ч. 1 ст. 292 УК РФ), а третий - для состава злоупотребления должностными полномочиями (ч. 1 ст. 285 УК РФ). Опытный субъект-обвинитель знает о правовых основаниях и порядке изменения обвинения (ст. 252 УПК РФ, ч. 8 ст. 246 УПК РФ). Размышляя о судебной перспективе по делу, следователь, руководитель следственного органа совместно моделируют, в том числе и варианты неблагоприятного для стороны обвинения хода судебного разбирательства:

- например, как это часто бывает, в суде может «не устоять» эпизод получения взятки. Ничего страшного - остается ч. 1 ст. 286 УК РФ Это все-таки лучше, чем полное поражение - оправдательный приговор по всему объему обвинения;

- суд может признать недоказанным не только ч. 2 ст. 290 УК РФ, но и ч. 1 ст. 286 УК РФ. В частности, судья может не согласиться с критерием сушественности «нарушения...» как преступного последствия превышения полномочий (см. ответ на вопрос 3. Очень неприятно для стороны обвинения, но тоже «не смертельно». Государственный обвинитель может предложить замену квалификации с ч. 1 ст. 286 УК РФ на на ч. 1 ст. 292 УК РФ - служебный подлог. А такое, как и любое другое, изменение обвинения допустимо только, если действия подсудимого, квалифицируемые по новой статье закона, вменялись ему в вину и существенно не отличаются по фактическим обстоятельствам от обвинения, по которому дело принято к производству суда.

Вот и получается, что следователю, в порядке своеобразной страховки, полезно «расписать» необходимые признаки ч. 1 ст. 292 УК РФ, но не включать этот состав в объем обвинения.

Вот такая странная и противоречивая лишь, на первый взгляд, логика интересов стороны обвинения. Еше раз подчеркнем - она, на наш взгляд, не противоречит законодательству, но использует его пробельность или диспозитивность в состязательных интересах.

\section{Оглавление}

Предисловие.

Глава 1. КОМУ И КАК ПОЛЬЗОВАТЬСЯ

ЭТИМ РУКОВОДСТВОМ

1.1. Обращение к следователям и руководителям

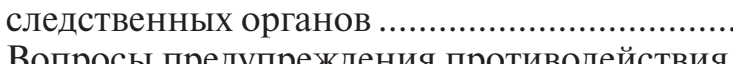

1.2. Вопросы предупреждения противодействия и сохранения тайны предварительного расследования ..... 9

1.3. Обращение к общественным помощникам и практикантам...

1.4. Где скачать и как работать с электронными приложениями.

Глава 2. КАК ПОМОЧЬ ПРАВИЛЬНО СИСТЕМАТИЗИРОВАТЬ И «ПОДШИТЬ» ДЕЛО

2.1. Систематизация несложного уголовного дела в отношении одного обвиняемого............................... 16

2.2. Систематизация многотомных и многоэпизодных

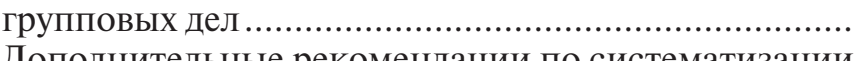

2.3. Дополнительные рекомендации по систематизации и подшивке материалов уголовных дел

Глава 3. ПАПКА ДЛЯ БУМАГ «ВЫЕЗДНАЯ» И ПРОЧИЕ ДЕТАЛИ 24

ГЛава 4. ПРОВЕДЕНИЕ ДОСЛЕДСТВЕННОЙ ПРОВЕРКИ, СИСТЕМАТИЗАЩИЯ МАТЕРИАЛОВ 29

ГЛава 5. ОБЩЕСТВЕННЫЕ ПОМОЩНИКИ И ПРАКТИКАНТЫ КАК ПОНЯТЫЕ И СПЕЦИАЛИСТЫ: ЗА И ПРОТИВ 37

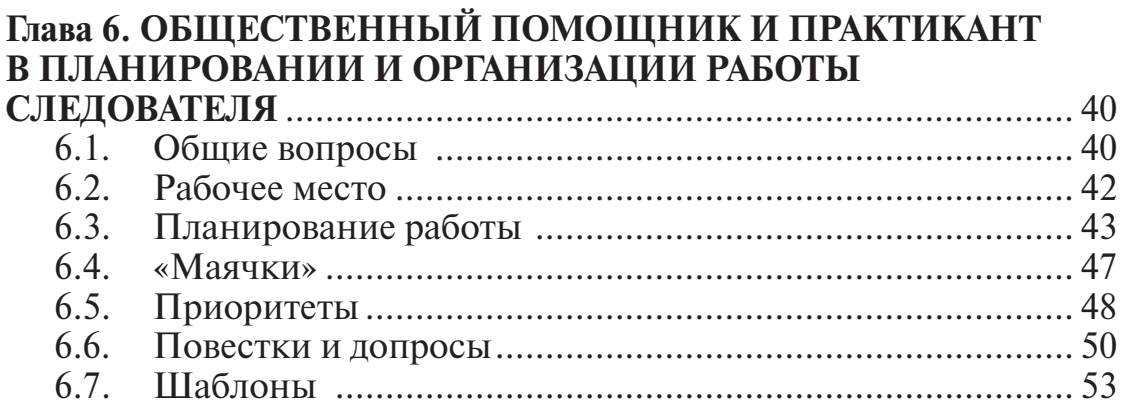


ГЛава 7. РАБОТА НА МЕСТЕ ПРОИСШЕСТВИЯ ................... 54

7.1. Составление «памятки-бегунка» и пометка «вешдоков» ... 54

7.2. Особенности фотосъемки места происшествия .............. 57

7.3. Работа со следами различного происхождения …........6 62

7.4. Обнаружение, фиксация и изъятие следов рук .............. 64

7.5. Обнаружение, фиксация и изъятие следов ног................ 71

7.6. Особенности фиксации и изъятия объектов

биологического происхождения ............................... 78

7.7. Работа со запаховыми следами (одорологические следы) ... 81

Глава 8. ЕСЛИ СЛЕДОВАТЕЛЬ «НА ВЫ» С КОМПЫЮТЕРОМ:

СОВЕТЫ ОПЫТНОГО ЮЗЕРА

ГЛава 9. СОСТАВЛЕНИЕ ОТДЕЛЬНЫХ

ПРОЦЕССУАЛЬНЫХ ДОКУМЕНТОВ

Глава 10. ОСОБЕННОСТИ ДОПРОСА

ГЛава 11. ОСОБЕННОСТИ ПРЕДЪЯВЛЕНИЯ

ДЛЯ ОПОЗНАНИЯ

ГЛава 12. ОСОБЕННОСТИ ПРОВЕРКИ ПОКАЗАНИЙ

HA MECTE .

ГЛава 13. ОСОБЕННОСТИ ОСМОТРА ВЕЩЕСТВЕННЫХ

ДОКАЗАТЕЛЬСТВ

ГЛава 14. КАК ПОМОЧЬ СОСТАВИТЬ ПОСТАНОВЛЕНИЕ

О ПРИВЛЕЧЕНИИ В КАЧЕСТВЕ ОБВИНЯЕМОГО

ГЛава 15. КАК ПОМОЧЬ В ПРОВЕРКЕ МАТЕРИАЛОВ

УГОЛОВНОГО ДЕЛА

Глава 16. УЧЕБНАЯ ПРАКТИКА СТУДЕНТА, КУРСОВЫЕ, ДИПЛОМНАЯ РАБОТА КАК ЭТАПЫ ПРОФЕССИОНАЛЬНОЙ СТРАТЕГИИ УСПЕШНОГО ЮРИСТА

(вместо Послесловия) ..

Приложение 1.

Приложение 2 .

\section{Коллектив авторов}

Артур Викторович Бычков - директор Юридического института Сибирской академии права, экономики и управления (г. Иркутск), кандидат юридических наук, доцент - глава 16 (в соавторстве с Ю.П. Гармаевым).

Юрий Петрович Гармаев - доктор юридических наук - глава 1, главы 3, 6 и 8 (в соавторстве с Э.В. Мартиросяном), глава 5 (в соавторстве с Т. Т. Магомедовым), глава 14 и Приложение 2 (в соавторстве с И.И. Телегиным), глава 15 (в соавторстве с А.О. Хориноевым), глава 16 (в соавторстве с А.В. Бычковым).

Светлана Викторовна Корнакова - заместитель декана судебно-следственного факультета, доцент кафедры уголовного процесса и криминалистики Байкальского государственного университета экономики и права (г. Иркутск), кандидат юридических наук - глава 10.

Tимур Талехович Магомедов - заместитель Восточно-Байкальского межрайонного природоохранного прокурора, советник юстиции - глава 2 (в соавторстве с Э.В. Мартиросяном), глава 4 (в соавторстве с Р. А. Мартыновым), глава 5 (в соавторстве с Ю.П. Гармаевым), глава 9.

Энок Возгенович Мартиросян - прокурор-криминалист отдела криминалистики следственного управления Следственного комитета при прокуратуре РФ по Тюменской области, старший советник юстиции - глава 2 (в соавторстве с Т.Т. Магомедовым), главы 3 и 6 (в соавторстве с Ю.П. Гармаевым), глава 7.1, глава 8 (в соавторстве с Ю.П. Гармаевым)

Роман Александрович Мартынов - судья Октябрьского районного суда г. Улан-Удэ (Республика Бурятия) - глава 4 (в соавторстве с Т.Т. Магомедовым), глава 12

Владислав Олегович Пантелеев - следователь группы по расследованию преступлений, совершенных против личности, и бандитизма при отделе по расследованию особо важных дел следственного управления Следственного комитета при прокуратуре РФ по Новосибирской области, юрист 2 класса - глава 13.

Диана Аркадьевна Степаненко - профессор кафедры уголовно-правовых дисциплин Восточно-Сибирского филиала Российской академии правосудия (г. Иркутск), доктор юридических наук, профессор - глава 11.

Игорь Иванович Телегин - руководитель следственного управления Следственного комитета при прокуратуре РФ по Новосибирской области, государственный советник юстиции 3 класса, почетный работник прокуратуры РФ глава 14 и Приложение 2 (в соавторстве с Ю.П. Гармаевым).

Анатолий Орхокович Хориноев - председатель Верховного суда Республики Бурятия, кандидат юридических наук, Заслуженный юрист РФ - Предисловие, глава 15 (в соавторстве с Ю.П. Гармаевым).

Дмитрий Юрьевич Яковлев - заведуюший кафедрой уголовно-правовых дисциплин Юридического института Сибирской академии права (г. Иркутск), экономики и управления, кандидат юридических наук, доцент - главы 7.2-7.7. 
РУКОВОДСТВО ДЛЯ СЛЕДОВАТЕЛЯ И ЕГО ПОМОЩНИКА, ПРАКТИКАНТА

Учебно-практическое пособие

Руководитель авторского коллектива и ответственный редактор доктор юридических наук Ю.П. Гармаев

Выпускающий редактор Киреева Е.В.

Лицензия ЛР № 066272 от 14 января 1999 г.

Сдано в набор 16.10.2009. Подписано в печать ХХ.ХХ.2009.

Формат 60Х88/16. Бумага офсетная. Усл. печ. л. 13.

Тираж 3000 экз. (1-й завод - 1000 экз.) Заказ №

ООО Издательство «Юрлитинформ»

119019, г. Москва, ул. Волхонка, д. 6.

Отпечатано в ОАО «12 ЦТ»

119019, г. Москва, Староваганьковский пер., д. 17

Тел.: 697-73-48 